\title{
From Peasant to Pariah: Changing English Perceptions of the Irish from the 1820s Through the 1860s
}

Traci J. Scully

West Virginia University

Follow this and additional works at: https://researchrepository.wvu.edu/etd

\section{Recommended Citation}

Scully, Traci J., "From Peasant to Pariah: Changing English Perceptions of the Irish from the 1820s

Through the 1860s" (2011). Graduate Theses, Dissertations, and Problem Reports. 3462.

https://researchrepository.wvu.edu/etd/3462

This Dissertation is protected by copyright and/or related rights. It has been brought to you by the The Research Repository @ WVU with permission from the rights-holder(s). You are free to use this Dissertation in any way that is permitted by the copyright and related rights legislation that applies to your use. For other uses you must obtain permission from the rights-holder(s) directly, unless additional rights are indicated by a Creative Commons license in the record and/ or on the work itself. This Dissertation has been accepted for inclusion in WVU Graduate Theses, Dissertations, and Problem Reports collection by an authorized administrator of The Research Repository @ WVU.

For more information, please contact researchrepository@mail.wvu.edu. 
From Peasant to Pariah:

Changing English Perceptions of

the Irish from the 1820s Through the 1860s

Traci J. Scully

Dissertation submitted to the

College of Arts and Sciences

At West Virginia University

in partial fulfillment of the requirements

for the degree of

Doctor of Philosophy

in

History

Joseph Hodge, Ph.D., Chair

Katherine Aaslestad, Ph.D.

Kate Staples, Ph.D.

Lisa Weihman, Ph.D.

Sandra den Otter, Ph.D.

Department of History

Morgantown, West Virginia 2011

Keywords: Ireland, Identity, Victorian England, Empire Copyright 2011 Traci J. Scully 


\section{Abstract \\ From Peasant to Pariah: \\ Changing English Perceptions of \\ the Irish from the 1820s Through the 1860s}

\section{Traci J. Scully}

While the historiography of English perceptions of the Irish in the later period of the Victorian era is extensive, there is a dearth of research in tracing the origins of these perceptions. The connection between England and Ireland dates back centuries, and the relationship was neutral at best and extremely violent at worst. Historians such as L. Perry Curtis have analyzed the mass media of these later decades to argue that the English saw their neighbors as subhuman creatures in the racial hierarchy.

However, this image did not emerge from a single event, but rather evolved over the tumultuous earlier decades marked by violence, starvation, disease, and immigration. And it did not evolve without a clear purpose. The Act of Union brought Ireland into the larger political unit of the United Kingdom. In theory, the Irish were now full partners within that kingdom, though in reality their Catholicism became the means to deny them equal status and rights. In the fight for emancipation, many Irish became involved in the Chartist movement. As the movement grew in strength, the press increasingly characterized it as both aggressive and Irish, linking the two in the public perception of this growing threat to society stability.

The Great Famine followed the Chartist workers' revolution, and millions of Irish starved or emigrated between 1845 and 1855. In spite of numerous policies and plans from Parliament, the disaster seemed to have no end or solution. English relief taxes vanished and the Irish poured into industrial centers like Liverpool and Manchester. Ghettos, disease and poverty became synonymous with the Irish people, thus laying the groundwork for the middle class to conveniently strike this biologically poverty-stricken race from their charitable guilt. 


\section{Acknowledgements}

A number of people have proven to be vital throughout this challenging process. From this project’s inception, Dr. Joseph Hodge has shaped my thoughts, my analysis, and my writing to bring this work to its conclusion. Both Dr. Kate Staples and Dr. Lisa Weihman introduced me to avenues of research I had not previously considered. Dr. Katherine Aaslestad honed my understanding of the events in England as they related to the larger context of Europe during the Victorian period. Dr. Sandra den Otter provided valuable insight into the complexities of the period that opened new areas of research. My family’s support has been at the core of this project from its beginning. Without their understanding and patience, this work would have never seen the light of day. Thank you is not enough for Bobbi’s editing, demanding scholarship, stimulating debate, and incredible intellectualism.

Traci J. Scully 


\section{TABLE OF CONTENTS}

Introduction............................................... page 1

Chapter One: Prelude to the Victorian Period..................... page 51

Chapter Two: Chartism...................................... page 86

Chapter Three: The Great Famine............................. page 141

Chapter Four: Immigration................................ page 204

Chapter Five: The Irish Other: A Convenient Truth................ page 256

Conclusion............................................... page 297

Bibliography............................................ page 312 


\section{Introduction}

In the late 1700s, Irish terrorism, known as the 'outrages,' renewed the centuriesold conflict between England and its internal colony. The most significant of these 'outrages' was the United Irishmen Rebellion of 1798 that helped drive the Act of Union through the British Parliament. By the early 1800s, the violent push for independence was coupled with a variety of political angles from Catholic Emancipation to the demand for the repeal of the hated Act of Union. As the nineteenth century progressed, English paternal kindness toward the Irish began to change. The violence of 1848 aimed at landlords, both organized and unorganized, would prove to be a turning point in the attitudes and perceptions of the English toward their neighbors across the sea. The Irish were proving to be a serious threat to the stability of the British Empire and the United Kingdom in particular. Amidst increasing world tensions and economic problems, the inhabitants of this tiny island became the target of English rage. As cracks emerged in the illusion of this unified United Kingdom, the English popular press synthesized the zeitgeist of the era to define a hierarchal social structure. The outcome, whether intended or not, was the creation of an English national identity to remain, perhaps in image only, the dominant force of the imperial age. In order to create the hierarchy, this synthesis necessitated the creation of categories, essentially 'us' and 'them.' While these divisions were not always clear-cut and well-defined, they nonetheless provided a loose framework from which to establish notions of English and non-English. The Irish, as the threat nearest to English shores, became an internal other; the antithesis to that which was English and to that which was civilized and proper. 


\section{The questions central to the argument}

Even before the extensive colonial expansion of the late nineteenth century, racial theory in Britain began to crystallize in response to contact with the country's closest colony, that of Ireland. The prevailing mentality in the early decades of the 1800s, coming from the philosophies of the Enlightenment, stressed the common humanity of all peoples and races. Even though many European societies accepted the commonplace hierarchal distinction between savage, barbarian, and civilized cultures, the English middle and upper classes had enormous confidence that under justly administered British rule, all peoples, through education and religious influences, would be assimilated into superior Protestant British ways. Articles appeared regularly to discuss the importance of education in raising the morality and living standards of both the poor in England and the colonial natives across the globe. ${ }^{1}$ By mid-century however, that perspective shifted to a more biologically driven hierarchy that attributed poverty and ignorance to genetics, thus precluding any improvement in the condition of the lower races. The Anglo-Saxon and the Celt, in relation to Ireland, were racially different, thus making one racially inferior. Scientists such as Robert Knox and later works from Francis Galton and others solidified this racial theory as scientific fact.

Ireland, as England's oldest and most consistently problematic colonial holding, figured prominently in this shift in attitudes before it was applied to the far-flung regions of the empire. Sources from the early decades of the 1800s indicate a paternal mentality toward the Irish population. During the famine, liberal ideals seemed to prevail for a

\footnotetext{
${ }^{1}$ For example see: “Account of the Discovery and Education of the Savage of Aveyron,” Universal Magazine, April, 1802; “On the Education of the Poor,” Universal Magazine, September, 1807, “THE FUND OF MERCY; Or, An Institution for the Prevention of Prostitutes appearing in the Streets, and for the Relief and Employment of Destitute and Forlorn Females,” Methodist Magazine, April 1813.
} 
time, but by the late 1840s, the tone begins to shift to a harsher perspective. What forces, both within England itself and externally, influenced this shift? How influential were the socio-political movements, such as Chartism, in the pre-famine years? What role did the Irish themselves play in the development of the English mentality, particularly as immigration into England increased dramatically in the post-famine years? What was the dissenting perspective and how influential was that voice to the tax-paying middle class? In the wake of the liberal failure during the Irish famine, how influential was the increasing violence perpetrated by Irish radicals? Most important, how did the English benefit from this new biological understanding of poverty? Answers to these critical questions will help determine not only the nature of English attitudes toward the Irish, but also help to analyze the distinct shift in those attitudes from the mid-century onward.

\section{Arguments and Conceptual Framework}

This dissertation is a study of the evolution in English perceptions of Irish identity during the Victorian period. Events in England and Ireland from the 1820s until 1870 transformed the already complex relationship between the two nations, and contributed to a distinctly negative image of the Irish that evolved in the second half of the century. There were three critical events that shaped English perceptions: Irish involvement in the Chartist movement, the Great Irish Famine, and the waves of immigration into England in the late 1840s and 1850s. Chartism and immigration both predated the famine, but the tone set by the radical movement, combined with the increasing numbers of Irish on English shores in the wake of the famine, helped to harden English attitudes. These events, as interpreted through the popular media, helped to crystallize a more hostile, although not entirely uniform, viewpoint toward the Irish population. This viewpoint was 
then reinforced and solidified by the emergence of scientific racism in the later decades of the century. Throughout the 1850s, the government and the English middle class used this biological discourse to disengage the Irish from the growing social welfare system in order to maintain their own financial status and ease the tax burdens of charity.

These perceptions evolved during a dynamic and problematic period of immigration. During the mid-1800s, the Great Famine struck Ireland, leaving over a million dead across the island. As conditions deteriorated in Ireland, the people began looking elsewhere for their survival. While Canada, the United States and Australia became popular destinations, the shores of England were close at hand, and hence became the most popular point of entry. These new immigrants quickly migrated to the urban centers, most notably the Manchester/ Liverpool area and London. They settled into what became known as 'Irish Towns;' neighborhoods with heavy concentrations of other Irish immigrant families. Residential segregation became the norm as the immigrant numbers continued to rise.

Irish migration into England had, in reality, begun years earlier, but the devastation of the famine years heightened the exodus. Historian Arthur Redford argues that the "flood of Irish pauperism which swept over England during the great potato famine no longer appears as an isolated disaster" but instead needs to be seen in its true character as the "culminating wave of a rising tide of Irish immigration which had been steadily creeping further over England for many years previously."2 It was this persistent exodus, according to Redford, that was by far the most significant feature of Irish migration during the nineteenth century. More recent works from historians such as

\footnotetext{
${ }^{2}$ Arthur Redford, Labour Migration in England, 1800-1850 (England: Manchester University Press, 1976), 131.
} 
Kevin Kenny support this argument. The years of starvation and mismanagement of local affairs had taken its toll on Ireland, and many of those who left found their way to English shores. Immigration records for this period are complex, as there was no official census before 1821 and place of birth was not recorded until 1841. Nor was there a national system of vital registration before 1864, with the exception of Protestant marriages whose registration began in 1844. Many historians have examined parish records in order to analyze population data for England throughout the 1800s. According to population surveys conducted in 1841, the total number of Irish immigrants in England was recorded at 289,404 . The census takers of 1841 estimated that about five percent of the Irish population was living in counties in which they were not born, and many of those had travelled to the industrial cities of England. ${ }^{3}$ The year 1851 is considered the watershed year for Irish immigration, with a staggering one-quarter of a million people leaving Ireland in a single year. ${ }^{4}$ That year the Irish-born represented 2.9 percent of the total population of England. The figures for the urban centers were far greater. In London, the Irish were 17.6 percent of the total population of the city. Liverpool recorded 11.9 percent of the population as Irish and Manchester was 8.3 percent Irish. ${ }^{5}$ By 1861 , the immigrants had increased to 806,000 ${ }^{6}$ R.E. Kennedy estimates that from 1845 to 1870, over three million Irish left the country for various ports and from 1871 to 1891 , another 1.1 million emigrated. The Irish, he stresses, are still the largest immigrant group

\footnotetext{
${ }^{3}$ L. Kennedy and L.A. Clarkson, "Irish Population History, 1700-1921," in An Historical Geography of Ireland, eds. B.J. Graham and L.J. Proudfoot (London: Academic Press, 1993), 177.

${ }^{4}$ Ibid, 175.

${ }^{5}$ Roger Swift, "Heroes or Villains? The Irish, Crime, and Disorder in Victorian England,” Albion: A Quarterly Journal Concerned with British Studies, Vol. 29 No. 3 (Autumn, 1997): 400; B. Collins, "The Irish in Britain 1780-1921,” in An Historical Geography of Ireland, ed. B.J. Graham and L.J. Proudfoot, (London: Academic Press, 1993), 342.

${ }^{6}$ M.A.G. Ó Tuathaigh, "The Irish in Nineteenth-Century Britain: Problems of Integration,” Transactions of the Royal Historical Society, $5^{\text {th }}$ Series 31 (1981): 153.
} 
into Britain since records began in $1841 .{ }^{7}$ Economist F.W. Farrar reported that the number of Catholic chapels increased by 231 from 1841-1850, another, less obvious indication of the growing presence of the Irish in England. ${ }^{8}$

\section{Defining Nation as a Basis for Identity}

In order to analyze the development of the perceptions of the Irish in England, the earliest origins of the cultural differences between these two groups must be examined. Historians have long had difficulty placing Ireland within the larger Empire, particularly when compared to India and Africa. The earliest invasions of Ireland occurred long before a distinct concept of nation or national identity had developed. Yet the chronicles from various regions across Ireland make definitive references to outsiders that were from foreign shores and not simply members of distant clans or septs. Contact between the two nations continued and escalated into violent conflict while at the same time, each nation was slowly developing a concrete concept of national identity. The central question concerning Ireland rests therefore upon its colonial status. Was it a colonial holding in the same way India or Africa was? If not, then precisely what was Ireland to not only England, but the greater Empire? What common characteristics does Ireland share with both India and Africa in terms of colonial patterns in order to define it as a colony? This works positions Ireland as a colony until the Act of Union officially changed its legal status. Although the nation held differing titles over the centuries, such as a Lordship, and was thus governed by differing rules and regulations, the consistent

\footnotetext{
${ }^{7}$ R.E. Kennedy, The Irish Emigration, Marriage and Fertility, (London: University of California Press, 1973), 27.

${ }^{8}$ F.W. Farrar, “The Asserted Growth of Roman Catholicism in England," 58 Fortnightly Review (October, 1895): 557.
} 
pattern of invasion and forced assimilation mirrors the colonial policy, to a greater or lesser degree, across the whole of the British Empire.

These colonial patterns between England and Ireland are among the oldest in the British Empire. Contact between the English and the Irish began in the 1100s with the Norman Invasion. But was there enough of a sense of nation to create a clear clash of cultures between English and Irish in this period? In order for a national identity to form, two factors must exist. First, there must a defined sense of nation. Second, there must be a defined sense of other nations beyond borders. If these two factors existed as early as the 1100s, then the Norman Invasion serves as the true origin of the cultural clashes that reached their height in the late 1800s and early 1900s. The animosity that developed during the Victorian Period did not arise only from socio-political events during that era, but had it roots in the shared history of the two nations. It is critical to understand this shared history and the cultural clashes that emerged from that history as it creates a multifaceted picture of the events of the 1800s. Chartism, the Great Famine and the subsequent immigration problems were not entirely new as Irish problems of some sort punctuate English history.

The term natiove in medieval Ireland was used in the older sense of familia or gens; in fact, chroniclers used the term natio in thirteenth century Ireland more often to describe the great families of Anglo-Normans such as the Earls of Louth and Kildare. ${ }^{9}$ Even at the end of the fourteenth century the term natio was used to describe particular political factions in Ireland, such as the Anglo-Norman factions termed "diverse nations

\footnotetext{
${ }^{9}$ James Lydon, “The Middle Nation,” in Concepts of National Identity in the Middle Ages, eds. Simon Forde, Lesley Johnson, and Alan Murray (Leeds: Leeds Texts and Monographs, 1995), 3.
} 
Anglice” who revolted in Munster in the middle of the fourteenth century. ${ }^{10}$ Later in the century other rebellious Anglo-Norman lords were also termed nationes. These terms, according to historians, were not applied to a distinct Irish people as the modern usage now conveys and thus did not clearly identify a unique Irish nation in contrast to a unique English nation.

To confuse matters more, though, the term natio was also used to describe wider ethnic groups with shared identities. This use of natio is remarkably similar to the modern usage of the term 'nation.' In one example, the term natio is juxtaposed with the term gentes; the meaning of the term gentes Hibernie nationis, according to historians, reflects a mental distinction between a family and a wider social grouping. In this case, that wider social grouping is Hibernie nationis. ${ }^{11}$ The term was also used in an attempt to unite the lands of Ireland and Scotland in the fourteenth century, thus muddying any attempt to narrow its definition to the modern interpretation. According to King Robert I of Scotland, the natio of Ireland and Scotland, which shared a broad common language and similar customs, should be given its liberty from England. From this perceptive, natio could be defined simply as “common language and custom” in this period. ${ }^{12}$

Beginning in the ninth century, the terms gaill and gall appeared in Irish annals and were used to describe "native" and "foreigner" respectively. The terms, first used to distinguish native Irish from Scandinavian invaders, reflected distinct geographic and ethnic identities. The terms gaill and gall were used again throughout the Middle Ages to describe natives and foreigners as well. When the Anglo-Normans arrived in Ireland in

\footnotetext{
${ }^{10}$ Ibid, 3.

11 J.A. Watt, "Negotiations between Edward II and John XXII Concerning Ireland,” Irish Historical Studies, No. 37, X (March 1956): 16.

12 Ibid, 17.
} 
the late twelfth century, they were called gall since they were in fact foreigners. ${ }^{13}$ In the Irish annals, the terms saxoin and sagsan were used to describe foreigners from England in particular. In the fourteenth century Irish edition of Expugnatio Hibernica, the translation of Gerald of Wales appeared as if he was making a distinction between the foreigners who lived in Ireland and those who came from England, but the distinction is not consistent. ${ }^{14}$ The distinction is more clear throughout the fourteenth century, when the in habitants of Ireland with Anglo-Norman origins labeled themselves mediae nacionis, or "middle nation,” in recognition perhaps of their awkward status. In the fifteenth century they were often referred to as Irish by those living in England, yet to the native Irish they were still considered gall. ${ }^{15}$ While these early sources do not reflect the concept of a modern nation, they nonetheless indicate that the English and the Irish saw themselves as culturally distinct. These distinctions, therefore, laid the groundwork for what would later become the cultural and biological hierarchies of the Victorian Era.

\section{Ethnic Identification as a Unifying Force}

In spite of this imprecise vocabulary, the primary sources from medieval Ireland suggest that the people of this period, in both Ireland and England, saw clear differences between themselves in terms of ethnicity, culture, and language, but those differences led to ambiguity more than clarity in definition. In spite of increasing scholarly attention to this issue, the concrete meaning of ethnicity and nationality in this period has remained elusive from both a lack of sources and a dramatically shifting political landscape. This confusion has inspired a plethora of definitions for each term and a host of theories

\footnotetext{
${ }^{13}$ The Ulster Annals, 1170.3: 163.

${ }^{14}$ Whitley Stokes, “The Irish Abridgement of the Expugnatio Hibernica,” English Historical Review XX (1905): 77-115.

${ }^{15}$ E. Curtis and R.B. McDowell, Irish Historical Documents (London: Methuen, 1943), 38.
} 
regarding their interrelationship. The best definition of ethnicity arising from the literature stresses it as the construction of cultural differences through social interaction. It is a portion of a social relationship between agents who consider themselves to be culturally distinct from members of other groups with whom they have regular communications, and it is often characterized by metaphoric or fictive kinship. ${ }^{16}$ Cultural differences inform ethnicity, but they are not the equivalent to it. Ethnicity is instead the communication of cultural differences through social interaction.

Using this broad definition, Anglo-Irish relationships can thus be analyzed within the framework of culture clashes from its earliest period onward. W.R. Jones argues that the negative image of the Irish arose as a consequence of the encounter between AngloNorman and Angevin England ('richer, more highly centralized, feudal and manorial') and Celtic societies ('tribal, mobile, disaggregative'). The outcome of these encounters was English hostility and contempt toward Celtic societies. They were seen as inferior, barbarous, and primitive. The portrayal of Celtic society as savage, with attendant poverty, indolence, and brutality became entrenched in English imagery from medieval times, and provided a moral justification for continued English efforts to dominate or destroy the Celts. Jones sees this as illustration of a continuing theme in world history the competition of rival cultures, dramatized by the stronger and better organized one dominating over the lesser. There is a constant pattern whereby ‘civilization' collides with 'barbarism.' 17

\footnotetext{
${ }^{16}$ Thomas Hylland Erikson, Ethnicity and Nationalism: Anthropological Perspectives (London: Pluto Press, 1993), 10, 37, 41.

${ }^{17}$ W. R. Jones, "England Against the Celtic Fringe: a study in cultural stereotypes," Journal of World History, 13 (1971): 155-171.
} 
Harold Mytum, in his work The Origins of Early Christian Ireland, examines the development of Irish ethnicity through this system of communication and culture clash as well. Mytum contrasts Ireland during the Iron Age period with the Ireland that developed after the domination of Christianity, essentially from the fifth century to the initial Viking raids and settlements. Unlike many scholars, his premise does not rest solely on the role of Christianity in shaping early Irish ethnicity. He argues instead, that while the mass conversions were quite significant, they were not the sole influencing element across Ireland. During this time period, Ireland had settlements in Britain, and it was the transmission of ideas through social interaction and the ties of social kinship that shaped the Irish just as much as the early Catholic Church.

Using extensive archaeological resources, Mytum outlines a complex web of subsystems throughout Irish society, including a belief system, a social system, a subsistence economy, technology and craft activity, and long-distance trade and exchange. These systems, he argues, were influenced by both the Church and contact with England. Ireland in the Iron Age was strictly controlled by the clan and a network of kinship, but this slowly shifted to a greater emphasis on the individual as new systems replaced the older clan order. The Church, with its stress on personal salvation, increased the spiritual identity of the individual. Trade with Anglo-Saxon England, and the subsequent wealth from that trade, increased the material identity of the individual. This rise of the individual was, according to Mytum, the pre-eminent cause of social change and the evolution of Irish identity during this period. ${ }^{18}$

During this same time period, the Anglo-Saxons were undergoing a similar process of identity formation. This group would later play a considerable role in the

\footnotetext{
${ }^{18}$ Harold Mytum, The Origins of Early Christian Ireland (London: Routledge, 1991), 48.
} 
formation of the Irish identity, so it is important to review the scholarship on their early development in order to understand their later influence on Ireland. Anglo-Saxonism and the Construction of Social Identity, edited by Allen Frantzen and John Niles, is a significant contribution in the field of scholarship on Anglo-Saxon ethnicity. This collection of essays is divided into two sections, the early Anglo-Saxons and the later Anglo-Saxons. The essays on the early period are most important to the consideration of medieval identity. Mary P. Richards and Janet Thormann explore the construction of the concept of Anglo-Saxonism by the Anglo-Saxons themselves. Allen Frantzen and Suzanne Hagedorn examine sources that offer an outside perspective of the Anglo-Saxon. In his introduction, Frantzen defines Anglo-Saxonism as "the process through which a self-conscious national and racial identity first came into being among the early peoples of the region.” ${ }^{19}$ Frantzen posits that language, common descent, and inherited characteristics were fundamental elements of Anglo-Saxonism, and he analyzes these facets within a microcosm of history. Frantzen believes that Gregory the Great's encounter with Anglian slave boys in a Roman marketplace, described by both Bede and Reformation historian John Bale, highlights cultural elements that illustrate the developing identity of the Anglo-Saxons of England. Richards explores this process of identity development within the laws of Old England. She argues that the old laws captured the essence of social norms and cultural changes over time to reflect a unique Anglo-Saxon identity, influenced by both Christianity and the emerging English language. Thormann analyses the Anglo-Saxon chronicle poems, and she argues that this

\footnotetext{
${ }^{19}$ Allen Frantzen, Anglo-Saxonism and the Construction of Social Identity, eds. Allen Frantzen and John Niles (Florida: University Press of Florida, 1997), 1.
} 
body of poetry, as well as a growing unification of language, helped to define a sense of community with a unique identity.

In his essay, John Niles ties the varying themes presented together through his theory of culture as appropriation. He distinguishes appropriation from the related terms "acculturation" and "assimilation” by arguing that neither the concept of assimilation nor that of acculturation "foregrounds human agency.”20 Appropriation implies “a consciousness of actions to be taken after consideration of self-interest.” Culture is then simply a collection of appropriations by individuals or groups, informed by and expressive of certain specific ideologies. ${ }^{21}$ This theory of appropriation and the corresponding definition of culture can then be used to "make good sense of the phenomenon of Anglo-Saxonism,” that developed throughout England during the $1800 .^{22}$ Niles argues that the Victorian English, through the media, developed a sense of themselves as Anglo-Saxons based on selected characteristics appropriated from history. The media selected those elements that fit a specific image of the Anglo-Saxon in relation to modern, imperial England and created an identity based on those elements, both real and imagined.

Like the Anglo-Saxons, the Normans would also later prove vital in the development of the Irish identity. Nick Webber explores this group’s unique cultural identity in his work, The Evolution of Norman Identity, 911-1154. Webber's contribution is unique in his use of sociological theories, in addition to historical research, to examine the development of Norman identity in the medieval period. ${ }^{23} \mathrm{He}$ also clearly delineates

\footnotetext{
${ }^{20}$ John Niles, “Appropriations: A Concept of Culture,” Anglo-Saxonism, 205.

${ }^{21}$ Ibid, 205-206.

${ }^{22}$ Ibid, 220.

${ }^{23}$ Nick Webber, The Evolution of Norman Identity, 911-1154, (London: Boydell Press, 2005).
} 
between the internal perspective of Norman group identity and the external perspective of that same identity, allowing for illuminating comparisons between self-perception and the view from other cultures. His thesis is straightforward in that he, like Nicholas Canny, argues for a rather unified Norman identity by the 1100s, but his use of a theoretical framework gives new insight into the sources and the evolution of that identity. Webber divides his work into three segments: in Normandy up to 1066; in the Mediterranean up to 1154; and in the Anglo-Norman realm between 1066 and 1154 with the accession of Henry II. In each region, he examines a variety of sources, both internal and external. He uses the sources to analyze how each 'side' constructed an identity of the 'other,' and how this construction influenced the development of the Norman identity within each region. Individual chroniclers, for example, illustrate how regional attitudes evolved over time as Norman contact with local cultures changed, particularly in the south of Europe, and then how those attitudes later evolved into distinct identities, both Norman and the other.

Certain themes emerge from the sources that Webber defines as important to the formation of the Norman identity. According to the early sources, the dominant characteristics that remained throughout the centuries and throughout the three major regions were the Norman military prowess and Norman piety. Webber argues that these traits alone were not the only factors in their successful expansion. Norman strength, according to Webber, also rested in their ability to assimilate other cultures, creating a diverse yet cohesive culture. This assimilation played a significant role in the changing political structure of Northern Europe. Webber argues that as ethnicity gave way to 
nationalism by the 1100 s, leaders began to rule over lands, rather than over collections of peoples.

New interpretations of identity, on a government level, were then needed to absorb diverse social and ethnic groups into a 'nation,' rather than a kinship-based tribe. Using sociological theory, Webber argues that the Norman kings created this cohesive identity by stressing common traits, such as military prowess and piety, as well as establishing a distinct other in outside cultures. As the other became more clearly defined, a unique Norman culture emerged to unite what was previously a rather diverse, culturally mixed group of people throughout the Norman kingdoms.

Webber's work is critical to the study of the development of identity throughout the Middle Ages as he lays the foundation for an identity that will eventually become the English view of themselves within the Empire. By using sociological theory, he creates a framework from which to analyze the actions of the Norman leaders, and the subsequent impact these actions had on the peoples within the Norman kingdoms. He also creates a framework from which to analyze the perspectives of Norman writers, and those reflecting upon the Normans within their culture. Webber acknowledges that these frameworks are modern constructions and focus primarily on present-day conditions, but he stresses their importance in understanding the eleventh and twelfth centuries as well. These theories, Webber posits, allow scholars to examine the past from new perspectives, thus gaining insight into the sources even though the original authors were not necessarily thinking in those terms.

Unlike Mytum's work, Anglo-Saxonism and the Construction of Social Identity and The Evolution of Norman Identity, 911-1154 both link the concept of ethnicity to the 
newly emerging medieval concept of nationality. This link is problematic, however, as nationality is often viewed beyond the scope of just social interactions. Nationality, Benedict Anderson argues, is an ideological construction emphasizing an organized selfconsciousness within a territorially defined population. It is an imagined political community, unified not through social interaction but creative propaganda centered around common themes. ${ }^{24}$ According to Geoff Ely and Ronald Grigor Suny, nationality is a "complex, uneven, and unpredictable process, forged from an interaction of cultural coalescence and specific political intervention which cannot be reduced to static criteria of language, territory, ethnicity or culture.”25 Scholars have utilized definitions of this sort to examine how nations were invented or forged through symbols, images and other forms of ideological work. To paraphrase Eric Hobsbawn, nations do not create states or nationalism, it is the state and nationalism that merges to create the nation. ${ }^{26}$

James Muldoon explores this hybrid of cultures within a territory, the imagined political community, in his work Identity on the Medieval Irish Frontier: Degenerate Englishmen, Wild Irishmen, Middle Nation. While Mytum discusses the British influence coming from outside of Ireland, Frantzen's collection focuses on the Anglo-Saxon, and Webber centers on the Normans, Muldoon's work blends these cultures within the boundaries of Ireland itself. Muldoon posits a frontier theory, in the Frederick Jackson Turner tradition, for Ireland. The Anglo-Saxons and the Vikings, as both cultures settled in Ireland, blended with the local populace, thus creating a new identity for the people on

\footnotetext{
${ }^{24}$ Benedict Anderson, Imagined Communities (New York: Verso Books, 2006), 7.

${ }^{25}$ Geoff Ely and Ronald Grigor Suny, "Introduction: From the Moment of Social History to the Work of Cultural Representation,” in Becoming National: A Reader, ed. Geoff Eley and Ronald Grigor Suny (Oxford: Oxford University Press, 1996), 8.

${ }^{26}$ Eric J. Hobsbawn, Nations and Nationalism Since 1780 (New York: Canto, 1990), 10.
} 
the new frontiers. This frontier identity then became the basis for later frontier mentalities, such as the American colonial experience. ${ }^{27}$

Muldoon bases his thesis on Aristotle's theory of humanity, and the human ability to evolve from barbarism to civilization. Aristotle argued that all humans moved from nomadry and pastoralism to permanent settlements, agriculture to urban life. For Northern Europe, the process of expanding civilization into other regions began in Ireland with the Vikings and the Anglo-Saxons. Ireland was at the time, a "middle nation,” civilized through Christianity, but still pastoral with the old tribal systems clearly in place. ${ }^{28}$ Muldoon argues that the Vikings brought the concept of the urban center to Ireland with the development of trading outposts. The Anglo-Saxons brought “mainstream European society” and the early conceptions of the "mainstream Latin Church" to the island. ${ }^{29}$ These two distinct cultural elements, plus the native Irish, blended on the wild frontier of Ireland through Ely and Suny’s “complex, uneven, and unpredictable process," to create a more ethnically diverse identity beyond the "static criteria of language, territory, ethnicity or culture.”30 As this research indicates, there was a distinct sense of difference between the Irish and the English long before the Victorian period. Although medieval England and Ireland were far from the concept of a modern nation, each population had a cultural framework in which they defined their own unique status. This unique status was then contrasted with outsiders to separate native from foreigner. These distinctions only intensified over the centuries as Europe developed a more concrete understanding of nation throughout the 1700s and 1800s. By the Victorian

\footnotetext{
${ }^{27}$ James Muldoon, Identity on the Medieval Irish Frontier: Degenerate Englishmen, Wild Irishmen, Middle Nation (Florida: University of Florida Press, 2003).

${ }^{28}$ Ibid, 115.

${ }^{29}$ Ibid., 66-69.

${ }^{30}$ Geoff Ely and Ronald Grigor Suny, Becoming National: A Reader, 8.
} 
Era, these differences were subjected to the pseudo-sciences of the period, thus creating a rational, scientific basis for centuries of culture clashes.

\section{Secondary source analysis of English Identity}

As Irish immigration increased within England, very real social and political issues emerged for the people of Britain, thus fuelling tension between the native population and the new immigrants. There were very real conflicts developing in the social and political fabric of England, from disease and poverty to the continued threat of violence through Fenianism. The English reaction to these problems was framed within the scientific racism and class hierarchies of the era, and thus the Irish became the other among the English. Michael Hetcher, in his work Internal Colonialism: The Celtic Fringe in British National Development, 1536-1966, defines Ireland as an internal colony within the larger political structure of the United Kingdom. The Irish people, he argues could never blend into a larger British identity because of the economic gulf dividing the two nations. Distinctly Marxist, Hetcher believes that as England sapped the resources of its neighbor, an inequality of labor and wealth emerged. It was this system of exploitation that laid the foundation for the creation of a dominant and superior English imperial identity in contrast to the weaker Celtic subaltern.

Linda Colley has argued that internally, British identity was forged in response to a series of wars with France during the eighteenth and early nineteenth centuries. Britain was confronted by a hostile other, Celtic, Catholic France, which encouraged the people of the United Kingdom to see themselves as a single nation. Britain set itself in opposition to French Catholicism and absolutism, thus establishing an identity firmly cemented in popular Protestantism, constitutional monarchism, commercial trading, and a 
Parliamentary government. ${ }^{31}$ She, however, struggles with Ireland because while it was one portion of the United Kingdom, the Irish were a distinct cultural group that did not assimilate into the 'British' framework. In defining 'Britishness,' Colley does not include the Irish as a tool in shaping this definition. She argues Catholic France helped the English carve out their national identity, yet Catholic Ireland did not? As the internal other, the Irish should have had an even greater impact on the formation of English identity. Colley chooses instead to place them along with the Scots, the Welsh, and other groups absorbed into the United Kingdom, but excludes them from her analysis because they were different. She does not address how they can be similar yet different and how that contradiction helped to shape English identity.

While works such as Hetcher's and Colley’s provide valuable structures from which to examine English and Irish identity, they are limited in their scope. As the review of the literature on the medieval period suggests, the nature of nationality is transitory, and shifts in response to changing social, political, and intellectual movements. ${ }^{32}$ According to J. Penrose's theories on the development of nations, these socio-political units are not immutable givens, but are instead the product of human thought and action. The forging of a nation is a flexible, dynamic process, and should not be thought of as a single event, but an on-going process. ${ }^{33}$ Inherently open to debate, national identity is constantly redefined as circumstances change. In response to such changes, such as Chartism, the Great Famine, immigration and the impacts on English society, the myths,

\footnotetext{
${ }^{31}$ Linda Colley, Britons: Forging the Nation, 1707-1837 (New Haven: Yale University Press, 1992), 101145.

${ }^{32}$ Eric Hobsbawn, Nations and Nationalism Since 1780: Programme, Myth and Reality (Cambridge: Cambridge University Press, 1992), 11.

${ }^{33}$ J. Penrose, "Reification in the Name of Change: the Impact of Nationalism on Social Construction of Nation, People and Place in Scotland and the United Kingdom," in Constructions of Race, Place and Nation. eds. P. Jackson and J. Penrose (London: UCL Press, 1993), 28.
} 
symbols, and rhetoric of national belonging were alternately appropriated and reexamined. National identity must, therefore, be studied in response to particular historical moments and changing historical circumstances.

This is particularly relevant when examining Irish identity within the larger colonial context of the British Empire. Ireland proved quite problematic to Colley's thesis of a distinctly Protestant British identity forged in opposition to French Catholicism. Catholic, rebellious and seemingly irreconcilable, Ireland falls beyond the scope of Colley’s study. Ireland was a perennial problem for the British as well, viewed as a colony rather than an integral part of the nation. Once the Act of Union passed, however, Ireland was technically absorbed into Great Britain, thus changing its status once again. The contentious Irish history of rebellion, therefore, was not quelled with the Act of Union in 1800 as many had hoped. Separatist revolts continued well into the 1900s that successfully divided part of Ireland from its place within the United Kingdom.

The current trends in historical analysis reflect Penrose's theory of a dynamic and shifting concept of national identity. The 1800s were a dynamic, if misguided, intellectual period filled with a number of tumultuous events. Scientific and social theories emerged outside of the economic realm, to influence the development of England's national identity, and more importantly, England's perceptions of its colonial holdings, including Ireland. Chartism, the famine, and the extensive immigration into England were concrete socio-political factors upon which those racial theories were built. Historians no longer view the metropole and the periphery in such binary terms such as L.P. Curtis argued in his 1968 work, Anglo-Saxons and Celts: A Study of Anti-Irish Prejudice in Victorian England. They instead embrace a more nuanced relationship 
between the two nations while still acknowledging the prejudice and conflict of the period. ${ }^{34}$ The Empire is now seen as a dynamic interplay between colonized and colonizer, thus creating a multifaceted concept of identity on both sides of the imperial fence.

This new reflection on empire evolved in response to the traditional view of the British Empire in which all power and control emanated from England without any credence given to the colonial subjects as a force of change or power. This new, more nuanced examination places Ireland squarely within the United Kingdom and just as importantly, as a part of the larger Empire. In 1988, Boyd Hilton wrote The Age Of Atonement: The Influence of Evangelicalism on Social and Economic Thought, 17951865. ${ }^{35}$ While Boyd's work is not the first in this new perspective on Empire, his work is a challenging and controversial look at the role of religious thought in the development of policy. He argues that the laissez-faire economic policies supported by large numbers of English economists were countered by more religiously conservative economic theorists, such as those of the Presbyterian faith. These more conservative religious thinkers saw poverty and the business cycle as a reflection on divine punishment and redemption from original sin. They looked to Malthus for support in transferring moral standards onto economic policy. Malthus believed it was the breakdown of sexual restraint that was causing the serious overpopulation problem, and thus increasing the strain on economic structures. If, according to the religious economists, the economy was driven by God and not the government, social and economic order would be maintained. While Ireland is not

\footnotetext{
${ }^{34}$ L. P. Curtis, Anglo-Saxons and Celts: A Study of Anti-Irish Prejudice in Victorian England, (Connecticut: University of Bridgeport, 1968).

${ }^{35}$ Boyd Hilton, The Age Of Atonement: The Influence of Evangelicalism on Social and Economic Thought, 1795-1865 (New York: Claredon Press, 1988).
} 
central to his thesis, Hilton nonetheless stresses that the Peel government was largely responsible for the support and the success of these economic theories. This being the case, it was the Peel government that set the stage for England's policies toward Ireland during the critical famine years. If policy was indeed driven by God's divine plan, how then was the staunch Catholicism of Ireland factored into a Protestant evangelical economic policy? Hilton’s unconventional analysis does not directly answer these questions, but he offers a far different interpretation of economic policy that places Ireland and other non-Protestant nations in a very unique and problematic role within the Empire.

In 2006, Hilton published A Mad, Bad and Dangerous People? England, 17831846. ${ }^{36}$ Building on his 1988 analysis of religious economics, Hilton argues that the first half of the 1800 s was a reactionary period against the encroaching changes to society, including the growing empire. He posits that amidst the revolutionary flames fanning across Europe, Parliament, under Peel’s guidance, adopted a “moral rehabilitation of the state” mentality. ${ }^{37}$ The policies, politics and intellectual strategies of the government were designed to repress, divert, and sway the restless masses into submission. Like his earlier work on religious economic theory, Hilton only marginally addresses Ireland, but his arguments apply broadly across the colonial holdings of the Empire. He argues that Peel, influenced by evangelical economics, sought the "politicization of society as a whole” and, he posits, a political economy became popular because governments “adopted economic policies and not the other way round.”38 This moral guidance became the ideological and practical basis for economic decisions across the empire. With this in

\footnotetext{
${ }^{36}$ Boyd Hilton, A Mad, Bad and Dangerous People? England, 1783-1846 (Oxford: Claredon Press, 2006).

${ }^{37}$ Ibid, 319.

${ }^{38}$ Ibid, 31, 275.
} 
mind, Hilton's analysis in both works frame the English approach to Ireland quite differently from the radical, anti-British sentiment often tossed accusingly at the Peel government. Parliament's early response to the famine was, based on Hilton's arguments, not radical, insensitive or unmotivated to help. Ireland's crisis was instead framed by the religious outlook of the time and not by extraordinary anti-Irish prejudice.

As its first colony, historians now recognize that Ireland played a significant role in the development of the British Empire, but as Kevin Kenny argues in his 2004 work, Ireland and the British Empire, the nature of the relationship between Ireland and England has never been clear-cut. Irish society was deeply divided along highly politicized religious lines, and this division, Kenny stresses, serves to politicize Irish history for political purposes. The Great Famine, for example, raises questions about British intervention in Ireland or the lack thereof, and provides ample fuel for nationalist writers to demonize the English. Kenny also points out that it is difficult to situate Ireland within the United Kingdom, as it has been described as both a colony and a kingdom at different periods while at the same time also being, in theory, an equal partner with England in the wake of the Act of Union. Therefore, Kenny posits, Ireland becomes a difficult point of contention within discussions of imperialism. Kenny raises critical questions surrounding Ireland's participation in the greater goals of imperial England. While acknowledging its colonial status as Hetcher does, Kenny argues there was a willingness on the part of the Irish to become actively involved in the Empire. He analyzes the Irish contribution to the power and growth of the Empire and the extent of that contribution, such as the Irish regiments in India. ${ }^{39}$ He concludes that although there were obviously significant problems between the two nations, Ireland was not a "victim

\footnotetext{
${ }^{39}$ Kevin Kenny, Ireland and the British Empire (England: Oxford University Press, 2004), 129.
} 
of a consistent crude” imperialism. ${ }^{40}$ Like the English, some Irish benefited from their role in the British Empire and the country was no less involved in the imperial process as any other portion of the United Kingdom. This position stands in stark contrast to the highly politicized literature of earlier Irish historians who have placed Ireland squarely on the losing, or 'victim' side of the imperial process.

These major works represent only a fraction of the new imperial history of the last several decades in relation to Ireland. Articles featuring more specific analysis also serve to highlight this complex picture of Anglo-Irish relations in Victorian England. Using immigration from Ireland into the United States as his framework, Kevin Kenny argues that the exodus must be examined in more detail than has often been considered. In his 2003 article titled “Diaspora and Comparison: The Global Irish as a Case Study,” he points out that statistically, the peoples from the various regions of Ireland migrated differently. These regional differences contributed to differing economic impacts on the areas of settlement and differing roles for the Irish settling in those regions. ${ }^{41}$ In contrast to L.P. Curtis’ analysis of the Victorian press as a tool against the Irish, Sarah Jane Edge argues that Irish nationalists actually used this medium of expression to their advantage. In her 2004 article titled "Photographic History and the Visual Appearance of an Irish Nationalist Discourse 1840-1870," she analyzes the increasing popularity of the latest technology of the day — the photograph. She argues that these recorded images were so novel that they captured the public’s imagination immediately. Irish nationalists used this fascination to further their cause through the use of portrait photography. She cites Daniel O’Connell as the first of many Irish leaders to be photographed and publicized as

\footnotetext{
${ }^{40}$ Ibid, 135.

${ }^{41}$ Kevin Kenny, “Diaspora and Comparison: The Global Irish as a Case Study,” The Journal of American History, Vol. 90, No. 1 (June, 2003): 135.
} 
champions of the Irish cause. Drawn to the unique images, the propaganda messages could be embedded in the new marvels of the modern world. ${ }^{42}$ Amy Martin, in her article "Blood Transfusions: Constructions of Irish Racial Difference, the English Working Class, and Revolutionary Possibility in the Work of Carlyle and Engels,” repositions these two seminal authors and their opinions on labor unrest and class into the larger framework of empire. She argues that for Carlyle, the national crisis facing Britain was a crisis of Britain's relation to Ireland. ${ }^{43}$ According to Martin, Carlyle's influential formulation of the "condition of England question” demonstrates how early Victorian constructions of the British working-class were formed in relation to Irish racial stereotypes. This ethnic tension, she posits, led to conservative panic concerning the possibility of a workers' revolution. It then became inseparable from the rising anxiety about the integrity of Englishness and Britishness as the first large-scale immigration of colonial subjects began in the wake of the famine. Martin argues that the crisis Carlyle identified in his "apocalyptic assertion of national disintegration" was as much a crisis of colonialism, immigration, and national identity as it was class conflict. Six years after Carlyle, Engels published his influential work. The discourse on the Irish is quite similar to Carlyle, particularly on the critical role of Irish immigration and the increasing discontent among British workers. Both authors, she points out, believed the origins of England's economic, cultural, and racial degeneration sparked a new class consciousness and had, therefore, fuelled working class radical politics. Both authors also attributed this

\footnotetext{
${ }^{42}$ Sarah Jane Edge, "Photographic History and the Visual Appearance of an Irish Nationalist Discourse 1840-1870," Victorian Literature and Culture, Vol. 32, No. 1 (2004): 17-39.

${ }^{43}$ Amy Martin, "Blood Transfusions: Constructions of Irish Racial Difference, the English Working Class, and Revolutionary Possibility in the Work of Carlyle and Engels," Victorian Literature and Culture, Vol. 32, No. 1 (2004): 84.
} 
degeneration in part to the Irish, but Engels, according to Martin moves beyond mere analysis of the situation. He suggested a "eugenics dimension” as he believed the Irish propensity for violence could be harnessed as a foundation for revolutionary politics. ${ }^{44}$ Martin’s thesis rests not in simply an internal class struggle, but instead presents a complex tapestry between the development of English working class identity and radical politics and discourses on Irish racial differences and immigration. This tapestry, she argues, was a clear indication that class conflict and possible revolutions were inseparable from questions of imperial security, race, immigration, and national integrity.

This nuanced analysis of the role of the periphery within the Empire is not of course limited to Ireland. Victorian society was developing an ideological concept of the 'other' not only toward the Irish, but to all non-English peoples in the Empire. In her work, Civilising Subjects: Metropole and Colony in the English Imagination 1830-1867, Catherine Hall explores this juxtaposition between the civilized English and the savage Jamaican. Her work reflects the complex and changing perceptions of race throughout the Victorian period, particularly as the African and Caribbean regions gained greater prominence within the larger imperial structure. ${ }^{45}$ Like Hilton, she examines the evangelical movement in Jamaica in the early to mid-1800s. Missionaries brought their ideas of emancipation to the island with the altruistic belief that slavery was wrong in the eyes of God. They argued that free men would and could prove as industrious as slave labor. They were correct, but as Hall points out, only to a point. As the freed slaves began to develop their own agendas, a backlash against the white presence on the island emerged. The tensions led to rebellion and, Hall argues, new racial policy to suppress the

\footnotetext{
${ }^{44}$ Ibid, 85.

${ }^{45}$ Catherine Hall, Civilizing Subjects: Metropole and Colony in the English Imagination 1830-1867 (Chicago: University of Chicago Press, 2002).
} 
very people the missionaries had emancipated years earlier. Hall’s analysis reflects a dynamic and changing racial perspective between both white colonizer and black colonized as power structures shifted and evolved in the colonial holdings.

Anne McClintock, in her work Imperial Leather: Race, Gender, and Sexuality in the Colonial Context, examines how the English created the identity of the other through the use of the media, particularly advertising, as she explores the definition of English in relation to the native identities across the Empire. ${ }^{46}$ Like Hall, she argues that the impact of imperialism was not a road that led only out from the center, but the colonies had a direct influence in shaping the metropole as well. The first half of her work focuses on the complex domestic circles of Victorian England. She argues that the modern Victorian woman was thrust into the narrow, confining role of housewife as the century progressed. The proper woman did not work, but instead maintained the domestic bliss and order of the home. Men idealized this image, but they found it sexually unappealing. The working class servants became the objects of illicit sexual fantasies and in some cases, realities for Victorian men.

The image of the working class woman, McClintock argues, was directly related to the colonial native. The second half of her work explores this connection between the rough-hewn washer woman of England and the African native thousands of miles from the metropole. They were both, McClintock posits, forbidden, exotic and readily available without question. This analysis places the colonized native in a subservient but sexually desirable position thus upending the traditional notion of pure repulsion and disgust for the other.

\footnotetext{
${ }^{46}$ Anne McClintock, Imperial Leather: Race, Gender, and Sexuality in the Colonial Context (London: Routledge, 1995).
} 
Dane Kennedy’s biographical analysis of explorer Richard Burton is a specific example of this nuanced conflict of racial identity in Victorian England. In his work The Highly Civilized Man: Richard Burton and the Victorian World, Kennedy provides insight into the overtly racist Englishman who nonetheless displayed a remarkable degree of cultural relativism for his time. ${ }^{47}$ Burton was, according to Kennedy, a master at cultivating his own image. He wanted English society to imagine him deeply unorthodox and anathema to Victorian values. Yet at the same time, the bad boy rebelling against the norms became one more source within a larger Victorian discourse about racial and cultural difference. Kennedy positions Burton as one voice in the greater socio-political framework of England. The nation was globally conscious and highly attuned to cultural, sexual, and religious differences. While radical for his outspokenness in a socially reserved society, Kennedy argues that Burton nonetheless echoed the contradictions and conflicts in the average, middle class Englishman of the period. Kennedy offers no explanation for these contradictions, but instead leaves it perhaps to the most fundamental of human nature. Victorian England, through the lens of Richard Burton, was a tumultuous, contradictory embodiment of the growing age of science, technology, imperialism and modernization.

While these three works are by no means the only ones to examine the complexities of empire and identity formation, they each serve as a cornerstone to the larger argument. Hall’s work focuses on white and black relations, McClintock analyzes the role of gender in the imperial power structure and Kennedy provides an individual example as a reflection of a larger body of social thought. These works also serve to

\footnotetext{
${ }^{47}$ Dane Kennedy, The Highly Civilized Man: Richard Burton and the Victorian World, (Cambridge: Harvard University Press, 2005).
} 
contextualize the Irish within the larger Empire as well. The dialogues on the Africans and Indians often mirrored that of the Irish. How then were the Irish unique in this vast racial discourse in Victorian England? What distinguishes the Irish racial question from any other European nation in light of the later ethnic tensions that evolved around the darker races?

The answer lies in the intersection of the long and tumultuous history between these two nations and the escalating problems of the 1800s. As Michael Hetcher argues, Ireland was England's first colonial holding. With the full support of the pope, Henry II invaded and staked a claim to Irish soil and its people in the 1100s. This led to a myriad of cultural and ethnic clashes that culminated in the Protestant Reformation. Once the religious divide became an intractable wall between the two nations, Catholic Ireland became a source of consternation, tension and anger for the English, with its heathen faith and its constant uprisings. This alone perhaps would not have been enough to prove so detrimental to relations between the English and Irish. As Amy Martin argues, however, the Irish were the first large-scale immigration of colonial subjects into England. There were a multitude of reasons, including the Great Famine as explored in Chapter Three, but no matter the reason, they came in record numbers into English urban centers. Carlyle and Engels both saw this immigration as a maelstrom leading to problems and potential disaster for England. This immigration, combined with the centuries of tension over land, political power and religion, led to the development of a distinctly anti-Irish sentiment in the Victorian Era.

This sentiment is unique among Europeans in that it was directed at an other not with extremely different physical features from that of the average Englishman, but just 
the opposite. Physically, the Irish shared a common Caucasian genetic origin with the English. The dark skin of the Africans, with their distinctly non-European features, could easily be classified as inferior as they were radically different. To Victorian England, Polygenesis seemed to have a legitimate scientific claim that these people were from another strain of humanity. The Irish also shared a history with the English dating back centuries with contact as early as the 400s between the Anglo-Saxons and the native Irish populations. What then were the Irish? Why did they fail to embrace the Protestant Reformation as England had? Why did they remain poor in spite of valiant attempts to raise their circumstances? Why did they fail to see the value in democratic traditions, such as the concept of liberty or education? These questions had no simple answers for the English, but as the waves of starving, disease-riddled Irish immigrants flooded English ports, the rate-paying middle class of England sought answers nonetheless.

\section{The Popular Press Responds}

The popular media of the time aimed to please this growing middle class of taxpaying citizens and the newspapers, magazines and books published a great deal on the many facets of the Irish question. This rhetoric paralleled, to a certain degree, the growing discourse on the racial issues surrounding the 'darker' of the species. In 1849, for example, Thomas Carlyle published an essay titled "Occasional Discourse on the Negro Question,” in the popular magazine Fraser's Magazine for Town and Country. He fervently argued that the Negro was unfit for freedom and that God wanted these people to remain in bondage to their white masters. ${ }^{48}$ This essay was published nine years after his anti-Chartist publication in which he railed against the Irish for these very same

\footnotetext{
${ }^{48}$ Thomas Carlyle, “Occasional Discourse on the Negro Question,” Fraser's Magazine for Town and Country Vol. XL, (London: February 1849): 527-538.
} 
character flaws. In 1849, Carlyle stressed that England was in danger and it was vital to “suppress Chartist riots, banish united Irishmen... and wait, with arms crossed, till black anarchy and social death devoured us also.”49 Carlyle’s language toward the white Irish was indistinguishable from that directed at the black natives of the West Indies or Africa.

It was this association that elevates Irish racism above merely squabbles between nations with differing viewpoints on socio-political issues, but it is disingenuous to make a direct parallel between white and black based on a limited number of sources, such as Carlyle's work. Just as the clash between Ireland and England was not one of binary opposites, racial distinctions were not neatly drawn either. In his essay "The Perversions of Inheritance: Studies in the Making of Multi-racist Britain,” Philip Cohen argues that the importance of the Irish immigrants rest in what they "unconsciously represent in and by the code of breeding” in "English race thinking.” According to Cohen, the Irish essentially encapsulated all that the English “most feared” by representing “a missing evolutionary link between the 'bestiality' of Black slaves and that of the English worker as well as dangerous currents in European thought, including republicanism.”50 Ambalavaner Sivanandan portrays the Irish as the fighting, aggressive faction of a larger subaltern "black” struggle within British society, thus placing them within a post-colonial analysis without singling them out as completely unique. ${ }^{51}$ In her work Imperial Leather, Anne McClintock acknowledges the difficulty in identifying racism without the clear marker of skin color. She instead argues that there were other distinctly racist attributes in

\footnotetext{
${ }^{49}$ Ibid, 528.

${ }^{50}$ Philip Cohen, “The Perversions of Inheritance: Studies in the Making of Multi-racist Britain,” in Multi-Racist Britain, eds. Philip Cohen and Harwant S. Bains (London: Basingstoke, 1988): 9-118.

${ }^{51}$ Ambalavaner Sivanandan, “Challenging Racism: Strategies for the 80s,” Race and Class 25, No. 2 (Autumn, 1983): 4.
} 
English representations of the Irish, such as barbarism and savageness. ${ }^{52}$ Luke Gibbons readily acknowledges that there is not a direct line connecting Irish racism with blacks, but in his essay “Race against Time: Racial Discourse and Irish History,” he defines a “model of racism” and then compares the Irish to the treatments of Native Americans. He believes these groups share a common "historical experience of being at the receiving end of the first systematic wave of colonial expansion." ${ }^{53}$ These historians reflect the argument that while Carlyle’s rhetoric may have been on the extreme end of public opinion, there was a significant degree of racism directed at the Irish people that was well beyond the normal international tensions of Europe at the time. Mary Hickman and Bronwen Walters suggest that rather than a direct parallel between anti-Irish rhetoric with anti-black racism, historians need to “deconstruct” the idea of “whiteness” as a homogeneous formation, thus placing the Irish well within the racial hierarchies of the era without oversimplifying attitudes and opinions. ${ }^{54}$

\section{Origins of Racial Discourse}

These racial hierarchies that emerged in the later decades of the 1800s were fueled by the misguided 'scientific' intellectualism of the time. Nancy Stepan and Michael Banton both trace the development of racial theories and the dubious science behind them during this era. Each scholar examines the intellectual evolution of these theories throughout the late 1800s. Both agree that the foundation of racial ideology essentially began with the development of Phrenology in the 1850s, and the extensive use of bodily measurements as cultural and intellectual markers. The link between racial

\footnotetext{
52 McClintock, Imperial Leather, 52-53.

${ }^{53}$ Luke Gibbons, "Race against Time: Racial Discourse and Irish History," Oxford Literary Review 13 (1991): 95-97.

${ }^{54}$ Mary J. Hickman and Bronwen Walter, Discrimination and the Irish Community in Britain: A Report of Research Undertaken for the Commission for Racial Equality (London, 1997), 11
} 
types and geography also emerged during this decade. Polygenism was used by some like Burton to explain the vast cultural, intellectual and physical differences English imperialists were encountering as they spread across the globe. Darwinism, later applied socially, began to establish a hierarchy of species, including Man himself. This evolved into racial categorization, physical anthropology, and finally the science of eugenics. Any race of humans deemed closer on the evolutionary scale to the ape was categorized as naturally inferior, and could therefore, be colonized and exploited. ${ }^{55}$

Science was then used to officially 'prove' the Celts were inherently inferior: physically, culturally, and intellectually. Socially weak, their culture was primitive because they lacked the intelligence to progress. They were intellectually incapable of self-responsibility in religious or civic affairs. Primary sources, including travel diaries, scientific journals, popular media, and monographs describe the Celt as impulsive, deceitful, and uncivilized. Scientists such as Robert Knox found the Celts peculiarly ugly, with features that clearly indicated poor breeding, a barbarous nature, and placed them among the inferior classes in the newly developing science of the categorization of races and species coming from Social Darwinist thinking.

During this scientific era, gender emerged as a form of classification and division as well as ethnicity. Masculinity was being more clearly defined during the 1800s, and part of that definition was the creation of an other in contrast to one's own identity. Men

\footnotetext{
${ }^{55}$ Nancy Stepan, The Idea of Race in Science: Great Britain, 1800-1960 (Connecticut: Archon Books, 1982), 8; Michael Banton, Racial Theories (Cambridge: Cambridge University Press, 1987). See also: Christine Bolt, Victorian Attitudes to Race, (London: Routledge, 2006); Edward Beasley, The Victorian Reinvention of Race: New Racisms and the Problem of Grouping in the Human Sciences, London: Routledge, 2010).
} 
create the ideal definition of masculinity in part by what men are not. What men are not is then defined as feminine and relegated to an inferior status in order to bolster the position of the masculine identity. English national identity, according to the theories of masculinity put forth by John Tosh, became a complex combination of social constructions. Victorian males constructed a definition of masculinity based on respectability, physical fitness, ethics, and patriotism. This dominant masculinity was also constructed from what it was not, and this was accomplished by denigrating both subordinate forms of masculinities and anything deemed feminine. ${ }^{56}$ These subordinate masculinities, defined through the new sciences of the era, were clearly to be found among the colonial subjects of the Empire. Not only were the colonial subjects subordinate as men, their cultures and national identities were often labeled as feminine, marking them with even greater inferiority. The Celts, for example, were often described as delicate, soft, and possessed of a nervous temperament; traits associated with the Victorian woman and inferiority.

These ideologies combined to create a complex and contradictory system of degradation throughout the empire. According to many popular images in the press, the Irish, who were both violent and weak, savage and soft, took on an inferior, sub-status in the social hierarchy. Historians such as Tony Crowley and L.P. Curtis have analyzed the images found in the popular press in the later decades of the 1800s and they argue that the perspectives became more harsh as the century progressed. ${ }^{57}$ As early as the 1850 s,

\footnotetext{
${ }^{56}$ John Tosh, Manliness and Masculinities in Nineteenth-Century Britain: Essays on Gender, Family and Empire (London: Pearson Longman, 2005), 42-49.

${ }^{57}$ Tony Crowley, The Politics of Language in Ireland 1366-1922: A Sourcebook (London: Routledge, 2000); Tony Crowley, War of Words: The Politics of Language in Ireland 1537-2004 (Oxford: Oxford University Press, 2005); L. Perry Curtis, Apes and Angels: Irishman in Victorian Caricature (London: David and Charles, LPC, 1971); L. Perry Curtis, Anglo-Saxons and Celts: a Study of Anti-Irish Prejudice in
} 
English magazines and newspapers began depicting the Irish, and other inferior races, in increasingly degrading ways. Social Darwinism, as it came to dominate the social and scientific thought of Europe, gave the English a new platform from which to create divisions. The inferior Celts were then classified according to their proximity to the ape based on the theory of evolution and Darwin's theory of natural selection. Political cartoons, as a consequence, began to 'simionize’ the Irish. The magazine Punch was famous for its depictions of the Irish ape-man. This degradation could then be used to serve any purpose as needed, including marginalizing the Irish from the social welfare system of England.

\section{Primary sources and methodology}

The role of the popular media in relation to the people of England is essential in understanding this shift in attitude toward the Irish. While the press and public opinion are of course, not synonymous, print journalism had, by the mid-1800s, become a staple in the lives of the middle class English. The middle class represented the largest ratepaying group in England. They were citizens with full voting rights, not subjects like the Irish or English working class, and they were increasingly expressing their opinions and influence in the political arena. In the wake of the 1832 reforms, a strong sense of competition developed among the political factions and the middle class benefited. Wealthy politicians courted their favor in order to win and maintain control over Parliament. This bourgeoisie turned to the media for information and more importantly, the interpretation of the information as they became increasingly involved with the affairs of politics and policy.

Victorian England (Washington DC: Smithsonian Press, 1968); Also see: Laurel Brake and Julie F. Codell, Encounters in the Victorian Press: Editors, Authors, Readers (New York: Palgrave Macmillan, 2005). 
Throughout the 1830s and 1840s, this class of English society became a powerful socio-political force as they achieved political self-awareness. The fight against the Corn Laws and Chartism are two examples of middle class influence on political issues. The media was integral in shaping and reflecting their opinions as a new consumer culture drove the popular press. This press included magazines, books, newspapers, and pamphlets. It was by no means homogenous as both liberals and conservatives inundated the public with material. What cannot be disputed is the sheer volume of material available to the middle class readership. By mid-century, newspapers such as The Times were nationally recognized with a daily circulation of over 40,000 by 1850 . One-third of the circulation was outside the metropolitan area. This does not, however, accurately reflect the paper's readership as libraries and reading-rooms were popular during this period. Provincial papers, such as the Manchester Guardian, frequently reprinted articles from the national paper as well. ${ }^{58}$ Competitors to The Times included the Morning Chronicle, The Daily News, The London Illustrated News, Punch, and hundreds of local newspapers.

In addition to the daily and weekly newspapers, magazines, books, and pamphlets flooded the market and covered everything from literature to scientific developments. Journalists of the Victorian Era were not contracted to specific newspapers and many wrote for multiple media outlets. Gilbert à Beckett, for example, not only wrote for Punch, but he was a lead writer for both The Times and The Illustrated London News. This crossover and the continued practice of article reprints meant that in spite of the vast quantity of material, dominant media perspectives were filtered to the middle class in a

\footnotetext{
${ }^{58}$ Peter Gray, "British Public Opinion and the Great Irish Famine 1845-49," Comhdhail an Chroaibhin: conference proceedings, ed. B. O'Conaire (Ireland: Irish Academic Press, 1995), 56.
} 
repetitive and consistent fashion thus allowing newspapers, magazines, and other print material to heavily influence public opinion.

Bernard Lightman, in his work Victorian Popularizers of Science: Designing Nature for New Audiences, adds another dimension to the influence of popular media, particularly in the spread of the sciences and pseudo-sciences of the day. He focuses his analysis on the role of the non-scientific writings that interpreted the technical language for the public. The journalists and amateur writers of the time put a layman's 'spin' on the new developments of the day as 'real' scientists were slow in accepting the popular press as an outlet for their scholarly works. Lightman points out the popularity of books from John Henry Pepper and John George Wood that included extensive visuals in order to capture the imagination and attention of the larger public. Arabella Buckley and Grant Allen embraced Darwinism and published works supporting evolution. Richard Procter began publishing his amateur journal Knowledge as a counterpart to the more scientific publication Nature. As publishers, not scientists, determined what books were published, Lightman argues that those works aimed at the masses, and thus would ensure a profit, were released regardless of their scientific merit. The journalists in the press and the amateurs of the book publishing world were, therefore, highly influential in not only bringing the latest scientific knowledge to the public, but also in interpreting, correct or not, how the public understood that knowledge. ${ }^{59}$

This dissertation relies on a broad sampling of printed material as a reflection of the scope and depth of middle class English attitudes from the 1820s through the 1860s. With the vast quantity of material available during the Victorian Era, it is impossible to

\footnotetext{
${ }^{59}$ Bernard Lightman, Victorian Popularizers of Science: Designing Nature for New Audiences (Chicago: University of Chicago Press, 2007).
} 
accurately represent every opinion from the popular press. This work concentrates on the larger regions of England from 1820 through 1870. Irish immigration was highest in those areas, such as Manchester, Liverpool and London. The Irish presence in those regions had a more direct impact on the middle classes and, therefore, the issues were more of a focus for the media. In order to assess the spread of sentiments toward the Irish, works from other regions such as Preston and Newcastle were also consulted as invaluable as points of comparison. The monographs consulted reflect those works in widespread publication, often with several reprinted editions to indicate their popularity during that era. Thomas Carlyle's work Chartism, for example, went through two editions and his articles were often reprinted in both magazines and separate pamphlets. Another example, Charles Dickens, was among the most popular authors of the period with his works serialized in magazines and later published as complete novels. The evidentiary works consulted for this study are designed to reflect a popular zeitgeist of the Victorian Era in order to frame the governmentality that emerged in the 1850s and 1860s. They do not, of course, represent every individual Irish or English opinion, but instead serve as a broad overview of the socio-political climate among middle class England.

A special note must also be given to travel diaries. They were a popular form of expression in the Victorian Era, but those produced during the Famine years differ greatly from the general body of such material. This sub-genre often contained overt and deliberately political opinions. There were two distinct agendas, pro-Irish and anti-Irish, but remarkably, there are common characteristics to works serving both agendas. The authors not only chronicled the devastation and death, but they sought to uncover the causes and consequences of the Famine. The details of the crisis are strikingly similar in 
description as well, countering the possible accusation of distorting facts to serve an end goal.

While their conclusions were radically different, their arguments and perspectives pushed these journals into the socio-political discourse of the Famine and shaped public opinion not only of the Famine, but also government, landlord and personal responsibility. ${ }^{60}$ These authors did not shrink from controversial details, emotional appeals, or personal opinions. S. Godolphin Osbourne, a Protestant minister for example, clearly stated that his goal was to encourage as many travelers as possible into the remote regions of Ireland so that "anything might be done” because from his perspective, humanity had become so "taxed, that it has become blind to anything, which might increase its burden." ${ }^{61}$ These sources are thus invaluable in analyzing the major arguments that were filtering down to the middle class reader through these published journals.

\section{Sources reflecting the changing perceptions}

Although statistically the number of immigrants as compared to the total population of England was small, the fear of these strangers congregating in the cities grew disproportionately. Two publications, the 1832 work from Dr. James Phillips Kay entitled The moral and physical condition of the working-class employed in the cotton manufacture on Manchester and the 1836 Report on the State of the Irish Poor contributed significantly to this fear of the Irish as outsiders long before the massive waves of famine immigrants reached English shores. Dr. Kay's work was a pamphlet highlighting the conditions of the poor in Manchester, particularly the Irish as those

\footnotetext{
${ }^{60}$ Gillian Ní Ghabhann, "A Critical Examination of A Selection of Travel Writing Produced During the Great Famine,” Chronicon, (1997): 1.

${ }^{61}$ S. Godolphin Osbourne, Gleanings in the West of Ireland, (London: 1850), 78.
} 
neighborhoods where they lived were among the most poverty-stricken. He made a number of observations on their squalid living conditions during his battle against the cholera epidemic of the 1830s in the poor neighborhoods throughout the city. He argued that the Irish "have taught the labouring classes ... a pernicious lesson [of] demoralization and barbarism." ${ }^{62}$ While the Irish were not the only poor people living in such conditions, this work set a precedent for the image of the immigrant as diseased and degenerate. They were a blight on society, lowering the standards of the hard-working Englishmen around them. ${ }^{63}$ The Report on the State of the Irish Poor was a Parliamentary report not only on the Irish in Ireland, but also those in England. The report echoed Dr. Shuttleworth’s findings. ${ }^{64}$ The Parliamentary reports, often reprinted in newspapers and magazines, defined the political perspectives of the period that filtered down to become the social perspectives. These reports, combined with the popular media sources, best reflect the opinions that were filtering down to the middle class of England.

As the Irish population in England continued to rise, fear of their presence became more concrete. The Irish were willing to work for lower wages, and thus provided competition for the English working-classes in the industrial centers. Most of these new immigrants settled into low-skilled or semi-skilled employment, such as bricklaying, roadmaking, and dock labor. ${ }^{65}$ According to English economist Robert Griffen, the yearly income in Ireland during the mid-1800s was less than one-seventeenth that of the average

\footnotetext{
${ }^{62}$ Dr. James Phillips Kay Shuttleworth, The Moral and Physical Condition of the Working Classes Employed in the Cotton Manufacture in Manchester, Second edition (London: Frank Cass and Co. Ltd., 1970), 21. This work was originally published in 1832 in response to a cholera epidemic in the city.

${ }^{63}$ M.A. Busteed and R.I Hodgson, "Irish Migrant Responses to Urban Life in Early Nineteenth-Century Manchester,” The Geographical Journal, Vol. 162, No. 2 (July: 1996): 141.

${ }^{64}$ Great Britain, Report on the State of the Irish Poor (London: G. Luxford, 1836).

${ }^{65}$ Robert Miles, Racism and Migrant Labour (London: Routledge, 1982), 129.
} 
income of England. ${ }^{66}$ The low wages in the English cities were considered an improvement compared to the standards in Ireland, and these jobs provided an attractive alternative to starvation at home. As the influx continued in the industrial regions, competition increased and the fear among the English of job displacement became more acute.

This real fear concerning employment and labor issues fuelled growing discrimination against the Irish. The superior Anglo-Saxon was, as commentators put it, being driven from his work by a clearly inferior, savage people. In order to combat this encroachment, the violent nature of the Irish other was exposed and translated into another very real threat, the criminal. A portion of the 1836 Report on the State of the Irish Poor reflected upon the criminal nature of the 'Paddy' immigrant. ${ }^{67}$ Similarly, an 1839 report from the Constabulary Commission recorded a Salford Gaol prisoner’s statement that "Manchester and Birmingham turn out more thieves than London and Liverpool,” but the unnamed prisoner stressed that the Manchester and Liverpool criminals “are reckoned the most expert” because they were "thought to be of Irish parents.”68 Between 1841 and 1871, 30 percent of all arrests for assault on a police officer in Manchester were Irish, an overrepresentation of 1.9 percent as compared to the entire population of the city. ${ }^{69}$ By 1887, The Times of London reported that 20,232

\footnotetext{
${ }^{66}$ Robert Griffen, “The Economic Value of Ireland,” The Nineteenth Century: A Monthly Review, No. 109 (March, 1886): 334

${ }^{67}$ Great Britain, Report on the State of the Irish Poor, appendix II (London, G. Luxford, 1836): 1920.

${ }^{68}$ Great Britain, Report of the Constabulary Commission, 18 S (London, G. Luxford, 1839): 27.

${ }^{69}$ William J. Lowe, The Irish in Mid-Victorian Lancashire: the shaping of a working class community, (New York: P. Lang, 1989), 102.
} 
criminals, 11.39 percent of all criminals in England, were Irish-born. ${ }^{70}$ The sentiment of

The Times was simple, "take away the Irish immigrants and there would be less crime.”71

\section{Chartism}

English perspectives on the violent nature of the Irish were shaped by Irish involvement in the Chartist Movement. As the nationalist movement spread in Ireland and came to England with the immigrants, the Chartists in Britain seized the opportunity to entice the lower class Irish into their working class movement. The movement began connecting its goals to those of Ireland. The Irish, the Chartists argued, could achieve two goals through Chartism: promote their nationalist mission through the traditional rhetoric of popular constitutionalism and secondly, successfully improve their working conditions and social status in England. The Irish in Ireland had yet to solidify their fierce opposition to English rule. The nationalist movements instead often focused on greater equality of land ownership and working conditions for the natives; the very goals espoused by the Chartists in England for the working classes there. On both sides of the Irish Sea, the politically active Irish wanted equal status with the English. The Act of Union, they believed, placed Ireland within the political structure of the United Kingdom and Irish citizens were, therefore, no different from the Scots, the Welsh, the English or any other group. Religion, they argued, should not be used as a basis for exclusion for any member of the greater United Kingdom. The Chartist movement and its central belief that in a 'civic’ nation like Britain, the venerability of common law and constitutional freedom defined the nation's identity and position as a pre-eminent western power. These ideals thus provided the Irish nationalist movement with a framework for its demands. Chartists

\footnotetext{
70 “Irish Crime,” The Times, June 211887.

${ }^{71}$ Ibid.
} 
and Irish alike argued that political debate should center on issues of constitutional liberty and the rule of law. ${ }^{72}$ The radicals of the Chartist Movement did not contest this national identity; they instead fought for its guardianship as the most true and loyal patriots standing against European absolutism.

The Chartists argued that, enshrined in the myth of the British constitution, were the rights of the free-born Englishman to civil and religious liberty. These rights, they stressed, should be extended to all peoples throughout the United Kingdom, and this ostensibly included Ireland through the Act of Union. Popular constitutionalism was, therefore, a language of inclusion, seeking to secure full political citizenship for all adult males throughout the United Kingdom, including Catholics. Chartists also sought to improve social conditions in Ireland as a way to stem the tide of emigration. These policies eventually attracted large numbers of Irish to the Chartist ranks. As the Chartists were viewed as a serious threat to national security, this threat was quickly transposed onto the Irish immigrant population.

As the Chartist movement grew in strength, the connections with the Irish immigrant community solidified. Irish issues, such as greater political inclusion for Catholics, now became a facet of the political doctrine of the movement. Although the Catholic Emancipation Act had been passed years earlier, the Chartists wanted to continue to expand civil rights for Catholics. While the act did allow Catholics into Parliament, it also increased the voting requirements, thus disenfranchising many of the Irish poor that the Chartist movement now included. The Irish Confederates, deeply nationalist and a growing political force, were no longer willing to respect the restrained, political path that leading Irish Catholic politician Daniel O’Connell had preached for

\footnotetext{
${ }^{72}$ Anthony Smith, Ethnic Origins of Nations, (London: Wiley-Blackwell, 2009), 148-149.
} 
many years. They were determined to end their subordinate status by any means necessary. The Young Ireland movement, a more militant group who broke away from the Irish Confederates, took a more aggressive stance toward Irish issues, such as the repeal of the Act of Union. Chartism, with its politics-in-the-streets methodology, gave the Irish rebels an organized movement for their revolutionary zeal.

Information on the activities of the Chartists reflects this perception of threat. Although Chartism struggled to gain a foothold in Liverpool, Chartist activities nevertheless occupied the largest single file in the Home Office Disturbance Papers for 1848. According to the media, the April mass meeting in Kennington Common, held in 1848 just after the Paris revolution, turned chaotic and violent, another indication of the subversive nature of Chartism. Reports of the event were damning, portraying the movement as criminal, unconstitutional, un-English, and distinctly Irish in makeup. That morning, The Times published a warning to its readers, declaring the entire Chartist movement was a "ramification of the Irish conspiracy." The rebels, according to the report, wanted to make "as a great a hell of this island as they have made of their own.,"73 Other publications continued to directly associate the Irish with the Chartist platform and violence as well. As the media continued to link the Chartist movement with both violence and Irish immigrants, fear spread among the English middle and working class. This was a fear not only of a political position, but fear of a particular population within the borders of England. The Irish were a danger to English society, and the activities surrounding the failed Chartist movement seemed a powerful confirmation of that stereotype.

\footnotetext{
${ }^{73}$ The Times, April 10, 1848.
} 


\section{The Great Famine and Immigration}

At the same time, the Irish became more connected to the growing turbulence of Chartism, the Great Famine struck Ireland with devastating consequences on multiple levels. As millions died or fled the country, England was faced with a very difficult decision. How could one nation save another? Should one nation save another? What was England's responsibility to Ireland? After the Act of Union, Ireland was technically a part of the United Kingdom. How responsible was England in light of the political connections between the nations? What exactly was Ireland's status in the political and economic framework of the United Kingdom? Initially the crisis was seen as a short-term problem, but as the potato crop continued to fail, it became clear that solutions were needed. Sir Robert Peel's government allowed Adam Smith's concept of the free market to dictate policy and Sir John Russell's government changed very little when it came to power in the late 1840s. Starvation spread across the island with the crisis reaching its peak in 1848, Sir Charles Trevelyan, the assistant secretary to the Treasury, declared an end to the famine. The Young Ireland movement rebelled, however, and serious outbreaks of violence, including murder, were committed across the island as the death toll rose. Immigration to England climbed steadily during this period, and the English, weary from charity and taxation and enraged by the increasing violence and apparent ingratitude, began to view their neighbors with a growing sense of hostility. This period was thus a defining moment in the history of Anglo-Irish relations in the nineteenth century. 
In the wake of the growing sense of failure to end the famine, the English press, while hardly enlightened, began to focus a significant amount of attention on the sufferings of the Irish and reflected a genuine desire to ameliorate them. Richard Lebow’s observation that "it rarely occurred to the Englishmen that many of these alleged traits [of the Irish] might be the result, not the cause, of poverty;” is patently false in the context of the period $1840-1845 .^{74}$ For the decade after the famine, however, the statement has some relevance. By the 1850s, reforming the Irish and easing their suffering was no longer a priority for Parliament. Instead, separating them from the English, particularly English workers, controlling them effectively, and making use of their land moved into the forefront of the English agenda as presented by the media.

This agenda served the middle class well. If they could be marginalized as biologically poor, isolated from the English laborer and removed from the social welfare system, the middle tax burden would be eased without guilt over sparing charity to the needy of England. Ireland had the support of a portion of the English, from the working class of the Chartist Movement to individuals such as John Stuart Mill. Economist George Wakefield and Thomas Foster, like Mill argued fervently for investments in reconstructing Ireland to make it a viable nation. Irish politicians such as Daniel O’Connell spoke eloquently about the Irish in Parliament and the press and brought a humanity to the suffering of a people an ocean away. These impassioned voices were not powerful enough however. As the English middle class grew tired of the Irish woes, the negative press fit their preferred interpretation of the knowledge being given to them.

\footnotetext{
${ }^{74}$ Richard Lebow, White Britain and Black Ireland: the influence of stereotypes on colonial policy (New York: Institute for the Study of Human Issues, 1976), 40.
} 
The view of the Irish people that emphasized the permanence of their character and condition was, therefore, critical in this middle class interpretation to serve their agenda. Their misfortunes were no longer seen as the product of past mistakes, but were instead the nature and destiny of the Irish themselves. Keeping them happy, not reforming them, was of the essence; for the failure of what was assumed to have been the great experiment of liberalism during the famine had demonstrated the futility in the attempt to raise them to an English standard of civilization. Ireland was no longer part of the United Kingdom as the Act of Union once implied, but colonial, and the Irish were biologically doomed to remain in poverty and ignorance. They were not, therefore, the responsibility of the English ratepayer.

The interest and optimism with which the English regarded Ireland in the first half of the 1840s was wholly absent in the two decades following the famine, during which the legislative inertia that marked the Palmerston administrations from 1855 to 1865 was not peculiar to Ireland but extended as well to English domestic policy. At the same time, it is clear that there was little public pressure for reform in Ireland until after the Fenian agitation of the late 1860s brought the issue of Irish poverty once again to the fore. Unlike the English reaction to the repeal agitation of the 1840s, which had remained fundamentally optimistic despite fears of an Irish rising, the response to Fenianism was remarkably savage - reflecting the differences in climate between the 1840 s and the 1860s.

\section{Chapter Analysis}

The story of Anglo-Irish relations began centuries prior to the 1800 s with the Norman Invasion under the command of Henry II. This story, rife with conflict, escalated 
in the 1800s with the Act of Union, the measure that officially absorbed Ireland into the United Kingdom. The Irish were now subjects of the Crown, but without the basic rights of the English, such as sitting in Parliament. In the 1820s, the Catholic Association and Daniel O’Connell took up the fight against those injustices and with the Catholic Emancipation Act under the influence of Whig Enlightenment ideals, this minority group re-established itself as a socio-political force. Emancipation led to greater freedoms for the Irish population in England and also helped usher in a period of political movements for universal freedom through the Chartist movement.

Chapter one will explore the lengthy and complex history between England and Ireland from the earliest period to the pre-famine decade of the 1830s. It will examine the troubling impact of the Act of Union, and the growing political power of the Irish on both sides of the Irish Sea. England also experienced an influx of Irish immigrants in these early years, and while nothing to the degree of the 1840s, these newcomers nonetheless had an impact on English socio-political thought. These were the critical decades that were to lay the foundation for the later crisis of the famine and the shift from a paternal superiority in attitude to one of open hostility toward the Irish in the later part of the century.

Chapter two of this work will analyze the role of the Irish within the radical movements of the 1830s and 1840s and how those roles were interpreted by the English. These movements played a crucial part in the general state of unrest and revolution spreading throughout Europe during this period. Chartism in particular, as the forerunner of the radical groups, launched a powerful attack on the status quo of English society and politics. This movement, under conflicting leadership, often took its causes to the street 
and created a growing sense of unease among the English middle class. The fear of violence was pinned on the Irish faction of Chartism in the north, adding a hateful face to the immigrant community the English once thought of as simple peasants.

Using these early perceptions as a framework, chapter three will focus on the Great Famine as the critical event in redefining Anglo-Irish relations. This volatile period created a disastrous situation in Ireland. Responses in England varied from paternal charity to harsh criticism of the Irish themselves, and these varied responses began to shape English perceptions. As the charitable viewpoint drifted out of favor, a series of violent uprisings and murders rocked the press in England. Once again, the simple peasant proved his savage, ungrateful nature, and the harsh criticism became the social norm.

Once the famine became an entrenched reality across Ireland, the people began leaving in record numbers to various ports around the world. England, because of its proximity was the most frequent destination. Chapter four will analyze the immigration patterns into England and the effect the new immigrants had on the larger English population. The Irish built communities within major urban areas that became riddled with poverty, disease, and crime. This reality played a vital role in the developing perceptions of the English as well as the prejudices of the times.

Chapter five will break down these new English perceptions of the Irish in the immediate post-famine decades and the social changes that influenced these perceptions. This image developed not only from the major socio-political events throughout the century, but it was also influenced by the science of the day. Various forms of pseudoscience emerged in the mid-1800s, including phrenology, and by the later Victorian 
period, Social Darwinism became a tool for constructing racial hierarchies as well as classifications for the animal kingdom. Using the scientific developments as a lens, chapter five will highlight the new image of the Irish people in the later decades of the period. Chapter five will also analyze the rationale for this new image from a middle class perspective based on a very real economic pressure on the ratepayers of England.

The relationship between England and Ireland has been a complex and violent one dating back to the 1100s with the Norman invasion. By the early 1800s, England dominated its neighbor and had developed a paternalistic superiority toward the native people. Three key events, the Chartist movement, the famine, and the subsequent immigration all served as catalysts of change toward a more negative perception of the Irish. These events, fueled by the science of the day, defined the people of Ireland in severe, harsh tones that excluded them from the framework of civilized society. The empire had essentially created two identities, that of English and that of the other, and these two identities could not co-exist equally within England during the second half of the century. This study is an analysis of a specific relationship between the English and the Irish that developed internally from the early 1800s through the 1860 s 


\section{Chapter One}

\section{Prelude to the Victorian Period}

Until the 1100s, Ireland and England remained largely isolated from one another, divided by the Irish Sea and differing socio-political institutions. ${ }^{1}$ Although there was a recorded invasion from an expeditionary force sent by Northumbrian King Ecgfrith in 684, they apparently did not stay in Ireland for long. After the fall of Rome, England struggled to unify itself under a single ruler and Celtic Ireland slowly evolved into a Christian kingdom as an independent entity from its neighbor.

Both regions dealt with Viking invasions over the centuries. The first raid recorded in Irish history occurred in 795 when Vikings from Norway looted the island. Early Viking raids were generally small in scale and quick. These early raids interrupted the golden age of Christian Irish culture and started roughly two hundred years of intermittent warfare, with waves of Viking raiders plundering monasteries and towns throughout Ireland. By the early 840s, however, the raiders began to establish settlements along the Irish coasts and to spend the winter months there. In 852, the Vikings landed in Dublin Bay and established a fortress. After several generations a group of mixed Irish and Norse ethnic background arose, giving rise to the earliest ethnic distinction GallGaels, translated as foreigner in ancient Gaelic. Despite establishing settlements, particularly along the coastline, the Norsemen never achieved total domination of Ireland as they often vacillated between fighting for and against various Irish kings. The Battle of

\footnotetext{
${ }^{1}$ The roughly 800 years from the early Viking period to the Act of Union is vital to understanding the development of English and Irish relations. Key events shaped and dictated colonial policy and attitudes over the centuries and I have addressed those touchstone periods in order to establish the long and complex connection between the two nations. The historiography, however, is vast and cannot be thoroughly examined in this work. I have provided key sources only as an introduction to each period and make no claims as to the extensive and diverse historical analysis for each area I examine in the broader narrative.
} 
Clontarf in 1014 marked the beginning of the decline of Viking power in Ireland and less than a century later, the Normans would arrive to change the face of Ireland permanently. By the twelfth century, Ireland was divided politically into a shifting hierarchy of petty kingdoms and over-kingdoms. Power was exercised by the heads of a few regional dynasties vying against each other for supremacy over the whole island. The Irish annals describe frequent assassinations, clan warfare, and familial dissent. ${ }^{2}$

The infighting reached a new plateau when King Diarmait Mac Murchada of Leinster was forcibly exiled by the new High King, Ruaidri mac Tairrdelbach Ua Conchobair of the Western kingdom of Connacht. Fleeing to Aquitaine, Diarmait obtained permission from Henry II to recruit Norman knights to regain his kingdom. The Annals of Ulster reported that "Diarmait Mac Murchadha came from over sea" in the year 1167, followed by the main forces of Normans, Welsh and Flemings. ${ }^{3}$ Several counties were restored to Diarmait's control, when, according the Annals of Ulster, the "fleet of Robert FitzStephen came to Richard de Clare, known as Strongbow, heir to his kingdom and the Leinster king” who had sought help from the foreigners. ${ }^{4}$ Strongbow's succession caused a great deal of consternation for King Henry II of England, who feared the establishment of a rival Norman state in Ireland. Accordingly, he resolved to establish his authority across the island in a more direct way.

\footnotetext{
${ }^{2}$ The Annals of Ulster alone provide ample evidence. In one year alone, 1105, Conchobor son of Mael Sechlainn, heir designate of Temair, was killed, an army was brought by Muirchertach ua Briain, and he expelled Donnchad ua Mael Sechlainn from the kingship of the west of Meath, and Niall Odar ua Conchobuir was killed. The year 1111 was little better with the towns of Lugmadh, Port Láirge, and Cenannas all burned in a one month period and "Donnchad ua Anluain, king of Uí Nialláin, was treacherously killed by his kinsmen, and those kinsmen themselves were killed within twenty nights by the Uí Nialláin to avenge him.” The Annals of Ulster, trans. Mac Airt \& Mac Niocaill, T100001A (The Corpus of Electronic Texts, 2000), U1105.5, U1111.1: 545, 551. The annals were medieval chronicles of events, often on a local level. There are numerous collections from medieval Ireland, although most are in fragments.

${ }^{3}$ The Annals of Ulster (The Corpus of Electronic Texts) U1167.6: 157.

${ }^{4}$ Ibid, U1171.1: 167.
} 


\section{The Norman Invasion}

The papal bull Laudabiliter from Adrian IV gave Henry II the authority to bring Ireland back under the control of the proper Church authority of Rome. The king landed with a large fleet at Waterford in 1171, becoming the first King of England to set foot on Irish soil. The Annals of Ulster reported that "Henry (son of the Empress), most puissant king of England and also Duke of Normandy and Aquitaine and Count of Anjou and Lord of many other lands” arrived with "240 ships” and that this "was the first advent of the Saxons into Ireland.” The reports also indicated that he travelled the country receiving pledges from those loyal to the crown. ${ }^{5}$ Henry awarded his seemingly secured Irish territories to his younger son John with the title Dominus Hiberniae, or Lord of Ireland. When John unexpectedly succeeded his brother as King John in 1199, the lordship fell directly under the English Crown. ${ }^{6}$

Initially the Normans controlled the entire east coast, from Waterford up to eastern Ulster and penetrated deep into the western countryside. The counties were ruled by many smaller kings, who all swore their loyalty to the English monarch. The first Lord of Ireland was King John, who visited Ireland before he became king in 1185 and again during his reign in 1210. He helped consolidate the Norman controlled areas, while at the same time ensuring that the many Irish kings swore and maintained fealty to him. It was during this period that the first Irish Parliament was called in County Kildare, but it was a marginal body with very little influence as it was strictly an administrative organ of the Crown.

\footnotetext{
${ }^{5}$ Ibid, U1171.10,U1172.8: 167.

${ }^{6}$ Edmund Curtis, A History of Ireland from Earliest Times to 1922 (New York: Routledge, 2002), 39-40.
} 
In spite of the oath of loyalty to the crown, fear of an Irish-Norman uprising lingered and measures were implemented to maintain the supremacy of the English crown. Months after his arrival in Ireland and the extensive pledges of loyalty, Irish annals were still referring to Henry as the "King of the Saxons" and his supporters as "people of the king of the Saxons."7 Throughout the thirteenth century the policy of the English kings focused on weakening the power of the Anglo-Irish Lords in Ireland. King John, for example, encouraged Hugh de Lacy to destabilize and then overthrow the Lord of Ulster, and then granted de Lacy the coveted title. The Hiberno-Norman community also suffered from a series of invasions that hindered and eventually stopped the spread of their power. Politics and events in Gaelic Ireland served to draw the foreign settlers deeper into the orbit of the Irish as the divide between English and native widened.

By 1261 the weakening of the Normans had become manifest when Fineen MacCarthy, a native Gaelic lord, defeated a Norman army at the Battle of Callann. The war continued between the different lords and earls for about 100 years, causing a great deal of destruction, especially around Dublin. In this chaotic situation, local Irish lords won back large amounts of land that their families had lost since the conquest and held them after the war was over. Now England no longer had to worry about the power of the Norman lords, but of the ever increasing power of the Gaelic lords as well. These conflicts were helped by the arrival of the Black Death in 1348. Because most of the English and Norman inhabitants of Ireland lived in towns and villages, the plague hit them far harder than it did the native Irish, who lived in more dispersed rural settlements. After it had passed, Gaelic Irish language and customs came to dominate the country again. The English-controlled territory shrunk back to a fortified area around Dublin

\footnotetext{
${ }^{7}$ The Annals of Ulster, U1172.1: 173.
} 
known as the Pale, and had little real authority outside its borders. Many of the old Norman lords that remained became absorbed into the native Gaelic culture and the Pale stood out as a distinctly English entity in a Gaelic nation.

\section{Shifting Power Structures in Ireland in the 1400s}

By the end of the fifteenth century, central English authority in Ireland had all but disappeared. England's attentions were diverted by the Wars of the Roses and the Lordship of Ireland was handed over to the powerful Fitzgerald family clan leader, Earl of Kildare, who dominated the country by means of military force and alliances with many of the lesser lords and clans around Ireland. Around the country, local Gaelic lords and those lords who had been absorbed into the native culture expanded their powers at the expense of the English government in Dublin. The introduction of Poynings' Law in 1494, however, began the slow shift back toward English domination over the island. According to this act, the Irish parliament was essentially put under the control of the Westminster parliament, thus stripping it of any real, independent power over Irish affairs. It no longer had the authority to convene or pass legislation without the consent of the Irish and English Privy Councils and both councils had the authority to review and veto all bills as well. ${ }^{8}$

\section{Changes under the Tudors}

The Tudor involvement in Ireland began in 1536 when Henry VIII decided to reconquer Ireland and bring it under crown control. Over the decades, the Fitzgerald dynasty of Kildare had become very unreliable as allies of the Tudor monarchs. They had invited Burgundian troops into Dublin to crown the Yorkist pretender, Lambert Simnel as

\footnotetext{
${ }^{8}$ For a thorough analysis of the long-term affect of Poynings' Law on the Irish constitution and the evolution of law across the island see: James Kelly, Poynings' Law and the Making of Law in Ireland 1660-1800 (Dublin: Four Courts Press, 2007).
} 
King of England in 1487. Thomas Fitzgerald then went into open rebellion against the crown in 1536. Having put down this rebellion, Henry VIII resolved to bring Ireland under English government control so the island would not become a base for either future rebellions or foreign invasions of England. His first step was to upgrade Ireland from a lordship to a full kingdom in 1541. Henry was proclaimed King of Ireland at a meeting of the Irish Parliament that year. This was the first meeting of the Irish Parliament that included both the Gaelic Irish chieftains and the Hiberno-Norman aristocracy, and thus the power of the native Gaelic lords was still recognized at this point.

With the institutions of government in place, the next step was to extend the control of the English Kingdom of Ireland over all of its claimed territory. This took nearly a century, with various English administrations in the process either negotiating or fighting with the independent Irish and Old English lords. The re-conquest was completed during the reigns of Elizabeth and James I, after several extremely brutal conflicts. One of the most significant, the Desmond Rebellion in the province of Munster, led to the destruction of an entire dynastic family. The Earl of Desmond, head of the FitzGerald dynasty in Munster, and his followers, the Geraldines and their allies, rebelled against the extension of power from the Elizabethan government over the province. The Gaelic Earl fervently resisted this encroachment into his territory and demanded that the feudal lords remain independent from their monarch. Regional control was not the only issue, however, as religious antagonism between the Catholic Geraldines and the Protestant English state also factored heavily into the growing crisis as it had from the early days of the plantation policy. With the destruction of the Gaelic lords of Munster, 
the region was resettled with English colonists according to the plantation system of the Elizabethan government and the distinction between English and Irish deepened. ${ }^{9}$

The Tudor plantation policy aimed at a methodical supplanting of native power and authority in order to gain control over the island. Land became the commodity of power, particularly in the Ulster and Munster regions. Vast tracts of land were confiscated in the wake of the rebellions and the British crown turned it over to settlers, known as planters, from both England and Scotland. This process began during the reign of Henry VIII and continued under Mary I and Elizabeth I. It was accelerated under James I, Charles I and Oliver Cromwell. During Henry VIII's reign, the plantations were often small farms granted to individuals and clustered together. Under Elizabeth I, however, the policy shifted to the mass confiscations of land from Irish landowners. Subsequently, the number of foreign settlers from England, Scotland and Wales also increased dramatically. This created a shift in the demographics of both Ulster and Munster as the native Catholic Gaelic population was supplanted by large non-Irish communities with a Protestant identity. These communities replaced the older Catholic elite who shared a common Irish identity through religion, language, and culture. ${ }^{10}$

This also heightened the identity distinctions between the Irish natives and the English. Like the 1300s, there was a growing fear of fraternization between the Irish and the English. A 1675 publication titled The Moderate Cavalier; or the Soldiers Description of Ireland, A Book fitt for all Protestants Houses in Ireland discussed the difficult situation Cromwell's army faced as they ensconced themselves on Irish soil. The

\footnotetext{
${ }^{9}$ For further analysis of the role of identity in the Elizabethan period see: Kathleen Noonan, “'The Cruell Pressure of an Enraged, Barbarous People': Irish and English Identity in Seventeenth Century Policy and Propaganda”, The Historical Journal, Volume 41, No. 1 (March 1998), 151-177.

${ }^{10}$ Steven G. Ellis, Tudor Ireland: crown, community, and the conflict of cultures, 1470-1603 (London: Longman, 1985), 342-343.
} 
Lord Deputy and Commander-in-Chief of the English military was horrified to realize his soldiers were not only meeting with, but marrying local Irish women. In 1652 he considered a law that "any officers or soldiers marrying Irish women should lose their commands, forfeit their arrears, and be made incapable to inherit lands in Ireland." ${ }^{11}$ The law, according this work, was never enacted because it was far easier to round up local women and imprison them to "never let the English officers and soldiers come in contact with Irishwomen.” Protestant ministers started putting the fear of God in the troops and many soldiers, who according to the book, "would sooner burne... rather than marrie an Irish wife." ${ }^{\prime 2}$ Mixing bloodlines became a sin in the eyes of the military leadership and their Protestant God. This sin was reinforced when intermarriage was officially outlawed in the Penal Laws drawing a sharp distinction between the English and Irish in the 1600s.

Once these rebellions were finally quelled, the English authorities in the Pale established real control over Ireland for the first time, bringing a centralized government to the entire island. This government also successfully disarmed the native lordships, but it failed to completely eliminate rebellion. ${ }^{13}$ Parliament was called fifteen times to assist with administrative concerns between 1494 and 1641 as the Crown extended its authority throughout this period. ${ }^{14}$ The English were not successful in converting the Catholic Irish to the Protestant religion, however, and the brutal methods used by crown authority (including resorting to martial law) to bring the country under English control heightened resentment of English rule. Historian Daniel Eppley argues that during the Tudor and

\footnotetext{
${ }^{11}$ The Moderate Cavalier; or the Soldiers Description of Ireland, A Book fitt for all Protestants Houses in Ireland, (Cork, 1675), 41-45.

${ }^{12}$ Ibid, 41-45.

${ }^{13}$ For further analysis of this failure see: Hiram Morgan, "Never Any Realm Worse Governed: Queen Elizabeth and Ireland," Transactions of the Royal Historical Society, Sixth Series, Volume 14 (2004), 295308.

${ }^{14}$ R. F. Foster, Modern Ireland (1600-1972) (New York: Penguin Books, 1989), 50.
} 
Stuart periods, the English began developing a theory to squash a very problematic facet of the Protestant Reformation, that of civil disobedience, and this theory allowed for the justification of brutality against the Irish as Catholics as well. Protestantism called for obedience to civil authority while at the same time encouraging civil disobedience when leaders pursued polices contrary to the will of God. The monarchy of England established its authority as the final word on God's will, therefore eliminating any legitimate claim for rebellion against the Crown on religious grounds. ${ }^{15}$ Rebellions in Ireland were considered entirely treasonous because not only was the monarchy the ultimate interpreter of God's will, but the Catholics had no religious standing to interpret God at all. Any method to subdue the island was therefore justified under the banner of the will of God.

From the mid-sixteenth century and into the early seventeenth century, various crown governments continued to carry out the policy of land confiscation and colonization under the plantation policy established by Elizabeth. Scottish and English Protestants were sent as colonists to the provinces of Munster, Ulster and the counties of Laois and Offaly. These Protestant settlers replaced the Irish Catholic landowners who were removed from their lands. These settlers would form the ruling class of future British administrations in Ireland. As the Protestant settlers increased across the island, a series of Penal Laws, known as Na Péindlíthe in Gaelic, removed the Catholic majority from power by only recognizing the English Anglican Church as a source of authority. ${ }^{16}$

\footnotetext{
${ }^{15}$ Daniel Eppley, Defending Royal Supremacy and Discerning God's Will in Tudor England (England: Ashgate Publishing Limited, 2007), 223.

${ }^{16}$ T.A. Jackson, Ireland Her Own: An Outline History of the Irish Struggle for National Freedom and Independence (England: Cobbett Press, 1946), 67.
} 
Like the Statutes of Kilkenny in the 1300s, these laws were designed to isolate the native population from the power structure of Ireland.

\section{Violence and War in the 1600s}

The 1600s saw tension between the English and the Irish escalate into what many historians consider the bloodiest period in Anglo-Irish relations. Two periods of war (1641-1653 and 1689-1691) caused huge losses of life and resulted in the final dispossession of the Irish Catholic landowning class and their subordination as the Penal Laws were enforced once more. The first conflict resulted in eleven years of warfare, beginning with the Rebellion of 1641, when Irish Catholics rebelled against the domination of English and Protestant settlers established under the plantation policy. During the English Civil War, from 1642 through 1649, the Catholic gentry briefly ruled the country as Confederate Ireland. Oliver Cromwell, however, re-conquered Ireland from 1649 through 1653 on behalf of the English Commonwealth. Cromwell's conquest was the most brutal phase of the war. By its close, up to a third of Ireland's pre-war population was dead or in exile. As revenge for the rebellion of 1641, almost all remaining lands owned by Catholic Gaelic lords were confiscated and given to British settlers. Several hundred remaining native landowners were transplanted to Connacht, a region whose land was considered the poorest in the country for farming. This reduced the native population to near poverty level as tenant farmers on the land they once owned.

\section{Further Rebellion for the Restoration of a Catholic King}

Forty years later, Irish Catholics fought for James from 1688 to 1691, but failed to restore him to the throne of Ireland, England and Scotland. Ireland became the main battleground after the Glorious Revolution of 1688, when the Catholic James II left 
London and the English Parliament replaced him with William of Orange. The wealthier Irish Catholics backed James to try to reverse the Penal Laws and land confiscations, whereas Protestants supported William to preserve their property in the country. James and William fought for the Kingdom of Ireland in the Williamite War, most famously at the Battle of the Boyne in 1690, where James’ outnumbered forces were finally defeated. Jacobite resistance in Ireland was finally ended after the Battle of Aughrim in July 1691. The Penal Laws, which had been relaxed somewhat after the English Restoration, were re-enacted more thoroughly after this war, as the Protestant élite wanted to ensure that the Irish Catholics would not be in a position to repeat their rebellions of prior decades. ${ }^{17}$ Subsequent Irish antagonism towards England was aggravated by the economic situation of Ireland in the eighteenth century. Many absentee landlords managed their estates inefficiently, and food tended to be produced for export rather than for domestic consumption. The absentee landlord had become a common business framework across Ireland. Wealthy English families had vast landholdings in Ireland, particularly in the southern regions where the Irish had not been displaced by the planters. They let the daily management of the estate to hired help. They rarely visited their Irish estates and had little input into the conditions and concerns of their tenants. Two very cold winters towards the end of the Little Ice Age led directly to a famine between 1740 and 1741, which killed about 400,000 people and provoked over 150,000 of the Irish to emigrate. In addition, Irish exports were reduced by the Navigation Acts from the 1660s, which placed tariffs on Irish products entering England, but exempted English goods from tariffs on entering Ireland. In spite of the economic difficulties across the island, most of

\footnotetext{
${ }^{17}$ For a thorough analysis of the new historiography of the Tudor and Stuart period see the essay collection Age of Atrocity: Violence and Political Conflict in Early Modern Ireland, eds. David Edwards, Pádraig Lenihan, and Clodagh Tait, (Dublin: Four Courts Press, 2007).
} 
the 1700s were relatively peaceful in comparison with the preceding two hundred years, and the population doubled to over four million. The Irish Parliament also began meeting biennially as it assumed greater power in the collection of revenue as foreign wars demanded funds. As the role of the Parliament increased, so too did the political activity of the Anglo-Irish ruling class and they began pressuring the Crown for equal status with the English nobility.

\section{The Tides Turn in the $1700 \mathrm{~s}$}

By the late eighteenth century, many of this Anglo-Irish ruling class had come to see Ireland as their native country, but a distinction remained between them and the native population. These landowners were not the absentee landlords, but those that chose to make Ireland their permanent home. A Parliamentary faction led by Henry Grattan agitated for a more favorable trading relationship with England and for greater legislative independence for the Parliament of Ireland. However, reform in Ireland stalled over the more radical proposals to enfranchise Irish Catholics, the bulk of the population of the country. In 1782, the Irish Parliament was declared a sovereign assembly, independent of the political structure of Westminster. Once this was accomplished, Catholics were able to push through limited reforms and they managed to achieve limited enfranchisement with the Catholic Relief Act of 1792. It came, however, with a significant caveat as Catholic Irishmen were not allowed to serve in the newly independent Irish Parliament.

This period also saw a dramatic change in the role of the Lord-Lieutenant, or Viceroy, for Ireland. This position was critical in Ireland because of the relationship between the Lord-Lieutenant and the Irish Parliament. While the governing body was comprised of elected Protestants from Ireland, the true head of the country was the Lord- 
Lieutenant, appointed by the English government and answerable to that same government. Prior to 1767, the Lord-Lieutenants traditionally did not reside in Ireland and their influence was therefore limited. Once the Lord-Lieutenant took permanent residence in the country, he was able to establish greater control over the daily governing of the country. As he was an official appointed by the Crown, his loyalty was to England. After 1767, Ireland became tied more closely politically with England than in previous periods although its precise constitutional status was ambiguous. ${ }^{18}$

Between 1782 and 1800, the Irish government ruled the country theoretically with little ties to England other than loyalty to the crown. In reality, however, legislation often mirrored that generated from Westminster, and the Anglo-Irish Ascendency governed more from self-interest and with the ever-present influence of the Lord-Lieutenant as opposed to the needs of the larger population. It was modeled on the English Parliament and both houses consisted of the landed gentry, most of whom had supplanted the native population in various wars and civil conflicts over the centuries. The popularly elected constituency was more often than not, quite small and insignificant and although the Anglo-Irish were only ten percent of the population, they held every seat in Parliament. ${ }^{19}$ The legislature then filled the civil administration of Ireland with fellow Anglo-Irish, and by the end of the decade, a massive gulf had developed between the government and the native population.

Although they had made inroads into the politics of their own country, the native Catholics continued to suffer under the oppressive Penal Laws. These laws placed

\footnotetext{
${ }^{18}$ Ireland was referred to as a distinct kingdom, a subordinate kingdom, and a colonial holding throughout the 1700 s and 1800 s.

${ }^{19}$ Douglas Kanter, The Making of British Unionism, 1740-1848: Politics, Government and the Anglo-Irish Constitutional Relationship (Dublin: Four Courts Press, 2009), 201.
} 
significant restrictions on specific religious groups. The most significant of the Penal Laws disenfranchised Catholics from political life in England and Ireland. Catholics and Presbyterians were barred from holding public office. There was a ban on intermarriage between Catholics and Protestants. Presbyterian marriages were not legally recognized by the state. Catholics were banned from owning firearms or serving in the military. Catholics could not serve in Parliament. They were barred from the legal professions and the judiciary. On a death by a Catholic, his legatee could benefit by conversion to the Church of Ireland. Catholics could not buy land under a lease of more than thirty-one years. There were other lesser restrictions as well and dissenters also faced persecution on a lesser scale. In 1791 a group of Protestants, largely compromised of Presbyterians, held the first meeting of what would become the Society of the United Irishmen. Originally they sought to reform the Irish Parliament again as it was dominated by those belonging to the state church, the Protestant Church of Ireland. They also sought Catholic Emancipation in order to strengthen their cause and they fought to remove religion from politics. When their ideals seemed unattainable they became more determined to use force to overthrow British rule and establish a non-sectarian republic. Their activity culminated in the Irish Rebellion of 1798 as anger continued to swell against the tithes paid to the Church of England as the official faith of the country. Mail coaches were intercepted and burned, insurrections broke out in several counties, including Dublin, Kildare, Meath and Leinster. It was suppressed through the use of bloody and violent means. In Ulster, the Battle of Ballynahinch on the $12^{\text {th }}$ of June brought the North under control and by the $22^{\text {nd }}$ of that month, the town of Wexford was retaken by English forces. In August, the French landed in Killala Bay and marched into the heart of 
Connaught in support of the Irish rebels, but resistance was short-lived and by early September the island was back under English military control. William Pitt, in response to the uprising, stressed the need for "immediate steps for a union" in order to quell the crisis. $^{20}$

\section{The Act of Union and the Question of the Catholic in England}

In 1800, following the Irish Rebellion of 1798, both the British and the Irish parliaments simultaneously enacted the Act of Union. French involvement was particularly troublesome as England battled her longtime enemy in a series of Revolutionary Wars and the threat of a French invasion linked to a large-scale Irish rebellion seemed very possible. The merger created a new political entity called the United Kingdom of Great Britain and Ireland. The justification for the union centered on the security, both financially and militarily, that the combination would bring to both nations. Lord Kames argued that there was a pressing need for a "united defence against the powerful” and “other tribes are swallowed up by conquest” so Ireland was no different in the face of national security. ${ }^{21}$ It also brought an end to the confusing status surrounding Ireland. For decades questions concerning Ireland’s status vexed both nations. Was it a colony? A province? Part of a dual kingdom? With the Act of Union, Ireland was no longer a peripheral subject within a larger colonial empire. It had become a central issue in the domestic political sphere of England, thus the English now had to confront the turmoil and chaos directly. The union had essentially forced the wealthy Protestant elite and the rural largely poor Catholic majority together as a united group of

\footnotetext{
${ }^{20}$ Letter from William Pitt, The Later Correspondence of George III: Volume I, ed. Arthur Aspinall (Cambridge: Cambridge University Press, 1962), 68; For secondary analysis of this turbulent period of revolutionary uprisings see: Alan Booth, "Irish Exiles, Revolution and Writing in England in the 1790s," in Irish Writing: Exile and Subversion, ed. Paul Hylands and Neil Sammells (London: Macmillan, 1991).

${ }^{21}$ Lord Kames, Sketches of the History of Man, Volume Two (Edinburgh, 1788), 260.
} 
people for the first time ever. It also theoretically united the Irish other with the English under the banner of Great Britain. The legislation of Ireland was, however, messy and incoherent. England faced an uphill battle in its attempt to reconstruct Ireland in its own image.

The initial description of the union between England and Ireland was that of a marriage. England was the groom and Ireland the bride as the Irish were absorbed into the domestic political sphere of the United Kingdom. What this implied, however, was the idea of a contract between the two nations and both the Protestants and the Catholics made assumptions about that contract. When the Irish Parliament was abolished, the Protestant landed gentry had to be appeased in exchange for support on the measure. Countless political favors were given away, including fifteen promotions into the peerage. Seventy-four MPs were given government positions, eleven lawyers and ten ecclesiastics were appointed to positions of authority, sixteen annuities were granted, seats in the English Parliament were purchased and over a million pounds was paid out in borough compensation for political losses. ${ }^{22}$ There was no doubt that the English Parliament bent the law almost to the breaking point in order to achieve its ends and absorb Ireland into the United Kingdom. ${ }^{23}$

The debates concerning the Act of Union raged on for years after its inception, particularly as the issue of Catholic emancipation immediately arose. Catholics assumed that this marriage contract would guarantee them greater freedom and rights and their assumptions were not off base. Part of the agreement drafted by Pitt the Younger forming

\footnotetext{
${ }^{22}$ Kevin Whelan, "The other within: Ireland, Britain and the Act of Union," in Acts of Union: The Causes, Contexts and Consequences of the Act of Union, eds. Dáire Keogh and Kevin Whelan, (Dublin: Four Courts Press, 2001), 17.

${ }^{23}$ D. Wilkinson, “How did they pass the union? Secret Service expenditures in Ireland 1799-1804,” History 82 (1997), 251.
} 
the basis of union was that the Test Act would be repealed in order to remove any remaining discrimination against Roman Catholics, Presbyterians, and other dissenter religions in the new nation within the United Kingdom. King George III however, invoked the provisions of the Act of Settlement 1701 and fervently blocked attempts by Prime Minister William Pitt the Younger toward emancipation. Making his opinion quite clear, the king adamantly stated that "any man who proposed further concessions to Catholics” was a "personal enemy." ${ }^{24}$ A number of key members of Parliament, including Pitt, resigned under the growing xenophobia and anti-popery sentiment. The emancipation measure was brought before Parliament in both 1801 and 1807 and under vote from an entirely Protestant assembly, it failed both times.

English statesmen and politicians continued their justifications of the Union after the failure to grant Catholic emancipation under the guise of economic prosperity for both nations. In 1812, economist Edward Wakefield argued that while Great Britain did not produce corn "sufficient to supply her inhabitants" Ireland had a surplus and the Act of Union, with its free trade zone, created a mutually beneficial situation. ${ }^{25}$ He believed that the Act of Union was adopted after a "mature and most attentive consideration of all its bearings and probably effects" and the Irish simply had to stop ascribing "every evil under which that country is now suffering” solely to Great Britain. ${ }^{26}$

\footnotetext{
${ }^{24}$ King George III, quoted in Thomas Bartlett, The Fall and Rise of the Irish Nation: The Catholic Question 1690-1830 (London: Dill and MacMillan, 1992), 264. After the Glorious Revolution, England established a series of provisions to prevent a Catholic monarch from ever taking the throne. The Act of Succession clearly defined the line of succession to the throne of England and among the provisions, it was stated that a Catholic was forever forbidden to take the throne of the kingdom. It was this provision that George III invoked to argue for the continued repression of civil rights against Catholics across the growing empire.

${ }^{25}$ Edward Wakefield, An Account of Ireland, Statistical and Political: Volume I, (London: Longman, Hurst, Reese, Orme, and Brown, 1812), iii-iv.

${ }^{26}$ Ibid, vi.
} 


\section{The Fight for Emancipation}

As the years passed, the Act of Union became more and more unpopular in Ireland, and political factions continued to rally around its repeal. Emancipation was, however, the more pressing issue for two reasons. First it provided the most immediate access to the political process. Second, it had a far greater chance of success than repeal of the Act of Union. In 1823, an enterprising Catholic lawyer, Daniel O’Connell, known in Ireland as The Liberator, began an ultimately successful campaign to achieve emancipation, and to be seated in the English Parliament. The Catholic Association was also formed that year to promote political activism on a broad scale. As O’Connell stood firmly against the Act of Union, the CA fought for its repeal, but the organization initially centered largely on the more pressing issue of emancipation. This campaign, backed by the heavy fundraising and support of the Catholic Association, culminated in O'Connell's successful election in the Clare by-election, which revived the parliamentary efforts at reform. The Catholic Relief Act of 1829 was eventually approved by the English Parliament under the leadership of Prime Minister Arthur Wellesley, first Duke of Wellington. This indefatigable Anglo-Irish statesman, a former Chief Secretary for Ireland, and hero of the Napoleonic Wars successfully guided the legislation through both houses of parliament. Wellesley then persuaded King George IV to concede to signing the bill into law in 1829 under threat of resignation. The continuing obligation of Roman Catholics to fund the established Church of Ireland, however, led to the sporadic skirmishes of the Tithe War from 1831 through 1838 and pressure continued to mount for repeal of the Act of Union. ${ }^{27}$ It was this turbulent, often bloody relationship over the

\footnotetext{
${ }^{27}$ Robert Kee, The Green Flag (London: Weidenfeld and Nicholson, 1972), 187-243.
} 
centuries that set the stage for the culture clash of the 1800s as the Irish migrated in record numbers.

\section{A Clash of Cultures and its Significance}

The history of Anglo-Irish relations up to the 1800s is rife with tension, conflict, and bloodshed. While English claims in, and over Ireland, might have been said to have begun with the invasion by Henry II in 1171, the pursuit of conquest was limited and erratic. Celtic Ireland remained almost untouched, while the English monarchy had neither the power nor inclination to rigorously pursue any policy which might conquer, pacify or govern all of Ireland, even as late as the 1700s. However, from the beginning of the relationship, its keynote was firmly established as that of English expansionist aggression meeting with consistent resistance in Ireland.

The question of why this aggression took place, and why it was resisted, resides somewhat in the historical framework of the centuries in which it occurred. There was nothing unique or abnormal about such conflicts in the Europe of the time. However, another important aspect of the answer does have enduring significance - that which emphasizes a clash of cultures. It was this clash that began in the 1100 s and continued well through the nineteenth century and helped to create the negative Irish other in English society during the Victorian Era.

\section{From Ethnicity to Nation as England and Ireland Collide}

Scholarship on the early medieval period reflects the fluctuating evolution of ethnicity, national identity, and the concept of a nation. By the early modern period however, these distinctions were becoming more solidified as English involvement in Ireland became more direct. When Richard de Clare, second Earl of Pembroke, 
nicknamed Strongbow, arrived on Irish shores in 1169, his conquest marked the beginning of an English presence on the island. The English crown did not, however, begin asserting full control of the island until after the English Reformation, when questions over the loyalty of Irish vassals provided the initial impetus for a series of military campaigns between 1534 and 1691. Catholic Ireland was a powerful reminder of the religious strife that had torn England apart and there was genuine fear of Catholic support against the Protestant crown.

In order to quell such rebellions, the policy of plantation was implemented in addition to the various strong-armed military campaigns. Catholic lands were seized and given over to those loyal to the Crown, which led to the arrival of thousands of English and Scottish Protestant settlers. Religion thus became a great divide between the native population and the ever-increasing foreign contingency residing on Irish soil.

Tensions continued to rise across Ireland as these two divergent groups struggled for dominance over both the actual land and political power. Like Evans and Jones, Nicholas Canny investigated the nature of this tension in relation to Tudor colonization in Ireland. Coming with pre-conceived ideas of a barbaric society dating back to the 1100 s, English adventurers tailored the Irish to fit these ideas, despite contradictory evidence. Thus, in order to justify their conduct, they set about convincing themselves - and England - that the Irish were pagans, and thus uncivilized. The practice of transhumance was inflated into proof that the Irish were nomads, and hence barbarians. So it was justifiable for a superior people to subdue them, with the declared purpose of civilizing 
them: if they resisted (as they did) this proved their intransigent barbarism and justified their extermination. ${ }^{28}$

Canny links this image of the Irish with the English self-image: the adventurers and colonists were unsure of themselves, anxious to retain a view of their own behavior as that of civilized Christians. Moral justification for the claim to superiority, and the conquest of Irish land, was sustained by imputing inferiority to the native inhabitants. They deliberately did not seek to understand the Irish, and remained obstinately blind to such characteristics as contradicted their convenient image, for that image was necessary for their own self-regard, and for the respectable continuance of their dominance.

Richard Hoffman also argued that the English perceptions of the Irish as the other were rooted deeply in the past. At the Council of Constance, in the early fifteenth century, English representatives argued their claim to equal national status on the grounds that their culture and land were distinct from others. Hoffman posited that for those representatives at Constance, their national status was related to culture and geographic space dating back centuries. ${ }^{29}$ Therefore, when the Anglo-Normans arrived in Ireland in the 1100s, they already understood the inhabitants of Ireland as other on the basis of a racial or ethnic identity and this distinction was merely solidified over the centuries and not created in the Tudor period.

\section{Centuries of Conflict and the 1800s Crises}

It is vital to understand the medieval and Tudor concepts of identity and the distinction the English had already made between themselves and Ireland in order to

\footnotetext{
${ }^{28}$ Nicholas Canny, Making Ireland British, 1580-1650 (Oxford: Oxford University Press, 2003).

${ }^{29}$ Richard Hoffman, "Outsiders by Birth and Blood: Racist Ideologies and Realities around the Periphery of Medieval European Culture,” in Studies in Medieval and Renaissance History, IV, eds. J.A.S. Evans and R.W. Unger (Canada: University of British Columbia, 1983), 3.
} 
understand the significance of the socio-political milieu of the 1800s. There has been a great deal of research on the later decades of the 1800s, but the entire century is one of tension and conflict between these two nations. Such deep-seeded feelings on both sides did not simply spring into being over a few laws and a handful of immigrants. The historiography clearly indicates a long-standing evolution of national identity and the consequences of that evolution between the English and the Irish. This work focuses on the analysis of the changing perception of those differences, with the Irish as the other, that evolved throughout the nineteenth century as contact shifted from Irish soil to English soil.

Much of the historiography of the early decades of the nineteenth century focuses on the early agitation against the Act of the Union, Catholic Irish nationalism and the figures associated with those movements. Works such as Angus Macintyre's detailed analysis of Daniel O’Connell’s powerful influence through the Irish Party serves as a model for this emphasis. His work is an excellent analysis of the role of the Irish Party, and its larger than life leader, but it does not stray from its political bent. ${ }^{30}$ Kevin Nolan's work, released the same year, offers a more broad political perspective in its analysis of the complex relationship between England and Ireland, but it too does not stray from Parliament, parties, and policy. ${ }^{31}$ Other historians have looked at the Young Ireland movement, such as Richard Davis’ work The Young Ireland Movement. Although he examined a different aspect of the Irish nationalist movement, Davis’ arguments still

\footnotetext{
${ }^{30}$ Angus MacIntyre, The Liberator: Daniel O'Connell and the Irish Party, 1830-1847 (London: H. Hamilton, 1965).

${ }^{31}$ Kevin Nolan, The Politics of Repeal: A Study in the Relations between Great Britain and Ireland, 18411850 (London: Routledge, 1965). For further work in the same vein see Lawrence J. McCaffrey, Daniel O'Connell and the Repeal Year (Kentucky: University of Kentucky Press, 1966); Oliver MacDonagh, The Hereditary Bondsman: Daniel O’Connell, 1775-1829 (New York: Weidenfeld and Nicolson, 1987).
} 
focused on the political force of this growing movement and its influence in shaping socio-political thought during the period. ${ }^{32}$ Robert Sloan's more recent work, William Smith O'Brien and the Young Ireland Rebellion of 1848, uses Macintyre's work as a framework by examining the leadership of the movement and O'Brien's role in shaping the political landscape of the era. ${ }^{33}$ Douglas Kanter took a different approach in his examination of the role of the British elite in shaping policy during the late 1700s and early 1800s through their influence and power in the creation and passage of the Act of Union. But he too keeps his analysis confined to the political arenas of the time. ${ }^{34}$ The historiography of this period has little analysis from social historians as the political turmoil took center stage and sources are problematic due to a lack of proper records. There is a dearth of discussion on the influx of immigrants into England in the pre-Famine years. There is also little on the social climate of Ireland that drove people from its shores. What were English perceptions of the Irish prior to the famine? While historians have thoroughly documented the public opinions of the late nineteenth century, there has been little work on the early period. Were relations as difficult in the early years as they were in the later decades of the 1800s? If not, what changed? How did the English view their neighbors across the sea and what did they think of them as they entered England? As the crisis of famine crept closer, how did opinions shift as Parliament debated the Irish Poor Laws that would increase English tax burdens? Most importantly, how did these opinions begin to evolve into the later hatred of the nineteenth century? These critical questions have often been overlooked in the overwhelming volume of

\footnotetext{
${ }^{32}$ Richard P. Davis, The Young Ireland Movement (Dublin: Gill and Macmillan, 1988).

${ }^{33}$ Robert Sloan, William Smith O'Brien and the Young Ireland Rebellion of 1848 (Dublin: Four Courts Press, 2000).

${ }^{34}$ Douglas Kanter, The Making of British Unionism, 1740-1848: Politics, Government and the Anglo-Irish Constitutional Relationship (Dublin: Four Courts Press, 2009).
} 
works on the leaders, politics, and nationalism of the early nineteenth century. It is vital to examine these questions in order to create a comprehensive picture of the relationship between England and Ireland as the Empire reached its height.

\section{The Early Years of the Coming Crisis}

By the 1800s, the connection between England and Ireland extended back centuries and as the Industrial Revolution created work opportunities, the poor of Ireland, now a part of Great Britain through the Act of Union but completely culturally distinct from England, began to cross the Irish Sea. According to Jeffrey G. Williamson, professor of Economics at Harvard University, Irish immigration into England did not really become important until after the French Wars. The 1820s are often viewed as the benchmark decade in the decades prior to the famine because of the mini-famines during those years. ${ }^{35}$ Unfortunately, there are no reliable estimates of the total number of immigrants during the years between the Battle of Waterloo and the Famine. The Emigration Commissioner's figures for the 1820s and 1830s are nothing more than informed guesses, and the English census enumerators did not ask for a birthplace until $1841 .{ }^{36}$ In the 1836 Report on the State of the Irish Poor in Great Britain, Poor Law commissioner Cornewall Lewis argued that the Irish migrations of the 1820s and 1830s were "nearly unparallelled in the history of the world," yet he did not give any actual figures to support that claim and the media stressed that the 1830s was the first decade in which immigration had been considered in Great Britain as a “national measure.”37

\footnotetext{
${ }^{35}$ Jeffrey Williamson, "The Impact of the Irish on British Labor Markets During the Industrial Revolution," The Journal of Economic History, Vol. 46, No. 3, (September, 1986): 693.

${ }^{36}$ Ibid, 701.

${ }^{37}$ Cornewall Lewis, "Report on the State of the Irish Poor In Great Britain," Parliamentary Papers, 1836 Vol. 34: 429; "The Poorer Classes in Ireland," The Monthly Review From May to August Inclusive, Volume II (London: G. Henderson, 1836): 119.
} 
Emigration Committee commissioner Francis Scully reported that a "considerable number emigrated” from the Barony of Middlethird in County Tipperary in 1834, but like Lewis, he could not provide exact figures. ${ }^{38}$ Commissioner Duckett estimated that “upwards of 300 persons” emigrated from various towns in County Waterford from 1830 to 1835, and "perhaps 100 or 200 in each year" from the Barony of Decies in the same county, but he too could not confirm these figures. ${ }^{39}$ Estimates on immigration were combined with reports on urban expansion and military reports to reflect a growing foreign population as well. In 1829, for example, London added 45,000 new houses and 750 new streets and squares, thus confirming reports that the population was increasing at a rapid rate. That increase, like vague statistics in Parliament, could not specifically be attributed to immigration. ${ }^{40}$ By 1830, 42.2 percent of the British Army listed Ireland as their birthplace with the largest proportion recorded in the infantry units. ${ }^{41}$ The Manchester Guardian reported on the St. Patrick's Day march of the $87^{\text {th }}$ Regiment, the Irish Fusiliers from their barracks in Salford to mass at St. Augustine’s Catholic Church. Many of the regiment wore the shamrock and the band played Irish music as they marched. ${ }^{42}$ This example serves to illustrate the strong Irish presence in the northern towns well before famine immigration began in earnest. Historians have struggled to provide accurate estimates for the pre-famine years in an attempt to assess claims like Lewis'. Culling information from a wide variety of sources, Irish immigration into England from 1787 through 1821 was likely 6.7 percent of the total population of the

\footnotetext{
${ }^{38}$ Commissioner Francis Scully quoted in "The Poorer Classes in Ireland,” The Monthly Review From May to August Inclusive, Volume II (London: G. Henderson, 1836): 123.

${ }^{39}$ Commissioner Duckett, Ibid, 124.

${ }^{40}$ The Economist, Issue 23 January 27, 1844), 430.

${ }^{41}$ Harold Hanham, "Religion and Nationality in the Mid-Victorian Army," in War and Society, ed. Michael R.D. Foot (New York: Barnes and Nobles Books, 1973), 162.

${ }^{42}$ Manchester Guardian, March 20, 1830.
} 
island. With a population averaging from six to eight million, these estimates confirm anecdotal reports of extensive Irish immigration prior to the Great Famine. ${ }^{43}$

Part of this immigration pattern in the early decades of the 1800s came from the English response to continued famines and economic hardships across Ireland. Enacting Poor Laws in Ireland provided one possible solution, and debates in Parliament throughout 1836 provided another. In a report released by the Emigration Committee, a significant number of commissioners on the panel recommended an extensive voluntary emigration from Ireland in order to relieve the economic burdens of the native population. With the population increase throughout the 1700s, parts of Ireland were becoming extremely overcrowded. By 1790 the island's population was an estimated four million people. In the fertile farm regions, the population density has reached a crisis stage. A typical farm in County Clare, for example, with one tenant in the mid-1700s maintained between ninety and one hundred tenants by the mid-1800s. ${ }^{44}$ Many of those present pointed out that as of the mid-1830s, there had been very little emigration from certain regions across the country, including the Baronies of Inveragh and Trughenackmy in County Kerry and the Baronies Conello and Coshlea in County Limerick. In many of the areas, there were considerably high numbers of smaller farmers evicted for not paying rent, thus creating a serious surplus of labor. Commissioner Daly argued that in order to "effect the price of labour" in any significant way and to alleviate the surplus, at least

43 G. O’Brien, An Economic History of Ireland from the Union to the Famine (London, 1921), 207-221; Williamson, "The Impact of the Irish on British Labor Markets,: 706; For an secondary analysis of this immigration see: E.H. Hunt, Regional Wage Variations in Britain, 1850-1973 (Oxford: Oxford University Press, 1973).

${ }^{44}$ W. H. A. Williams, 'Twas only an Irishman's dream: the image of Ireland and the Irish in American popular song lyrics, 1800-1920 (Illinois: University of Illinois Press, 1996), 16. 
“one-half of the labourers” needed to leave the country. ${ }^{45}$ Commissioner Butler added that the current rate of immigration from Ireland had not been "sufficient to raise wages or lower rents" because it had not been substantial enough to reduce the "competition for employment or small holdings.” ${ }^{46}$ Sir Robert Peel argued that removing a mere one-third of the population would suffice, but he too believed immigration was necessary for the future of the nation. ${ }^{47}$ The Emigration Committee, in perhaps a bit of naïveté, focused their attention on the United States. They stressed the availability of land there and the “certain prospect of independence” instead of "inhabiting the same miserable hovel” and

likely dying of disease or starvation. ${ }^{48}$ What they failed to recognize in this proposal was the contrast between travel to England and travel to America. Why venture thousands of miles when the prospects of a better life lay directly across the Irish Sea for far less money and danger?

\section{The Early Irish Impact in England}

The question that challenges historians about this immigration pattern rests in its impact. The English working class believed the Irish had a significant impact on employment and working conditions. Those attitudes, adopted by the middle class, would play a significant role in the later prejudices and hatred in the post-famine decades. How valid was that impression during the early decades of the nineteenth century? It is vital to answer this question in order to understand how English perceptions, whether based in fact or not, defined the Irish identity in the wake of Chartism, the Famine, and the later waves of immigration .

\footnotetext{
45 “The Poorer Classes in Ireland,” The Monthly Review From May To August Inclusive, (London: G. Henderson, 1836): 119-128.

${ }^{46}$ Ibid, 121.

${ }^{47}$ Ibid, 121-122.

${ }^{48}$ Ibid, 120.
} 
The early historiography on the English Industrial Revolution believed the Irish mattered. Arthur Redford, for example, thought "the main social significance of the Irish influx lay with its tendency to lower the wages and standard of living of the English wage-earning classes.” ${ }^{49}$ And while Redford thought this tendency was obvious during the Famine of the late 1840s, he believed "the disastrous social effect of the Irish influx was, however, already apparent in the $1830 \mathrm{~s} .{ }^{50}$ Much of this research stemmed from the contemporary perspectives reflected in various Parliamentary Reports from observers with strong opinions on the Irish and economic theories. The Select Committee on Disturbances in Ireland as well as in the 1827 Select Committee on Emigration both reflected a growing fear of a glut of unskilled Irish workers. Witnesses included cotton manufacturers from Lancashire, industrialists, and the economic theorist Thomas Malthus. ${ }^{51}$ Modern historians often concur with these voices from the Victorian Era. In the 1970s, economist Sidney Pollard announced that there was an "unanimity about the historical facts” in regard to the relationship between the Irish worker and deteriorating working conditions in the industrial centers based on the work of the early historians in this area. $^{52}$

Clearly the perception of the Irish as a significant problem cannot be denied. Was this in fact the reality? In the early 1800s, the first stage of the Industrial Revolution in England, unskilled labor's real wage gains lagged far behind the profit margins during the

\footnotetext{
${ }^{49}$ Arthur Redford, Labour Migration in England, 1800-1850 (Manchester: W.H. Chaloner, 1926), 159.

${ }^{50}$ Ibid, 159.

${ }^{51}$ Their reports can be found in Great Britain, "Report on the State of the Irish Poor In Great Britain," Parliamentary Papers, Vol. 34 (1836): xxxiii and 59-66.

${ }^{52}$ Sidney Pollard, "Labour in Great Britain," in The Cambridge Economic History of Europe: Volume VII: The Industrial Economies: Capital, Labour, and Enterprise, eds. P. Mathias and M.M. Postan (Cambridge: Cambridge University Press, 1978), 103.
} 
economic growth in the business sector. ${ }^{53}$ This trend was not, however, due only to Irish immigration. Scholars have acknowledged the impact of new technology and the migration of rural English labor to urban areas as factors. ${ }^{54}$ While there were other issues affecting the working classes of England, however, the problematic influx of immigrants into the urban centers was not only a matter of perception. In the First Annual Report of the Poor Law Commission, James Phillips Kay Shuttlesworth projected what he referred to as the "crowding-out effects" of the Irish. Shuttlesworth pointed out that new Irish immigrants in the north will, as the years progressed, crowd out the potential native-born poor migrant from the south. ${ }^{55}$ His prediction proved correct as continued efforts by the Poor Law Commission for continued reform, led by Edwin Chadwick, failed to encourage southern paupers to travel to the northern factories for work. An analysis of English rural migration also supports Shuttlesworth’s hypothesis. Irish immigration continued to climb in the pre-famine years, reaching a peak in the 1840s. English rural migration to the urban centers reached its nadir during that same period, falling from 0.51 percent per year in the 1830 s to 0.21 percent per year in the 1840 s. $^{56}$

These immigrants were arriving in England with little to offer the skilled labor market and they began to heavily populate the urban centers. According to economist

\footnotetext{
${ }^{53}$ Peter H. Lindert and Jeffrey G. Williamson, “English Workers’ Living Standards During the Industrial Revolution: A New Look,” Economic History Review, 36 (February, 1983): 1-25.

${ }^{54}$ Williamson, “The Impact of the Irish on British Labor Markets," 694.

${ }^{55}$ James Phillips Kay Shuttlesworth, "First Annual Report of the Poor Law Commission,” Parliamentary Papers, Vol. 35 (1835): 188.

${ }^{56}$ Williamson, "The Impact of the Irish on British Labor Markets," 696; For a controversial look at this issue see Ruth-Ann Harris The Nearest Place that Wasn't Ireland: Early Nineteenth-Century Labor Migration (Iowa: Iowa State University Press, 1994). Her work takes Engels at face value and she argues that most of these early workers into England were temporary migrants and did not stay. Most historians of the period argue otherwise based on local record sources. For a broad analysis on the issue of population and migration see L. Kennedy and L.A. Clarkson, "Birth, death and exile: Irish population history, 17001921" in An Historical Geography of Ireland, eds. B.J. Graham and L.J. Proudfoot (London: Academic Press, 1993); K.H. Connell, The Population History of Ireland, 1750-1845 (Oxford: Oxford University Press, 1950).
} 
Adam Smith, as early as the 1780s, the Irish accounted for most of the porters, coalheavers, and prostitutes in London. ${ }^{57}$ The expert witnesses who testified before Parliament for the 1836 report on the poor of England viewed the Irish that way, and the 1851 census supported their claims with actual data. Furthermore, the Irish entering England were largely illiterate as well. ${ }^{58}$ These were the bottom rung of the immigrants leaving Ireland, perhaps because English shores were cheaper than the United States and therefore those with the least travelled the shortest distance to greener pastures. Liverpool was often the first stop. The heaviest concentration of immigrations in both the first wave of the 1820s and the second wave of the 1840s were found in the industrial giants of Liverpool and Manchester in the north.

Although the Irish rarely qualified for any official poor relief in Britain before 1834, they did receive unofficial welfare transfers, thus creating a real financial burden for the local population long before the new Poor Laws. While England's Poor Laws dated back centuries in a variety of different forms, after the Act of Union between Great Britain and Ireland, debates began on the implementation of similar laws in Ireland; laws that would only increase the tax burden on the English if the Irish proved too poor to pay for their own workhouses and relief systems. In 1834, just before the adoption of the new Poor Law Act, the commissioners determined that approximately 2.4 million people in Ireland fit the criteria for potential relief under the laws. ${ }^{59}$

\footnotetext{
${ }^{57}$ J. H. Clapham, "Irish Immigration into Great Britain in the Nineteenth Century," Bulletin of the International Committee of Historical Sciences, 20 Vol. 5 (July 1933): 596; E.P. Thompson, The Making of the English Working Class (New York: Vintage, 1963), 433-434.

${ }^{58}$ E.D. Steele, “The Irish Presence in the North of England, 1850-1914,” Northern History, 12 (1976): 224.

${ }^{59}$ Great Britain, Third Report of the Commissioners for Inquiring into the Condition of the Poorer Classes in Ireland, House of Commons, 43 (1836): xxx, 5.
} 
The immigration from Ireland in the pre-famine decades was driven by the same forces in place during the famine period, albeit much smaller in scope. There were poor harvests in 1800, 1801, 1816 through 1818, 1822, and 1831, while partial scarcities had been common for decades. During the 1822 crisis, there were reports that the poor of West Mayo were eating fishheads discarded by east coast fishermen and the carcasses of porpoises washed up on the beaches. ${ }^{60}$ In 1827, draper and schoolmaster Amhlaoimh Ó Súileabháin described how he and his middle-class friends doled out maize to the poor of Callan in County Kilkenny. Three years later, his diary entries described those same poor as near starvation once again. ${ }^{61}$ With the ever increasing population, these partial famines threatened to slip into a full-blown subsistence crisis. This, combined with the ever increasing evictions and farm closures, backward agricultural practices and outdated farming equipment, led to the mass failure of small farms and added to the growing woes of the nation. ${ }^{62}$

\section{Early Paternalism}

The debates and considerations surrounding the various relief measures for Ireland throughout the 1820 s and 1830s reflect a more complex perspective toward the Irish than just hatred however. While there were problems, as the testimonials and newspapers indicated, there was also a paternal, protective attitude toward the simple native peasant in the early decades of the nineteenth century. The concept of a marriage between the two countries had faded as Irish agitation against the Act of Union increased,

\footnotetext{
${ }^{60}$ Cormac Ó Gráda, Ireland Before and After the Famine: Explorations in Economic History, 1800-1925, Second Edition (England: Manchester University Press, 1993), 2; W.H. King, Account of the Fisheries in 1822 on the Western Coast of Ireland (Dublin, 1823), 4-5.

${ }^{61}$ Amhlaoimh Ó Súileabháin, The Diary of Humphrey O’Sullivan (Dublin: Irish Texts Society Simpkin, Marshall, 1936), 187, 337. His name translates from Gaelic as Humphrey O’Sullivan.

${ }^{62}$ Ó Gráda, 34, 82-89.
} 
but it was replaced by a fatherly attitude toward a simple child. Edward Wakefield said that England needed to throw the "broad parental shield of the British monarchy over the farthermost parts of Ireland” in order to protect her people from harm. ${ }^{63}$ The media argued that the Irish deserved better and they encouraged England to take a hand in Ireland's “ultimate success." 64

The natives, unsophisticated and primitive, were quaint folk with backward superstitions and a traditional, rural way of life. It was up to England as the greater nation to "lend the prudent hand" toward the impoverished Irish so they need not go abroad to “better their fortunes,” but remain instead in Ireland to improve their homeland. Books and stories, such as Philip Dixon Hardy’s Legends, Tales and Stories from Ireland, were published on the charming folk tales of these simple people. His 1837 work is a collection of short stories, both new and old, that reflect the peasant life throughout Ireland. "Paddy Doyle’s First Trip to Cork,” for example, is a tale of a rural farmer’s first experience in an urban center. He picks up stakes, takes his primitive wagon into the city and meets a host of people who amaze and confound him. Doyle is portrayed as confused, overwhelmed, and in awe of the wonders of this strange new world. He is, as are many of the characters in Hardy's collection, a simple country man with no knowledge or experience of the sophisticated world beyond his fields and farmland. ${ }^{65}$ Thomas Croften Croker's Fairy Legends and Traditions in the South of Ireland was another popular publication that presented the Irish as a child-like people seeped in quaint

\footnotetext{
${ }^{63}$ Edward Wakefield, An Account of Ireland, Statistical and Political: Volume I (London: Longman, Hurst, Reese, Orme, and Brown, 1812), vi.

64 “The Poorer Classes in Ireland,” The Monthly Review From May to August Exclusive, (London: G. Henderson, 1836): 125.

${ }^{65}$ Philip Dixon Hardy, "Paddy Doyle’s First Trip to Cork," in Legends, Tales and Stories from Ireland (Dublin: John Cumming, 1837), 260-273.
} 
superstition. The stories in this two volume set focused on the Irish legends of fairies, spirits and little people and the firm belief that these mythical creatures existed and interacted with humans.

This depiction of Irish culture was reinforced by the media. ${ }^{66}$ In April of 1827, The Dublin Evening Mail reported that a woman had drowned her child and claimed her innocence because she was only trying to drive the fairy spirits from the girl. ${ }^{67}$ These reports reflected the primitive belief system of the Irish and their simple understanding of the world. Older, more harsh medieval and Renaissance accounts of these children were “false and unjust estimates” of their character. They were the "most pleasing of peasantry in Europe.” ${ }^{68}$ Father Vincent Glover, parish priest for St. Peter’s Catholic Church in Liverpool stressed the important role that education and training should have in order to raise the standards of the Irish to the English level of civilization. ${ }^{69}$ The responsibility for uplifting these primitive souls lay, according to the Glasgow Courier, "as much at our door as it does at the door of the people of Ireland.”70

The short-lived newspaper, The Black Dwarf, was a staunch supporter of Ireland in the first two decades of the nineteenth century and gave the English public a perspective of the intense poverty and socio-political injustices occurring in Ireland. Published by Thomas Jonathan Wooler, it was a satirical radical journal that began as an eight page newspaper and later expanded to a thirty-two page pamphlet. By 1819 it was selling roughly 12,000 issues per publication. In contrast, the more reputable upper-

\footnotetext{
${ }^{66}$ Thomas Croften Croker, Fairy Legends and Traditions in the South of Ireland (London: John Murray, 1828).

${ }^{67}$ The Dublin Evening Mail, April 18, 1827.

68 "Art. II.-Observations on the State of Ireland, principally directed to its Agriculture and Rural Population; in a Series of Letters, written on a Tour through that country,” Edinburgh Monthly Review 1:6 (June 1819): 643-644.

${ }^{69}$ Great Britain, Report on the State of the Irish Poor in Great Britain, House of Commons, 40, 1836: 22.

${ }^{70}$ The Glasgow Courier, November 11, 1827.
} 
middle class journal Blackwood's Magazine sold roughly 4,000 copies per issue. ${ }^{71}$

Wooler, a printer from Yorkshire who had gotten involved in the radical political

movements of the day when he moved to London, used his paper as a platform for radical issues, from the right of the poor to reclaim wastelands to taxation and rents. By the early 1820s, Ireland's problems, from the extreme poverty to famine, became a central focus in the Black Dwarf. In 1822, Wooler published an extensive article on a series of famines in the late 1810s in Ireland and England's lack of concern or response to the crisis. Ireland faced “deplorable want” and because of England's “despotic power” over the lives of the natives, they were without adequate food and other necessities. Wooler argued that the “grinding system of taxation and oppression" had left little but a "bare subsistence to the labouring classes.” ${ }^{72}$ By 1823 and 1824, his paper positioned Ireland as on the verge of rebellion because of the horrific conditions created by centuries of mismanagement and oppression. Wooler believed that only total revolution would bring sufficient change and end the suffering and misery of her people. ${ }^{73}$ The articles featured in The Black Dwarf continually pressed the issue of starvation, deprivation, poverty and oppression that was not only present Ireland, but also a long-standing facet of the socio-political context of the country. Wooler also emphasized England's role in creating these problems and his paper stressed England's obligation to Ireland to fix those same problems as well. Wooler

\footnotetext{
${ }^{71}$ Clement Boulton Roylance Kent, The English Radicals: A Historical Sketch (London: Longmans, Green and Co., 1899), 283-284; Laurel Brake and Marysa Demoor, Dictionary of Nineteenth Century Journalism in Great Britain and Ireland (Belgium: Academia Press, 2009), 57; The Black Dwarf ceased publication in 1824 after the death of its primary patron main patron Major John Cartwright. Also see: Paul Thomas Murphy, Toward a Working Class Canon: literary criticism in British working-class periodicals, 18161858 (Ohio: Ohio State University Press, 1994); Alex Bechimol, Intellectual Politics and Cultural Conflict in the Romantic Period: Scottish Whigs, English radicals and the making of the British public sphere (England: Ashgate Publishing, 2010).

${ }^{72}$ Thomas Wooler, "Inadequacy of the Subscription for the Relief of Famine in Ireland," Black Dwarf, June 5 1822: 794-795. (793-803).

${ }^{73}$ Thomas Wooler, "Progress of Revolution in Ireland," Black Dwarf, 11:18, October 29, 1823: 611-624;

“Independence of Ireland,” Black Dwarf, 12:9 (3 March, 1824), 286-289.
} 
was not the only publisher to express sentiments of support for Ireland in the early decades of the 1800s. Rather, it reflected a more broad sense of responsibility and concern for the people of Ireland that eroded among the middle class of England as the Great Famine became an entrenched crisis throughout the 1840s.

The harsh language indicative of Anglo-Irish relations in the later decades of the nineteenth century was distinctly absent in the early part of the century, in spite of the growing perception of the Irish as a problem for England. Although the people of Ireland were living in "wretched dreadful living conditions," they were seen as a "hapless people” to be "pitied by all other inhabitants of the British empire.” It was the duty of her neighbors to provide Ireland with "British benevolence" in order to raise her people to the standard of civilization as reflected in England. ${ }^{74}$ Economist George Wakefield argued that Great Britain was "destined to be the friend and protectress of Ireland" in the wake of the Act of Union. ${ }^{75}$ This paternal benevolence was, however, about to undergo a major challenge in the 1840s. A new movement, Chartism, began to take shape among the working classes. While its goal was emancipation of the working men of England, it encompassed many of the goals near and dear to the Irish immigrant population in England. As the Irish presence increased in this new, radical movement, the image of the simple peasant began to change.

\footnotetext{
74 "Art. II.-Observations on the State of Ireland, principally directed to its Agriculture and Rural Population; in a Series of Letters, written on a Tour through that country," 645, 650.

${ }^{75}$ George Wakefield quoted in William Hamilton Maxwell, History of the Irish Rebellion in 1788 (London: Baily Brothers, 1845), 337.
} 


\section{Chapter Two}

\section{Chartism}

Irish immigration into England did not begin with the Great Famine, but was instead a slow and steady trickle that would eventually become a deluge after the long years of starvation. Beginning in the late 1700s, Ireland experienced a population increase that put stress on its limited food supplies. Emigration became a response to this stress and the early decades of the 1800s would establish a pattern for Irish immigrants that would remain consistent throughout the century. Migratory labor travelled with the harvest seasons, and as these unskilled workers moved from the fields to the factories, they became permanent residents in English industrial towns. Cities such as London, Manchester, and Liverpool became home to growing numbers of Irish immigrants. By 1841, 17.6 percent of the population of London, 11.9 percent of Liverpool, and 8.3 percent of Manchester were Irish-born. ${ }^{1}$ 'Irish towns' became staples of poor neighborhoods in the industrial centers of England.

Often lacking any viable job skills and uneducated, these new immigrants filled the ranks of the impoverished unskilled labor pool. ${ }^{2}$ They became the bottom rung of the new industrial working class working for the lowest wages and under the worst conditions. It is, therefore, no coincidence that this segment of the working class was drawn to the Chartist movement throughout the first half of the century.

It was this involvement in Chartism that helped to redefine the Irish in the eyes of the English middle class. As poverty increased in the industrial centers and the living standards continued to fall, the Irish were drawn to the Chartist's promises of universal

\footnotetext{
${ }^{1}$ Great Britain, “Census of Population,” Parliamentary Papers, (London: G. Luxford, 1842), 366.

${ }^{2}$ As late as 1851, the census in Ireland indicated that only half of the population was literate in English.
} 
suffrage, land equity and improved education. As Chartism emerged from the fringes of the industrial north and the artisan south and became a national movement, fractures in the upper echelons developed over the approach the movement needed to take in order to facilitate change. This fracture divided the Chartists into two camps- one promoting change within the political structure and one promoting more aggressive, confrontational tactics. The leader of the more contentious faction, Feargus O'Connor, was schooled in the methodology of Irish rebellion and discontent. The English middle class, already wary of Chartist demands, quickly identified the violence with the Irish, thus upsetting the previously benign image of the Irish as quaint and humble peasant folk.

\section{The Historiography of the Movement}

The historiography of Chartism begins with the embittered ex-Chartists who were left to analyze the failure of what was supposed to be the beginning of a new era for England. Robert George Gammage reflected on his involvement in the movement and its demise from infighting in his 1894 work The History of the Chartist Movement. His became the received account of events for decades. ${ }^{3}$ Earlier works by William Lovett and Thomas Cooper, written during the movement's heyday, had already hinted at the discord growing amongst the most powerful of the movement's leaders. ${ }^{4}$ They framed the movement in euphoric, almost utopian language and placed the blame of failure squarely on the shoulders of the organizational rift in methodology. In his 1894 work, Gammage praised Lovett as the "body and soul" of the London Chartists. ${ }^{5}$ In contrast, he described Feargus O’Connor as a man to be "classed among cowards and poltroons" to be met only

\footnotetext{
${ }^{3}$ Robert George Gammage, The History of the Chartist Movement, 1837-1854 (Newcastle-on-Tyne: Browne \& Browne, 1894).

${ }^{4}$ William Lovett wrote Chartism: A New Organization for the People in 1840 and Thomas Cooper wrote a number of essays, editorials and poetry selections during the 1840s.

${ }^{5}$ Gammage, The History of the Chartist Movement, 10.
} 
with "scorn and derision.” Gammage makes numerous references to his Irish background and refers to him as a man "suited to strife” given his upbringing in Ireland. ${ }^{6}$ For Gammage, these two men served as the counterpoints in the demise of Chartism. O’Connor's activities in the north, such as the Newport Rising, were portrayed as foolish adventures having little to do with Chartism and its goals. He and the other embittered former members stressed the tension and divisions among personalities at the top as critical to the end to the movement, with O’Connor taking a beating for his aggressive politics during the era.

The second wave of historians took a broader perspective on the movement. These were men not directly involved in the struggle and they viewed the movement from a broader social and economic context. Like the first generation, they too argued that personal conflicts were instrumental in the demise of the movement, but they stressed that these personality differences reflected a much larger sociological incompatibility. Southern leaders from London like Lovett, according to historian Mark Hovell, held very different views on the approach to change than their northern, industrial compatriots such as O’Connor. The London chapters evolved, according to Hovell, from non-political Owenism and were founded on the belief that "democracy is the necessary preliminary to social equity and justice.”7 The northern industrialists, under the tutelage of Feargus O’Connor, were agitating for strikes and they made no secret of their use of force when deemed necessary. Hovell argued that it was a conflict between the "sincere, self-sacrificing... London artisans" who were working men sharing their "best aspirations” and the "blustering, egotistical, blarneying, managing, but intellectually and

\footnotetext{
${ }^{6}$ Ibid, 13-14.

${ }^{7}$ Mark Hovell, The Chartist Movement (Manchester: University Press, 1918), 52.
} 
morally very unreliable Irishman,” who very likely had “never done an honest day’s work in his life." ${ }^{8}$ Hovell's work, while groundbreaking in its regional analysis as opposed to simple personality conflicts, was heavily influenced by the lingering racism against the Irish. The Easter Uprising was only two years old at the publication of his work, and the view of the Irish as traitors was still fresh in English minds. The unskilled Irish faction of the movement, according to Hovell, served as a violent tool for O’Connor to use as he saw fit.

By the 1940s, new directions in the analysis of Chartism emerged, but the conclusions of previous scholars were still quite prominent. G.D.H. Cole, in his landmark work A Short History of The British Working Class Movement, 1789-1947 originally published in 1948, argued that Chartism was merely an economic movement with a purely political program, and thus doomed to infighting and conflict concerning tactics. ${ }^{9}$ Like Hovell, Cole emphasized the political distinctions between North and South as instruments in the inevitable internal conflicts. The British historian Asa Briggs in his seminal collection of essays titled Chartist Studies in 1959, also reiterated Hovell's analysis of the movement as rife with regional differences. Like Hovell, the essays focused on the diverging viewpoints between the northern industrialists under O’Connor's leadership and the southern artisans under Lovett. The new scholarship these essays added centered on the local origins of the movement as well as its demise. The general premise of the collection highlighted the important role local moderate factions played in the development of a national movement while downplaying the violence as the most significant contribution to effective change. Brigg's later work throughout the 1960s

\footnotetext{
${ }^{8}$ Ibid, 67.

${ }^{9}$ G.D.H. Cole, A Short History of The British Working Class Movement, 1789-1947 (London: Routledge, 2001).
} 
continued this line of analysis, particularly after the publication of E.P. Thompson's groundbreaking work The Making of the English Working Class. Class divisions became the central focus of conflict not only in the Chartist movement, but throughout English history as a whole. Chartism, according to Briggs, was merely one facet of Thompson's larger class struggle. ${ }^{10}$

By the end of the 1960s and into the 1970s historians started shifting the focus away from regional differences. Historians such as Iowerth Prothero, David Goodway, Dorothy Thompson and W.H. Maehl all argue that the regional differences were not as distinct as earlier analysis suggests. ${ }^{11}$ London was not as conservative as Hovell presented and areas such as Lancashire in the North were far less radical and violent than originally thought. Prothero, in his important work on Chartism in London for example, argues that earlier studies of London focused on the late 1830s, when apathy was the prevailing mentality among the urban communities. By the early 1840 s, however, a National Convention in the city fanned the flames of discontent and after that, clashes with the police increased and huge crowds gathered at meetings that often ended in violence. His work directly contradicts Howell and Briggs and brings London into line with the more radical and aggressive tactics of the northern industrial Chartists. ${ }^{12}$

In the 1980s, historians began looking at Chartism as a far more complex, dynamic movement than previously thought. Gareth Stedman Jones and Dorothy Thompson both released monographs in an eighteen month period that provided new

\footnotetext{
${ }^{10}$ E.P. Thompson, The Making of the English Working Class (New York: Vintage, 1963).

${ }^{11}$ Patrick Joyce, Work, Society and Politics: the culture of the factory in later Victorian England (New Jersey: Rutgers University Press, 1980); David Goodway, "Chartism in London,” Bulletin for the Society for the Study of Labour History 20 (1970); Dorothy Thompson, "Chartism as a historical subject," Bulletin of the Society for the Study of Labour History, xx (1970); W. H. Maehl, "The dynamics of violence in Chartism: a case study in northeastern England,” Albion, vii (1975), 101-119.

${ }^{12}$ Iorworth Prothero, “Chartism in London,” Past and Present, 44 (August, 1969): 81.
} 
insight into the movement. Jones, in his work Languages of Class: Studies in English Working Class History, 1832-1982 posited that Chartism was not, as earlier historians stressed, a regionally divided movement, but was instead a national movement created and shaped entirely by ideas. Influenced by post-modern theory and cultural studies, he acknowledges that there were differences in leadership, but these were not the destructive forces that tore the movement apart as once thought. While Hovell argued that Chartism was a "protest against what existed," Jones argued for far more complex motivations in the socio-political movement, including wage issues, access to the political process, and class conflicts. ${ }^{13}$ He concluded that Chartist arguments were rooted in a traditional attack on the opulence and corruption of the political system. Its early success, according to Jones, rested in the use of the older language of radicalism and the techniques leaders used in adapting that language to the growing discontent of the 1830s and 1840s. The movement was not, however, prepared for the Peel government's reaction to its demands. As Sir Robert Peel's government began their social and economic reform legislation in the 1840s without actually reforming Parliament, the link that Chartist leaders had forged between economic deprivation and political power slowly dissolved, and as the 1840s came to a close the movement died. Jones' work was one of the first major monographs to diverge from class as the central focus of the Chartist movement to the idea of the power of the language of radicalism and the adaptation of older ideas for a new era.

Thompson's work, The Chartists: Popular Politics in the Industrial Revolution was published soon after Jones' and could not, therefore, address his arguments. It does, however, synthesize her arguments from prior decades into a unified thematic analysis of Chartism. In 1969, she first expressed a number of reservations with then current trends

\footnotetext{
${ }^{13}$ Hovell, The Chartist Movement, 7.
} 
in the analysis of Chartism. She argued that the proliferation of local studies had reinforced the notion that Chartism was nothing more than a protest movement. This regionalism failed to acknowledge the articulate and disciplined nature of Chartist writing, speaking and organization, thus disregarding the rational, nation-wide appeal of certain principles the movement espoused. Her 1984 work covered a much larger time frame, beginning the Chartist narrative in the early 1830s rather than just the decade of the 40s at its height. The critical issue, she argued, was the evolution of the movement in itself. Using E.P Thompson's theory of a moral economy, she argued that for centuries workers responded to wage crises and food shortages with protests, rioting or begging. In the early 1830s, however, grassroots socio-political groups emerged in response to the current crises rather than the more traditional responses. She posited that Chartism was the outgrowth of a literate and sophisticated working class, very different from the peasant classes of previous generations and represented a break with the past. The movement was not just a response to food shortages, but also a direct response to increasing centralized government policies, influenced by philosophical radicals and political economists of the period. This response was forged around a common language taken from the intellectual theories of the elite, and what developed was a socio-political organization based on an articulate political and social platform. Unlike Jones, who set his analysis within a moderate liberal historiographical tradition and thus downplayed the political nature of Chartism, Thompson's work placed the political facet of the movement directly in the forefront of her thesis, but she firmly agreed with Jones' perspective that Chartism was far more than just a protest movement of the period. 
Throughout the 1970s, David Goodway continued to refine his arguments on Chartism and in his 1982 work London Chartism, 1838-1848, he too stressed the complex motivations and shifting forces within the organizations rather than viewing Chartism as only a protest movement. His work focuses on his 1970 thesis centering on the more radical edge to the London chapters. He argues that for the Chartists to have any lasting impact on the existing order, they needed the support of London as it was the seat of government and the focal point for the ruling classes of England. It was problematic however, as Goodway provides a well-documented portrait of the motley collection of artisans and working class tradesmen throughout the city. This diversity, however, worked to the Chartists advantage because, according to Goodway, they were closer in spirit to the radicalism of earlier decades. After the initial influence of Lovett and the London Working Men's Association waned, Chartist followers did not turn their support to the London Democratic Association representing the far left of Chartism, but were instead drawn toward the more mainstream views of O’Connor. This argument is similar to James Epstein's view of the Irish leader as a unifying force between North and South rather than a divisive one. This perspective clashes with the London Chartists' analysis of O’Connor and provides a more complex picture of the Irish leader. Goodway's London Chartists were, on the whole, rationalist and anti-Christian and a small faction even favored the aggressive tactics of their northern compatriots. London was therefore, closer to the attitudes and beliefs of the North than earlier studies indicated, thus providing a far more national framework for the Chartist movement. Rather than internal conflicts, he argues, like Jones, that the movement failed for much more complex reasons. London, he stressed, mobilized slower than the north and peaked as a socio-political force as the 
strength of the movement in the northern regions was in decline. As a national

movement, Chartism did not present a unified front across the nation in a consistent manner and therefore failed to garner the clout necessary to achieve the kind of radical change they sought. ${ }^{14}$

James Epstein’s biography of Feargus O’Connor, published in 1982, entitled The Lion of Freedom: Feargus O'Connor and the Chartist Movement, 1832-1842, served as a single example of counter-analysis to Hovell’s 1918 work deriding the Irish contingency within the movement. ${ }^{15}$ Epstein's premise is that 1842 marked a watershed in the history of popular radicalism in England, and that in the decades to follow, the power of the masses as a political tool declined considerably. Like Jones, Epstein traces the ideology of Chartism back to the older traditions of radicalism and he argues that the movement was in reality a culmination of the many democratic organizations and trends of prior decades. However, Chartism was unique according to Epstein because its leaders, most notably O’Connor had a firm understanding of not only the realities of class exploitation but also the critical need for a political party distinctly for the working class. He positions O’Connor not a divisive character in the development of Chartism, but as a unifier between North and South. Once O’Connor parted company with the Irish leader Daniel O'Connell 1836, he assumed a greater role in the national Chartist leadership. O’Connor represented the consolidation of the political platform and the power of the press through his through his extensive national speaking tours and the newspaper, The Northern Star, which carried most of his speeches and featured Chartist activity on a national scale. It

\footnotetext{
${ }^{14}$ David Goodway, London Chartism, 1838-1848 (New York: Cambridge University Press, 1982).

${ }^{15}$ James Epstein, The Lion of Freedom: Feargus O'Connor and the Chartist Movement, 1832-1842 (London: Croom Helm, 1982). Also see: John Belchem, “1848: Feargus O'Connor and the collapse of the mass platform,” in The Chartist Experience, eds. Epstein and Thompson (London: Macmillion, 1982).
} 
was this representation, Epstein argues, that allowed O'Connor to play a vital role in the National Convention of 1839 that shaped the ideological goals in later years. Unlike Hovell, who postulated personal theories about O'Connor's thoughts and action, Epstein resigns the powerful leader's motivations to history concerning his role in the growing violence of the North and his increasing distance from the national leadership in the early 1840s. There is simply not enough evidence to make sound conclusions. This biography is the only modern examination of particular individuals within the movement and the role of personality in shaping the goals and ambitions of the Chartist movement on a national scale. It is, therefore, a critical work in analyzing the impact of the powerful leaders in defining the tenor of Chartist rhetoric and ideology.

\section{Gaps in the Current Historiography}

As important as the major studies produced by Dorothy Thompson and Gareth Stedman Jones and the supporting work from other historians such as Goodway and Epstein are, they have failed to generate any agreement about a new perspective on Chartism nor have these works produced a new wave of historiography on Chartism as a whole. Much of the important work in recent years has been centered in one of two areas: the culmination of research from the 1980s and work on late Chartism and its decline, neither of which has produced a great deal of original research. The major exception to these two trends has been studies of Chartism in relation to gender. In the mid-1980s and early 1990s, Barbara Taylor, Catherine Hall and Joan Wallach Scott all raised questions about the problematic role of women in predominantly male public movements, Chartism included. ${ }^{16}$ Wallach Scott, for example, targets E. P. Thompson's seminal work due to its

\footnotetext{
16 Barbara Taylor, Eve and the New Jerusalem. Socialism and Feminism in the Nineteenth Century (Harvard: Harvard University Press, 1993); Catherine Hall, “The tale of Samuel and Jemima: Gender and
} 
peculiar analysis of women in the narrative of class struggle. These historians all argue that women did have some role in these movements and even their absence in certain instances was a significant point of analysis. Apart from this distinct facet of research centering on gender and its relationship to Chartism, there has been little in the way of new analysis and fresh perspectives.

Other than passing references throughout the historiography of Chartism, the actual question of the Irish element within the movement has not been thoroughly addressed. Hovell and Epstein battled over O’Connor as a leader, but how did his Irish heritage factor in his leadership? How did the insurrectionary spirit of Ireland translate in an English socio-political movement? As the Irish immigrants increased in the English urban ghettos, did Irish involvement in Chartism influence the perception of these newcomers? How did the view of Chartism as a violent threat to social order connect to the image of the later violent Fenian invading English shores? These questions have yet to be thoroughly addressed in Chartist historiography and they are critical in understanding not only the Irish within the movement itself, but also the Irish within English society as a whole. Chartism as a radical movement played a significant role in the socio-political landscape of England during the 1830s and 1840s. It is therefore vital to understand the role the Irish specifically played in order to properly analyze the shifting perceptions and viewpoints on this immigrant group in later decades.

Working Class Culture in early Nineteenth Century England” in White, male and Middle Class: Explorations in Feminism and History (Oxford: Oxford University Press, 1992); Joan Wallach Scott, "On language, gender and working class history,” International Labor and Working Class History, XXXI (1987), 1-13. 


\section{The Origins of the Movement}

English Chartism evolved from a variety of earlier radical movements from the later 1700s and early 1800s. In 1824 and 1825, the Combination Acts, which made 'combining' or organizing in order to gain better working conditions illegal, were repealed, thus legalizing trade unions. This allowed these early groups to legally gather and they began agitating for political and social reforms from Parliament. Formed in 1828, John Doherty’s Grand Union of Operative Spinners for example, took on the formable task of preventing reductions in wages among the working class and fought to lessen factory hours in order to improve working conditions. Doherty tried again and broadened the scope of this second attempt with The National Association for the Protection of Labour, established in 1830. This first trade union in England was established to improve the general working conditions in factories across the country. The union even established a newspaper, United Trades Co-operative Journal. While it was unsuccessful, the second attempt, The Voice of the People, established in 1831, was much larger in scope. Its intention was to "unite the productive classes of the community in one common bond of union." ${ }^{17}$

Another early reformist movement that made a lasting impact on the structure and organization of later movements, including Chartism, was Owenism. Robert Owen was a manager and partner in two large cotton mills. He got his start in business in a plant in Manchester and after successfully establishing himself as a prominent businessman, he convinced his partners to buy a second plant in Lanarkshire, Scotland. It was in this poverty-stricken region that he would find his calling as a social reformer. There were

\footnotetext{
${ }^{17}$ Beatrice and Sidney Webb, History of Trade Unionism (London: Longman, Green and Co, 1894), 120 124.
} 
2,000 inhabitants of New Lanark and although the workers had not been mistreated by the former owner, their living conditions were harsh. Owen improved the houses and through his own personal influence and example, encouraged the people in habits of order, cleanliness, and thrift. ${ }^{18}$

Owen's work in New Lanark set a new standard for reform measures as he continued to lobby for further changes. His agitation for factory reform met with little success and he began to move in a more philosophical direction with his philanthropy. He argued that the competition of human labor with machinery was a permanent cause of distress and that the only effective remedy lay in the united action of men and the subordination of machinery to man. His proposals for the treatment of pauperism were based on those principles and he wanted to create villages of "unity and cooperation" for the unemployed. ${ }^{19}$

Although his villages never materialized in the fashion he imagined, he continued to fight for a transformation of the social order in order to initiate massive changes. His proposals for communities attracted the younger workers brought up under the factory system, and between 1820 and 1830 numerous societies were formed and journals organized to advocate his views. Owen's doctrines were accepted by labor unionism as a working class perspective emerged in the factories across England. Owen and his followers carried on ardent propaganda all over the country, and this effort resulted in the transformation of the new National Operative Builders Union into a guild and the establishment of the Grand National Consolidated Trades Union in $1834 .{ }^{20}$ Although the

\footnotetext{
${ }^{18}$ Robert Owen and John Brindley, What is Socialism?: and what would be its practical effects on society (London: Home Colonization Society, 1841), 13.

${ }^{19}$ Robert Owen, The Life of Robert Owen: Volume I (England: Wilson, 1858), 83.

${ }^{20}$ Joseph Clayton, Robert Owen: Pioneer Of Social Reform (England: A. C. Fifield, 1908), 27.
} 
early enthusiasm of the unions was strong, determined opposition by employers and severe repression by the government and courts ended the movement within a few months. Despite the failure, Owen's ideals of the rights of the worker had become firmly entrenched among the English working class and these ideals fermented the discontent that led to the Chartist movement just a few short years later. ${ }^{21}$

\section{The Reform Act and Its Failures}

While these various organizations, and countless other less formally organized ones, met with varied measures of success, their legacy of political activism became the foundation for new movements that formed in the wake of the Reform Act of 1832 . The Reform Bill gave the vote to a section of the male middle class, but not to the working class. Thomas Cooper, one of the early Chartists, stressed that the "poor and labouring classes... now mutter discontent... or openly curse" in the face of "grinding tyrannies of the recreant middle-classes” who abused their "cold, unfeeling... power” over the lower classes. $^{22}$ After the Reform Act passed, only one person in every eighty-three was qualified to vote because of property qualifications and other restrictions and those votes were cast without the benefit of a secret ballot. Sitting in Parliament was still also restricted to those with an income from property of at least $£ 600$ per year in the county constituencies and $£ 300$ in the boroughs. Future Chartist leader Feargus O’Connor was forced to give up his seat in 1835 because he did not meet the property requirements. ${ }^{23}$ Feeling betrayed, the working class began to unify their efforts in an attempt to pressure

\footnotetext{
${ }^{21}$ Ian L. Donnachie and George Hewitt, Historic New Lanark: The Dale and Owen Industrial Community Since 1785 (Scotland: Edinburgh University Press, 1993 ), 59, 66, 73-77; John Harrison, Robert Owen and the Owenites In Britain and America (New York: Taylor \& Francis, 2009), 176.

22 Thomas Cooper, Wise Saws and Modern Instances: Volume II (London: Jeremiah How, 1845,) 12.

${ }^{23}$ S. J. Connolly, “The Great Famine and Irish Politics,” in The Great Irish Famine, ed. Cathal Póirtéir (Dublin: Mercier Press, 1995), 35.
} 
the government toward greater freedoms. New organizations sprang up around the country. In 1836, William Lovett formed the London Working Men’s Association. The East London Democratic Association was formed a year later. Around the same time, the Marylebone Radical Association, under the tutelage of Feargus O’Connor, was formed in the north of England. Thomas Attwood's Birmingham Political Union had disbanded in 1832, but found new lifeblood in 1837 in the post-Reform Act years.

Many of these groups were driven by opposition to what they saw as the repressive measures of the middle class supported Whig government, including shutting down the unstamped radical press and the repressive measures against trade unions. This government was supported by the middle class, and deep ideological divisions developed between the middle and working classes. The first division was the Reform Act of 1832 and then the trade unions took a serious blow after the Tolpuddle incident. After the Reform Act failed to expand the franchise to the working class, six men from Tolpuddle in Dorset, led by local Methodist preacher George Loveless, founded the Friendly Society of Agricultural Labourers to protest the gradual reduction of agricultural wages in the early 1830s. They refused to work for less than ten shillings a week, although wages had been reduced to seven shillings a week and were due to be further reduced to six shillings. In 1834 James Frampton, a local landowner, wrote to the Prime Minister, Lord Melbourne, to complain about the union. He invoked an obscure law from 1797 that prohibited people from swearing oaths to each other, which the members of the Friendly Society had done. James Brine, James Hammett, George Loveless, George's brother James Loveless, Thomas Standfield, and Thomas's son John Standfield were arrested, found guilty, and transported to Australia. The local working people made popular heroes 
of the men, and by 1837, with the support of newly appointed Home Secretary Lord John Russell, they were all released. ${ }^{24}$ With anger rising over the Reform Act, these arrests and convictions were seen as a clear miscarriage of justice among the working class. The middle class, however, largely disagreed and a deep riff began to emerge between the middle class and working class trade union members. The disagreements over these serious issues resulted in an exodus of the middle class artisans from the fledging unions and the working class quickly became the new backbone of reform movements.

In addition to these two major issues, other failures were driving these organizations and radical demands seemed imminent. In 1833, the Factory Act addressed the terrible problem of child labor and working conditions, but left adults completely out of any and all improvements. In 1834, the new Poor Laws were enacted across England in the midst of an economic slump, and they were not welcome in the northern industrial centers faced with tough times. In 1838, with the growing support of this angry segment of the population, William Lovett formed a committee and the People's Charter was written as a focal point for six essential points. The first issue centered on universal male suffrage "for every man twenty-one years of age, of sound mind, and not undergoing punishment for crime.” The Chartists were demanding a political voice for all men and in their second point, they stressed the importance of the secret ballet in protecting all electors in the exercise of the vote. While the vote was a critical measure in sharing political power, the Chartists also stressed that the property qualifications for Members of Parliament needed to be eliminated as well. Representatives, they argued, should reflect

\footnotetext{
${ }^{24}$ For further discussion on this event see: Herbert Vere Evatt, The Tolpuddle Martyrs: Injustice within the Law (Australia: Sydney University Press, 2009); Joyce Marlow, The Tolpuddle Martyrs (Michigan: University of Michigan Press, 1971); George Loveless, Tolpuddle: An Historical Account Through the Eyes of George Loveless (England: Trade Union Congress, 1984).
} 
the broad scope of the population, not just the landed wealthy. Once an "honest

tradesman, working man, or other person” was actually elected, the Chartists wanted each Member of Parliament to receive a salary so that "when taken from his business," the working man could earn a living while attending to the "interests of the Country.” They were also fighting for equal constituencies in order to create a balance of power in Parliament to prevent small, wealthy groups from overwhelming the votes of larger, less influential ones. The final demand focused on the number of sessions of Parliament. The Chartists argued that annual parliaments would be the "most effectual check to bribery and intimidation” because under the current system, a constituency "might be bought once in seven years (even with the ballot)," but under a system of universal suffrage, members with yearly elections, "would not be able to defy and betray their constituents as now."25

\section{Chartist Demands}

These demands were extremely broad in their scope. The Chartists argued that the concept of universal suffrage, for example, should include Irish Catholics as well as the larger working class population of the United Kingdom. Initially, these were the Irish of England, but as the Chartist movement began to identify with the Irish nationalists, some argued for broader demands in both nations. Starting in 1766 with the Papal recognition of the Hanoverian dynasty as lawful rulers of the United Kingdom, the English kings had slowly begun easing restrictions on the Catholic minority across the nation. With the Act of Union in 1800, the issue took on an entirely new political framework as Ireland became a full-fledged member of the United Kingdom, thus in theory losing its long-

\footnotetext{
${ }^{25}$ The Six Points of the People's Charter. Taken from a broadsheet published in 1838. Accessed July 12 2010 http://web.bham.ac.uk/1848/document/peoplech.htm.
} 
standing colonial status. However, the union raised the question as to the voting rights of millions of Catholics in Ireland as the Irish Parliament was dissolved and seats were added to the Westminster Parliament for the representatives from the newly absorbed nation. With King George III’s continued opposition, however, the Catholic vote was stymied for almost three decades. By the late 1820s, however, the monarchy had changed hands, and Daniel O’Connell's agitation brought the issue of Catholic Emancipation to the forefront of English politics. Under the growing pressure from the Catholic Association, Catholics were finally given representation in the English government. However, like the working class English, the lower class Irish remained disenfranchised. Individuals who could vote under the old laws suddenly found themselves disenfranchised as well due to changes in the property requirements for voters. With Catholic Emancipation in 1829, new property requirements were added. Suddenly large numbers of the Irish working class were shut out of the political process and became disillusioned with Daniel O’Connell's unfulfilled promises. They were looking for another outlet for their growing frustration with the entrenched systems of political injustices. Thus, when the Chartist movement began agitating for universal male suffrage and the elimination of property requirements, the working class Irish quickly identified with the struggle.

\section{Chartism, the Irish and Radical Movements}

This identification of the Irish with radical movements began long before the advent of Chartism. Although there had been a variety of organized groups fighting English rule in Ireland over the centuries, most notably the United Irishmen in the late 1700s, it was the Catholic Association that gave the Irish their first taste of real political 
power in the 1800s. The Catholic Association was founded in 1823 by politician and future leader of the Irish political landscape Daniel O’Connell. Initially, it was composed mainly of the middle-class elite as the annual subscription amounted to a guinea, and that was approximately six months of rent for the average Irish farmer. ${ }^{26}$ In 1824 , the association began using its money to campaign for Catholic Emancipation. That same year, a new category of associate member was created only costing one penny a month. This new membership was dubbed the Catholic rent and it was designed to increase membership considerably. ${ }^{27}$ This new, cheaper category allowed less prosperous Catholics to join and as a result, the initial class barriers were removed.

The Catholic rent transformed the association. First, it gave the Catholic Association a constant source of money which enabled O’Connell to run a consistent, well-financed campaign for Parliament. Second, it facilitated easy calculation of total association membership numbers so that O’Connell could say with confidence that he had the support of so many people. This was vital as it could be used to apply pressure against the British government by proving the strength of the Irish Catholic cause with hard data. Third, and perhaps most importantly, it was the first time the concept of mass mobilization was used. The Catholic Association became a powerful, populist organization among the Irish Catholic community and, according to historian Robert Dunlop, “called a nation into existence.," 28

The Association threw its weight behind Daniel O’Connell. When O'Connell won in the County Clare by-election in 1828, trouble began because he was a Catholic and

\footnotetext{
${ }^{26}$ Robert Dunlop, Daniel O'Connell and the Revival of National Life in Ireland (England: G.P. Putnam, 1900), 136.

${ }^{27}$ Ibid, 185.

${ }^{28}$ Daniel O’Connell, Ireland and O’Connell (England: Tait, 1835), 25-27, 30; Robert Dunlop, Daniel

O'Connell and the Revival of National Life in Ireland, (England: G. Putnam, 1900), 143.
} 
could not legally take his seat in parliament. This meant that County Clare had no representation in Parliament whatsoever. Sir Robert Peel and the Duke of Wellington recognized that if O’Connell were not allowed to take his seat, there could be widespread violence and possible revolution in Ireland. Peel announced he was going to put his support behind the Catholic Emancipation issue and tried to push through the new Catholic Relief Bill in February 1829. The bill was passed. It was a momentous victory not only for O'Connell, but for the power of Irish mass politics as well.

The Catholic Association was not the only reform movement for the Irish in both England and Ireland and Chartism was, therefore, a natural extension of this working class activity. John Doherty, for instance, was a leading trade unionist and in 1829, he helped to organize the first general union among the Lancashire cotton spinners. Thomas Sexton and Peter Curran were also prominent trade union leaders. William Thompson wrote two influential works on the economic conditions of the working class, both reflecting ideas later found in Marx and Engels. Unions were also flourishing in many Dublin trades and in other large Irish cities. From 1830 through 1832, tradesmen in Dublin, Cork and other Irish towns held demonstrations and meetings in favor of Repeal of the Union. ${ }^{29}$ Thus, new Irish immigrants often arrived with a sense of organization and the spirit of union rebellion. As the Chartists agitated for national issues that would have a profound effect upon the Irish working class, they began bringing their experiences to the movement.

\footnotetext{
${ }^{29}$ Sidney and Beatrice Webb, The History of Trade Unionism (London: Longmans, Green and Co., 1902), 104.
} 


\section{Irish Leadership}

Rising quickly among the ranks, Irish workers began occupying key roles within the Chartism movement, and thus had a powerful influence on the shape of the organization's agenda. James Bronterre O’Brien began to shape the ideology of the movement and Feargus O’Connor had a correspondingly important place in leading the masses. Much of O’Connor's attention focused on building a united mass movement. In 1836, he created the Central Association in London, but it was not until 1841, with the foundation of the National Chartist Association (N.C.A.) that he succeeded in creating a large-scale organization capable of achieving significant political ends. He was convinced that leadership needed to be concentrated in a small but dedicated body of men with himself at the helm. In order to secure his goals, he pushed through the election of several Irish Chartists to the Executive Committee who were loyal to him and to his policies. Those elected included a number of Manchester Irish Chartists, as O’Connor's philosophies, such as fair wages and working conditions, had found support among the factories in the industrial north. Among them were James Campbell, who became Secretary of the N.C.A. from its creation in 1841 until the fall of 1842 and Thomas Clarke and Christopher Doyle who were leading members of the Executive from 1843 until $1850 .{ }^{30}$

\section{Reaching out to the Irish}

The Chartist Movement seized upon the growing Irish dissent in order to draw them into their cause. Rather than ostracize the Irish immigrants, the radicals chose instead to seek their support for the larger cause of working class reform. The Chartists

\footnotetext{
${ }^{30}$ Frederic Boase, Modern English Biography (London: Netherton and Worth, 1897), 1207; Edward Royle, Chartism (London: Longman, 1996), 71.
} 
also advocated for reform for Ireland as well arguing that economic and social improvement across the sea would also be a boon for the working class of England. ProIrish rhetoric appeared in their literature as the "most degraded in the scale of nations" was an "awful spectacle.” The Chartists urged the Irish, for love of country, to unite with the Chartist cause for freedom for all. ${ }^{31}$ As early as 1839, O’Connor urged the Chartist Convention to consider the best means of "enlisting the support of the Irish people in the furtherance of the People's Charter” ${ }^{32}$ In the Northern Star, O’Connor constantly advocated such a union. In 1846, Thomas Clarke, a leading member of the Executive and an Irishman, made a new appeal on behalf of the Chartist Convention to the Irish nationalists to unite with them, since "co- operation strengthens the hand of labour, and enables us to make a stand against the power of monopoly.”33 These appeals met with a hostile reception from Irish national leaders until 1847, when O’Connor was elected a Member of Parliament for Nottingham. He threw his support behind the Irish demand for repeal and vocally expressed his opposition to coercive measures toward Ireland. He succeeded in winning the approval of a considerable section of the Irish Confederation, a group founded in 1847 for the sole purpose of achieving independence for the Irish nation by every means consistent with "human morality and reason.” ${ }^{34}$ Smith O’Brien, a prominent leader in the Irish nationalist movement, stated that he was "happy to think that there is amongst the middle and humbler classes of this country [England] a large amount of sympathy with Ireland . . . that amongst the Chartists [there] is scarce an individual who does not sympathise with the cause of Ireland .” He also formally

\footnotetext{
31 “Chartist Convention Placard, 5 April 1848," in Irish Migration in Britain 1815-1914: A Documentary History, ed. Roger Swift (Ireland: Cork University Press, 2002), 163-164.

${ }^{32}$ Northern Star, February 1839.

33 Ibid.

${ }^{34}$ Michael Doheny, The Felon's Track (Dublin, M.H. Gill and Son, 1920), 113.
} 
announced that "the repealers of Ireland will accept that aid which the Chartists are universally prepared to give them.”35 R.C. Gammage, in his History of the Chartist Movement, outlined the strategy within the movement toward the Irish to provide just such 'aid.' Meetings, particularly in Manchester, were designed to promote "fraternization of the Chartists and the Irish Repealers." Speeches were peppered with references to the fight for repeal and equated with the fight for workers’ rights. Gammage argued that if the two causes could be unified under the same banner, it would give strength to the more dominate issues of the Chartists. Once these tactics were employed, Chartist groups recorded an increase in "enrolled numbers" among the unskilled Irish laborers. ${ }^{36}$ In his history of the European Revolutions of 1848, author Edward Stillingfleet Cayley argued that Irish agitation was fuelled by the Chartist movement to further their own cause. The Chartists "sympathize[ed] with the Irish rebels" and this sympathy "found an echo in the bosoms of the Irish patriots." 37

The early antagonism between the Irish nationalist movement and Chartism has been a troubling aspect of the Irish involvement within the movement. There were clashes between English Chartists and the Irish working class in Manchester throughout 1841 and 1842. In his work The Lion of Freedom, James Epstein stresses that it would be a mistake to generalize about relations based on a single city. He does argue, however, that initially "the fragmentation within sections of the northern industrial working class, between Irish and English workers, was a source of Chartist weakness. ${ }^{\text {”3 }}$ Historians have

\footnotetext{
${ }^{35}$ Smith O'Brien, 10 April 1848 quoted in John Mitchel, The Crusade of the Period (London: Lynch, Cole \& Meehan, 1873), 270.

${ }^{36}$ Gammage, The History of the Chartist Movement, 296-299.

${ }^{37}$ Edward Stillingfleet Cayley, The European Revolutions of 1848, Volume III (London: Smith, Elder \& Co., 1856), 235; Donald Read, Feargus O’Connor: Irishman and Chartist (London: Arnold, 1961), 76.

${ }^{38}$ Epstein, The Lion of Freedom, 270-271.
} 
tended to focus on the antagonistic relationship between O’Connell and O’Connor and because of their ideological clashes, Irish immigrants remained aloof from Chartism. ${ }^{39}$ Following O’Connell's death in mid-1847, O’Connor and other Chartist leaders were able to make more direct appeals to Irish nationalists without interference or antagonism. This connection complicates the role of the Irish in England as there was support for Ireland and its causes. However, it is important to note that this support in the Chartist movement was among the working class, not the middle class rate-payer of England.

\section{Characteristics of the Irish Chartists}

A common trait among these new Irish Chartists was a devotion to Ireland and the cause of Irish nationality. The Chartists, however, had a different focus to their beliefs and issues than other Irish nationalists. They believed that as long as the true power of the state remained in the hands of a small, privileged minority, the masses would secure very little advantage from the restoration of Ireland's Parliament. Reform of the franchise, therefore, was paramount and needed to precede the Repeal of the Union. While the Chartists understood that in order to accomplish reform on this scale, unification between the English working-class and Irish nationalists was a necessity, there were nonetheless reservations. The more moderate leaders of the nationalist movement were not pleased with the new alliance as the Chartists were viewed as extremists, but Irish nationalists in Dublin and other towns endorsed the partnership. In Dublin, the Trades and Citizens Committee, composed of tradesmen and members of the Confederate Party sent a representative to the Chartist Convention of 1848. Irish nationalists, under a "green banner, with gilded edges, in centre an Irish harp” marched side by side with the Chartists

\footnotetext{
${ }^{39}$ For an in-depth analysis of O’Connell's policies and attitudes toward labor movements see: Oliver MacDonagh, The Emancipist. Daniel O’Connell 1830-1847 (London: Routledge), 1989.
} 
in a number of demonstrations throughout $1848 .{ }^{40}$ In July of the same year, a newspaper entitled The English Patriot and Irish Repealer began publication. Its editor and publisher was James Leach, an English Chartist and supporter of the alliance between the Irish nationalists and the Chartists. The paper firmly endorsed the view that the Irish and English should unite to support "the principles of Democratic Liberty."41

\section{The Impact of the Irish}

Although this alliance between nationalists and Chartists would not last, the Irish had an indelible influence on English Chartist policies. Seeped in a history of revolutionary politics, the Irish contingent put weight behind a more aggressive faction within the movement. Through the convictions of O’Connor and other prominent Irish leaders, the issue of the 'Irish question’ was thrust upon the larger English populous. Between 1841 and 1847, when O’Connor dominated the Chartist movement, efforts were made to break down the barriers of prejudice and misunderstanding which existed between the English and Irish working people. O’Connor frequently made use of the Northern Star to inform his readers on various aspects of life in Ireland, including the poverty and political oppression of its people. ${ }^{42}$ O’Connor had founded the Northern Star in 1837 in order to disseminate his radical political views. He secured the inclusion of Repeal of the Union in the second Chartist Petition of 1842 despite opposition from William Lovett and the Scottish Chartists and, when the repeal agitation was renewed in Ireland in 1843, O’Connor encouraged English working class radicals to agitate in

\footnotetext{
${ }^{40}$ Nation, April 15, 1848.

${ }^{41}$ The English Patriot and Irish Repealer, July 22, 1848.

42 Malcolm Chase, Chartism: A New History (England: Manchester University Press, 2007), 202, 299;

Donald Read, Feargus O’Connor: Irishman and Chartist (London: Arnold, 1961), 49.
} 
support. ${ }^{43}$ Irishmen were heavily involved in the grassroots political demonstrations favored by the movement. For example, Chartist demonstrations were held in many parts of England and Scotland in the spring and summer of 1843, and they were largely organized by Irishmen, but attended by English workmen.

\section{Edward 'Feargus' O'Connor's leadership and influence}

Edward 'Feargus' O’Connor was among the most prominent of all the Chartist leaders. Born into a prominent Irish Protestant family, he was the son of Irish nationalist politician Roger O’Connor (1762-1834). The elder O’Connor was a braggart and an ardent nationalist and the future Chartist leader grew up amidst tales of ancient familial glory and insurrection. Roger O’Connor claimed to be the direct descendant of the King of Ireland Ruaidrí Ua Conchobair, who ruled the island from 1116 to 1186, although there was never evidence to prove this claim. He was a legitimate member of the Irish Parliament from 1791 and 1795, a representative for Robert Emmet's rebellion in France and a long-time member of the United Irishmen with Emmet. With a background in law and an upbringing steeped in civil unrest, Feargus O’Connor emerged as a staunch advocate for Irish rights and democratic political reform. He was a notable critic of Parliament's policies on Ireland and in 1832, he was elected to the British House of Commons as an MP for County Cork, but was disqualified in 1835 because he failed to satisfy the property requirement for Members of Parliament. ${ }^{44}$ In 1837 he founded the Chartist newspaper the Northern Star and began his rise to prominence within the movement. As Chartism peaked in its power and influence in 1847, O’Connor was once again elected to Parliament as an MP for Nottingham and organized the Chartist meeting

\footnotetext{
${ }^{43}$ William Lovett, Life and Struggles of William Lovett in his pursuit of bread, knowledge and freedom (London: Trbner Publishing, 1876), 254.

${ }^{44}$ Read, Feargus O’Connor, 2.
} 
on Kennington Common in London the following year. His career continued in an erratic fashion and after insulting fellow lawyer Sir Edmund Beckett Denison, his radical political opinions were used to declare him a lunatic, and he was committed to an asylum in Chiswick, where he died in 1855 at the age of $61 .^{45}$

Although it is hard to estimate the extent to which rank-and-file English Chartists came to understand Irish problems and difficulties, there is evidence that O’Connor's propaganda campaign met with limited success. By 1848, when some limited measure of co-operation was achieved between the Chartists and the Irish Confederates, union with the Irish nationalists was supported by considerable numbers of Chartists in England. ${ }^{46}$ George Julian Harney, for example, admitted that at one time he had been filled with disgust at what he considered to be the wickedness and ignorance of Irishmen in representing England "as the natural oppressor of Ireland, and Englishmen as the enemy of the Irish people”. By 1848, however, he had recognized the truth of the assertion that "hatred, contempt and indifference towards the Irish people abound in English society."47 1848 was, as later chapters will analyze, a watershed year for violence, starvation, immigration and tension between the Irish and the English. After this point, there is a considerable shift in opinion among the middle class citizens of England that does not dramatically abate for the remainder of the century.

\section{The Growing Split and the Perceptions of the Irish}

In spite of the small inroads O’Connor managed to achieve, tension within the Chartist Movement was growing between the English and the small but growing number

\footnotetext{
${ }^{45}$ David Goodway, London Chartism, 1838-1848, (New York: Cambridge University Press, 1982); James Epstein, The Lion of Freedom: Feargus O'Connor and the Chartist Movement, 1832-1842, (London: Croom Helm, 1982).

${ }^{46}$ Read, Feargus O’Connor, 76-77.

${ }^{47}$ Northern Star, August 5, 1848.
} 
of Irish immigrants. Reports on the conditions in Irish areas began to filter out to the public and as Parliament reviewed the Poor Laws throughout the 1830s, the state of the Irish became an ever increasing concern. In 1832, Dr. James Phillips Kay Shuttleworth served as a doctor in the Manchester area during the cholera epidemics and he provided first-hand accounts of his time in the Irish slums. Dr. Shuttleworth first published a pamphlet highlighting the conditions of the Irish poor and then testified before Parliament as part of the investigations into the effectiveness of the Poor Laws. In his pamphlet, he made a number of observations on their squalid living conditions he observed during his battle against cholera in the poor neighborhoods throughout the city. He argued that the Irish "have taught the labouring classes ... a pernicious lesson [of] demoralization and barbarism." ${ }^{48}$ While the Irish were not the only poor people living in such conditions, this work set a precedent for the image of the immigrant as diseased and degenerate as Shuttleworth's work focused almost exclusively on the Irish sections of cities as they were the most disease-riddled and filthy. They lowered the standards of the hard-working Englishmen around them. ${ }^{49}$ In his report to Parliament, he described the large number of Irish beggars “in idleness and destitution” and those that were employed displayed a high degree of "apathy of character." ${ }^{50}$ The 1836 Report on the State of the Irish Poor was a Parliamentary report not only on the Irish in Ireland, but also those in England. The report echoed Dr. Shuttleworth’s findings of squalid living conditions, disease, and

\footnotetext{
${ }^{48}$ Dr. James Phillips Kay Shuttleworth, The Moral and Physical Condition of the Working Classes Employed in the Cotton Manufacture in Manchester, Second edition (London: Frank Cass and Co. Ltd., 1970), 21. This work was originally published in 1832 in response to a cholera epidemic in the city.

${ }^{49}$ M.A. Busteed and R.I Hodgson, "Irish Migrant Responses to Urban Life in Early Nineteenth-Century Manchester,” The Geographical Journal, Vol. 162, No. 2 (July: 1996): 141.

${ }^{50}$ Dr. James Phillips Kay Shuttleworth, First Annual Report of the Poor Law Commissioners For England and Wales (London: W. Clowes and Sons, 1835), 306.
} 
poverty. The image of the Irish as a disease-ridden menace was growing throughout England as the urban population of immigrants continued to rise.

As this tension escalated, the Irish influence in the Chartist movement did not go unnoticed by its critics. The movement as a whole was not popular with the bulk of the middle or upper classes of England and author Edward Stillingfleet Cayley argued, in quite broad terms, that the English "clearly did not want the Charter, or a revolution, or a provisional government" in any capacity. ${ }^{51}$ While he did not specifically define the term 'English,' his rhetoric was staunchly anti-Chartism and implied some level of consensus amidst the larger population. Discussion began to focus on the negative impact the Irish were having on an already negative movement.

In 1839, Thomas Carlyle, a satirical writer, essayist, historian, teacher and controversial social commentator, wrote his seminal work entitled Chartism. It was one of the first major treatises that offered reflection and analysis of the working class movement and offered an assessment of the current class conflict and working-class radicalism in Britain. In spite of the Northern Star's indictment that he knew nothing of Chartism, Carlyle nonetheless concluded that class conflict, and the Chartist response to that conflict, was bordering on a national crisis. ${ }^{52} \mathrm{He}$ articulated this crisis as an urgent query facing the English nation referring to it as the "condition of England question.”,53 To represent and to explore this national emergency, Carlyle imagined early Victorian England as a diseased national body. For Carlyle, Chartist politics and other manifestations of working-class discontent were outward signs of an illness ravaging England. There were "symptoms on the surface [which you abolish] to no purpose, if the

\footnotetext{
${ }^{51}$ Cayley, The European Revolutions, 246.

${ }^{52}$ The Northern Star, November 6, 1841.

${ }^{53}$ Thomas Carlyle, Chartism, Second Edition (London: James Fraser, 1840), 2.
} 
disease is left untouched." ${ }^{54}$ Carlyle then qualified this metaphoric pathology of working class insurgency by making a critical distinction between the "chimera" and the "essence" of the disease of unrest, between its legible symptoms and the deeper causes that they signified. ${ }^{55}$ By taking the "essence" of Chartism as his subject, Carlyle created a broad study of the causes, transmission, and potential control of Chartist agitation; agitation he referred to as "poisoning the sources of life." ${ }^{, 56}$ This use of biomedical discourse to represent the national significance of Chartist agitation was not uncommon during this era. He was drawing on a long history of representations of England and Britain as a body politic as well as a discourse of the 'body social' that emerged in early Victorian Britain. His metaphor of the infected national body also echoed the rhetoric of middle- and upper-class panic about literal contagion in the 1830s, such as cholera and typhus, epidemics which were seen to emanate from urban working-class neighborhoods and often associated with Irish immigrants, and which threatened to contaminate England as a whole. In addition, Carlyle redeployed the figuration of revolutionary politics as a disease, a metaphor common in English conservative reaction to the French Revolution several decades earlier.

Yet a careful reading of Carlyle's metaphor of the diseased national body reveals the unmistakable suggestion of infection by foreign contagion; it implies that England's body has suffered exposure to a contaminant which is not intrinsic to the nation's composition. What alien infectious agent has penetrated England's boundaries and, through pollution of the working class, serves as the catalyst for the disease of proletarian disaffection? According to Carlyle, the source of this infection was Ireland. He names

\footnotetext{
${ }^{54}$ Ibid, 120.

${ }^{55}$ Ibid, 119.

${ }^{56}$ Ibid, 152.
} 
Irish immigration into England as "the sorest evil this country has to strive with”, the means of transmission of an infection which adulterates the body politic with workingclass unrest and revolutionary potential. ${ }^{57}$ Carlyle figures the Irish immigrant as "the ready made nucleus of degradation and disorder” who carried to England the misery of Irish poverty and a "National character [that] is degraded." ${ }^{58}$ Carlyle compared the Irish to an invading pestilence and argued that England had "quarantines against pestilence; but there is no pestilence like that; and against it what quarantine is possible?"59

Carlyle's opinions were scathing of the Irish as they settled in the urban centers across England and although his perspectives were not indicative of the larger English society, they were nonetheless beginning to set a tone. He described the moral and physical condition of the Irish in England as "miserable" as the "Irish darken all our towns.” These savages, with their “wild Milesian features, looking false ingenuity, restlessness, unreason, misery and mockery” were to be found all across the nation like an invading disease into the English body. Carlyle stressed that no matter how hard the English fought this scourge the "Milesian is holding out his hat to beg;" a tone that will be taken up a decade later by the popular media in response to the social consequences of the famine. ${ }^{60}$ The Irish were being depicted as a blight on contemporary urban society, swarming into towns and cities with their uncivilized ways and exacerbating the “Condition-of- England Question.”

Not only was this creature a threat to the healthy body, but this "aboriginal savage of Europe” who spoke a "partially intelligible dialect of English" was a threat to the

\footnotetext{
${ }^{57}$ Ibid, 138.

${ }^{58}$ Ibid, 139, 137.

${ }^{59}$ Ibid, 139.

${ }^{60}$ Ibid, 182-183.
} 
working body of England as well. ${ }^{61}$ The Irishman came "in his rags" and was there to undertake "all work that can be done by mere strength of hand and back; for wages that will purchase him potatoes.” According to Carlyle, the "Saxon man if he cannot work on these terms, finds no work. He too may be ignorant; but he has not sunk from decent manhood to squalid apehood.”62 Carlyle's reference to the Irish as primitive man is one of the earliest links between the animal kingdom and the Celt; a link that will become the standard perception for all native populations as the decades wore on. As Irish competition in the labor market seriously undercut English wages, it had an inevitable impact on the scale of English unemployment, poverty, living standards, and discontent. This theme was explored in greater depth in an 1840 analysis of Carlyle’s work Chartism that appeared in the British and Foreign Review. Like Carlyle, the anonymous author believed that the real cause of English labor woes was the "immigration of Irish labourers into the manufacturing districts [that] threatens the physical state of the labouring classes of England with a deplorable revolution.”63 The author reiterated Carlyle’s argument that the Irish were “willing to work for less, and so are paid less, than the English” thus resulting in the “market price of labour becom[ing] permanently lowered." ${ }^{64}$ And like Carlyle, the author firmly believed that Chartism was the "natural result of the bad moral and social conditions under which our population has grown up.”, 65

At the close of his chapter on the English working class, Carlyle stated even more boldly that "Ireland is in chronic atrophy these five centuries; the disease of nobler

\footnotetext{
${ }^{61}$ Ibid, 73-74, 28.

62 Ibid, 28.

63 “Article I. Chartism. By Thomas Carlyle,” British and Foreign Review, 11. 21 (July: 1840): 9.

64 Ibid, 10.

65 Ibid, 14.
} 
England, identified now with that of Ireland, becomes acute, has crises, and will be cured or kill.” ${ }^{66}$ Through the metaphor of disease and the concrete threat to working condition, Carlyle gives the Irish immigrant a central place in his analysis of working class radicalism in England. The immigration of Irish subjects introduced a 'pestilence' which took hold of a national body already weakened by forms of domestic disorder.

Once he established the growing threat of the Irish pestilence spreading across England, he then connects these immigrants to the Chartist movement and provides his analysis to the threat this movement poses to English order. These savages brought a “force of men armed only with rags, ignorance and nakedness” to English shores and their discontent was fuelling English unrest. Carlyle defined Chartism as "the bitter discontent grown fierce and mad, the wrong condition therefore, or the wrong disposition, of the Working Classes of England.” ${ }^{67}$ This passage evoked images of a dog gone mad, thus naturalizing the connections between Chartism and violent insanity. Carlyle’s words put ‘disposition' and ‘condition' together as if both were choices. He repeatedly compared the peasantry to horses or animals used for labor. Arguing that laissez-faire economics didn't make sense to the lower classes, he used the example of horses, let go at the end of the summer season and told by their owners to find work elsewhere because, with all of the new inventions, there is plenty of work. The workers, according to Carlyle, then "gallop distracted along highways all fenced in to the right and to the left: finally under pains of hunger they take to leaping fences; eating foreign property, and - we know the rest."68 His reference to violence as an end result is clear.

\footnotetext{
${ }^{66}$ Carlyle, Chartism, 144.

${ }^{67}$ Ibid, 2.

${ }^{68}$ Ibid, 28.
} 
Further naturalizing the idea of working-class mental weakness, Chartism goes on to ask whether it is "not the condition of the working people that is wrong, but their disposition, their own thoughts, beliefs and feelings that are wrong?”"69 Yet, Chartism never let its reader hear any of these thoughts, beliefs and feelings, because it never quotes from a Chartist document, newspaper, or speech and therefore never really answers the question posed to the reader. The work is devoid of any human presence relying instead on vague generalizations. Carlyle implied that there was a form of mental illness spreading among all working men and women who suggest change through moral and physical force. He argued that when the "thoughts of a people, in the great mass of it, have grown mad, the combined issue of that people's workings will be a madness, an incoherency and ruin!"70 The insinuation that something has infected the people's thoughts encourages the idea of working class contagion - the idea that the working class body can be infected and infect others. And the weak working class body, both physically and mentally, gives way to one working class stereotype that appears throughout the period: the agitator, someone who stirs up strife (where there presumably would be none) and takes advantage of the ignorant working class dupe to promote his own political agenda. If the working class, repeatedly referred to as 'lower class’ by Carlyle, was “the great dumb, deep-buried class... who in his pain, if he will complain of it, has to produce earthquakes” really existed as such a dumb lump, it must therefore naturally be susceptible to these crafty agitators as the masses thus had no will of their own. ${ }^{71}$ Another form of the agitator was the educated working class man, perhaps an auto-didact or member of a Mechanics Institute. Carlyle argued that these men can "prove anything by figures” as he discounted

\footnotetext{
${ }^{69}$ Ibid, 7.

${ }^{70} \mathrm{Ibid}, 7$.

${ }^{71}$ Ibid, 68.
} 
the statistics on poverty and the auto-didacts who used them. They were "a member of some Useful-Knowledge Society” who stopped "your mouth with a figure of arithmetic." ${ }^{, 72}$ Nowhere in the document does he portray Chartists as having a rational complaint or as being an organized, educated movement. Instead, he questions whether the conditions of the working class are really so wrong that "rational working men, cannot, will not, and even should not rest quiet under it... or is the discontent itself mad, like the shape it took?"73 Here anything rebellious is not rational - foreshadowing the document’s later reminder that "the first rebel was Satan." ${ }^{74}$ Carlyle also uses the Girondins of the French Revolution as exemplars of this "Questionable species” who "urge the Lower Classes to rebel," a theme repeated by Punch and other media outlets concerning the continental uprisings in the late $1840 \mathrm{~s}^{75}$

Denying the working class rationale was not the only way Carlyle reflected upon their savageness. Because statistics were not reliable, he attributed their poverty and irrational behavior on the curse of alcohol. Gin, he argued, drew the lower classes into the "black throat" of wretchedness, removing all ability to "think or resolve" as the "liquid Madness" stirred violence and led the lower classes into the "dismal wide-spread glare of Chartism or the like." ${ }^{76}$ Here, he faulted gin for the people’s inability to think or reason and linked the liquor to the mental defects and insanity that must lead them to bad dispositions and conditions. From within the dark space of alcohol, Chartism comes as something 'dismal' and negative. Not only does the passage insinuate working class drinking as being more wide-spread than that of other classes, building the stereotype that

\footnotetext{
${ }^{72}$ Ibid, 11.

${ }^{73}$ Ibid, 7.

${ }^{74}$ Ibid, 72.

${ }^{75}$ Ibid, 71.

${ }^{76}$ Ibid, 29.
} 
the class as a whole is weak, but it also links Chartism to the concept, even the experience of being drunk, weak, and savage; traits that were also directly linked to the Irish immigrants of the urban centers of England.

Chartism was, according to Carlyle, a violent mad animal seething in anger and most importantly, threatening to destroy the social fabric of the nation. Their demand of universal suffrage ushered in, according to Carlyle, a "democracy" that could be nothing more than a "regulated method of rebellion and abrogation.”" ${ }^{77}$ He described Manchester, the center of Chartist activity as "disorganic," stirring ideology that "affects us all with its Chartism.”78 He also carefully positioned Chartism amidst other well-known scenes of violence in his description of “Glasgow Thuggary, Chartist torch-meetings, Birmingham riots, [and] Swing conflagrations."79 This workers’ movement, “with its pikes... speaks through inarticulate language,” and presented a clear danger to the socio-political order of the day. ${ }^{80}$ Chartism was such a powerful threat because, Carlyle stressed, "no man is justified in resisting by word or deed the Authority he lives under." ${ }^{81}$ Reflecting the growing Victorian social norm of restraint he argued that "obedience... is the primary duty of man” and society could only function when "a man has his superiors, a regular hierarchy above him" and it was essential that this order and hierarchy be maintained. ${ }^{82}$ In stressing the need for order and civility in comparison to the mad dog mentality of the Chartists, Carlyle was, in essence, calling into question the movement's intentions and

\footnotetext{
${ }^{77}$ Ibid, 54.

${ }^{78}$ Ibid, 107.

${ }^{79}$ Ibid, 7.

${ }^{80}$ Ibid, 33.

${ }^{81}$ Ibid, 93.

${ }^{82}$ Ibid, 93-94.
} 
the viability of its methods, thus denying its legitimacy within the English socio-political framework.

Carlyle was a very influential writer and thinker during the Victorian Era, but his voice was not the only one on the issue of race and class during this period. With the abolition of slavery in 1807, debate raged in England as to the appropriate use of the dark peoples of the world. Carlyle’s rhetoric on the Irish, as previously argued, strongly mirrored his language on blacks of the West Indies. John Stuart Mill responded to Carlyle's opinions on the dark races with an article titled “The Negro Question,” stealing Carlyle's own words. It was published in 1850 in Fraser's Magazine as a letter to the editor. Mill sets out his own position on the use of African labor and race. He references the "Afrocentric" thesis of antiquity and states that the "original Egyptians are inferred... to have been a negro race” and it was therefore the blacks that taught the Greeks "their first lessons in civilization” ${ }^{83}$ This theory clearly sets blacks and whites on an equal footing, in stark contrast to Carlyle. He believes that "justice and reason shall be the rule of human affairs” no matter where those affairs take place. ${ }^{84}$ Revolution, Mill argues, is not the result of a savage biology, but instead festered "while the lash yet ruled uncontested in the barrack-yard... and while men were still hanged by dozens for stealing to the value of forty shillings." ${ }^{85}$ He argues that England had the "skill to prevent” Irish beggary and did nothing, yet the abuses of slavery were actively encouraged as a means of control and profit. ${ }^{86}$ This perspective provided a sharp contrast to Carlyle’s vitriolic outrage at the inferior races, including the Irish. It serves to illustrate the complexity of

\footnotetext{
${ }^{83}$ John Stuart Mill, “The Negro Question,” Frazer’s Magazine for Town and Country, (February, 1850): 468.

${ }^{84}$ Ibid, 467.

${ }^{85} \mathrm{Ibid}, 465$.

${ }^{86}$ Ibid, 465.
} 
Victorian attitudes and presents a more nuanced rhetoric in the popular press. It was, however, situated within a framework of escalating immigration that made its more balanced approach difficult for the English middle class rate-payers to accept as Chapter Four and Chapter Five will explore.

\section{The Growing Fear of Chartist Violence}

This perception of Chartism as violent and aggressive had its roots in very concrete events and the language of the movement itself, which came, according to Gammage, from the Irish under O’Connor’s stewardship. Gammage viciously condemned John Mitchel's Dublin newspaper, The United Irishman, as a constant source of agitation and hatred toward England under the guise of Chartist reform. ${ }^{87}$ O’Connor lacked judgment and London Chartist leader William Lovett described him as a “malignant influence” who converted the working class Irish "into an instrument for destroying everything intellectual and moral in our movement." ${ }^{88}$ Historian R. Balmforth argued that Chartism’s moral force was “deluded and misled” by O’Connor, a “vain and self-seeking” man who sought only agitation and disruption without any basis in real social reform. ${ }^{89}$ In his memoirs, W.E. Adams clearly recalled O’Connor’s “absolute dominion over the cause” through the “demagogue” Northern Star publication. ${ }^{90}$ The union with the Irish the Chartists once saw as indispensible had quickly become a liability as their perceived role in the growing violence became a fact to the English public.

\footnotetext{
${ }^{87}$ Gammage, The History of the Chartist Movement, 296.

${ }^{88}$ Gammage, The History of the Chartist Movement, 45, William Lovett, The Life and Struggles of William Lovett, 294, 297.

${ }^{89}$ Ramsden Balmford, Some Social and Political Pioneers of the Nineteenth Century (London: G. Allen, 1900), 189.

${ }^{90}$ William Edwin Adams, Memoirs of a Social Atom (London: Hutchinson \& Co, 1903), 203-205.
} 
This fear of the disruption of the social order was a prominent theme among middle class Victorians. Society had its order, structure and hierarchies and law and government were institutions to be respected. ${ }^{91}$ Moderation and restraint were quickly becoming crucial facets of the era as reflected in the growing number of books on etiquette and the shifting definition of masculinity. ${ }^{92}$ Advice literature such as the Female Instructor warned that children "must be instructed to regulate their senses, their imagination, their appetites, and their passions. ${ }^{, 93}$ Children also needed to be shown "how unreasonable and unmanly a thing it is to take fire at every little provocation." ${ }^{94} \mathrm{~A}$ reserved nature and control over one's emotions were the mark of a civilized English citizen in Victorian England. Passion was "so injurious to society, and so odious in itself... that one would think shame alone” could prevent a person from exhibiting it. ${ }^{95}$ Cardinal John Henry Newman, in his 1852 analysis of the modern university, stated that a gentleman was one who "avoids whatever may cause a jar or a jolt in the minds of those with whom he is cast." ${ }^{96}$ Civilized Man did not offend, upset, or disrupt the social order for any reason whatsoever. Control over emotions, or conversely, the lack thereof, served as a moral barometer for Victorian England and this control eventually had larger social and political implications as a reflection of class and character. It was this concept of

\footnotetext{
${ }^{91}$ F. David Peat, From Certainty to Uncertainty: The Story of Science and Ideas in the Twentieth Century (New York: Joseph Henry Press, 2002), 103.

${ }^{92}$ For more on this theme see: Joel Faflak and Julia M. Wright, Nervous Reactions: Victorian Recollections of Romanticism (New York: SUNY Press, 2004); John Tosh, A Man's Place: Masculinity and the MiddleClass Home in Victorian England (Yale University Press, 2004); Manliness and Masculinity in Nineteenth Century Britain: Essays on Gender Family and Empire ed. John Tosh (New York: Pearson Longman, 2005); Herbert Schlossberg, The Silent Revolution and the Making of Victorian England (Ohio: Ohio State University Press, 2000).

${ }^{93}$ The Female Instructor (London: H. Fisher, Son, and P. Jackson, 1836), 18.

${ }^{94}$ Ibid, 22.

${ }^{95}$ Ibid, 135.

${ }^{96}$ John Henry Newman, The Idea of A University, Reprint (London: Longman’s, Green and Co. 1891), 101.
} 
character that set the moral tone for social policy, particularly in regard to poverty and destitution as the decades progressed.

As Chartism grew in strength and political significance, the language and methodology became more aggressive, thus conflicting with this growing concern for moderation and restraint of behavior. In 1848, George Jacob Holyoake, a staunch supporter of Chartism and a labor activist, published a lengthy essay outlining his views on the movement and what he believed were "hindrances to the progress" of that cause. Because of these 'hindrances,' such as a lack of recognition from established political structures, he stressed that Chartism needed to become "an AGITATION rather than a MOVEMENT.”97 Chartist sympathizer and publisher William Shirrefs told the public that there was a "great conflict coming" and he believed that the poor needed to "furnish their contingent of combatants.” While he did stress that the battle was not of "arms, but of principles,” the imagery depicted a violent clash much like those described by the novelists of the time. ${ }^{98}$ Much of this violence centered around the northern faction of the Chartist Movement under Feargus O’Connor, thus linking it inextricably with the Irish in those same northern industrial centers.

\section{Violence in the Streets}

While the Chartist language conjured images of a violent, aggressive movement, the realities of the working class struggle did nothing to alleviate middle class fears and the uprisings served to indelibly link the Irish with this violence. Shortly after the publication of Carlyle’s Chartism, a series of violent riots erupted across Great Britain that had a profound effect on the image of the workers' movement and the immigrant

\footnotetext{
${ }^{97}$ George Jacob Holyoake, “Our Principles and Course of Action,” Cause of the People, May 20, 1848.

${ }^{98}$ William Shirrefs, “Whom Shall We Trust,” People’s Press, May 181848.
} 
Irish population as a whole. The April mass meeting in Kennington Common, held in 1848 just after the Paris revolution, became a gathering of chaos, a clear indication of the subversive nature of Chartism. ${ }^{99}$ Reports of the event were damning, portraying the movement as criminal, unconstitutional, un-English, and distinctly Irish in makeup. That morning, The Times published a warning to its readers, declaring the entire Chartist movement was a "ramification of the Irish conspiracy." 100 The rebels, according to the report, wanted to make "as a great a hell of this island as they have made of their own.”101 Catholics had a habit of "congregating together for vague and undefined reasons" and these gatherings were taking on a violent, disruptive edge. ${ }^{102}$ The people were united against these violent insurgents, and stood firmly on the side of law, order, and Englishness. ${ }^{103}$ In the wake of the uprisings, other publications continued to directly associate the Irish with the Chartist platform and violence. Punch ran an article entitled “Song of the Seditionist” which portrayed Chartism transmogrified into Irish rapine, pillage, and massacre. ${ }^{104}$ In July of 1848, The Times was appalled by “extravagance of wild sedition which, for want of any other adjective, must be denominated Irish,” and London, it warned, was endangered by the "Irish love of knife, dagger and poison bowl.” ${ }^{05}$ That same year Punch stressed that while the English Chartists were perhaps

\footnotetext{
${ }^{99}$ Margot Finn, After Chartism: Class and Nation in English Radical Politics 1848-1874 (Cambridge: Cambridge University Press, 2004), 63. Also see: Peter Scheckner, An Anthology of Chartist Poetry: Poetry of the British Working Class, 1830s-1850s (Fairleigh Dickinson University Press, 1989); Trygve R. Tholfsen, Working Class Radicalism in Mid-Victorian England (New York: Columbia University Press, 1977).

${ }^{100}$ The Times, April 10, 1848.

${ }^{101}$ Ibid.

${ }^{102}$ George Lewis Smith, Ireland: Historical and Statistical (London: Whittaker \& Co., 1849), 62.

${ }^{103}$ W.F. Collier, History of the British Empire (London: T. Nelson and Sons, 1859), 324.

104 "Song of the Seditionist," Punch, xiv (January-June 1848): 240.

105 The Times, July 8, 1848.
} 
misguided, but nonetheless harmless, the Irish faction were violent beasts that needed subdued before their madness spread. ${ }^{106}$

The violence started in the late 1830s and in November of 1839, there was a violent confrontation between the military and workers on the streets of Newport. Factory workers took to the streets and soldiers were sent out to quell the disturbance. Private John Clarke of the $45^{\text {th }}$ Footage Regiment, provided police with testimony of the event and he recounted his exchange with a rioter. He asked an individual about the rationale behind the uprising, and the unnamed person announced to the soldier that "the Charter would be the law of the land,” after a grand display of aggression and force. ${ }^{107}$

In 1840, there was violence in both the industrial town of Sheffield and in the heart of London itself. There was a Chartist gathering in Sheffield and workers marched from the meetings into the streets. Soldiers were sent to break up the disturbances and reported a “considerable body of men... whose spears were distinctly visible” heading toward the center of town. The soldiers were "attacked with pikes and bayonets" and dozens of arrests were made. The military confiscated a "great quantity of muskets, pikes, daggers, cats, powder, balls, [and] grenades" and prisoners "disclosed a plan to fire the town” during the riot. ${ }^{108}$ That same month, just as The Times had predicted in 1838, a Chartist meeting in London was broken up after reports of possible violence. According to witnesses, the main speaker at the meeting, Mr. Spurr, stirred the audience with his aggressive rhetoric stating that the "only way to preserve the peace was to be prepared to wage war” and the audience responded with "loud cheering.” Police entered the premises

\footnotetext{
${ }^{106}$ Punch 14 January-June (London: The Office, 1848), 156.

107 “The Chartist Riots at Newport,” London Examiner, November 17, 1839: 727.

108 “The Chartist Outrages at Sheffield,” London Examiner, January 19, 1840: 41; a cat is a three pronged instrument designed to be tossed on the ground to destroy the hooves of horses.
} 
and searched people at the meeting. According to the police, like the Sheffield Chartists, a "great variety of daggers, knives, sabers, [and] pistols loaded with ball and primed" were found among the audience members. ${ }^{109}$ Both of the news stories were placed side by side in the January $19^{\text {th }}$ edition of the London Examiner to reinforce the violent threat from this growing workers’ movement.

In August of 1842, an even more violent uprising occurred on the streets of Manchester, a Chartist stronghold in the north, and once more the London Examiner gave it prominent coverage. On Sunday, August 7, eight to ten thousand people, largely ironworkers, gathered in Mottram Moor just outside of the city. On Monday, this same crowd split into various factions, traveling from factory to factory to encourage the bulk of the weavers to join the demonstration. On the $9^{\text {th }}$ of August, several thousand workers marched into the town of Manchester. Like Dickens' fictitious riot in his work Barnaby Rudge, the crowd began throwing "stones at the windows of the factories" and according to newspaper accounts, the "immense productive power of the commercial metropolis was utterly idle.” Witnesses described the scene as one of “confusion and dismay” as a “spirit of insubordination spread." ${ }^{110}$ During the riot, the establishments of several prominent businessmen in town were either burned or looted. The police station at Hanley was broken into and papers and record books were destroyed. Prisoners were also released and as the violence escalated, several rioters were killed and many were severely wounded. By Monday, the $16^{\text {th }}$ of August, the unrest had spread and colliers gathered at Shelton to meet with Chartist leaders. The meeting, according to witnesses, was filled with “violent speeches” and immediately afterward, the "work of destruction

\footnotetext{
109 “Arrest of Armed Chartists in London,” Ibid.

110 “Art. VIII. Notes of a Tour in the Manufacturing Districts of Lancashire,” Eclectic Review, 7 (October: 1842): 464-465.
} 
commenced.”"111 The London Examiner, in its coverage of the event, stressed that the actions in the manufacturing district were "evils that threatened to disorganize society." As the violence spread, it would eventually involve the "whole country in one common ruin, and one common downfall.”112 The Examiner looked for a source for the uprising and referencing the Manchester Guardian, they found the riots were "the carrying out of that fiendish scheme developed by Mr. Feargus O’Connor and other agitators," a direct link to the Chartist movement and its prominent Irish leader. ${ }^{113}$

\section{Chartism and the Irish Connection}

This connection was further solidified by writer, publisher, editor and prominent Chartist supporter William Shirrefs. His weekly magazine, The People’s Press, strongly defended the Irish against English oppression. On the $29^{\text {th }}$ of November, 1847, MP Sir George Grey introduced a bill before Parliament for the "prevention of crime and outrage” in Ireland. Shirrefs covered the story in his weekly journal. Grey wanted to enlist the aid of all males from the ages of 16 to 60 in order to apprehend criminals across the island, plus add 200 new constables to the forces present there. Grey believed these measures were vital in order to protect the defenseless landlords from the murderous local population. Grey argued that the landlords were not safe as the natives protected their own and allowed heinous acts to go unpunished. Sir Verner argued before Parliament that the bill was necessary to "give protection to the lives and properties of the industrious and well-disposed persons” in Ireland against those readily committed to

\footnotetext{
${ }^{111}$ Ibid, 465.

112 Ibid, 466.

113 Ibid, 467.
} 
atrocities. ${ }^{114}$ MP Poulett Scrope, who represented the district of Stroud, presented statistical information on the agrarian outrages for 1845 . The constabulary returns indicated that there was hardly a county in Ireland not affected by the growing violence. Scrope reported that in 1845, there were six acts of violence in Antrim, eight in Armagh, 154 in Clare, 72 in Limerick, 74 in Leitrim, and 253 in Tipperary. ${ }^{115}$ Shirrefs responded to this evidence by arguing that one needed to look beyond the act of violence and examine its cause. He stressed that the historians, in writing Irish history, needed to point out that "Anglo-Irish have ever persecuted the native Irish people, holding them as dogs and as slaves." 116 The past was rife with English contempt for the Irish as the "lives of natives chiefs and septs were held cheap" in countless invasions over the centuries. ${ }^{117} \mathrm{He}$ stressed that simply tossing the population a few months of work or a few months of food through the Poor Laws would not "cast [away] the habits, ideas, and customs of centuries.” Because the population did not change rapidly enough to suit English tastes, they were labeled "incorrigible, innately depraved beyond the reach of human power." What England failed to see, according to Shirrefs, was its responsibility in creating the conditions in Ireland. ${ }^{118}$ He continued this support in an article titled "Peace, Law, and Order” that addressed the changing political situation in the English Parliament and its effect on Ireland. Shirreffs argued that the Whigs, who "lifted their humane voices" by ousting Sir Robert Peel over his policies toward Ireland and free trade then turned their backs on these very issues. They had become just as vicious to the Irish people through

\footnotetext{
${ }^{114}$ Sir W. Verner, “Crime and Outrage (Ireland) Bill- Committee,” House of Commons Debate, Vol. 95 (December 10, 1847): 936.

${ }^{115}$ MP Scrope, “Crime and Outrage (Ireland) Bill- Committee,” House of Commons Debate, Vol 95 (December 10, 1847): 945.

116 “Irish Legislation Saturday 1 January 1848,” The People's Press and Monthly Historical Newspaper, William Shirrefs ed., Vol. II, (London: James Watson, 1848), 8

${ }^{117}$ Ibid, 8.

${ }^{118}$ Ibid, 9.
} 
suppression of public opinion in both England and Ireland, through draconian legal measures, and through oppressive taxation for the poor in both nations. England continued, according to Shirrefs, to bear the burden of the crisis in Ireland even with a change in government. ${ }^{119}$ Later that same year, he published an article on the continued violence in Ireland entitled, "Why is Ireland so Rebellious?” and in it he reiterated England's responsibility in the Irish suffering. He pointed out that by the 1600s, Ireland was "the vanquished and England the vanquisher," thus forcing the Irish to rise "against the cruelty and inefficiency of their masters.” This uprising continued into the 1800s, Shirref argued, because Ireland "has groaned under a profligate and absentee proprietary.” The island has suffered from "the confiscation of the land to incompetency and foreign domination, and the persecution of religion” that has led to the "degraded state” of the nation. These conditions, created by England, have forced the Irish population into subjugation, thus driving them to extreme behavior. The continued violence across the island, Shirref argued, can be directly traced back to English actions. $^{120}$

Like Shirref, John Stuart Mill defended Ireland and suggested that brute force as a policy had been a complete failure. Citing Cromwell, he argued that after four and a half centuries of rule, England had only succeeded in making Ireland far worse economically and socially. Ireland was demoralized and disorganized with little "rational industry" to support its people. ${ }^{121}$ He believed that Ireland needed to be an "altered country at home”

\footnotetext{
119 “Peace, Law, and Order,” June 1, 1848," The People's Press and Monthly Historical Newspaper, William Shirrefs ed., Vol. II, (London: James Watson, 1848), 89.

120 "Why is Ireland so Rebellious?” The People's Press and Monthly Historical Newspaper, William Shirrefs ed., Vol. II, (London: James Watson, 1848), 153.

${ }^{121}$ John Stuart Mill, Collected Works of John Stuart Mill (Canada: University of Toronto Press, 1986), lxxxviii.
} 
in order to stem the tide of immigration not only into England, but globally as well. ${ }^{122}$ His answer was government investments in public works. These projects would not only provide employment to large numbers of people, but they would also improve living conditions across the island as well. He was firmly set against the tyranny of landlords and suggested that a shift away from pure agriculture would improve tenant-landlord relations as rents could be paid regularly. This defense, however, was tempered and reflected the zeitgeist of the period. His strong support for the improvement of Ireland was a far cry from Carlyle’s ranting, but like other authors of the era, he nonetheless argued that "it was not well to select as missionaries of civilization a people who, in so great a degree, yet remain to be civilized.”123 The Irish needed a better home country because they were human beings deserving of such, but because they were also an embarrassment to the Empire across the globe.

To the middle class, this defense seemed to come from the close ties between the Chartist cause and the Irish immigrants into the industrial centers. Even supporters such as John Stuart Mill acknowledged their troubling lack of civilization. Chartism was not only threatening the socio-political order of England, but it was stirring Irish troubles as well. Shirref's opinions, while not a reflection on the stance of every Chartist member, added fuel to growing middle class perception of the movement as a whole. His passionate and fervent defense of the Irish gave credence to the belief that this disruptive, unruly movement was inextricably linked to the growing number of Irish immigrants. This link, to the middle class of England, was a wholly negative one.

\footnotetext{
${ }^{122}$ Ibid, lxxxi.
}

${ }^{123}$ Ibid, lxxxi. 


\section{Middle Class Fears Reflected in Literature}

Carlyle's fear of disorder and of mob violence evident in Chartism, whether

fomented by the Irish or the non-Irish, echoed a more generally held fear of the educated middle classes concerning the working class. Popular literature started to reflect this fear of disruption and the working class man, bent on social disorder, became a stock character in novels of the time. More than one author of the period used this character as a symbol of chaos, the decay of morals, and the degradation of English society. Links to both Chartism and the Irish appeared in these works of fiction as well. One of the most direct attacks on Chartism came from writer Elizabeth Gaskell. A traditional middle class woman with a strong religious background, she settled in the Manchester area after she married and the region had a strong influence on her writing. Gaskell's work Mary Barton, published in 1848 at the height of the Chartist campaigns, follows the lives of Mary and John Barton, a family who represented the model English family. In the story, John Barton begins to become disgruntled with his working conditions and turns to the Chartist movement as a possible solution. He returns dejected, however, after participating in the presentation of the first Chartist petition to Parliament. He continues his involvement with the movement in spite of his negative experiences and he begins a downward destructive spiral. Gaskell portrayed the movement as a distraction to and detractor from domestic happiness. The working class devalue the English ideal through their continued desire for a violent social upheaval. It is in this devaluing that John Barton finds his destructive path. He moves from a concerned father and co-worker to an irrational union member, smoking opium and eventually resorting to murder. Gaskell’s work makes a direct connection between Barton's involvement with the Chartist 
movement and his downfall. His only redemption from the fall is through his own death. Through Barton’s actions, such as striking his wife and committing murder, Gaskell makes it clear that strong political feelings cannot co-exist with domesticity, tranquility or Christian love. Gaskell's work was a hierarchy of emotions that demonized anger, and although she attempted to create sympathy for the poor and working class, in reality she presented her middle class readership with a negative violent image of the Chartist movement and working class emancipation.

Another of her novels, North and South, originally appeared as a twenty-two-part weekly serial from September 1854 through January 1855 in the magazine Household Words, edited by Charles Dickens. It too dealt with the striking contrast between the rich and the poor, only in this case the dichotomy was between the northern industrial regions and the wealthier south. Like Mary Barton, the surface story attempts to generate a sympathetic portrayal of the working class struggle through the view of an outsider, Margaret Hale, a socially sensitive lady from the South. However, Gaskell's work creates a divide between the poor and the working class. The Higgins family represents the idealist image of the poor factory worker, struggling to support his family. As individuals, these people are loving, caring, and deserving of sympathy and support. When the working class are portrayed in large groups, demanding emancipation however, Gaskell paints a radically different picture. The factory workers are on strike and when Margaret goes to the factory owner Thornton to ask for his help for the Higgins family, she gets caught in the middle of a violent, tense scene. Mr. Thornton had brought in cheap Irish workers as scabs, and the city is in riot. ${ }^{124}$ When Margaret realizes how close

\footnotetext{
124 This was a common practice in the factories, particularly Manchester. James Taylor, a Manchester silk mill operator, testified before Parliament on his habit of sending out for Irish laborers whenever he had a
} 
the people are to tearing down the doors and the police and army are nowhere to be seen, she encourages Mr. Thornton to go down and appease the people. He does so and she sees that he is in danger. She comes out herself to the people and throws herself on Mr. Thornton to protect him and is hurt by a flying stone. Finally the army shows up and the crowds disperse. This scene depicts the working class rabble as a violent mob to be feared as they gather menacingly against their oppressors. Collectively, they are incapable or rational thought and action, even when faced with a defenseless woman.

This passage also illustrates the growing negative perception of the Irish. As the mill owner, Thornton's livelihood depends upon the continued smooth operation of his factory. The workers represent a violent threat to the peaceful town rhythm, but the Irish represent something even more malicious. While Gaskell can find pity in the lives of the individual workers, such as the Higgins family, the Irish represent the ultimate betrayal. They are willing to break the strike lines. Gaskell sets up a contradictory element in her work. The workers and their cause are portrayed as violent, disruptive and ultimately negative, but those brought in to break the strike are even worse. These are the scabs, incapable of relating to the plight of people like the Higgins family and their struggles. Only the most primitive of the species could be capable of considering only their own survival as the Irish did. Like Carlyle’s perspectives on the Irish, Gaskell's fictitious Irishmen were willing to work for the lowest wages, thus threatening the livelihood of the hard-working English by breaking strike lines.

Famed novelist, publisher, and editor Charles Dickens also addressed the fear of the seething masses in his work Barnaby Rudge: A Tale of the Riots of Eighty, published 
in 1841. The plot is based on the 'no-popery' riots, also known as the Gordon riots, of 1780. Throughout the novel, Dickens explores the lives of the villagers in Epping Forest, just outside London, in the year 1775. He largely focuses on their interpersonal relationships until Chapter 35, with the arrival of Lord George Gordon and his followers. This event interrupts the quiet stability of village life, echoing the destruction that the riots in Gordon's name caused in London itself. The novel concludes with graphic descriptions of the riots themselves, which lasted several days. Using vividly descriptive language, Dickens draws the reader into the frightening quality of the flame-lit faces of the workers as they marched in torch-light processions. These processions become violent as rage and anger ripple through the crowds and riots ensue. Dickens paints a picture of the danger inherent in the presence the working men as they gathered in town. They disturb the stillness and tranquility of the evening with their violent emotions that leads to brute physical force. Instead of a sanitized post-work image, these men wore the faces of the factory and they thrust those faces into the lives of the civilized and restrained general populous. These were faces to be feared because they brought mayhem, social disorder, and violence and reality cemented this in events such as the Welsh miners and iron workers strikes in 1839.

Benjamin Disraeli, the first Earl of Beaconsfield, wrote Sybil in 1845 and it too reflected this growing fear of the radical working class toward violence. Disraeli's work is perhaps the most significant of the published works of the 1840s because he would go on to serve in the government for three decades, as both Prime Minister of the United Kingdom and Chancellor of the Exchequer. His status allowed him to influence the government's position on the Irish and, as a member of the Orange Order, set a tone for 
the nation toward this large immigrant group. In his work Sybil, he attempted to expose the growing discrepancy between the rich and the poor. He argued that there was a double standard between Britain's national success as a world economic power and her exploitation of lower classes. Disraeli thought it possible to make an alliance between masters and workmen which reflected his sympathies with some of the Chartist philosophies in his early career. Like Gaskell, his portrayal of the harsh realities of the industrial towns through the character of Charles Egremont focuses exclusively on the English working class and their struggles through the characters of Walter Gerard and his daughter Sybil. Disraeli uses Gerard to speak eloquently about the harsh factory conditions, low wages, and vicious poverty, but only in relation to the English. While he was working on Sybil, his political views were also changing as the Tory Party was struggling to find direction and leadership and the novel reflects this evolution, particularly as it is applied to the Irish. In his work, the Irish characters are virtually indistinguishable from the English Chartists, yet the distinct influence of their Catholicism pervades the novel. He identifies the group by religion rather than race, and it is this religious influence that begins to corrupt the movement. Disraeli portrays Sybil as an angelic Christian martyr, "a celestial charge” who would "die content if the people were only free” yet there are several acts of violence committed against her by the working class Catholic rabble. ${ }^{125}$ By the end of the novel, Disraeli argues for a union of what he calls England's 'two nations,' but his Chartist characters do not reflect his faith in this movement. Sybil herself gives a fatalistic warning that the gulf between the two nations was "utterly impassible.”" ${ }^{26}$ The masses reflect the pattern of failure evident in

\footnotetext{
${ }^{125}$ Benjamin Disraeli, Sybil (New York: Oxford University Press, 1981), 341, 159.

126 Ibid, 354.
} 
many of the authors of the period. They are unable to create positive change and their actions lead to chaos. Disraeli’s Catholic hordes cannot participate in any meaningful cultural or political activity and he rejects their claim to self-awareness.

The themes of Gaskell, Dickens, and Disraeli’s novels were not singular in the early Victorian period. Consider, for example, the experiences of Alton Locke in Kingsley's Alton Locke, Tailor and Poet (1850); the representation of Slackbridge in Dickens's Hard Times (1854); or the circumstances surrounding the arrest and imprisonment of the central character of George Eliot's Felix Holt (1866). In each of these works, the rabble-rousing image of the working man disrupts the lives of those around them, thus creating dissent and social disorder in his wake. The characters in these novels, like the very real workers across England, were simply waiting for their chance to emerge from the cover of darkness in order to loot, murder, rape and destroy. Class in Victorian England came to denote a relationship of power, and as the novels of the time indicated, even a shared ideology or culture such as Englishness did not override this hierarchy when faced with such violence. The working class were viewed as a collective mass to be feared as a disruptive and potentially violent force. The addition of race simply added another divisive rung to the ladder. The working class could thus be divided even further to create an image of the noble, struggling skilled labor English set against the violent, unskilled labor of the Irish immigrants. In creating these broad stereotypes, the literature served to intensify middle class fears of the Irish working class in particular. Irish migrants were read by both nineteenth century writers and literary critics as incapable of cosmopolitan civilization. For the writers and critics, these people 
were either perceived as simply inferior or so consumed by their struggle for survival they were unable to conform.

\section{Violence and its Source: the Irish}

By 1848, the Irish and the Chartist movement were firmly connected in the eyes of the English public. 1847 and 1848 were also very violent years in Ireland, with several prominent murders and repeated outbreaks of agrarian violence. While these acts were largely associated with the famine, they nonetheless served to strengthen the image of the Irishman as an uncontrollable force of aggression. The government used this image to introduce draconian legislation in order to repress the radical movements. The Crown and Government Security Act was designed to curb the treasonous rhetoric published in Ireland, particularly from the Chartist funded newspaper The United Irishman. The act was, however, used for much more broad applications as well. The criminal distinction between the written word and the spoken word under the act was enormous. Published pieces were classified as a felony, but spoken words were merely a misdemeanor. Under this legal distinction, Chartist newspapers such as the Northern Star could now be targeted as potentially felonious acts. By 1848, The Times believed the Irish were bent on destroyed England as they had Ireland and Parliament made sure the Chartist radicals were not to be a tool for revolutionary hell brewing among the Irish in England. ${ }^{127}$

As the Chartist movement became more prominent as a political force, their reputation as an Irish-driven, violence-based organization grew as well. This fear of disorder, disruption and the potential social chaos that could result became a real fear to the middle class. Inherent in this fear was the connection to the Irish immigrant community through the Chartist movement. The popular media, both newspapers and

${ }^{127}$ The Times, April 10, 1848. 
fiction, began portraying Feargus O’Connor and his fictitious counterparts as thugs disrupting the social veneer of Victorian England. O’Connor's leadership and the early Chartist thrust into the nationalist groups of Ireland drew a line from this threat of disruption directly to the increasing numbers of Irish in the urban centers of the north. This connection became the foundation for a very negative stereotype of the Irishman as an aggressive threat to the social order and laid the groundwork for later hostility. As the Great Famine brought waves of poverty-stricken, illiterate, starving Irishmen into English cities, the early framework of negativity became open hostility as the threat to the social order intensified throughout the 1840s. 


\section{Chapter Three}

\section{The Great Famine}

Throughout the 1840s, the Chartist movement grew in strength and seemed poised to become a powerful socio-political force in England. The middle class feared this development and the threat of violence, closely associated with the Irish, which simmered behind the movement's political front. Had Chartist violence been the only negative perception attributed to the Irish, perhaps the hostility shown toward them in the later century would have been tempered. However, in the midst of the Chartist uprisings, Ireland was hit with massive famines. In 1845, Phytophthora infestans appeared suddenly, afflicting the potato, which was the largest single food source in Ireland, particularly for the rural poor. ${ }^{1}$ Newspapers, magazines and travel journals began to print horrific stories of starvation and deprivation as the potato crop failed year after year. Initially, the English response was mixed, particularly from the government, but overall the public sympathized with the suffering across the seas. As the years wore on and little seemed to change for the better however, attitudes shifted. Observers in England

\footnotetext{
${ }^{1}$ Phytophthora infestans is an oomycete or water mold that causes the potato disease known as late blight or potato blight. The spores of this water mold over-winter on infected tubers, particularly those that are left in the ground after the previous year's harvest, in cull piles, soil or infected volunteer plants and spread rapidly in warm and wet conditions. The early stages of blight are easily missed, and not all plants are affected at once. Symptoms include the appearance of dark blotches on leaf tips and plant stems. White mold will appear under the leaves in humid conditions and the whole plant may quickly collapse. Infected tubers develop grey or dark patches that are reddish brown beneath the skin, and quickly decay to a foulsmelling mush caused by the infestation of secondary soft bacterial rot. Seemingly healthy tubers may rot later when in store. Cited in Paul Koepsell and Jay W. Pscheidt, 1994 Pacific Northwest Plant Disease Control Handbook (Corvallis: Oregon State University Press, 1994), 165. The origin of Phytophthora infestans can be traced to a valley in the highlands of central Mexico. The first recorded instances of the disease were in the United States, in Philadelphia and New York City in early 1843. Winds then spread the spores, and in 1845 it was found from Illinois to Nova Scotia, and from Virginia to Ontario. It crossed the Atlantic Ocean with a shipment of seed potatoes for Belgian farmers in 1845. Cited in John Reader, "The Fungus That Conquered Europe,” New York Times, March 17, 2008.
} 
concluded that the plight of the Irish was due not to circumstance, but to their biological weaknesses as a people.

\section{The Historiography of the Great Famine}

The Great Famine presents historians with a variety of different considerations, including, social, economic, and political perspectives that have become, particularly in recent decades, quite controversial. The first major work on the famine was Canon John O’Rourke's 1874 work titled The History of the Great Irish Famine of 1847. Unlike modern historians, O’Rourke was passionate, angry and vitriolic in his denunciations of the English and their role in the devastating events. As the famine was recent history in his time, his details are accurate and his research thorough, but the emotionally charged sentiment taints the work with a powerful anti-English sentiment bordering on demonization. He rails against England for the senseless deaths of millions of “persecuted innocents” across the tiny island. ${ }^{2}$ He repeatedly references O’Connell by his Irish nickname The Liberator and portrays him as a champion of the downtrodden against the hardened force of the English Parliament.

O’Rourke’s history became the definitive account of the Great Famine until the 1940s, when Eamon de Valera argued that there needed to be a new single volume on the Famine using modern historical theories and techniques. Robert Dudley Edwards from University College Dublin took on the daunting task. He saw the work as a collection of essays from experts across the scholarly spectrum. Over a decade in the making, The Great Irish Famine: Studies in Irish History 1845-52 was finally published in $1957 .{ }^{3}$ The essays attempted to cover the tragedy in depth, but in reality the essays focused largely on

\footnotetext{
${ }^{2}$ Canon John, O’Rourke, A History of the Irish Famine of 1847, reprint (London: Bibliolife, 2008), 218.

${ }^{3}$ The Great Famine: Studies in Irish History 1845-52, ed. Robert Dudley Edwards (London: Brown and Nolan, 1957).
} 
the administrative aspects of the period. The core chapters, for example, examined the English politicians’ perspectives on the growing crisis, the Poor Laws and their administration in Ireland itself, the control over passenger movements in relation to immigration, and the medical administration across the island. Many of the historians focused on the Parliamentary debates of the era rather than the more challenging local sources such as diaries, ship manifests and local newspapers. The overall tone was clearly a direct response to O’Rourke’s emotional outburst in 1874 as the essays were analytical, devoid of anecdotal references and left many unanswered questions.

Work on the famine throughout the 1960s and 1970s tapered off as the 'The Troubles’ began to take center stage in Irish historical thought. The Great Famine became a bit of a void in the long and troubled history of the tiny island. Irish historians were often chastised for their reticence as American and British scholars usurped the subject. Patrick O’Sullivan went so far as to claim that there was a world-wide conspiracy among scholars to ignore the Irish Famine. ${ }^{4}$ While clearly a gross exaggeration, the famine has been a difficult subject for Irish scholars. As IRA activities escalated in the mid-1970s, there were very real fears among the Irish academic community concerning their analysis of the Famine. An examination of the Famine critical of the role of the British government could serve to fuel the growing sectarian violence. One the other hand, any analysis straying from anti-English perspective was labeled revisionist history that only served to insult and betray the memory of those who suffered and died. As late as 1995, Irish historian Christine Kinealy argued that "suffering, emotion and the sense of catastrophe, have been removed from revisionist interpretations of the Famine with

\footnotetext{
${ }^{4}$ Patrick O'Sullivan, The Irish World Wide: History, Heritage, Identity: Volume 6 The Meaning of the Famine (London: Leicester University Press, 1997), 1.
} 
clinical precision. The obscenity and degradation of starvation and Famine have been marginalized." ${ }^{5}$ Those historians who then attempted to return the pain and suffering to the narrative were accused of sensationalism and 'famine-pornography. ${ }^{6}$ Historian Austin Bourke acknowledged that for the Irish, "even after the lapse of more than a century, to discuss the famine years with unemotional objectivity” was a monumental struggle, but he stressed that "an effort should be made” in the name of scholarship. ${ }^{7}$ The famine was a divisive issue even during its time when future Home Rule leader Isaac Butt pointed out that any show of support for the existence of a "formidable potato blight... was as sure a method of being branded as a radical, as to propose to destroy the Church.”8 Over 150 years later and in spite of the decline of sectarian violence, the binary labels of revisionist or traditional nationalist clings to the Great Famine. Historian James S. Donnelly Jr. points out the pendulum is currently swinging farther and farther into the nationalist camp and older schools of thought suggesting that the famine was not the only historical event to shape modern Ireland, such as the work of Raymond Crotty and Roy Foster, are much maligned. ${ }^{9}$

Modern analysis of the Famine therefore, centers on the exclusive role it had in defining what Ireland would become in the later half of the 1800s and into the twentieth century. Debate still remains, however, on the exact role of the English government in the

\footnotetext{
${ }^{5}$ Christine Kinealy, "Beyond Revisionism: Reassessing the Great Irish Famine,” History Ireland, 3/4 (Winter, 1995), 34; See also Christine Kinealy, This Great Calamity: The Irish Famine, 1845-52 (Dublin, 1994).

${ }^{6}$ Donald Harman Akenson, “A Midrash on Galut, Exile and Diaspora Rhetoric,” The Hungry Stream: Essays on Emigration and Famine, ed. E. Margaret Crawford (Belfast: Queen's University Belfast, 1997), 5.

${ }^{7}$ Austin Bourke, The Visitation of God? The Potato and the Great Irish Famine (Dublin, Lilliput Press, 1993), 178.

${ }^{8}$ Isaac Butt, “The Famine in the Land. What Has Been Done, And What Is To Be Done,” Dublin University Magazine, 29/ 172 (April, 1847): 502.

${ }^{9}$ James S. Donnelly Jr, "The Construction of the Memory of the Famine in Ireland and the Irish Diaspora, 1850-1900,” Éire-Ireland, 31 (Spring/ Summer 1996): 26.
} 
disaster. Cecil Woodham-Smith’s 1962 work directly challenged the idea that there was a nation-wide conspiracy to destroy Ireland that developed in the English Parliament. As a Welsh native, she was not swayed by the growing politization of the famine. She argued that the devastation of the nation was because "the government of Lord John Russell was afflicted with an extraordinary inability to foresee consequences." ${ }^{10}$ This was not because he was a genocidal maniac, but a callous English politician. In support of this claim, Woodham-Smith points out the same vicious behavior just a few short years later during the Crimean War. English soldiers, fighting for the crown, were treated with the same parsimony and disregarded as easily as the Irish during the famine. ${ }^{11}$ Although Woodham-Smith's work deviated from the hard-line nationalist stance of deliberate annihilation, she nonetheless set the blame squarely with the English Parliament. While her work is still considered a significant contribution to the historiography on the famine, it has been heavily criticized in recent years for its lack of nuance and judgments concerning the political landscape of the famine era that have now come under greater scrutiny. Russell and Trevelyan are the clear villains and the Irish the clear victims in her story of good and evil that in recent years has become far more complex and nuanced a tale.

In 1983, Joel Mokyr, professor of Economics and History at Northwestern University, published a purely quantitative analysis of the Irish economy from 1800 through 1850, thus indirectly addressing the conditions that led to the devastation of the famine. He was a foreigner and thus outside the political hotbed fermenting around the

\footnotetext{
${ }^{10}$ Cecil Woodham-Smith, The Great Hunger, 1845-9 (London: Hamish Hamilton, 1962), 410.

${ }^{11}$ Ibid, 407. For a more controversial argument centering on the Christian morality of the English political landscape see Peter Gray, Famine, Land and Politics: British Government and Irish Society, 1843-50 (Dublin, 1999).
} 
IRA, the famine, and the Troubles. The primary question he addresses is Ireland's poverty as a case-study in economic underdevelopment. Why was Ireland poor? He argues that the poverty was not limited to the western regions as some historians have stressed, but was instead an ingrained facet of Irish life across the entire island. He focuses a substantial portion of his research on the food supplies and distribution of those supplies in the decades prior to the famine. He contrasts the rural, agrarian lifestyle with that of the industrial center of Belfast with its linen industry, and he argues that the rural regions were slowly shut out of the food distribution as the century wore on. Much of it was exported, and the rural communities had no means of earning a substantial living to purchase the crops like the factory workers did. ${ }^{12}$ As the land became subdivided due to inheritance laws and the population continued to increase, Mokyr argues that the Malthusian model of famine became the framework for the tragedy that ensued. ${ }^{13}$ His work is highly detailed, from the examination of birth rates to the sale and distribution of fertilizer as an economic indicator for troubled small farms. ${ }^{14}$ Mokyr posits that Ireland was poor, not because of the Act of Union, but simply that integration after the passage of the act did not go far enough. Ireland's economy remained on the fringe of the empire and while the free-trade zone created a somewhat integrated economy, it did not create a single nation. England never took the necessary steps to shape Ireland's economy in its own image, and industrialization never crossed the Irish Sea. Ireland did not have the

\footnotetext{
${ }^{12}$ Joel Mokyr, Why Ireland Starved: A Quantitative and Analytical History of the Irish Economy, 18001850 (London: George Allen and Unwin, 1983), 14, 21.

${ }^{13}$ Ibid, 51.

${ }^{14}$ Ibid, 163.
} 
resources to withstand an extended crisis, and when famine repeatedly struck the island, it sank as it inevitably would. ${ }^{15}$

In 1986, Mary Daly’s work The Famine in Ireland was first published and represents one of the first more moderate responses to the challenge of famine historiography. Her analysis is more balanced than that of prior decades and she is careful to avoid heaping abuse and blame exclusively on the English administration of the time. She argues that the potato famine had "neither been foreseen, nor could it have been readily prevented by the English government. ${ }^{16}$ Unlike the major government sponsored work of 1957, she includes the more intimate, emotional stories of death while trying to avoid the nationalist perception of the Irish as the perennial victim. She includes an analysis of the coffin ships filled with the dead as they reached foreign shores without getting maudlin. Her points are thoroughly supported by statistics on death rates at sea, the types of ships and passenger manifests. Although she never descends into the ranting as seen in O’Rourke’s work, she effectively manages to walk the delicate tightrope between the revisionists and the nationalists in order to present a complex picture of the famine as an epochal moment in Irish history.

During the 1990s, in the vein of Mokyr's earlier work the prior decade, historians began to take a Malthusian approach to famine, most notably in Cormac Ó Gráda’s work Ireland Before and After the Famine: Explorations in Economic History, 1800-1925. In examining the famine exclusively from an economic viewpoint, Malthusian historians have been able to excise the emotion from the event while avoiding the revisionist assault. Using Malthus’ analysis on the conditions for famine as a framework, Ó Gráda

\footnotetext{
${ }^{15}$ Ibid, 291.

${ }^{16}$ Mary Daly, The Famine in Ireland (Dublin: Dundalgan Press, 1986), 85.
} 
breaks down Ireland's economic situation just prior, during and after the famine. He compares fertility rates, agricultural and regional growth (or lack thereof), emigration and the role of inheritance for the decades before, during and after the hardest hit decades. He argues that Ireland, both internally and through poor English business practices, had created an untenable economic situation thus making famine a foregone conclusion. Agriculture had stagnated in the early decades as population growth escalated. Regional growth was erratic and Ireland suffered from a lack of any serious industrial base.

According to Ó Gráda, add one disastrous element, such as repeated and widespread crop failure, and mass starvation would inevitably ensue. His analysis is purely economic, and like Mokyr, he relies heavily on formulas, statistics and numerical evaluations in order to establish and prove his claim of inevitably. The famine, according to Ó Gráda, was not the exclusive result of Whig policy nor was it a genocidal plan of the English government with the full support of the people. It was instead a tragic ecological accident intensified by poor government response in England and a desperately fractured economy in Ireland itself. $^{17}$

The 1990s also saw a surge in local famine analysis and microhistories in order to get a more focused picture of the devastation across Ireland and much of this work remains wedded to the nationalist interpretation of the Great Famine and its singularity in determining Ireland's future. Gerald Mac Atasney examines the impact of the famine on Lurgan and Portadown in County Ulster in order to determine how the linen trade in that region affected the starvation and he concluded that Ulster weathered the storm better

\footnotetext{
${ }^{17}$ Cormac Ó Gráda, Ireland Before and After the Famine: Explorations in Economic History, 1800-1925 (Manchester: University of Manchester Press, 1988); Also see his work Ireland: A New Economic History, 1780-1939 (Oxford: Oxford University Press, 1994) for further analysis of the economic conditions leading up to and after the famine period.
} 
than other areas of the island because of their industry. ${ }^{18}$ Anna Kinsella's work focuses on County Wexford during the hardest hit period, 1845 through 1849, using the term holocaust in an attempt to define the number of dead. ${ }^{19}$ Her work is controversial because of this term. It hearkens back to earlier historical trends that portray English policy as a systematic and calculated extermination of the Irish. This trend is outdated in modern Irish historical thought. There has been extensive work on the Skibbereen area, one of the hardest hit regions of the early famine years, most notably Patrick Hickey’s essay describing the famine in that region as a "Rwanda-like scene of bodies floating down the Ilen River,” linking the famine deaths to the modern notion of ethnic cleansing. ${ }^{20}$ Like Kinsella, this is a return to the politically charged language of earlier scholarship that positions the Famine as systematic genocide. David Fitzpatrick and Robert James Scally have both produced microhistories based on letters sent between emigrants and their families as they travelled. Both works provide deeply personal and intimate accounts of the hardships of immigration and the lives of those who remained behind. ${ }^{21}$ F. Finnegan, in his work Poverty and Prejudice: a Study of Irish Immigrants in York, 1840-1875 and L. H. Lees, in his work Exiles of Erin: Irish migrants to Victorian London both provide a microhistory of the Irish once they settled into the growing Irish communities in England. $^{22}$

\footnotetext{
${ }^{18}$ Gerald Mac Atasney, This Dreadful Visitation: The Famine in Lurgan/ Portadown (Belfast: Beyond the Pale, 1997).

${ }^{19}$ Anna Kinsella, County Wexford in the Famine Years 1845-1849 (Ireland: Duffry Press, 1995), 40.

${ }^{20}$ Patrick Hickey, “The Famine in the Skibbereen Union (1845-51)," The Great Irish Famine, ed. Cathal Póirtéir (Dublin: Mercier Press, 1995), 194.

${ }^{21}$ David Fitzpatrick, Oceans of Consolation: Personal Accounts of Migration to Australia (Australia: Melbourne University Press , 1995); Robert James Scally, The End of the Hidden Ireland: Rebellion, Famine, and Emigration (Oxford: Oxford University Press, 1996).

${ }^{22}$ F. Finnegan, Poverty and Prejudice: a Study of Irish Immigrants in York, 1840-1875 (Cork: University of Cork Press, 1982); Lyn. H. Lees, Exiles of Erin: Irish migrants to Victorian London (Manchester:

University of Manchester Press, 1979). Also see: W.J. Lowe, The Irish in Mid-Victorian Lancashire: the
} 


\section{The Famine in Context}

This body of work has been essential in re-introducing the famine to the larger historical landscape not only of Ireland, but also that of the British Empire as a whole. The Great Famine was not a single event, but one in a chain of events throughout the 1800s. Ireland was not an independent nation, but was technically an integral part of the greater United Kingdom, thus providing a powerful link to England during this catastrophic decade. The Irish were, in theory, subjects of the crown in much the same way as their neighbors across the sea. In reality, however, this was hardly the case. As death and devastation swept the island, English attitudes shifted and their paternalistic manner turned distinctly hostile. Why did the famine produce such a change? What caused the English to turn against their brethren instead of continuing to send aid and support? What events, in both England and Ireland, were occurring in addition to the starvation that helped shape public opinion? While historians have addressed these questions, it is necessary to place the Great Famine within the tumultuous period from the 1820s through the 1860s in order to analyze the slow evolution of the English middle class’ changing viewpoints. Irish historians often view the Great Famine as the cornerstone of Irish history during the 1800 s as it was such a cataclysmic event. Something of this magnitude couldn't fail to have repercussions, particularly for England as Ireland's nearest neighbor. What impact did it have on specifically on England as the massive waves of immigration began? What were the long term consequences of those Irish now in England? By placing it within the span of decades both before and after the 
famine, its role in the development of the Irish identity as defined by the English middle class is more clearly highlighted.

\section{The Onset of the Blight}

Before the introduction of potatoes, surveyor William Tighe noted that the Irish poor "frequently sowed beans and esculent vegetables, and had little plots somewhat like a small kitchen garden,” but that changed as a number of potato varieties spread across the island. ${ }^{23}$ The potato crop had become the staple of the Irish diet over the early decades of the 1800s, and by 1845 just under one-third of the farm acreage in Ireland was planted with the crop with three million people largely dependent on it for their survival. ${ }^{24}$ From 1845 to 1855 , the blight ravaged the crop repeatedly, thus wreaking havoc across the country. There had been many partial and even total failures of the potato harvest in the past, caused by inclement weather or various plant diseases, but consecutive annual failures were rare. Although these failures had often made the poor's already desperate situation worse, extreme hardship was a way of life for Ireland's rural poor. Generations had survived and continued to struggle to farm their small plots of land with the same staple crop year after year. The failures of the mid-nineteenth century were, however, not the same as those of the past. Father Theobald Mathew, a prominent temperance crusader active in Ireland, gave testament to the speed at which the blight moved throughout the island. On a journey from Cork to Dublin in July, 1846, Father Mathew observed that the potato "bloomed in all the luxuriance of an abundant harvest,"

\footnotetext{
${ }^{23}$ William Tighe, Statistical Survey of County Kilkenny (Dublin, 1802), 479-480.

${ }^{24}$ Ó Gráda, Ireland Before and After the Famine, 12.
} 
but on his return journey only one week later, he "beheld with sorrow one wide waste of putrefying vegetation.”25

In the first year of the blight, although suffering was widespread, few actually starved, but the blight ebbed and flowed over the country for an entire decade. The poor sold off what little of value they had that first year, leaving little money for rent. Their survival rested upon a successful harvest in 1846, but that year produced only twenty percent of the pre-famine level and this time the blight struck across the entire island. One demoralized farmer from Sligo lamented that "the potato crop is quite done away all over Ireland... there is nothing expected here only an immediate famine.” ${ }^{26}$ Next to 1846, 1848 was the worst year, but the harvests continued to be affected straight through until 1855. The harvests during that ten year period consistently generated less that fifty percent of the 1844 level. $^{27}$

Images of suffering permeated the English press as news of the famine spread across the world. Mrs. Asenath Nicholson, an American school teacher and writer, travelled to Ireland twice to personally investigate the plight of the poor and she published two volumes detailing her experiences. She was clearly sympathetic to the Irish plight. The socio-political goal of her writing was to not only raise awareness about the conditions, but to chastise the English government for its lack of adequate response to the crisis. Her first trip, in 1844 and 1845, was during the first massive crop failure. Upon her arrival in Dublin, she described scenes of “squalid poverty in every street," poverty that

\footnotetext{
${ }^{25}$ John Francis Maguire, "Letter to Sir Charles Trevelyan, Secretary of the Treasury," in Father Mathew: A Biography (London: Spottiswoode and Co., 1865), 234.

${ }^{26}$ Cited in Kerby A. Miller, Emigrants and Exiles: Ireland and the Irish Exodus to North America (Oxford: Oxford University Press, 1988), 282.

${ }^{27}$ C. Woodham Smith, The Great Hunger (London, 1962), 91.
} 
haunted her trip across the island. ${ }^{28}$ After leaving Dublin, she took a coach into the countryside and at the first town on the coach's stop she reported that upwards of 220 beggars appeared like "swarming bees" and filled the town square to capacity with their hands out. ${ }^{29}$ This scene repeated itself on every occasion that the coach stopped and she finally admitted that she began to "dread the appearance of a human creature” each time they pulled into a new town because of the constant misery of the "hunger-armed assailants." 30 Their living conditions were squalid and she saw many "lie down in floorless cabins, with little prospect of better days" and she lamented that it was "hard for mothers to see their children die” as she witnessed funeral processions in all corners of the country. ${ }^{31}$ While the Irish poor had her pity, Mrs. Nicholson unleashed her anger on the upper classes. Early in her travels on the first trip, she described a dining experience with Anglo-Irish and English aristocrats who were "professed enemies" of the native population, “[c]alling them a company of low, vulgar, lazy wretches” who, according to the elite, "prefer beggary to work, and filth to cleanliness." 32 Like the charges of neglect toward the English during the famines of the 1820s, Mrs. Nicholson argued that little had changed in the attitudes of the rich. ${ }^{33}$ They not only ignored the misery of the Irish, but they blamed the people themselves for its continuation. Her benevolence reflects a

\footnotetext{
${ }^{28}$ Mrs. Asenath Nicholson, Ireland's Welcome to the Stranger. Or An Excursion through Ireland in 1844, 1845, for the Purpose of Personally Investigating the Conditions of the Poor (New York: Baker and Scriber, 1847), 35.

29 Ibid, 45.

30 Ibid, 47, 49.

${ }^{31}$ Ibid, 96, 155.

32 Ibid, 40.

${ }^{33}$ For more detailed accounts of the famines in the 1820 s see W. Weatherston, "Famine In Ireland!,” Black Dwarf , 9:8 (21 August, 1822): 286-288; "Inadequacies of the Subscription for the Relief of the Famine in Ireland,” Black Dwarf, 8:23 (June 5, 1822): 793-803; “Irish Insurrection Bill,” House of Commons Debate, Volume 7, (July 8, 1822): 1522-1547.
} 
sympathy with and kindness toward the suffering of the Irish rather than outright hostility or indifference.

The early years of the Famine hit certain regions far harder than others as other accounts reinforced Mrs. Nicolson’s depictions. Reverend Edward Marcus Dill, who was on missionary work throughout Ireland, described the "[a]ir of desolation... especially in Munster and Connaught” as he traveled across the country. He repeatedly encountered “half-decayed” towns devoid of life. Rows of once healthy men stood in long lines, their bones protruding and skin sagging, waiting for meager charity handouts. Entire families were often found “dead in their cabins together.” These scenes eventually became the norm throughout Ireland as the blight spread. ${ }^{34}$

\section{The Ravages of Hunger}

Accounts of the later years of the Famine intensified the horrific images of death, disease, and malnutrition. By this time, there had been repeated years of crop failure and Ireland was in a full-blown crisis. Mrs. Nicholson, on her second trip to the country, recounted stories of families eating parts of dogs in their stews. One family went for two days without food before they resorted to eating their pet. ${ }^{35}$ Like her prior trip, skeletal beggars swarmed the streets and "starving men struggling along the side of the road," sick with fever and dressed in rags were omnipresent. ${ }^{36}$ As she travelled into the rural areas on charity calls, she found "a girl of two years dying on a litter of straw... nestled by the emaciated father." 37 She recounted a moment of horror when she "gave a little boy

\footnotetext{
${ }^{34}$ Rev. Edward Marcus Dill, The Mystery Solved: or Ireland's Miseries; The Grand Cause, and the Cure (Edinburgh: Johnstone and Hunter, 1852), 9, 10.

${ }^{35}$ Mrs. Asenath Nicholson, Annals from the Famine in Ireland In 1847, 1848, and 1849 (New York: E. French, 1851), 34.

${ }^{36}$ Ibid, 37.

${ }^{37}$ Ibid, 66.
} 
a biscuit" but she realized it could not save him. She recalled how he "took it between his bony hands, clasped it tight... and gave a laughing grin that was truly horrible.” 38 She compared the Irish condition with that of American slavery and said, "Never had I seen slaves so degraded... these poor creatures are in as virtual bondage to their landlords and superiors as is possible for mind and body to be.”39

Rev. Theobald Mathew also wrote extensive reports on the conditions in Ireland and like Mrs. Nicholson, he witnessed first hand the growing crisis. As the crops failed year after year, migrant workers could no longer find employment being "pretty nearly Half a year partly idle.” 40 He described scenes of “extreme Destitution” as the local population was “deprived of their own Means of Subsistence.” These reports echoed the working conditions of a decade prior, when in 1830 Pierce Mahoney, Esq., testified before Parliament that the average laborer was "employed for the day" during harvest and if it rained before half a day of work commenced, "he is dismissed and gets nothing," and owing to the weather conditions in Ireland, this was not uncommon. ${ }^{41}$ The famine of the 1840s was so pervasive that the rural poor, starving and desperate, flocked to the urban areas, thus creating overcrowded conditions and heightening the risk of disease. Rev. Mathew wrote of the "living Tide of Misery" flooding into the city of Cork. An estimated 20,000 people, “Panic-struck,” jammed into the limited lodging-houses of the urban center. $^{42}$ Although some found shelter, Rev. Mathew said most were "houseless and without Lodgings” and succumbed to a variety of diseases. In 1846, some 6,000 people

\footnotetext{
${ }^{38}$ Ibid, 103.

${ }^{39}$ Ibid, 143.

${ }^{40}$ Rev. Theobald Mathew, Correspondence From July, 1846, to January, 1847, Relating to the Measures adopted for the Relief of the Distress in Ireland. Board of Works Series (London: William Clowes and Sons, 1847), 241.

${ }^{41}$ Pierce Mahoney, First report of Evidence from The Select Committee on the State of the Poor in Ireland. Minutes of Evidence: 24 March-14 May, 589:II (June 30, 1830): 6.

${ }^{42}$ Mathew, Correspondence From July, 1846, to January, 1847, 242.
} 
died in the city of Cork, almost all of them the "rural poor" who had flocked to the safety of the city. ${ }^{43}$ The urban population, overwhelmed by the sheer number of poor, reacted by driving them from the town to find relief elsewhere. As they straggled from the city, most wandered aimlessly until "Death puts an end to their Misery." 44 Captain Wynne, a military officer stationed in Ireland, witnessed the "intensity of suffering” as the natives “scattered over the turnip fields, like a flock of famishing crows,” scavenging for anything of sustenance. He told of "mothers half-naked, shivering in the snow and sleet... children... screaming with hunger” as the blight continued to spread. ${ }^{45}$

\section{Inadequate Relief}

As the people in Ireland attempted to cope with the extent of the Famine, voluntary organizations and societies, like the Quakers, organized relief and established soup kitchens because as Mrs. Nicholson criticized, the “comfortable classes” of AngloIrish "left charity to various societies” because they had "never troubled themselves by looking into the real home wants of the suffering." ${ }^{46}$ Rev. Mathew cited the Society of Friends which was a critical factor in providing relief to the poor of Cork as a specific example of their efforts. They set up seven soup kitchens that fed between three and four thousand a day, but were so limited in their resources that they could often only provide one slice of bread per person. ${ }^{47}$ The Quakers also provided blankets and clothing donated from places as far away as New York City in the United States. ${ }^{48}$ Other volunteers

\footnotetext{
${ }^{43}$ Ibid, 243.

${ }^{44}$ Ibid, 245.

${ }^{45}$ Captain Wynne, Correspondence From July, 1846, to January, 1847, 435.

${ }^{46}$ Nicholson, Annals from the Famine in Ireland, 51.

${ }^{47}$ Mathew, Correspondence From July, 1846, to January, 1847, 245 and Nicholson, Annals from the Famine in Ireland, 44.

${ }^{48}$ Nicholson, Annals from the Famine in Ireland In 1847, 1848, and 1849, 22.
} 
gathered accurate information about the state of the Irish to inform the British and the rest of the world. ${ }^{49}$

Medical services in Ireland struggled with the great number of sick and dying as a host of diseases struck the weakened population. Earlier epidemics had occurred, but the magnitude of cases in the 1840s overwhelmed the facilities with their inadequate accommodations. The sick overcrowded the hospitals, and patients could not get help. The death rate of doctors climbed rapidly because of their work with fever-ridded patients. ${ }^{50}$ One common type of 'famine-fever' was typhus. Another less fatal fever was known as relapsing fever or 'yellow fever.' Other symptoms and diseases that plagued the population included dysentery, diarrhea, measles, tuberculosis, scurvy, and edema. The total death toll from 1841 through 1851 was 1,361,051 people. Fever claimed 222,029, cholera 35,989, dysentery and diarrhea 134,555 and 21,770 died of starvation. Officials compiling the figures noted the numbers very likely did not reflect completely accurate figures and were only gathered from recorded data. At times deaths went unreported because of the vast number of losses or the actual cause of death was misreported. ${ }^{51}$

As the famine deepened across the nation, more and more travelers reported the dreadful scenes of poverty, starvation, and death they witnessed. Lord Dufferin, a prominent English citizen, travelled to Ireland in 1847 and published his memoirs of the experience. He vividly described the vast number of “gaunt, sickly men” doing nothing

\footnotetext{
${ }^{49}$ Dill, The Mystery Solved, 341.

${ }^{50}$ Ibid, 342.

${ }^{51}$ Thom's Statistics of Great Britain and Ireland (Dublin: Alexander Thorn, 1868), 87.
} 
but "languidly hammering stones by the way-side."52 According to his account, diseases such as typhus, dysentery and "a disease hitherto unknown," were sweeping through the population. Hospitals were filled with dead bodies that were "putrifying in the midst of the sick remnant of their families” and the rats and decay made it difficult to recognize that “they had been human beings.” Cemeteries were overflowing, and “remains were hurriedly consigned to the earth without a coffin," or stacked in pits "without offices of religion.” ${ }^{53}$ Reverend Dill described entire families left to rot in their decaying cottages without burial. He too indicated that disease and starvation were rampant and in one case, a "delirious mother had fed on her dead infant;" a clear indication of the intensity of the crisis. ${ }^{54}$ Mr. Saunderson, owner of O’Kilburn Lodge in Kilburn Ireland, described the growing “dread of future famine” as Ireland fell deeper into the grip of starvation and disease. ${ }^{55}$ These accounts became commonplace as publications around the world began to highlight the intense suffering of the people of Ireland.

\section{The Early Response from the English Media}

Two broad themes appeared in the English press on the eve of the famine that reflected the earlier paternal protectiveness toward the Irish. First was the connection between Irish demands for the repeal of the Act of Union and the issues of poverty and deprivation. While the press was largely hostile to the idea of repealing the Act of Union, the media also stressed that the agitation over the policy was grounded in very real underlying social problems. Throughout 1845 and 1846, a series of special reports from Thomas Campbell Foster of The Times focused on the Irish landlords and their

\footnotetext{
${ }^{52}$ Lord Dufferin and the Hon. G.F. Boyle, Narrative of a Journey from Oxford to Skibbereen during the year of the Irish Famine (Oxford: John Henry Parker, 1847), 7.

${ }_{53}$ Ibid, 5, 11, 18. See also Nicholson, Annals from the Famine in Ireland, 68.

${ }^{54}$ Dill, The Mystery Solved, 14.

${ }^{55}$ Mr. Saunderson, Correspondence From July, 1846, to January, 1847, 172.
} 
destructive absenteeism across the island. Foster acknowledged that when landlords were present and have "attended to the duties of their position,” there were fewer problems of poverty and starvation. However, when the tenants were "allowed to do as they liked" because there was no overseer, the conditions on the estate were deplorable. In his travels to County Mayo, he observed large tracts of undeveloped land because the wealthy landlords "totally neglect their estates." ${ }^{, 56}$ Foster argued that the Irish were "steeped in hopeless poverty” because the majority of landlords were non-residents and let their properties to middle-men. "Oppressed by the hard-fisted middle-man," the tenants were cheated and robbed through arbitrary raises in rent and swift evictions. ${ }^{57}$ Foster's articles raised public awareness about the abuses of landlords in Ireland as he exposed their continued misconduct and neglect. Irish rents were nothing more than an "infamous source of profit, a base and immoral traffic... something not becoming of a gentleman.”58 The Morning Chronicle echoed The Times with a scathing indictment. Landlords in Ireland were guilty of nothing short of "wholesale, unmitigated murder... which has converted Ireland into a lazar-house of death and destitution, and a charnel-house of death.”59 It was the landlords keeping Ireland in a state of social and moral backwardness and it was they who maintained the state of poverty and deprivation across the island.

The second theme prevalent in the media just before the famine centered on the decades of mismanagement in Ireland. Not only were the landlords subjugating the poor, but the policies from past administrations had weakened Ireland's economic structure.

\footnotetext{
56 Thomas Campbell Foster, “The Condition of the People in Ireland,” The Times, September 30, 1845. For a secondary analysis of the role of the landlord in the Irish famine see: W.E. Vaughan, Landlords and Tenants in mid-Victorian Ireland (1994).

${ }^{57}$ Thomas Campbell Foster, “The Condition of the People in Ireland,” The Times, November 18, 1845.

58 Thomas Campbell Foster, “The Condition of the People in Ireland,” The Times, August 27, 1845.

59 “Ireland,” The Morning Chronicle, February 22, 1845.
} 
This concept of economic backwardness was most clearly defined by James Wilson of The Economist. Like economist Adam Smith, his paper was firmly committed to the belief that free trade was the critical ingredient to a successful economy. ${ }^{60}$ The Act of Union, he argued, gave Ireland and England the unique opportunity to create an extensive free market for the mutual benefit of both countries. Like Foster, he recognized that there were "grievances of a very aggravated description... which press most heavily upon the people, and keep them impoverished and discontented" and it was, he also stressed, imperative to give the Irish the same economic advantages as the rest of the United Kingdom. ${ }^{61}$ The Act of Union, while very unpopular in Ireland, served a vital role in creating this free market. Ireland was improving, Wilson argued and if the Act of Union was repealed, it would be "utterly ruinous to Ireland" and "vitally disastrous to England" by triggering a downward spiral of economic events. ${ }^{62}$ Both countries would be forced to raise tariffs to protect local business, thus reducing the competitive edge of the free market. As prices rose, what little industry Ireland had would suffer and because the demand for goods would continue, smuggling and related criminality would increase. With the Act of Union firmly in place, Ireland could be completely integrated into the economic structure of the United Kingdom and thus greatly improve the use of resources and industry across the island. In an article published in The Times, Foster railed against the mismanagement of land under the absentee landlords and argued that Ireland had immense potential in the right hands. ${ }^{63}$ This is the very argument modern historians such as Joel Mokyr adopt in the analysis of the economic aspects of the Famine.

\footnotetext{
${ }^{60}$ The Economist, Issue 10, (October 28, 1843): 139.

${ }^{61}$ Ibid, 139.

${ }^{62}$ Ibid, 140.

${ }^{63}$ The Times, August 28, 1845.
} 
These responses indicate that there was not, as early Irish historians have suggested, a cold genocidal attitude from the English. The writings of Mrs. Nicholson and others were published and reprinted in England; an indication of their popular reception. Foster's economic perspectives were also supported by influential economists such as John Stuart Mill as part of a wider liberal critique on the landlords and economic situation in Ireland. He fervently supported government investment in Ireland, particularly public works projects. He believed that unused portions of wastelands, much of it bog, could be drained and dredged. This land could then be used as valuable farmland. Relief would then come in the form of work rather than as charity. Not only would these projects provided much needed land for the struggling population, but it would improve morale and give the people as sense of purpose. ${ }^{64}$ He strongly disagreed with the proposal to ship the Irish to distant ports in order to solve the problem. He believed that if "three-fourths of the inhabitants of Ireland were to be swept off," either by death or transport, there would be insufficient labor across the island. One-fourth of the population "could not possibly do all the work" required by the wealthy landlords. ${ }^{65}$ These wealthy landlords, he also stressed, needed to remain in Ireland and the tradition of the absentee landlord needed abolished. Not only could the landlord govern his tenants directly, but he would also directly contribute to the Irish economy. A landlord living in the country would "eat Irish bread and beef, wear Irish shirts and breeches, sit on Irish chairs, and drink his wine off an Irish table.” ${ }^{66}$ By living in London or Paris, that same landlord contributes to the economy elsewhere rather than to the Irish labor of his own

\footnotetext{
${ }^{64}$ John Stuart Mill, The Collected Works of John Stuart Mill, lxxxii.

${ }^{65}$ Ibid, 96.

${ }^{66}$ Ibid, 104.
} 
tenants. “By consuming foreign goods,” Mill argued, “you employ foreign labour.”,67 Mill stressed that the "middling classes" of England were not indifferent to the "blessings of good government” and that meant investitures in the improvement of Ireland to ease the suffering. ${ }^{68}$ These articles and books reveal a more complex thread of thought filtering down to the middle class rate-payer of England. The Irish question was not as black and white as Carlyle suggested in his venomous works over the years.

\section{Parliament Responses}

As the Irish fell into the grip of starvation, the government of England attempted to respond to the growing problem while ignoring the major social issues and problems with landlords. Initially, as Foster suggested, the government maintained its policy of a laissez-faire market, and stressed that the economic situation in Ireland would correct itself over time based on the simple principle of supply and demand. Economists of the period, Foster included, stressed a particularly non-Malthusian confidence in the rapid growth of the Irish economy under the free trade system. The government struggled with the growing catastrophe and in a letter to Sir Robert Peel, Home Secretary Sir James Graham acknowledged that "no law will be found easy to feed 25 millions crowded in a narrow space.”69 Debates over aid to Ireland became inextricably linked to the fight against the Corn Laws as The Times called those laws the "worst error ever committed by a statesman" and the Irish famine was not for want of food, but because the "high prices of food” had already begun to "affect the condition of the people."70

\footnotetext{
${ }^{67}$ Ibid, 105.

${ }^{68}$ Ibid, 89.

${ }^{69}$ Letter to Sir Robert Peel, Life and Letters of Sir James Graham, 1792-1861, Volume II, ed. C.S. Parker, (London, 1907), 21.

70 "The Corn Laws," The Times December 5, 1845.
} 
The Corn Laws were import tariffs designed to protect corn prices in the United Kingdom, including Ireland, against competition from less expensive foreign imports. ${ }^{71}$ The law dated back to1813, when a House of Commons Committee recommended excluding foreign-grown corn until domestically grown corn reached $£ 4$ per quarter. ${ }^{72}$ The political economist Thomas Malthus believed this to be a fair price, and that it would be dangerous for England to rely on imported corn. Lower prices would reduce wages, and manufacturing profits would decrease due to the fall in purchasing power of landlords and farmers. Economist David Ricardo, however, believed in free trade arguing that England could use both its capital and population to create a comparative advantage. ${ }^{73}$ When peace returned to Europe in 1814 after the Napoleonic Wars, corn prices dropped and Parliament passed the 1815 Corn Law.

Opposition to the tariffs began from supporters of the free trade policy. Parliament resisted and in 1821 the President of the Board of Trade, William Huskisson, drew up a Commons Committee report which called for a return to the "practically free" trade of the pre-1815 years. ${ }^{74}$ The Importation Act 1822 decreed that corn could be imported when domestically harvested corn reached 80 shillings but imported corn was prohibited when the price fell to 70 shillings per quarter. After this Act was passed, corn price did not rise to 80 shillings until 1828. In 1827 the landlords rejected Huskisson's proposals for a sliding scale. They claimed that the manufacturers only wanted cheap food so they could drive down wages and thus maximize their profits. This argument was

\footnotetext{
${ }^{71}$ Corn in this context refers to the original meaning of any grain, particularly wheat.

721 quarter $=28 \mathrm{lb}$

${ }^{73}$ E.L. Woodward, The Age of Reform, 1815-1870 (Oxford: Clarendon Press, 1962), 61.

${ }^{74}$ C. Schonhardt-Bailey, From the Corn Laws to Free Trade: interests, ideas, and institutions in historical perspective (Cambridge: The MIT Press, 2006), 9.
} 
complicated by the Chartists, who strongly agreed with the landlords' position against the industrial magnates. ${ }^{75}$

In 1828, there was another attempt at compromise. Huskisson and the new Prime Minister, the Duke of Wellington, created a new sliding scale and the Importation of Corn Act was passed. The new Act decreed that when domestic corn was 52 shillings per quarter or less, the tariff would be 34 shillings, 8 pence and when the price rose to 73 shillings the tariff declined to one shilling. ${ }^{76}$ The goal was to maintain prices at a reasonable rate while encouraging a free trade market.

This goal was never achieved and agitation increased for the repeal of the law entirely instead of the complex sliding scale system. Parliament was pressured on repeal for over a decade and although it came up to vote numerous times, the measure always failed. The Great Famine intensified the urgency for repeal. MP Richard Cobden, a manufacturer from the north, argued strenuously for the repeal of the Corn Law and often referenced the crisis in Ireland to support his position. In a speech before Parliament he quoted Joseph Shaw, a worker who spoke before a town meeting in Oldham over which Cobden had presided. Shaw reinforced Cobden and other agitators' arguments that the Corn Laws were heightening the crisis not only in Ireland, but England as well. Shaw stated that when "provisions are high, the people have so much to pay for them that they have little or nothing left to buy clothes with” and then there "are few clothes sold” which leads to overstock and a drop in price. Once the price falls, wages must then fall because overall profits drop. This, Shaw stressed, means that “mills are shut up, business is ruined, and general distress is spread through the country.” Higher wages increases

\footnotetext{
${ }^{75}$ Ibid, 10.

${ }^{76}$ Ibid, 10 .
} 
spending in other market sectors thus leading to an increase in demand. Greater demand, Shaw argued, "makes them rise in price, and the rising price enables the working man to get higher wages and the masters better profits."77 It was this process of falling wages and profits Cobden argued, that was going to send the industrial centers of England "exactly at that state they are in in Ireland."78 The answer to the Irish crisis, according to Cobden, did not rest entirely with public works. He, like Mill and Foster, railed against the landlords for their callous indifference to the plight of their tenants. He acknowledges it was this indifference that heightening the suffering of the people. But, he stressed, it was the also the availability of affordable food in a free trade market that was vital to ending the crisis as well. ${ }^{79}$ If the Corn Laws remained in place, this would never happen and Cobden pointed out, England may see a similar crisis on her shores as well.

Peel resisted the repeal of the Corn Law and instead became focused on agricultural reform in order to modernize the Irish social and economic structure. The archaic division of labor still in use across the island and antiquated farming techniques kept Ireland impoverished. New scientific methods of farming were necessary in both Ireland and England and all agricultural protection needed eliminated. If farmers utilized the latest technologies and shook off the lethargy of government protection, agriculture would thrive. ${ }^{80}$ The Irish representation in Parliament was divided over solutions to the problem and as O’Connell's health declined, the party lacked a strong united front to push a more focused agenda.

\footnotetext{
${ }^{77}$ Richard Cobden, Speeches on Question of Public Policy, Volume III (London: MacMillan, 1870), 251

${ }^{78}$ Ibid, 310.

${ }^{79}$ Ibid, 325.

${ }^{80}$ D.C. Moore, “The Corn Laws and High Farming,” Economic History Review, Second Series, XVIII (1965), 544-561.
} 
The first attempt at a solution placed the responsibility for improvement firmly in the hands of the local Irish elite as Peel attempted to change Ireland from above. While Peel did not believe in Cobden’s economic arguments against the Corn Laws, this policy was a direct acknowledgement of the repeated agitation against the abuses of landlords. The Devon Commission of 1843-1845 was aimed primarily at encouraging the landlords to make improvements to their estates. Estate owners were encouraged to drain swamps and marshlands, improve sewage systems, diversify their crops, and generally improve the living conditions of their tenants. ${ }^{81}$ The minority Whig government also decided that landlords across the island, largely Tories, were to pay to support the poor of their own country. There was little faith in direct intervention as a solution, so Parliament let those at home carry the burden rather than add the financial problems onto the backs of the English as well. This was only reasonable, as world markets were experiencing economic fluctuations and creating an unstable business environment across Europe. The landlords revolted in anger and most refused to pay any taxes whatsoever. Local Poor Law commissioners and Poor Law guardians could not do their jobs properly without funding and many were forced to manipulate their records in order to appear as if they were providing help when in reality, they were unable to with such limited funding. ${ }^{82}$

In the autumn of 1845, the Peel administration began a limited relief effort through a variety of public works designed as temporary measures until free trade could begin to regulate the economy. It was popular in Ireland as it brought some aid, but public criticism rose sharply to what was seen as a lack of any serious response. Parliament was accused of "not a particle of remedy... for the distress" that continued to

\footnotetext{
${ }^{81}$ The Times, June 12, 1846.

${ }^{82}$ Ó Gráda, Ireland Before and After the Famine,129.
} 
mount. The media lambasted Peel for ignoring reports of "ragged crowds gaunt wretches demanding food” and viciously attacked the government for creating an "unmanageable” situation in Ireland. ${ }^{83}$ The London based newspaper, The Examiner, even accused Peel of extreme "fears of Popery" and outright hatred for Ireland "as the majority of the Tory party do" which the paper charged outweighed any economic sense toward the poverty in Ireland the years before the crisis manifested and reached its peak. ${ }^{84}$

By October of 1846, the Whigs expanded the public works Peel had started. Soup kitchens multiplied across the country and the Poor Laws, originally enacted in 1838, became the staple of relief across Ireland. Heated debates had taken place concerning Poor Laws for Ireland. Supporters argued that if Ireland had the "same poor laws as England,” then “why should the Irish migrate?” The "burdens of the English” created by the continued immigration of poor Irish would end as responsibility for their relief shifted to Ireland. England had a "right to insist on a remedy for the evil entailed on them” because of the differences in the laws between the two countries. ${ }^{85}$ Detractors argued that the laws would only increase the tax burdens on a country already in crisis. England, according to MP Sir John Walsh, "has felt the Poor Laws to be... an almost irremediable evil” and an Irish version would only add to the burdens on the "affluent upper, and middling classes.” ${ }^{86}$ Supporters hammered on the idea that the public needed a “guarantee... against the undue multiplication of paupers" on English soil and throughout

\footnotetext{
83 “Art.X.-1. Lord's Spencer's Speech on the Repeal of the Corn Laws,” Westminster Review, 41:1 (March: 1849): 265-266, 278. Similar attacks on Peel's government can be found in "Art. VIII. Speech by Lord Viscount Palmerston, on the State of Public Affairs, In the House of Commons on Wednesday the $10^{\text {th }}$ of August, 1842," Eclectic Review, 7 (November: 1842): 579-604.

84 “Sir Robert Peel’s Perplexities,” The Examiner, 1663, December 15, 1839: 785.

${ }^{85}$ The Morning Chronicle, 19466, January 17, 1832.

${ }^{86}$ Sir John Walsh, On Reform of Parliament; and on Ireland (London: James Ridgway, 1831), 2, 35.
} 
the early 1830s, the idea of an Irish Poor Law “made rapid progress” in Parliament in response to public pressure. $^{87}$

\section{The Irish Poor Laws}

In response to this demand for relief from the first wave of Irish immigrants and in spite of the resistance by some in government, Parliament passed the Irish Poor Laws. They were structured much the same as England's but there were, however, several critical differences between the English Poor Laws and those of Ireland. First, relief in Ireland could only be administered from within the workhouse as outdoor relief was expressly forbidden. This meant entire families had to relocate or split up in order to receive assistance. Second, there was no specific right to relief as no categories of poverty or rules for assistance had been established. Aid could be therefore distributed as local officials saw fit rather than to those most in need. The Irish Poor Laws were guided by the principle of less eligibility, meaning that relief was to be the last resort. Food was limited and bland, the workhouse labor brutal, and the rules of the workhouse were strict and regimented. ${ }^{88}$

The law, passed in 1838, was heavily amended in 1847 and instead of providing relief, only added to the growing burden. One facet in particular that greatly added to the misery for the people and ensured greater economic prosperity for the English landowners was the Gregory Clause. Often referred to as the "infamous Gregory clause,” it prohibited any Irish family owning more than a quarter of an acre of land to receive relief, either in or out of the workhouse, until they gave up their land. Even children were

\footnotetext{
${ }^{87}$ The Morning Chronicle, 18894, March 17, 1830, The Times, March 19, 1833.

${ }^{88}$ Christine Kinealy, "The Role of the Poor Law During the Famine,” in The Great Irish Famine, ed. Cathal Póirtéir (Dublin: Mercier Press, 1995,) 105-106.
} 
barred from the workhouses until the family surrendered its entire holdings. ${ }^{89}$ This opened the door for the eviction of small tenant farmers on a large scale in order to convert the land from tillage to livestock or dairy farming. Canon John O’Rourke published a history of the Irish Famine in 1874 and described the Gregory clause viciously when he said that, “a more complete engine for the slaughter and expatriation of a people was never designed.” O’Rourke called Gregory a “pretended friend of the people" and his contribution to the devastation of Ireland "should be for ever remembered by the descendents of the slaughtered and expatriated small farmers.”90

The goal of the English government was contradictory in scope. Although the Poor Laws were designed to bring relief to the native population, the ever-increasing limitations on eligibility actually ensured that fewer people received aid as the laws were changed, thus reducing the expenditures from the government. This severe clause also served a moral end in that it created a kind of "means test" to distinguish between those poor deserving aid and those who simply did not want to work. Sir Charles Trevelyan, the assistant secretary to the Treasury, firmly believed that there were scores of persons who needed "struck off the list" of aid because they were abusing the system and could work. ${ }^{91}$ The Irish, according to Trevelyan habitually "conceal their advantages, exaggerate their difficulties, and relax their exertion” all in order to apply for relief courtesy of the English taxpayer. ${ }^{92}$ Any assistance should be handed out with harsh

\footnotetext{
${ }^{89}$ Colm Tóibín, The Irish Famine (London: Profile Books, 1999), 9-10.

${ }^{90}$ Canon John O’Rourke, A History of the Irish Famine of 1847, reprint (London: Bibliolife, 2008$), 337$.

${ }^{91}$ Sir Charles Trevelyan, The Irish Crisis (London: Longman, Brown, Green and Longmans, 1848 ), 86.

92 Ibid, 184.
} 
penalties, stiff regulations, and should come directly from the Irish people rather than from the coffers of the English. ${ }^{93}$

Daniel O’Connell had presented a strong case in Parliament against the Poor Laws as they were written. He pointed out that if the system of local taxation, such as that used in England, was enacted, the funding would be woefully inadequate for Ireland. As the law was written, the "occupier of land, who held it without any profit” would pay one half of the taxation. The "occupier of land" who already paid "more than it was worth" according to O’Connell, was then to pay “one half of the entire rate” as the occupier. This method of taxation would then only serve to increase absenteeism and increase immigration as the poor fled the heavy burden. ${ }^{94}$ Sir John Russell responded by saying that the Poor Laws were an "introduction of the means of order" to England and they would do the same for Ireland. ${ }^{95}$ Trevelyan and other supporters of the measure believed that the stiff regulations embedded in the new law would prevent the crisis O’Connell outlined, but they failed to thoroughly explain how this was to be achieved. Prominent economists such as Nassau William Senior and Richard Whately denounced the changes in the laws, but the Gregory Clause was enacted in spite of any objections.

\section{Relief Failure and the Conflicts of Business}

The direct famine relief effort from the English government was quite limited and failed to meet the vast demands of the population. Rice, for example, was among the initial shipments of food to the island. The poor, however, complained that it made them ill. The English media dismissed this and accused them of being ungrateful for the

\footnotetext{
${ }^{93}$ Ibid, 185.; For a secondary analysis of the role of Charles Trevelyan see: Robin Haines, Charles Trevelyan and the Great Irish Famine (Four Courts Press, 2004).

${ }^{94}$ Daniel O’Connell, “Poor Laws (Ireland),” House of Commons Debate, Vol. 40, (February 9, 1838): $952-$ 953.

${ }^{95}$ Ibid, 966.
} 
support. In reality, travelers reported that the local population did not have adequate supplies of fuel for their stoves. Supplies of coal were almost non-existent and the Irish mixed what little could be found with clay. ${ }^{96}$ As they could not cook the rice thoroughly, they were instead eating it raw or partially cooked, and thus becoming ill. ${ }^{97}$ As Prime Minister, Lord John Russell personally investigated the reports of substandard relief supplies. Cooks prepared him a meal made from the Indian meal cake imported into the country and he found it "edible and pleasant."98 However, Mrs. Nicholson, in a conversation with one of the cooks, discovered that his dish had been prepared with “suets, fats, sweets, and spices” that were unavailable to the poor, and like the rice, the Irish were eating it half-cooked and plain, thus rendering it unsafe to eat. ${ }^{99}$

Import and export information during the height of the famine also reflected a conflicted policy toward the relief effort. While charities were struggling to aid the sick and starving, foodstuffs left Irish ports by the millions of tons. The first year of the famine, 3,251,901 quarters of grain were exported directly in English ports for sale to the English people. ${ }^{100}$ In 1847 , at the height of the famine, almost three million quarters of wheat and eleven and a half million quarters of oats were exported out of Ireland for English ports and abroad. That same year, just over 2 million tons of potatoes left Irish ports as well. In 1851, Ireland exported almost four and a half million tons of potatoes and in 1853, the tonnage increased to just over five million. ${ }^{101}$ In $1850,196,988$ heads of cattle left Irish ports as well as 278,641 sheep, with 201,811 heads of cattle and 241,061

\footnotetext{
${ }^{96}$ Mathew, 241.

${ }^{97}$ Nicholson, Annals from the Famine in Ireland, 80.

98 Nicholson, Annals from the Famine in Ireland, 80.

99 Ibid, 33.

${ }^{100}$ Thom's Statistics of Great Britain and Ireland (Dublin: Alexander Thorn, 1868), 143. A quarter is equivalent to eight bushels.

${ }^{101}$ Thom's Statistics of Great Britain and Ireland (Dublin: Alexander Thorn, 1868), 123.
} 
sheep imported directly into England. 95,062 swine were also exported that same year. 16,031 pounds of butter and 263,284 pounds of wheat and flour left for foreign shores. ${ }^{102}$ In 1855 , a total of $£ 50,836$ of beef and pork, $£ 25,490$ of corn and flour, and $£ 82,461$ of butter and cheese left Irish ports after a decade of starvation and deprivation had ravaged the island. ${ }^{103}$ In his 1876 work The Last Conquest of Ireland (perhaps), author John Mitchel analyzed England's export policies and Ireland's growing capacity during the famine years. He argued that Ireland produced "more than double the needful sustenance for all her own people,” but the goods were unloaded at foreign ports, such as Brazil, which received the "best quality of packed beef” in Ireland. ${ }^{104}$

These figures did not represent a new trend in business methodology between Ireland and England. It was simply a continuation of the common practice of removing resources from the island for profit under the free trade system established just after the Act of Union. In the city of Limerick, for example, the export of wheat in 1822 was 102,593 barrels. A decade later, that figure doubled to 218, 903 barrels. Another profitable export, oats, reflected the same business pattern. The export total for 1822 was 155,000 barrels. By 1833, that total had increased four hundred percent to 408,000 barrels. ${ }^{105}$ Ireland's agricultural resources were seen as a cash cow for wealthy landowners and as travelers such as Mrs. Nicholson observed, the upper classes had little regard for the cost to the native population as critical supplies were shipped elsewhere.

The Irish had no purchasing power and therefore foreign markets were the only source

\footnotetext{
102 Ibid, 119 and Thom's Irish Almanac and Official Directory, with the Post Office Dublin City and County Directory (Dublin: Alexander Thom and Sons, 1852), 258.

103 Thom's Statistics of Great Britain and Ireland (Dublin: Alexander Thorn, 1868), 111.

${ }^{104}$ John Mitchel, The Last Conquest of Ireland (perhaps) (Glasgow: Cameron \& Ferguson, 1876), 8.

${ }^{105}$ Henry D. Inglis, A View of the State of pauperism in Ireland; Its Evils and Its Remedies (London: J. Ridgway and Sons, 1836), 60.
} 
for profitable business ventures as dictated by the free trade market system. The poverty of the natives did not figure into the capitalist framework that Foster and other free market advocates had pushed for so heavily as a solution to the famine crisis.

The actual figures for crops and livestock in Ireland support the export figures and reflect a dismissing attitude toward the growing crisis. While the native population died of starvation and disease, 743,871 acres of wheat was harvested in 1847 . That same year, 2,200,370 acres of oats, 23,768 acres of beans, and 284,116 acre of potatoes were also harvested. These figures remained fairly steady throughout the entire course of the famine, and in 1855, after a decade of famine and disease, 982,301 acres of potatoes were harvested that year. ${ }^{106}$ In 1856 , the first year the blight did not devastate the potato crop, 2,036,181 acres of wheat and 1,104,590 acres of potatoes were harvested. ${ }^{107}$

The country was also rich in meat products with almost $£ 6$ million worth of livestock registered in 1841 and over seven million registered in 1851. In 1847, for example, there were two and a half million cattle and just over two million sheep in the country and this was one of the worst years of the famine. ${ }^{108}$ As export figures indicate, much of this food, precious to the native population as a means of survival, was sent abroad over the course of the ten year famine. The monetary value of these resources took priority over the dire needs of the native population. John Mitchel, in his journal written while imprisoned in England for political agitation, stressed that in every one of the critical famine years, "Ireland was exporting to England food to the value of 15 million pounds sterling” and had “on her own soil to each harvest, good and ample

\footnotetext{
106 Thom's Statistics of Great Britain and Ireland (Dublin: Alexander Thorn, 1868), 129.

${ }^{107}$ Thom's Irish Almanac and Official Directory of the United Kingdom (Dublin: Alexander Thom and Sons, 1857), 120.

108 Thom's Statistics of Great Britain and Ireland, 135.
} 
provisions for double her own population.” Peel's government justified these exports as the only means for Ireland to accumulate wealth and improve its economy, thus creating a deep division in opinions on the actual solutions to the growing problem. ${ }^{109}$

\section{Shifting Perceptions as the Crisis Deepens}

In spite of the abundance of food resources available across Ireland, the famine continued to worsen as the years progressed. Prominent Irish politicians, such as Daniel O’Connell, sought relief from the English government and the English people to help stem the devastating tide of death. By 1847, however, the paternal benevolence toward their simple Irish neighbors was rapidly coming to an end. Between 1847 and 1848, events in Ireland created a noticeable shift in tone in the popular press in England. This shift stemmed from two very specific facets of the famine. First was the perception that little to nothing was making a difference, including the increasing financial burden of the Poor Laws of both nations. Secondly, violence in Ireland was escalating as the crisis deepened which culminated in the poorly executed uprising in 1848. The English began to see not only a money pit across the Irish Sea, but a nation hostile and traitorous in the face of English generosity. These two elements of the crisis in Ireland triggered a distinct shift in public perception and public opinion of the natives of Ireland. This shift was later reinforced by the impact of immigration throughout the 1850s and thus contributed to the negative stereotypes so prevalent in the last decades of the 1800 s.

Prior to 1847, the English media continued to promote the paternal relationship between England and Ireland. The press coverage of the famine was largely sympathetic as reports such as those from Mrs. Asenath Nicholson and temperance minister Father Mathew became more common. The famine was attributed to crop failure particularly as

\footnotetext{
${ }^{109}$ John Mitchel, Jail Journal: or five years in British prisons (New York: Office of the Citizen, 1854), 19.
} 
the blight was not restricted to Ireland. In November of 1845, The Times reported on the European-wide calamity and warned of a "prospective dearth in England” because of summer wheat crop failures. ${ }^{110}$ The Irish were one group among many that were victims of a wide-spread and most notably, singular event taking place that year.

By 1846, however, England began to suffer from compassion fatigue. The famine of Ireland had ceased to be a singular event, but was instead proving to be an ongoing crisis forced upon the English time and again. The tone in the press began to change, and The Times as the most prominent of the English media set the stage. The newspaper announced that it had "purposely abstained of late from directing the attention of the public to Ireland" as the enduring famine had become "tedious and wearisome as a ten times told tale.” Readers were "beginning to be a little tired of Ireland” and The Times expressed its "most entire sympathy in their fatigue."111 The death, starvation and deprivation were the same plotlines the English had been hearing from their neighbors for decades. Poverty was, in the eyes of the rate-paying middle class, a never-ending conundrum for the Irish and one in which they wanted no part. Charity was "no real relief” to the endless distress of the Irish. ${ }^{112}$ In 1830, for example, Mr. John Dyas, a landowner in Ireland, reported that if the Irish "remained at home... they would have nothing to eat.” He stressed that "they could not live, neither could they get any employment.”113 Henry Inglis, author and traveler, wrote about the parish of Castletown in County Westmeath during his visit in 1834. With a population of 10,553 people, over

\footnotetext{
${ }^{110}$ The Times, November 6, 1845: 4.

111 The Times, November 11, 1846.

112 “Charity as a Remedy in case of famine,” The Economist, Issue 118 (November 29, 1845): 1193. (11921193)

${ }^{113}$ Mr. John Dyas, First report of Evidence from The Select Committee on the State of the Poor in Ireland. Minutes of Evidence: 24 March-14 May, 589:II (June 30, 1830): 32.
} 
7,000 were sleeping on floors of damp cabins without bedsteads. ${ }^{114}$ Limerick, he reported, was filled with paupers in "utter and hopeless wretchedness" living in filthy cellars and hovels. ${ }^{115}$ He described large numbers of "poor wretches dying from want" and using the town of Mitchelstown as an example, he reported over eighteen hundred people in a state of starvation. ${ }^{116}$ These were the same horrific tales coming out of Ireland's current famine. Irish issues were dominating Parliamentary time at the expense of pressing English issues. The famine, The Times argued, was confined to the "weak extremities of the empire,” and it was time to leave it alone and move on. ${ }^{117}$ Besides, the natives of the island were "pretty well accustomed to it by this time," so the English populous "need not put ourselves in a hurry about them." ${ }^{\text {"118 }}$ These people, according to the Liverpool Mercury, bore the "taint of inferiority" and their plight had "more to do with [their] present degradation than Saxon domination." ${ }^{\text {"19 }}$ The subject had become distasteful, and needed to quietly fade into the background of English concerns. ${ }^{120}$

\section{Growing Opposition}

It was, according to the English media, the union of the Whigs with Daniel O’Connell that created the crisis for England in relation to the Irish. Because of their “inability to maintain their own,” England was forced to create the Irish Poor Laws. In 1845, Punch depicted O’Connell as a giant potato holding a begging plate out for English alms. ${ }^{121}$ Maintaining the English poor was one thing, but the added tax burden on the

\footnotetext{
${ }^{114}$ Henry D. Inglis, A View of the State of pauperism in Ireland; Its Evils and Its Remedies (London: J. Ridgway and Sons, 1836), 35-36.

${ }^{115}$ Ibid, 34.

${ }^{116}$ Ibid, 32, 29.

${ }^{117}$ The Times, September 8, 1846.

${ }^{118}$ The Times, January 5, 1846.

${ }^{119}$ The Liverpool Mercury, August 1, 1848.

${ }^{120}$ George Lewis Smith, Ireland: Historical and Statistical (London: Whittaker \& Co., 1849), 33.

${ }^{121}$ Punch, 9 (July-December, 1845): 255.
} 
English people, the "inward bleeding" of their purse strings, was too much. ${ }^{122}$ The middle class had been “decidedly opposed to the passing of the Romish Relief-bill,” and according to the media, "remain still of the opinion, that it was a dangerous and most erroneous measure.”123 The media began to argue that the Poor Laws were simply a "scheme for the promotion of emigration on an extensive scale” as people continued to flee Ireland en mass. ${ }^{124}$ This was an ironic position as this was the very crisis O’Connell had predicted when he argued so passionately against the passage of the Irish Poor Laws. Popular opinion argued that Peel gave in to the demands of O’Connell and his ilk because the Irish politician threatened to rouse the "worst passions of his ignorant countrymen" against the English. Parliament had given in to ruffians and gave control to a "man whose hatred of [England] was opened and avowed" and this was "enough to stir the bile of a less proud race than the British.”" ${ }^{25}$ Giving in to this "leader of a band... leagued together for the purpose of plundering church and state” was enough to diminish public confidence in "those men whom they had raised to power." This "unnatural union” was a drain on England and like previous criticism of the Peel administration, needed to come to an end. ${ }^{126}$ Again, this position is ironic as there was a deep rift between O’Connell and the more violent faction of the Irish nationalist movement. England was being drained and, The Times stressed, it was time to stop wasting money on what was essentially an act of God in a country used to famines and deprivation. ${ }^{127}$

\footnotetext{
122 “The End of the Beginning," Fraser's Magazine for Town and Country, 24:141 (September: 1841): 255.

123 "The Crisis: And, What is to Follow?" Fraser's Magazine for Town and Country, 21:121 (January: 1840): 117.

124 "Condition of Ireland,” The Preston Guardian 1791, December 24, 1846.

${ }^{125}$ Ibid, 255.

${ }^{126}$ Ibid, 254-255.

${ }^{127}$ The Times, February 19, 1846: 4.
} 


\section{The Financial Impact from the Poor Laws}

The Poor Laws, passed in 1838 and amended in 1847, were initially perceived as a subsidiary to government sponsored relief schemes, but after 1847, they were the main source for famine relief. Yet even with these various forms of aid, years had passed and to the English, nothing had changed across Ireland in spite of their increased tax burden. According to the popular media, by 1847 this burden amounted to $£ 2,400,000$ and threatened to exceed $£ 8,000,000$ if the famine continued unabated. ${ }^{128}$ Actual statistics reflect a more accurate picture of the tax burden the English people were carrying under the Irish Poor Laws and although it was far less than the media portrayed; it was nonetheless significant. O’Connell's fears had materialized and government subsidies, in the form of temporary relief, became necessary. In February 1847, Parliament passed the Temporary Relief Act generously financed with $£ 2,225,000$ of public monies. ${ }^{129}$ In 1849 , 2,142,766 people applied for relief at a total of $£ 2,177,651$. In 1850, during a Parliamentary debate, MP Scrope argued that the Irish were simply not carrying their fair share of the burden under the Poor Laws. He presented evidence from eleven different Irish relief unions, four in Clare, five in Mayo, and two in Galway. In 1849, the total relief paid out from these eleven unions was $£ 725,000$, of which sum the unions themselves had contributed only £250,378l. The remainder, nearly half a million pounds, "had either been made up already, or was to be made up, from the pockets of the ratepayers of England.” The city of Limerick alone was, according to Scrope, carrying a debt of $£ 61,000$ with 12,000 paupers in the workhouse, of whom 9,358 were able-bodied and not working. During that same debate, Colonel Sipthorp pointed out that the total

\footnotetext{
128 “Ireland and the Famine,” The Liverpool Mercury, 1869, February 26, 1847.

${ }^{129}$ Kinealy, “The Role of the Poor Law During the Famine,” 113.
} 
amount of loans and grants made to Ireland during the last ten years amounted to "no less than $£ 12,027,432 ”$ and he stressed that the loans Ireland had paid back only amounted to $£ 3,184,421$; leaving a balance "still due of five millions and a half_-an awful sum.” MP Sipthorp argued that the English taxpayers were shouldering more and more of the Irish financial burden and the "public had a right to know what chance there was of getting it back again,” and he believed, based on the prior ten years, there was little chance of that happening. MP Scully supported Sipthorp’s argument against further loans, indicating that the Irish were in no "condition to pay" for either their poor or their debts. ${ }^{130}$ By 1852 , the total number of requests for aid dropped to 519,775 with a total of $£ 883,267$, but this also reflected a massive drop in the total population of Ireland by almost two million people as immigrants headed to greener pastures, most notably England, thus increasing the pauper rolls of the major industrial centers. ${ }^{131}$ The stories of "pallid misery and hectic fever... privation and disease in their severest and most agonizing forms” was a tired refrain from across the Irish Sea after years of support with little to show for it from the point of the view of the English. ${ }^{132}$ From the English perspective, the peasant of Ireland "is now what he has always been," and that was poor, starving and a drain on England, especially as the economic situation worsened in the late 1840 s. $^{133}$

As the Great Famine worsened, contradictory evidence and arguments became common. Solutions to the crisis were obviously failing and economists, politicians, and agitators were scrambling to regroup and provide new answers. Was Ireland an economic

\footnotetext{
${ }^{130}$ Great Britain, “Distressed Unions Advances (Ireland) Bill,” House of Commons Debate, Vol. 110, (April 26, 1850): 845.

${ }^{131}$ Thom's Statistics of Great Britain and Ireland, 103.

132 “Irish Legislation,” People's Press January 11, 1848: 8 and Henry D. Inglis, A View of the State of pauperism in Ireland; Its Evils and Its Remedies (London: J. Ridgway and Sons, 1836), 23.

133 George Lewis Smith, Ireland: Historical and Statistical (London: Whittaker \& Co., 1849), 22.
} 
drain on England or was it a source of wealth? Were just its resources a source of wealth and the people a drain? Could the population be helped without taxing England? And most critically of all these questions- just how responsible was England at the end of the day?

The Victorian Era was the beginning of the modern concept of state responsibility for the welfare of its people. Prior to this period, starvation, deprivation, poverty and substandard living were not seen state problems. In his 2004 work, The origins of the British welfare state: society, state, and social welfare in England and Wales, 1800-1945, Bernard Harris traces the evolution of this state responsibility. He posits that voluntary social charity, such as that which the Quakers provided in Ireland early in the Famine, laid the groundwork for a shift in the role of government in England. Throughout the 1800s, there was a gradual shift from private aid to a government welfare system. The Poor Laws were a key example of this state responsibility. There was a sense of charity toward the lowest levels of society, and the voting population of England supported this shift in their government because of it. ${ }^{134}$ Virginia Crossman relates this shift to the increasing democratization of England. As the voting middle classes developed a strong sense of their political power, they also developed a more complex understanding of freedom and liberty coming from the Enlightenment as those terms applied to the lower classes. ${ }^{135}$

A critical factor in this charitable stance was, however, the implication that it was limited in scope. In their 2007 article on welfare reform in 1990s America, political

\footnotetext{
${ }^{134}$ Bernard Harris, The origins of the British welfare state: society, state, and social welfare in England and Wales, 1800-1945 (London: Palgrave Macmillan, 2004).

${ }^{135}$ Virginia Crossman, "The Humanization of the Irish Poor Laws: Reassessing Developments in Social Welfare in Post-Famine Ireland,” in Being Poor In Modern Europe: Historical Perspectives 1800-1940, ed. Inga Brandes, (London: Peter Lang, 2006): 229.
} 
analysts Joe Soss and Sanford F. Schram posit that if a public begins to feel that too much of their government's resources are being directed at the lower income population, as it seemed to be throughout the Johnson era in the United States, a slow backlash will occur. By the late 1970s, as the economy faltered, middle and working class white Americans started to scapegoat the low income population, particularly minorities. Public opinion supported cutbacks in welfare benefits and more limited resources for the poor. This is a trend, they argue, that is not unique to the United States or the 1970s. It is a pattern of backlash behavior with its roots in the delicate balance between the welfare state and the demands of the largest voting blocks within that state. ${ }^{136}$ This is the same pattern of backlash that began in Victorian England as the Irish pressed middle class charitable attitudes. How then can relief be curtailed without seeming uncharitable? This question will remain unanswered until the pseudo-sciences of the second half of the 1800s provide a rationale for poverty as a biological trait.

\section{The Pauper Rolls in England as the Irish Arrive}

The Poor Laws in Ireland tried to provide enough relief, but the measure failed to stop the waves of immigrants that flooded the large industrial centers of England. Rather than providing any relief, this only shifted the tax burden to English shores. These immigrants were poor, uneducated and filled the dockets of the poor rosters in the English parishes. In 1840, England and Wales recorded a total of 1,199,529 paupers on its rolls. By 1845, that number had increased to 1,470,970, an estimated one-tenth of the population, and that was in the first year of the famine. ${ }^{137}$ In 1840 , several years before the actual height of the crisis, the government deficit was nearly £8,000,000 and media

\footnotetext{
${ }^{136}$ Joe Soss and Sanford F. Schram, “A Public Transformed? Welfare Reform as Policy Feedback,” The American Political Science Review, Vol. 101, No. 1 (February, 2007): 112.

${ }^{137}$ Great Britain, The Poor Law Commission (London: G. Luxford, 1846), 10, 11.
} 
sources argued that the government couldn’t account for the “enormous waste” and stressed that the only source could be the "financial mismanagement" and overspending due to the Poor Laws. ${ }^{138}$ Whether this was a completely accurate statement or not was irrelevant to the people of England. It simply served to reinforce the impression that the Irish in Ireland and its immigrant population in England were a money pit and the continually increasing demands for relief during the famine years did nothing but add to this perception. Immigration, according to the press, could not be seen "in any other light than as a great evil” as it brought the poor in record numbers to English shores. ${ }^{139}$

The actual expenditures on the poor seemed to reinforce this financial drain the media presented to the public. In 1852, Parliament spent $£ 4,897,685$ on relief for the poor across England and Wales. By 1855, that figure had risen almost by almost a million pounds to $£ 5,890,041 .{ }^{140}$ The unredeemed debt funded in Ireland as of the $5^{\text {th }}$ of January, 1851, midway through the famine period, totaled $£ 40,644,014$ and had steadily risen over the years. ${ }^{141}$ The media announced that "every working man in this island has an Irish peasant on his back” from the tax burden they demanded. ${ }^{142}$ The English had "paid so many millions of money which they could not well spare” to keep the Irish from death’s door, but to no avail. ${ }^{143}$ These figures only heightened the public perception that England was shouldering more and more of the economic burden of its neighbor across the sea and increased the growing frustration of middle class England toward the Irish people.

\footnotetext{
138 “The End of the Beginning,” Fraser's Magazine for Town and Country, 24:141 (September, 1841): 258.

139 The Times, Apri1l, 1846: 5.

140 Thom's Statistics of Great Britain and Ireland, 124.

${ }^{141}$ Thom's Irish Almanac and Official Directory, with the Post Office Dublin City and County Directory, 248. This debt included all annuities, Imperial loans (those which were not to be paid back, also known as permanent debt), and pensions.

${ }_{142}$ The Times, February 5, 1847.

143 Illustrated London News, July 29, 1848.
} 
The Irish immigrants were being driven by the devastation of Ireland's economy due to policies established before the famine and the impact the crisis had on the small farms that resulted from the policies. The population boom experienced in the early 1800s put great pressure on the Irish agricultural system. Families subdivided their small farms so that sons could have land to grow their own potato crops. During the Napoleonic wars, the Irish also chopped up landholdings to gain more benefit from the increased demand for corn. High food prices created a rent scale unmaintainable after the wars ended. ${ }^{144}$ As the famine struck, the crop failure hit small farms particularly hard as many families relied on the tiny harvests for their subsistence. Those families that rented land found they had no harvest to sell to pay the exorbitant rents their landlords demanded. Small farms were swallowed up by larger, wealthier landowners, thus forcing the native population off their generational property and into deeper poverty.

\section{Ireland's Economy Prior to the Famine}

Reverend Dill's extensive treatise on his travels through Ireland during the famine present a striking contrast to what Ireland's economy was like prior to the Famine and in the midst of the growing tragedy. By compiling statistics from both the 1841 and 1851 census, he was able to draw the crisis into sharp relief, including the pattern of land ownership. In 1841, the Irish national revenue only represented one eleventh of Great Britain’s total revenue. Out of £52,000,000 sterling, Ireland’s contribution was a mere $£ 4,500,000$. The proportion of people employed in factories across the island was onetwenty third that of England. Out of the total land holdings, one seventh did not exceed one acre. One-third of the farms ranged from just above one acre to around fifty acres. Only one-twentieth of the farms were above fifty acres. At least two-thirds of the land

\footnotetext{
${ }^{144}$ Nicholas Mansergh, The Irish Question (London: George Allen and Unwin, 1965), 32.
} 
was "wretchedly cultivated" and the majority of people lived a little above subsistence level by growing potatoes, and if fortunate, raising a few pigs. By 1851, the land holdings under fifteen acres had been reduced by half, and at least 1,500,000 people were displaced. ${ }^{145}$ The Famine thus resulted in a major consolidation of land. Fewer people owned land, and therefore, land became scarce even with the decline in population. This shift occurred in part because of the very relief effort aimed at helping the poor. Relief legislation denied assistance to any person who held more than one-quarter acre of land. The law thus forced thousands to give up their lands in order to prevent starvation. Starting in the 1850s, landowners concentrated on raising cattle instead of crop production on these larger tracts of land. Only in the West did the smaller farm tradition continue. Greater profits could be made through raising livestock, and landowners consolidated their holdings to take advantage of the agricultural shift.

With each generation, farmers had divided the land into smaller plots, relying more and more on what Rev. Dill called the "staple food of poverty or sloth," the potato. "No prosperous country depends on it," Dill declared, yet an entire nation had come to live and die by it. ${ }^{146}$ Once Phytophthora infestans attacked the crop a "death sentence" fell on any farm with the potato blight. ${ }^{147}$ The province of Connaught served as an example of the economic stress. Two million acres of 4.4 million acres were not fit to be farmland. In this region, 78 percent of the people depended on agriculture. The land held 386 people per square mile of cultivable land, whereas the rest of Ireland held 335 people per square mile. ${ }^{148}$ The region was overcrowded, poor, and the majority of people relied

\footnotetext{
145 Dill, The Mystery Solved, 10.

146 Ibid, 12.

${ }^{147}$ R.F. Foster, The Oxford Illustrated History of Ireland (Oxford: Oxford University Press, 1989), 201.

${ }^{148}$ Mansergh, The Irish Question, 27.
} 
on subsistence farming. These were the very conditions that when the blight hit year after year, set the stage for the ravaging effects of starvation, disease and death. The tiny farms were simply unable to sustain the population once the blight spread. Economist J. R. McCulloch argued that the "notion of the equal and unalienable right of all their children to the inheritance of their father's property" was, in the face of the growing crisis, "ruinous and absurd in practice." 149

Historians have argued that this pre-famine agricultural system played a major role in the escalating crisis as the potato crop failed across the island. Kevin O'Neill, in his work Family and Farm in Pre-Famine Ireland, posits that Irish agriculture was essentially peasant subsistence farming and the ecosystem of the island, with its cool, wet climate and poor soil drainage, limited the crop variety. This limitation, combined with the very small land holdings, set up a delicate agricultural balance with the potato at the center of production. ${ }^{150}$ Christine Kinealy, in her work, A Death-Dealing Famine: The Great Hunger in Ireland, contrasts England and Ireland in the pre-famine years. She points out that while England experienced rapid industrialization in the early decades of the 1800s, Ireland did not share in the technological developments of it neighbor, even under the free trade with the Act of Union. After 1815, when the last tariffs on Irish goods were eliminated in the culmination of the free trade policy, Ireland could not compete in industrial output. Agriculture became even more important as what little industry existed collapsed and farmers were forced to eke out a living on tiny plots. ${ }^{151}$ Cormac Ó Gráda, in his both of his seminal works on the famine also stresses the small

\footnotetext{
149 J.R. McCulloch quoted in Ó Gráda, 181.

${ }^{150}$ Kevin O'Neill, Family and Farm in Pre-Famine Ireland: The Parish of Killashandra (Wisconsin: University of Wisconsin Press, 2003), 32-33.

${ }^{151}$ Christine Kinealy, A Death-Dealing Famine: The Great Hunger in Ireland (London: Pluto Press, 1997), 29-31.
} 
farm tradition throughout Ireland in the pre-famine years. He argues that it was this tradition and the significant role of the potato in the Irish diet that set the stage for calamity in the 1840s. During the actual famine, he points out, wealthy landowners swallowed up the smaller farms as the poor died or left. While this helped create larger, more sustainable farms, it was not a practice that benefitted the native Irish in any capacity. ${ }^{152}$

\section{The Increasingly Negative Perceptions}

As the horrific stories of the famine spread across England and the years of starvation continued unabated, English attitudes, particularly those in or near the large urban centers of immigration, began to change. The charitable desire to help the starving masses turned to frustration as the Irish flooded English cities and sapped valuable resources. The 1841 Irish census listed a total population of 8,175,124 people. By 1851 that figure had fallen to 6,515,794, a drop in total population of almost one-third and most ended up in the industrial cities of England or died. ${ }^{153}$ Just before the famine, Frederic Engels wrote The Conditions of the Working Class in England. In his analysis, the Irish became a cornerstone in the mentality of the English, as the famine continued unabated. According to Engels, these were people for whom the lowliest condition were acceptable. "The worst accommodations" were good enough and they took "no trouble with regard to their clothes which hang in tatters.” Barefoot beggars filled the streets, living only on potatoes and any money that remained "goes on drink." ${ }^{54}$ During the early years of the famine, The Times echoed Engels' perspective on their Irish neighbors. The

\footnotetext{
${ }^{152}$ ÓGráda, Ireland Before and After the Famine; ÓGráda, Black '47 and Beyond: The Great Irish Famine in History, Economy and Memory (New Jersey: Princeton University Press, 2000), 47, 54.

${ }^{153}$ Thom's Irish Almanac and Official Director of the United Kingdom, 99.

${ }^{154}$ Frederic Engels, The Conditions of the Working Class in England (Oxford: Basil Blackwell, 1958), 105.
} 
Irish "have come amongst us, but they have not become of us. "They take English money, but they remained debased" and had "neither our love of cleanliness nor our love of comfort, neither our economy nor our prudence.”155 Ireland was, according to the English press "nearly a foreign nation,” and one from which they wanted to maintain their distance. ${ }^{156}$

These mongrels were not limited to Irish soil, but came as a "swarm" to the slums of “all the big towns.” Engels reported “seeing mainly Celtic faces” in the districts noted for "filth and decay." ${ }^{157}$ With a foreshadowing of the scientific racism that would dominate the later half of the century, he stated that the Celtic faces were "quite different from those of the Anglo-Saxon population” and were most “easily recognizable.” 158 This debased population, this “ready-made nucleus of degradation and disorder," was, according to Thomas Carlyle, "holding out his hat to beg... he is the sorest evil this country has to strive with... in his rags and laughing savagery." ${ }^{159}$ Relief for Ireland was useless, even to Carlyle writing a number of years before the famine crisis, and these starving savages were now becoming a serious threat to the stability and welfare of England as well. According to The Times, the point of aid was not to "lead the Irish people on step by step.” A certain amount of hardship was necessary to “indoctrinate Ireland gradually into self-reliance” and the goal of English assistance was not intended to "leave them at the end of that time precisely in the same situation as at the

\footnotetext{
155 The Times, September 1, 1846.

${ }^{156}$ Illustrated London News, February 20, 1847.

${ }^{157}$ Engels, The Conditions of the Working Class in England, 105.

158 Ibid, 105.

159 Thomas Carlyle, Chartism, (London: James Fraser, 1840), 28.
} 
commencement” of the famine. ${ }^{160}$ Yet all accounts indicated that this was exactly what had happened.

The financial burden of the Irish poor was only the first of a two part shift in English attitudes. The second was the ever-increasing violence escalating across Ireland. As early as November of 1845, The Times issued a cautionary warning to its readers concerning their charitable donations. Rumors circulated that much of the charity leaving English pockets was headed straight into the coffers of radical groups fighting to repeal the Act of Union. ${ }^{161}$ By 1846, the media presented the arms and charity connection less as rumor and more as fact. The Times assured its readers that "a good deal of relief money and rent money goes to the armourer” as theft, vandalism and murder increased as the crisis deepened. ${ }^{162}$ In November of that year, The Times broke the scandalous story of the Irish bank accounts. Large sums of money had been deposited into accounts in banks across Ireland without explanation and The Times argued that this money had come from charitable donations and the Poor Law Relief Fund and was destined for nefarious purposes. “A few more famines,” The Times insisted, “and Ireland will become one of the wealthiest countries in the world.” ${ }^{163}$ In his history of the revolutions of 1848, author Edward Stillingfleet Cayley argued that a great part of the money given to Ireland in 1847 to prevent mass starvation had been "diverted to the purchase of arms" as newspapers under the editorship of the Young Irelanders urged the local populous to buy weapons for an "open war” on England. These arms, Cayley posited, were smuggled out

\footnotetext{
${ }^{160}$ The Times, August 26, 1847

${ }^{161}$ The Times, November 20, 1845: 4.

162 The Times, November 30, 1846: 4.

163 The Times, November 6, 1846: 4.
} 
of Liverpool and into Ireland through the devious chain of immigrants living on English soil. $^{164}$

The murder of Major Denis Mahon became a focal point of the rising tide of violence across Ireland. A prominent Anglo-Irish family, the Mahons owned a sizable holding in Stroketown, County Roscommon. On 2 November 1847, the patriarch of the family and landlord of the massive estate, Major Denis Mahon, was assassinated by several local men in response to the removal of starving tenant farmers. In 1845, he began forcing his poorest tenants into emigrating on the infamous coffin ships bound for Quebec and approximately one-third died en route. When news of the evictions and deaths reached home, his tenants revolted. His murder did not, however, halt the evictions and eventually over 11,000 tenants were removed.

In the wake of the Major's death, allegations spread through Strokestown concerning the local priest. Father McDermott had apparently used his authority as a church official to denounce Mahon from the pulpit just days before the murder. The English press immediately seized upon the information to impress upon the public that the Catholic Church was clearly supporting and agitating violent rebellion on the island. ${ }^{165}$ On the $13^{\text {th }}$ of November, The Examiner gave a full report on the murder of “this unfortunate gentleman” in its column on news from Ireland. That same column reported the murder of the widow Dermony from Tipperary, two break-ins in Limerick, the beating and robbery of Mr. Harding in Lohorne, the murder of Daniel O’Connell’s

\footnotetext{
${ }^{164}$ Edward Stillingfleet Cayley, The European Revolutions of 1848, Volume III (London: Smith, Elder \& Co., 1856), 241, 248, 256.

${ }^{165}$ Peter Duffy, The Killing of Major Denis Mahon: a mystery of Old Ireland (New York: HarpersCollins, 2007)
} 
steward Michael Walsh in Clare, and 347 criminal cases awaiting trial. ${ }^{166}$ Later that month, the newspaper published the continued "atrocious spirit of murder and violence" in County Tipperary, including the murder of a land-agent and his brother-in-law, the cold-blooded shooting of a man and wife. ${ }^{167}$ Punch published the scathing satire entitled “Irish Game Laws: Landlord Shooting Begins 1 January” and announced that Christmas Day of 1848 was "kept a complete holiday throughout all of Ireland... not even a single landlord was shot.”168

One month after the assassination, the House of Lords discussed Father McDermott's denunciation and the language of hate and anger from both the priest and the local people. The Examiner reported that the House of Lords agreed that there had been a "conspiracy against his life" from the entire town. ${ }^{169}$ The Examiner argued that “vigorous measures" were needed to "restrain and punish Irish crime" in the wake of the murder. Authorities needed to "make an example of the tenantry" as they had protected the murderers from the "clutches of the law." 170 They needed to be "swept from the land" because “expulsion is the lot of Cain.”"171 Mahon’s murder even caught the attention of the royal family, prompting Queen Victoria to complain in her diary that the Irish "really ... are a terrible people." She pointed out that the more England seemed to do, the "more unruly and ungrateful they seem to be.”172 Author George Lewis Smith argued that while there were perhaps mitigating circumstances in the Mahon murder, the murder of Lord

\footnotetext{
166 The Examiner, “Ireland,” 2076, November 13, 1847: 728.

167 The Examiner, “Ireland,” 2077, November 20, 1847: 743.

${ }^{168}$ Punch, 14 (January-June), 1848, 29; Punch Volume XIV, (London: The Office, 1848), 5.

169 The Examiner, "House of Lords,” 2080, 11 December 11, 1848: 790.

170 The Examiner, “Crime In Ireland,” 2076, November 13, 1847: 721; Fraser's Magazine for Town and Country, “What Will the Government Do?” 36:216 (December, 1847): 745. (743-749)

${ }^{171}$ The Examiner, “Crime In Ireland,” 2076, November 13, 1847: 721

172 Queen Victoria quoted in Christopher Hibbert, Queen Victoria: A Personal History (New York: De Capo Press, 2001), 438.
} 
Norbury illustrated the true violent nature of the Irish. Norbury was a "mild and humane man” who treated his tenants fairly, but was nonetheless gunned down after removing a man from his property. The act was all the more savage according to Smith, because Norbury had compensated the man quite well for his time and trouble caused by the eviction. ${ }^{173}$ Parliament was so concerned they established a Special Commission on Irish Crime assigned to investigate the rising criminal activity across the Irish Sea. Even The Economist, usually focused solely on the financial aspect of the famine began to shift its coverage of Ireland. In September of 1847, an article on the Irish Coercion Bill described the "lawless atrocities" so common in the "turbulent race" who show no interest in social order or structure. ${ }^{174}$ The island was developing a "dark reputation for deeds of sinister violence and heartless bloodshed,” and the English needed to harden their hearts against such activities and the people engaged in them. ${ }^{175}$

\section{Fear of Rebellion}

By 1848, the press issued dire warnings that the Irish Confederates were “endeavoring to organize the Irish, who are either settled or are vagrant in England” in order to "create a diversion” in their continued "conspiracy against the peace” of England and the empire, thus diverting attention from the crisis of famine in Ireland to the crisis of potential violence on English shores. ${ }^{176}$ The press reflected the growing anger with Ireland and argued that "if they will not learn, before rebellion, the notorious fact that Irishmen have every privilege which Englishmen have, except the unhappy privilege of being taxed," they need to "pay for the penalty of their ignorance” with the end of aid,

\footnotetext{
${ }^{173}$ George Lewis Smith, Ireland: Historical and Statistical (London: Whittaker \& Co., 1849), 56.

174 “The Irish Coercion Bill,” The Economist Issue 225, December 18, 1847: 1445.

${ }_{175}$ George Lewis Smith, Ireland: Historical and Statistical (London: Whittaker \& Co., 1849), 54.

${ }^{176}$ Weekly Dispatch, April 2, 1848.
} 
charity, and benevolence from the English public. The English people, according to the press, poured over $£ 8$ million into Ireland and have been repaid in "8 million curses."177 While England contributed its hard-earned taxes to famine relief, the rebellious Irish contributed "seditious harangues, inflammatory appeals to the passions" and blatant “misrepresentations of the contributions and motives of the British people." ${ }^{178}$ According to The Times, the only agenda of the rebellious Irish traitors was "love of each other and... hate [of] the English,” and their only response to England was that of violence. ${ }^{179}$

The political arm of these Irish confederates was known as the Young Ireland Movement. These upstarts were literary intellectuals associated with The Nation newspaper, launched in October of 1842. They were initially a faction of O’Connell’s Repeal movement, but the famine drove a deep wedge between the younger generation and the old guard. They challenged O’Connell's authority and his dominate presence among the Irish representatives. This younger generation also believed that divisions between Catholics and Protestants were weakening Ireland's position against England, and they disagreed with O'Connell's continued insistence on tying the repeal of the Act of Union to Catholic interests. The final break came when O’Connell considered suspending the demand for repeal in order to develop a political alliance with the Liberals against the Conservative faction of Parliament. In order to quell the increasingly aggressive language of the Young Ireland members, O’Connell insisted the Repeal movement adopt resolutions condemning the use of violence under any circumstances. Outraged simply over the insinuation of aggression on their part, a number of younger

\footnotetext{
177 Illustrated London News, 12, 15 April 15, 1848: 244.

${ }^{178}$ The Annual Register, or a view of the History and Politics of the year 1848 (London: F \& J Rivington, 1849), 100.

${ }^{179}$ The Times, November 14, 1846.
} 
nationalists broke from O’Connell’s Repeal Association and established the Irish Confederation in the spirit of the growing liberal revolutionary movements. ${ }^{180}$ At its founding, the Confederation based itself on the principles of freedom, tolerance and truth. While the young men did not directly call for rebellion, they refused to make an absolute pledge for maintaining peace either. Their goal was independence of the Irish nation and they held to any means to achieve that which were consistent with honor, morality and reason. $^{181}$

To the English, the Repealers had now split into "those who were for moral, and those who were for physical force,” similar phrases aimed at the split between the Northern Chartists and the Southern Chartists in relation to violence and aggression. ${ }^{182}$ The Young Irelanders were seen as a serious threat as they encouraged the collection of weapons and military style drilling among the general populous. They were the "physical force men” in the guise of politicians encouraging the "agrarian outrages" across Ireland and they represented the intensely nationalist fanatic strain in the Irish people. ${ }^{183}$

Although they called themselves politicians, the press argued that Young Ireland was actually "bent on war” against England by inciting the local populous to violence. ${ }^{184}$ Activities in Ireland did nothing but heighten the rising fear of revolution, and in 1848 those fears were confirmed. The language of violence intensified as the United Irishman demanded that "above all, let the man amongst you who has no gun, sell his garment, and

\footnotetext{
${ }^{180}$ S. J. Connolly, “The Great Famine and Irish Politics,” in The Great Irish Famine, ed. Cathal Póirtéir (Dublin: Mercier Press, 1995,) 42-43.

${ }^{181}$ Michael Doheny, The Felon's Track (London: M.H. Gill and Sons, 1951), 112.

${ }^{182}$ George Lewis Smith, Ireland: Historical and Statistical (London: Whittaker \& Co., 1849), 460.

183 Cayley, The European Revolutions of 1848, 139.

${ }^{184}$ W.F. Collier, History of the British Empire, (London: T. Nelson and Sons, 1859), 324.
} 
buy one." ${ }^{185}$ The angry rhetoric was becoming a direct call for revolution as the famine bit deeper and deeper into the Irish countryside. By the summer of 1848, tension was running high in Ireland amidst the general atmosphere of revolution spreading across Europe. In February of that year, King Louis-Philippe of France was overthrown and the Second Republic was proclaimed in Paris. Subsequent revolutions broke out in Berlin, Vienna, Rome, Prague, and Budapest and liberal governments were temporarily established in many of the European nations. In 1848, open rebellion broke out in Ireland. From the 23rd to the 29th of July, William Smith O'Brien and several other Young Ireland leaders raised the standard of revolt as they travelled from County Wexford through County Kilkenny and into County Tipperary. Supporters of the revolt erected barricades in the town of Callan and the police issued arrest warrants for everyone involved. As the police approached the town, they saw barricades in front of them and veered up the road toward County Kilkenny. The rebels followed them across the fields. Sub-Inspector Trant and his 46 policemen took refuge in a large two-story farmhouse, with five young children still in the house. They barricaded themselves in and the house was surrounded by the rebels. A stand-off ensued and finally, Mrs. Margaret McCormack, the owner of the house and mother of the children, demanded to be let into her own home. The police refused and would not release the children. O'Brien and Mrs. McCormack went to the window to negotiate. Confusion broke out and general firing ensued between the police and the rebels. The shooting went on for a number of hours and Irish rebels Thomas Walsh and Patrick McBride were shot dead in the volley.

\footnotetext{
${ }^{185}$ United Irishman, 4 March 1848, pg. 56; For secondary analysis on the Irish nationalists and revolution see: John Belchem, "Republican spirit and military science: the 'Irish brigade' and Irish-American nationalism in 1848," Irish Historical Studies, 24, May (1994) and Belcham, "Nationalism, republicanism and exile: Irish emigrants and the revolutions of 1848," in Past and Present, 146, Feb. (1995).
} 
Reinforcements from the Cashel police sub-division arrived and the rebellion was finally quelled.

The reaction from the English press was mixed in its interpretation of the uprising. Some simply called it an "explosion of Irish folly" and an "utter failure of a rebellion” spurred by the arrogance of youth. ${ }^{186}$ Others viewed it as “very threatening,” calling the O’Brien rebellion a “conspiracy... magnified by the vanity of a few conceited demagogues.”187

There were dissenting voices during this tumultuous period. In the midst of these rebellions in 1847, James Tuke, an English businessman and philanthropist, spent a number of months in Connaught. His letter to a Quaker relief organization was published as A Visit to Connaught in the Autumn of 1847. It created a firestorm of controversy. Removed from circulation for a month, Westminster was troubled by Tuke's position on the uprisings. He first charged that Ireland was being summarily dismissed and accused without looking at it “in its separate parts,” meaning regionally. ${ }^{188}$ Local violence was, he argued, being applied nationally and this was unacceptable as most of Ireland was a lawabiding nation. He also charged the English with blatant hypocrisy. He pointed out that the English complain bitterly when the Irish migrate, but the "usual charge of helplessness" is applied when they "quietly remain in Ireland” to starve to death. ${ }^{189}$ The largest portion of his letter was aimed at the wretched mismanagement and abuse of the landlords. Like Mill and Foster, he believed that Ireland could and should be self-

\footnotetext{
${ }^{186}$ Cayley, The European Revolutions of 1848, 274.

187 The Annual Register, or a view of the History and Politics of the year 1848 (London: F \& J Rivington, 1849), 95.

188 James Tuke, A Visit To Connaught in the Autumn of 1847: A Letter addressed to the Central Relief Committee of the Society of Friends, Dublin, Second Edition (London: C. Gilpin, 1848), 4.

${ }^{189}$ Ibid, 7.
} 
sustaining. Echoing O’Connell's early fears on the Poor Laws, he pointed out their utter failure because landlords refused to pay their taxes and the native population was simply too poor to tax at all. The fault for the crisis and its ensuing rebellion did not rest with the Irish, but with the landlords and land legislation. His attacks on the landlords were not framed in the evil landlord/ good tenant dichotomy. He recognized the right to evict tenants, but he stressed, there had to be a viable rationale for doing so. Landlords were “morally liable” for their tenants and must consider their actions carefully. ${ }^{190}$ His discourse on the changes and improvement that landlords could make was not vitriolic, but logical and reasonable. His descriptions of the workhouses and the poverty were not simply emotional appeals. He provided statistical evidence as to the percentage of land use, wages, poor house funding and other financial information on the wealth gap in Ireland. ${ }^{191}$ He also suggested the cultivation of native industries, such as fisheries, to provide employment. ${ }^{192}$ This letter was so controversial during this tense year that it provoked Parliament into an investigation of the landlord abuses and evictions. ${ }^{193}$

In spite of its immediate impact, Tuke’s dissent and others like him could not sway the larger public opinion. The investigation into abuses, prompted by Tuke’s letter, was dropped with no specific reason given. 1847 and 1848 were watershed years for the shift in public attitudes toward the Irish. Tension had been building for several decades, dating back to the early immigration of the 1820s, the Chartist Movement of the 1830s and 1840s, and the Great Famine. The violence at the end of the decade seemed a culmination of all of these problems brewing between the two nations.

\footnotetext{
190 Ibid, 23-25.

191 Ibid, 17-22.

192 Ibid, 32.

193 The Times, February 12, 1848.
} 
Throughout the 1840s, debates in Parliament shifted from the famine crisis to the growing issues of crime and violence. Criminal activity in Ireland was raised over 900 times from 1840 to 1849 in the House of Commons. ${ }^{194}$ The fear of revolution permeated the social and political landscape of Europe. The English, in contrast to their violent neighbors, were "wholly unfit for conspiracies and revolutions” as they valued law and order and maintained a respect for the institutions of government. Revolution was distasteful and the Irish disturbances were becoming wearisome. The July rebellion had "disgusted even the most tolerant friends" of Ireland and by the close of 1848, the public was simply “disgusted by Irish ingratitude.” 195 The Examiner argued that all current measures had failed to suppress rebellion and the situation in Ireland was so bad that the suspension of Habeas Corpus was the "only measure adequate to the crisis" at hand and MP Lord Glengall, arguing before Parliament, agreed. ${ }^{196}$ He too stressed the vital importance of suspending Habeas Corpus to "prevent anarchy and insurrection." ${ }^{197}$ In a satirical show of support for the suspension, Punch published a dialogue between English representative John Bull and French representative Johnny Crapaud over the issue of revolution. Crapaud asks Bull, “Will it not tempt you?” to which Bull replied, “we don’t allow our rabble to kick up a row."198 According to The Economist, The Earl of Clarendon was trying to teach the Irish their "moral duties" by "setting them an example by his conduct of that calmness, simplicity, moderation, and truth telling which they so

\footnotetext{
${ }^{194}$ Accessed September 12, 2010. http://hansard.millbanksystems.com/search/crime\%20Ireland?decade=1840s

${ }^{195}$ The Annual Register, or a view of the History and Politics of the year 1848, (London: F \& J Rivington, 1849), 96; Cayley, The European Revolutions of 1848, 202, 226.

196 The Examiner, 2076, November 13, 1847: 728.

${ }^{197}$ Lord Glengall quoted in The Annual Register, 97.

198 “John Bull and Johnny Crapaud: A Dialogue,” Punch Volume VIV, (London, The Office, 1848), 235.
} 
much require to make them perfect” and they consistently rejected any attempt at this offer of civilization. ${ }^{199}$

Not all opinions were, of course, so harsh. Initially, the English press, while hardly enlightened, did focus a significant amount of attention on the sufferings of the Irish and reflected a genuine desire to ameliorate them. During this same period, the Chartists were forging an alliance with the Irish nationalists as outlined in Chapter Two. Sherrif and Mill were arguing for public works and "real” relief for Ireland instead of pure charity. Factions of the population of England were indeed supportive of the Irish. The zeitgeist for the middle class was growing cold however. It was not entirely negative as Mill, Foster and others continued to present nuanced arguments in favor of Ireland and its people. The problems of prior decades were simply beginning to wear on the people as Soss and Scharam argue is inevitable.

As the famine wore on this weariness became more evident. In 1841, the population of Ireland was $8,196,597$ and by 1851 , the total population had fallen to 6,574 , 278. Conversely, England's population in 1841 was 16,035,198 and by 1851, it had risen to $18,054,170 .^{200}$ The Irish were teeming into England by the thousands, and Engels, Carlyle and others had painted a picture of an invading human plague rather than the charitable suffering lot from across the seas. This growing negative perception, fuelled by the ever increasing immigration problem, translated into a general dislike for the Irish as a race and included those that remained in Ireland as well as those abroad.

\footnotetext{
199 “Ireland.-A Model State Paper,” The Economist Issue 218 (October 30, 1847): 1244. (1243-1244).

200 Thom's Statistics of Great Britain and Ireland (Dublin: Alexander Thorn, 1868), 80, 1.
} 


\section{Genetics, Religion and Degradation}

This perspective was framed by a view of the Irish people that emphasized the permanence of their character and condition. Their misfortunes were no longer seen as the product of past mistakes or random happenstance, but were rather in the nature and destiny of the Irish themselves. The failure of what was assumed to have been the great experiment of liberal free trade and equal access to the political process during the early years of the famine under the Peel administration had demonstrated the futility in attempting to raise them to an English standard of civilization. In 1798, during the debates on the Act of Union, some philanthropists in England believed that by familiarizing the Irish with the "habits of industry and commerce... and by adopting English manners," this lower order would be "humanized." ${ }^{201}$ By 1848, however, there was a more sinister tone surrounding the Irish that focused on the 'real' cause of the suffering of this insufferable group of "bogtrotters." 202 The real source of the trouble was not crop failure, but the neglect of agriculture "for the more agreeable and gainful trade of agitation and assassination” and Ireland was wasted not by a blight, but by the "protracted reign of terror" thus making many parts of the country "incapable of bearing grain crops. ${ }^{203}$ These insinuations of violence were similar to the charges leveled by the popular press against Feargus O’Conner and his physical force ruffians in the Chartist movement.

Some factions of English society began to attribute the famine in part to Catholicism and the Irish inability to be enlightened along English spiritual lines. To

\footnotetext{
${ }^{201}$ The Times, December 5, 1798.

202 The Times, September 18, 1846: 4.

203 “Continental Revolutions-Irish Rebellion-English Distress,” Blackwood's Edinburgh Magazine, 64 (October, 1848): 487.
} 
many middle class English, Ireland's degradation and impoverished state could not be separated from its "corrupted faith." ${ }^{204}$ An editorial in The Times of London argued that the "demagogue and the priest will deliberately stand between English charity and Celtic

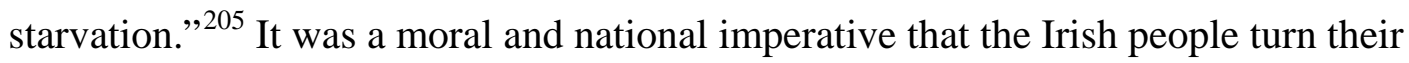
backs on their faith and accept the only true form of Christianity in order to find salvation from both damnation and starvation. Thomas Carlyle fervently believed that the only way to save the Irish from mass starvation and devastating poverty was for them to "cease generally from following the devil” of the Pope and the priests of Catholicism. ${ }^{206}$ The Church of England's more radical ministers put forth the notion that the famine was not a lesson for humanity on the virtues of charity, but was instead God's wrath against the “impenitent” Catholics of Ireland. ${ }^{207}$ Only the "pure form of Christianity,” the Protestant faith of England, could save the vanquished souls of Ireland from the depths of starvation and damnation. ${ }^{208}$

Reports even began to challenge the very notion of the Famine itself. Questions began to surface concerning the real state of Ireland and the extent to which things might have been exaggerated in order to drain the English coffers. As early as 1846, the Chairman Commissioner of the Irish Public Works Board, Lieutenant-Colonel Jones directly refuted the claims of mass crop failure on the island. He witnessed a man digging potatoes, and according to his statement, "the crop looked good... about one-half were sound.” He stressed that "there is much more food of that description than the general

\footnotetext{
${ }^{204}$ Massy, Analytical Ethnology 2175.

205 "Editorial," The Times October 18, 1845.

${ }^{206}$ Carlyle, Reminiscences of My Irish Journey in 1849, 223.

207 "Minister of the Gospel," The True Source and End of Ireland's Destitution; together with an Appeal, to British Christians, on Behalf of Ireland (London: John Snow, 1849), 10.

${ }^{208}$ Massy, Analytical Ethnology, 79.
} 
outcry about famine would lead strangers to believe.” He also pointed out that although the fields were full of wheat, there were "no signs of threshing” whatsoever, and "no signs of farm labour." The local drainage operation could not fill its positions as the "men had refused to work."209 Author George Lewis Smith reflected on the fact that there was a "great portion of land” across Ireland "wanting labor” and therefore it could only mean the Irish did not want to work. ${ }^{210}$ These arguments clearly indicated that the famine was by no means as bad as the foreign press indicated, and the Irish themselves were to blame as, like many English were beginning to believe, the people were simply lazy and wanted to live off the backs of English charity. In 1847, The Aberdeen Journal supported Jones’ claim in an article about the supposed devastation. The newspaper reported that claims surrounding the return of the blight "have been contradicted" and the "crops still look beautifully.”211 The English people were being duped into providing relief for a group of people unwilling to work in their own country and depriving hardworking English laborers out of employment in their own country.

The English were frustrated and tired of what they perceived as the ever growing burden of the Irish people, both in Ireland and as immigrants to English shores. In a critical analysis of the effectiveness of the Poor Laws, one anonymous commissioner argued that historians attributed the decline of the Roman Empire to the mass distribution of corn from the public granaries and government controlled prices on corn in order to feed the poor. This relief across the Empire increased taxes on the middle classes who were destroyed under the ever increasing burden. He likened the situation to Parliament

\footnotetext{
${ }^{209}$ Lieutenant-Colonel Jones, Correspondence From July, 1846, to January, 1847, Relating to the Measures adopted for the Relief of the Distress in Ireland. Board of Works Series (London, William Clowes and Sons, 1847), 137.

${ }^{210}$ George Lewis Smith, Ireland: Historical and Statistical (London: Whittaker \& Co., 1849), 28.

211 “Ireland,” The Aberdeen Journal, 5187, June 9, 1847; The Nation, July 12, 1845.
} 
maintaining strict control over wheat prices in order to subsidize Poor Laws as the number of paupers continued to escalate in the wake of the Irish famine. ${ }^{212}$ His veiled threat on the decline of empires was echoed in the popular media as immigration into the major urban centers of England continued seemingly unabated.

By the late 1840s, English public opinion on Ireland was tumultuous and complicated. Diarist and political insider Charles Greville wrote that the people were “animated by very mixed and varying feelings... and are tossed about between indignation, resentment, rage, and economical fear on the one hand, and pity and generosity on the other.”213 John Stuart Mill argued that Ireland needed and deserved real relief effort, yet he acknowledged the Irish people’s lack of civilization. Thomas Carlyle railed and ranted against them. Daniel O’Conner spoke eloquently on the plight of his people while MP Lord Glengall demanded stiff retribution for Irish violence. Like O’Connell, William Smith O’Brien spoke passionately about labor problems in both England and Ireland in the early 1840s, but by the late 1840s he was leading violent rebellions against the crown. The landlords were abusive, but the tenants were violent and feckless. Which side was correct? Why was relief having no impact? Why were the Irish still starving? Who was to blame- the Irish people or Parliament? These were questions without clear answers for the English middle class, but they were simply getting tired of asking.

The famine wreaked havoc across Ireland and the total losses from death and immigration are argued to this day. The devastating consequences to the native population could not be overlooked, but neither could the ever increasing burdens and

\footnotetext{
${ }^{212}$ Great Britain, The Poor Law Commission (London: G. Luxford, 1846), 11.

${ }^{213}$ Charles Greville, The Greville Memoirs: Volume II (New York, D. Appelton, 1885), 216.
} 
conflicts. While the English started out the century with a condescending benevolence toward their neighbor, the years took their toll on that good will. The middle class ratepayers saw their tax relief vanish into the morass of Irish problems year after year with little to show after a decade of support. Reports from Ireland became more negative in tone as the starving population was "disgustingly dirty" with "squalid, pale countenances, the very reverse of pretty." The Irish wore "hollow-cheeked, pallow, miserable" aspects that made the living look as if they were already in the "after-life," thus creating a distasteful presence. ${ }^{214}$ In 1848, Punch ran a biting satirical article on new definitions for an Irish dictionary. The United Irishmen were defined as "natives of Ireland, who were always quarrelling with each other, and everyone else.” A confederate was a member of a political party "bent on dissolving all existing ties between Ireland and the rest of the world.” A Saxon was defined as "every one who receives rent from land, follows an honest calling, keeps a civil tongue in his head, a whole coat on his back.” Saxon aggression meant "paying for Irish debts out of English pockets, feeding Irish famine with English subscriptions and supporting Irish labour out of English wages” and fraternity to an Irishman meant "encouraging men to cut each other’s throats." Demands for repeal of the Union came from "a people without occupation, leaders without honesty, labour without capital, turbulence without control, [and] wit without common sense.”215 Seeped in ingratitude, these were the same people flooding into England bringing disease, overcrowding, crime, and immense poverty to English shores. They were in effect, destroying England as they had destroyed their own country.

\footnotetext{
${ }^{214}$ Theresa Cornwallis I. Whitby West, A Summer Visit to Ireland in 1846 (London: R. Bentley, 1847), 5, 47.

215 “English Definitions, For an Irish Dictionary,” Punch: Volumes 14-15 (London: The Office, 1848), 214.
} 


\section{Chapter Four}

\section{Immigration}

Throughout the 1840s, anger and frustration toward the Irish continued to escalate among the middle class of England. Not only were they stirring up trouble in the industrial centers with the Chartist movement, but the financial drain from the Great Famine was becoming a burden the English no longer wanted to carry. The years of starvation, however, added another powerful factor to the 'Irish problem' as thousands of paupers fled the devastation in Ireland and added to the numbers already in England from prior decades. Although Irish poverty had been a growing concern in the major metropolitan areas of England for decades, the image of Ireland's wretchedness became less a thing of pity and more a source of hatred as they brought their degradation to English cities in the 1850s. For as long as the Irish remained largely in Ireland, they were a distant problem to face. Charity and aid could be sent across the seas to a people seen as foreign in spite of their political and economic connections to England. As the famine became an entrenched facet of life in Ireland and the immigrants began to flee in record numbers, the 'other' was no longer a distant problem. His poverty, disease, and savageness had, as Thomas Carlyle warned years before the height of the famine, invaded the English body. The 1850s were marked by several distinct trends in Anglo-Irish relations that laid the foundation of anti-Irish prejudice that would later be justified through scientific racial theories in the later decades of the 1800s. First, the sheer number of immigrants increased dramatically in the late 1840s, creating very real problems in the industrial centers. Second, the horrors of the ghettos, as highlighted by reports and publications throughout the 1830s, became an ever increasing problem as the numbers of 
Irish continued to swell. Lastly, this massive influx of poor Irish led to an intense fear of the other invading England and the possible changes that this other could bring to English society.

\section{The Historiography of Immigration}

Like the literature on the Great Famine, the history of immigration has been rife with nationalism and binaries. Immigration cannot be divorced from the Great Famine and it has, therefore, been a tool for political voices on both sides of the nationalist debate. Religious binaries have also been a convenient tool for eradicating the nuances of immigration. Early historians tended to view the Irish immigrants as a homogenous, Catholic body moving out of Ireland. More recent trends paint a more nuanced picture through a closer examination of the Irish themselves to regional analyses of the areas in which they settled.

Kerby Miller’s 1988 work Emigrants and Exiles: Ireland and the Irish Exodus to North America is an outstanding example of post-IRA emigration analysis free from troubling nationalist edges. As the first transatlantic analysis of the Irish, Miller argues that on both sides of the Atlantic, emigration was viewed quite negatively. It was not an opportunity for self-improvement, wealth, or land. The Irish instead saw it as exile and banishment from their homeland. They were thousands of miles from family, community and Irish culture and politics. Many were even isolated religiously as they settled in communities with strong Protestant traditions.

A unique facet to Miller's argument rests not in the view from the Irish themselves, but also in the view from those who benefited from their departure. In the second portion of his work, Miller outlines the position of the Irish commercial farmer. 
This was a new class of Irishman with larger land holdings as a direct result of the Famine. They too, Miller posits, believed emigration was not voluntary, but a form of forced exile. He points out that this was a very convenient argument as it ignored the growing practices of eviction, enclosure, and marker-oriented farming that was becoming the backbone of their wealth. ${ }^{1}$ Miller's thesis does not demonize the English nor does it position the Irish as victims. His position of the Irish as a premodern culture is quite dated two decades later. Many critics also argue that he paints the Irish community as a global entity in broad strokes without considering local and regional variations. While these critiques are all quite valid, his work is still an excellent early examination of the phenomenon of Irish emigration and the attitudes behind it.

Robert Scally’s 1995 work The end of Hidden Ireland: rebellion, famine, and emigration was published amidst the sesquicentenary of the Irish famine. It was one of the earliest works to trace not only the famine itself, but to link the disaster to the subsequent impact of the transatlantic exodus. His focus centers on the resilient, deeply alienated rural community of Ballykilcline, County Roscommon. He argues these people were 'hidden' from the larger socio-political structure prior to the Famine. He positions the natives as naïve to the complex system of land ownership and when the Crown attempted to modernize the rent collection system, they resisted. Their struggles with rent strikes and the disastrous management of the Mahon estate went unnoticed to anyone outside the area as the decades wore on. This changed, however, as the famine worsened, tenant evictions began in record numbers and Major Mahon was murdered.

\footnotetext{
${ }^{1}$ Kerby Miller, Emigrants and Exiles: Ireland and the Irish Exodus to North America (Oxford: Oxford University Press, 1988), 345-492.
} 
The second portion of his book takes the themes he outlined locally and applies them to emigration across Ireland. His argument rests in the premise that the "townland of Ballykilcline” basically “corresponds to the general pattern of famine emigration.”2 This thesis is built upon the older, more nationalistic scholarship of the 1970s IRA influenced period. His broad theme focuses on Ballykilcline as a town fighting against the "intrusion" of the oppressive "colonizer." 3 This region, he argues, was making a valiant attempt to withstand encroaching modernization and under the yoke of the state, they had become a subjugated peasantry. He posits that emigration was forced upon the native population as a state solution to the Famine. Those selected for removal entrenched themselves in Liverpool in what Scally believes was a concerted effort to resist further government control. While this work is important because it was among the first to broaden the scope of the famine to include a direct analysis of emigration as well, it nonetheless remains too closely linked with the emotionally charged scholarship of prior decades.

Donald M. MacRaild’s 1999 work Irish Migrants in Modern Britain examines the traditional themes of immigration, including the influences within Ireland due to migration to England and the culture of the Irish communities abroad, but he also places the Irish immigrants with the wider context of the Irish Diaspora. Like scholars of previous generations, he emphasizes the adverse and often violent reaction to the Irish as they settled abroad, but he provides more thought-provoking depth by including a chapter on the Irish Protestant immigrant community. MacRaild argues that those fleeing the famine were not all Catholic and this creates a more diverse range of experiences that

\footnotetext{
${ }^{2}$ Robert Scally, The end of hidden Ireland: rebellion, famine, and emigration (Oxford: Oxford University Press, 1995), 3, 124-125.

${ }^{3}$ Ibid, 232-233.
} 
must be considered. He acknowledges that while the majority was Catholic, this small group of Protestants lends a new voice to the immigrant experience in the mid-1800s. They were Irish, and therefore experienced much of the prejudice of the period, but they worshipped the English version of God and so could not be clearly defined as the other in Victorian society. His work still focuses heavily on the anti-Irish sentiment, and thus the Irish Protestants get a bit lost amidst the labor politics, Catholic cultural clashes and social bonds. They are, nonetheless, a presence that adds greater complexity to the immigration narrative.

In 2000, J. Matthew Gallman released his work Receiving Erin’s Children: Philadelphia, Liverpool, and the Irish Famine Migration, 1845-1855. Gallman's work is unique in that the Irish immigrants are not central to the narrative. Instead, the two cities in his title, Philadelphia and Liverpool, play center stage as he used immigration as framework for the analysis of policy. Gallman’s arguments stem from a critical question surrounding immigration in the mid-1800s. Were the Irish the impetus for reform or were changes already underway? If change was already occurring, Gallman posits, then the Irish issues were not singular, but were instead part of a larger struggle with growth, industrial development and urbanization on both sides of the Atlantic.

Gallman states that during the Victorian period, local and national governments were forced to face a "variety of social ills, particularly those affecting the materially disadvantaged.” ${ }^{4}$ He recognizes that the crisis in Ireland meant that a considerable portion of those "disadvantaged" were Irish as the famine sent millions to foreign shores in a short period of time. Essentially, the other had arrived en masse. The sheer number

\footnotetext{
${ }^{4}$ J. Matthew Gallman, Receiving Erin's Children: Philadelphia, Liverpool, and the Irish Famine, 18451855 (Chapel Hill: University of North Carolina Press, 2000), ix.
} 
of Irish helped to define a common demographic in both cities and provides an excellent point of comparison. Both cities, he posits, held similar views of land ownership, enterprise, poverty and its relationship to personal worthiness, and disease. With the common demographic of the Irish, Gallman then charts the changing policies in both urban areas.

He points out that while both cities responded with similar policies toward the Irish, unique cultural aspects of each region played a significant role in the details of those policies. Philadelphia, for instance, relied more on localism and volunteerism, such as the Quakers, to address urban issues than did Liverpool. Philadelphia also had a far greater sense of optimism toward its immigrant population because with the vast tracts of North American land, these problematic people could simply be shipped west. Liverpool was, on the other hand, under a parliamentary system, and looked to the national government for legislation and initiatives on issues such as public health and safety.

In using a direct comparison method, Gallman provides a trans-Atlantic examination of immigration that offers extensive insight into the Irish in England. His brief, but illuminating observations on the ethnic and sectarian conflict is particularly important. He argues that this conflict was quickly absorbed into the existing English political system as it had been a feature of Anglo-Irish relations for centuries. In the United States, however, it disrupted the political process and was not fostered in the popular press or on the streets of Philadelphia. He also points out the small, but powerful difference in the tax issues concerning relief to the poor. In Liverpool, although most brand new immigrants did not have full access to public support under the Poor Laws, they were nonetheless eligible for short term relief. There was no such system in place in 
Philadelphia. This increased the tax burden on the people of Liverpool, a city already a stone's throw from the disaster. These distinctions set a different socio-political framework for the Irish in England than in the United States and provide further depth in the study of this immigrant group within English borders.

Like Gallman, Kevin Kenny offers a portrait of the Irish Diaspora in his 2003 article "Diaspora and Comparison: The Global Irish as a Case Study.” He posits that the Irish, because of their considerable numbers, provide an excellent migrant group in which to analyze American immigrant history as a whole. This group is distinctive because emigration as a "proportion of population” was higher in Ireland than any other country of Europe at the time. Ireland also experienced a sustained period of depopulation, unlike the sporadic immigration from other countries. ${ }^{5}$ The sheer quantity meant that sizable Irish communities developed in England, the United States, Canada, Australia, New Zealand, Latin America and South Africa. These communities, Kenny argues, form a global cultural Irish network with common characteristics that provide a basis for comparison like few other groups.

Kenny posits that scholars are still struggling to answer the critiques to Miller's 1988 work. The term Diaspora has now become a contentious one as immigration is now a global phenomenon. What defines a Diaspora? How many generations must pass before a people are no longer tied to a 'native' country? Kenny points out the broad use of the term to describe labor diasporas, trade diasporas, cultural diasporas that are distinct from national ones, and what he terms “victim” diasporas. ${ }^{6}$ These difficult questions and

\footnotetext{
${ }^{5}$ Kevin Kenny, "Diaspora and Comparison: The Global Irish as a Case Study,” The Journal of American History, Vol. 90, No. 1 (June, 2003): 135.

${ }^{6}$ Ibid, 142.
} 
varied terms muddy the waters in analyzing a specific people and their communities across the globe.

The answer, Kenny believes, rests with the nation-state. He argues that every immigrant settled into a viable nation-state somewhere around the world. That nationstate may have been a part of a larger empire, such as Canada, or a single nation such as the United States. No matter what the status, each of these nation-states had a unique socio-political framework. The emigration narrative, therefore, must be examined from within the unique framework of the individual nation-state. As Gallman pointed out, the Irish experience in Liverpool was different from that in Philadelphia because the nationstate itself was different. Immigration was not, Kenny argues, a simple process of arrival and assimilation over generations. It was an experience shaped and molded by the larger context. He emphasizes the patterns of migration as a tool for scholarly research. The Irish, for example, settled more rapidly in Britain than Australia. This created a very different climate as English response needed to be more immediate. He cites the American example of Butte Montana where the Irish were economically successful because they were among the first settlers to the area. ${ }^{7}$ This contrasts sharply to the grim narrative of poverty in the English industrial centers that continued from generation to generation. Using this approach, Kenny believes that scholars can create a more nuanced perspective on the Irish Diaspora. Individual analyzes of nation-states will create a tapestry of narratives that can collectively become the larger narrative.

Historians have followed this trend toward greater specificity in recent years. In 2006 for example, Nicholas Woodward published an article titled "Transportation Convictions during the Great Irish Famine.” His controversial thesis seeks to explain the

${ }^{7}$ Ibid, 151. 
sharp increase in crime during the Famine years. While acknowledging that poverty and starvation are logical forces behind crime, he argues that this increase can also be attributed to the possibility of opportunity. Unlike Miller, Woodward believes emigration was not entirely viewed as exile and the 'streets paved with gold' image of far-flung nations had a powerful appeal. Young men in particular, were drawn to the outer regions of the Empire and the United States. There was no work at home, starvation was rampant and they looked to foreign shores. Crime became their means of escape not through the dream of the 'big score' to pay for transport, but for the transport itself. Punishments in the pre-famine years were stiff and often included banishment on a transport ship to Australia and other distant ports. Using transportation data, Woodward argues that crime did indeed increase sharply and the locus of this crime was often in those regions hardest hit by famine. Transportation instead of hard labor served two purposes. It rid Ireland of one more starving individual and saved the state money on imprisonment. For the criminal, he was now in a position to better himself and take advantage of the opportunities a new country could offer.

This historiography is far from complete, but it provides a broad overview of the trends of the last two decades. As with other areas of Irish history, scholars are beginning to place Irish immigration within the greater context of the British Empire as a whole. Each nation-state is unique, as Kenny argues, and there is no longer an "Irish experience,” but instead each community across the globe needs examined as a unique entity as well. Historians are also making greater connections between the Great Famine and the exodus that occurred not only during, but also after, 1845 through 1855 . These new trends provide a more nuanced analysis of Irish identity and offer complex 
comparisons between communities, such as Gallman's contrasting analysis of Philadelphia and Liverpool. ${ }^{8}$

\section{Waves of Immigration During the Famine}

Once the famine struck in full force, immigration into England escalated. In 1841, the population of Ireland was 8,175,794 people and a decade later it was just over 6.5 million, a decrease of one-fifth. The population of England during that period increased by just over two million people. ${ }^{9}$ Census records indicate that the total population of England from 1821 to 1861 increased by just over eight million, a figure equal to the entire population of Ireland as of the 1841 census. ${ }^{10}$ In 1847 , at least 215,444 persons emigrated from Ireland, double the number from the previous year. ${ }^{11}$ Dock records for Liverpool, the largest seaport in the British possessions and the shipping lane that historian Frank Neal called the "maritime motorway," reflect the massive wave of immigrants entering the country. ${ }^{12}$ From January $13^{\text {th }}$ to February $16^{\text {th }}$ of 1847 , over 30,000 Irish entered the ports of Liverpool. ${ }^{13}$ In a two week period during April of 1848, thirty steamer vessels made 81 trips to Ireland bringing with them 15,334 people. During

\footnotetext{
${ }^{8}$ For further reading on this topic see: Donald Akenson, "An Agnostic View of the Historiography of the Irish Americans,” Labour/ Le Travail, 14 (Fall, 1984): 123-159; David Fitzpatrick, Irish Emigration, 18011921. Studies in Irish Economic and Social History, Volume I (Ireland: Society of Ireland, 1984); Sheridan Gilley, "The Roman Catholic Church and the Nineteenth-Century Irish Diaspora," Journal of Ecclesiastical History, 25 (April, 1984): 188-207; Andrew Greeley, The Most Distressful Nation (Chicago: Quadrangle Books, 1973); James Donnelly, The Irish Potato Famine (England: Sutton Press, 2001); Peter Gray, The Irish Famine (London: Thames and Hudson, 1995); Timothy Guinnane, The Vanishing Irish: Households, Migration and the Rural Economy in Ireland (Princeton: Princeton University Press, 1997); Janet Nolan, Ourselves Alone: Women's Emigration fro Ireland, 1885-1920 (Kentucky: University of Kentucky Press, 1989). While Nolan's work is beyond the time frame presented, it is nonetheless a critical text in discussing gender and immigration as it relates to Ireland.

${ }^{9}$ Thom's Irish Almanac and Official Directory, with the Post Office Dublin City and County Directory (Dublin: Alexander Thom and Sons, 1852), 90 and Thom's Statistics of Great Britain and Ireland (Dublin: Alexander Thom and Sons, 1868), 80.

${ }^{10}$ Thom's Statistics of Great Britain and Ireland, 1.

${ }^{11}$ Thom's Statistics of Great Britain and Ireland (Dublin: Alexander Thom and Sons, 1868), 87.

${ }^{12}$ Frank Neal, Black '47 and the Famine Irish (New York: St. Martin's Press, 1998), 7.

${ }^{13}$ M.M.G. Dowling, "Letter," Destitute Irish (Liverpool). Copies of, or extracts from, any correspondences address to the Secretary of State for the Home Department, relative to the recent immigration of destitute Irish into Liverpool (London: S.M. Phillips, 1847), 16.
} 
the entire twelve months of that year, 116,231 Irish paupers entered the city at the ports, bringing the total population of the region up to 2,067,301 according to the 1851

census. ${ }^{14}$ From 1846 to 1853 , one and a half million Irish landed in Liverpool. Of those numbers, one-third were recorded as paupers and the vast majority continued travelling on to other parts of the country. ${ }^{15}$ The census that year also reflected a 189 percent increase in the populations of the large towns in England as compared to 1801, an indication that the trends in Liverpool were not unique to that urban center alone. ${ }^{16}$

Mervyn A. Busteed and R.I. Hodgson surveyed the 1841 and 1851 records for Manchester's Irish Town and their research reflects a similar trend as that of Liverpool. By 1841, 12.5 percent of the city’s population was Irish. By 1851, that percentage had increased to 14.3 percent. They found that, in 1851, 44.1 percent of the city’s total population was Irish-born or had two parents who were Irish-born. They also concluded that 72.6 percent of the population lived on streets that were comprised of 50 percent or greater of Irish immigrants. ${ }^{17}$ The 1851 census reported that of the nine northern counties, 58 percent of the population reported Ireland as their place of birth. ${ }^{18}$ By the mid-1850s, the native Irish in Liverpool exceeded the populations in the majority of towns in Ireland itself. ${ }^{19}$

\footnotetext{
${ }^{14}$ Great Britain, Irish Steamers. Captain Denham's Report on Passenger Accommodations in Steamers between Ireland and Liverpool (London: Steam Navigation Department Board of Trade, 1849), 8 and Great Britain, 1852-53 Census of Great Britain, 1851. Population Tables. I. Numbers of the Inhabitants, in the years 1801, 1811, 1821, 1831, 1841, and 1851: Volume I (London: William Clowes and Sons, 1852), xviii. ${ }^{15}$ Frank Neal, “A Criminal Profile: The Liverpool Irish,” Transactions of the Historic Society of Lancashire and Chesire, Volume 140, (1991): 178.

${ }^{16}$ Great Britain, 1852-53 Census of Great Britain, xlviii.

${ }^{17}$ M.A. Busteed and R.I. Hodgson, "Irish Migrant responses to Urban Life in Early Nineteenth-Century Manchester,” The Geographical Journal, Vol. 162 No. 2 (July 1996): 141, 146.

${ }^{18}$ Neal, Black '47, 8.

${ }^{19}$ Ibid, 10.
} 
Like the great industrial centers to the north, London, a mere 122 square mile area, contained a total population of 1,745,601 in 1851 and a staggering 2,362,236 people by $1862 .{ }^{20}$ According to records, there were $10,917,433$ people in all of Great Britain in March of 1801. Fifty years later, that figure rose to 21,121,967. The 1851 census attributed this dramatic increase to the "Irish [who] have entered the British population in large numbers.” ${ }^{21}$ Just five short years later, the total population for the entire island was a staggering $22,080,444 .^{22}$

\section{Post-Famine Populations}

By the end of the 1860s, well over a decade after the famine crisis had passed, Ireland's population continued to fall as England's rose. The Great Famine had created a culture of emigration throughout Ireland and the population continued to look outward for any hope of improving their lot in life. ${ }^{23}$ In 1866, almost 47,000 people left Ireland while in 1867 , the total figure was just over $30,000 .^{24}$ From 1821 to 1871 the population of England and Wales increased nearly one hundred percent. The popular press largely contributed this increase to immigration and what they called the Irish Catholic "Divine Command to be fruitful and multiply,” thus adding their large families to the already

\footnotetext{
${ }^{20}$ Henry Mayhew and John Binny, The Criminal Prisons of London and Scenes of Prison Life (London: griffin, Bohn and Company, 1862), 11 and Great Britain, 1852-53 Census of Great Britain, xviii.

${ }^{21}$ Great Britain, 1852-53 Census of Great Britain, xxviii.

${ }^{22}$ Great Britain, Miscellaneous Statistics of the United Kingdom, 1857-58, 2427 (London: George Edward Eyre and William Spottiswoode, 1857), 1.

${ }^{23}$ For a further analysis of this culture of immigration see: Frank Neal, Black '47 and the Famine Irish (New York: St. Martin’s Press, 1998); Lyn Hollen Lees, Exiles of Erin, Irish Migrants in Mid-Victorian London (1979); L. Kennedy and L.A. Clarkson, "Birth, death and exile: Irish population history, 17001921” in An Historical Geography of Ireland, eds. B.J. Graham and L.J. Proudfoot (London: Academic Press, 1993); Cormac Ó Gráda, Ireland Before and After the Famine: Explorations in Economic History, 1800-1925, Second Edition (Manchester: Manchester University Press, 1993); Gerard Moran, Sending out Ireland's Poor: Assisted Emigration to North America in the Nineteenth Century (Four Courts Press, 2004).

${ }^{24}$ Thom's Statistics of Great Britain and Ireland, 79.
} 
overcrowded conditions of the cities. ${ }^{25}$ In 1841, there were only 284,128 persons who listed their country of birth as Ireland. By 1861, that figure rose to 580,487 persons, or 3.1 percent of the total population. ${ }^{26}$ Historians such as Roger Swift have argued that these figures are misleading as they do not reflect the actual number of Irish in England. As the census figures were decennial, they overlooked the intercensal periods of migration and the children of Irish immigrants, born in England, would not have been included either. ${ }^{27}$ These children, raised in Irish neighborhoods among an almost exclusively Irish population, would have been closer to their parents and the culture of Ireland than that of England. ${ }^{28}$

\section{Disease and Poverty in the Slums}

Although statistically the number of immigrants as compared to the total population of England was small, only 2.9 percent of the total population in 1851, the fear of these strangers congregating in specific cities grew disproportionately. ${ }^{29}$ In the 1830s, as poverty and disease increased in the urban centers, the middle class ratepayers could no longer ignore the problems as they had in the past. Parliament ordered numerous investigations into the conditions of the slums and the reports were often published as pamphlets or books and released to the general public. ${ }^{30}$ One of the earliest works, the

\footnotetext{
${ }^{25}$ Luke Owen Pike, History of Crime in England Illustrating the Changes of the Laws in the Progress of Civilisation: Written from the Public Records and Other Contemporary Evidence Volume II (London: Smith, Elder, and Co. 1876), 408 and The Pall Mall Gazette 5575, January 12, 1883.

${ }^{26}$ Thom's Statistics of Great Britain and Ireland (Dublin: Alexander Thom and Sons, 1868), 86.

${ }^{27}$ Roger Swift, Irish Migrants in Britain, 1815-1914: A documentary history (Cork: Cork University Press, 2002), 27.

${ }^{28}$ Edward Prince Hutchinson, Immigrants and Their Children (New York: Wiley, 1956$), 55$.

${ }^{29}$ Roger Swift, "Heroes or Villains? The Irish, Crime, and Disorder in Victorian England,” Albion: A Quarterly Journal Concerned with British Studies, Vol. 29 No. 3 (Autumn, 1997): 400; B. Collins, "The Irish in Britain 1780-1921,” in B.J. Graham and L.J. Proudfoot, An Historical Geography of Ireland, (London: Academic Press, 1993), 342.

${ }^{30}$ For more detailed analysis of the public health systems and the slum conditions see: A.S. Wohl, Endangered Lived: Public Health and Victorian Britain (London: Methuen, 1983); J. Burnett, A Social History of Housing (London: Methuen, 1980); Gareth Stedman Jones, Outcast London: Study in the
} 
1832 pamphlet from Dr. James Phillips Kay Shuttleworth was, as mentioned in prior chapters, very influential for its graphic portrayal of poverty. ${ }^{31}$ Shuttleworth made a direct connection in his pamphlet between the increase in poverty and wretchedness in the urban centers with the increasing Irish population in those same areas. ${ }^{32}$ While the Irish were not the only poor people living in such conditions, this work set a precedent for the image of the immigrant as a blight on society, lowering the standards of the hardworking Englishmen around them as its themes were repeated in other publications in later years. Dr. W.H. Duncan, head of the Liverpool Infirmery, echoed Shuttleworth's words almost a decade later in a report to Parliament on the conditions of the poor in the ghettos. He said the Irish were "rapidly lowering the standards of comfort among their English neighbours” by “communicating their own vicious and apathetic habits.” They were quickly "extinguishing all sense of moral dignity, independence, and self-respect." In a dark foreshadowing of the anger to come in later decades, he reported a "melancholy foreboding" that so long as the English working class were exposed to the "inroads of numerous hordes of uneducated Irish, spreading physical and moral contamination around them," then it will be in "vain to expect that any sanitary code" will have any impact on the slums of the city. ${ }^{33}$

In 1830, a new crusading Whig government was elected with a power base in the manufacturing industry and trade. This new administration had closer ties to the urban

Relationship Between Classes in Victorian Society (Oxford: Oxford University Press, 1971); F.B. Smith, The People's Health (London: Weidenfeld \& Nicolson, 1990).

${ }^{31}$ Dr. James Phillips Kay Shuttleworth, The Moral and Physical Condition of the Working Classes Employed in the Cotton Manufacture in Manchester, Second edition (London: Frank Cass and Co. Ltd., 1970). This work was originally published in 1832 in response to a cholera epidemic in the city.

${ }^{32}$ Ibid, 55.

${ }^{33}$ Dr. W.H. Duncan, Sanitary Inquiry:- England Local Reports on the Sanitary Condition of the Labouring Population of England, in Consequence of an Inquiry to be made by the Poor Law Commissioners (London: William Clowes and Sons, 1842), 294. 
centers and were, therefore, more aware of the deplorable conditions. ${ }^{34}$ The reports and investigations continued and the documentation emphasized that the conditions as they existed created an environment ripe for disease. The mortality rate was significantly higher in the areas populated by the immigrant communities as well. ${ }^{35}$ As early as 1836 , connections were being clearly drawn between the Irish immigrants and disease. Author John Revans argued that contagious fever "has for many years past been hardly known in England... except when it has been introduced by the poor Irish.”36 In his report to Parliament, Dr. Howard stressed the direct correlation between the density of the population and the mortality rate, particularly due to epidemics. ${ }^{37}$ In 1840 , London had 1172 cases of measles and the northwestern region, including Liverpool and Manchester had over 2200 cases. $^{38}$ The northwestern region also had over 2800 cases of smallpox and over 4500 cases of typhus that year. Dr. Howard also reported that in these urban regions, the recovery houses were "frequently overcrowded... from the constant immigration of Irish labourers, many of whom arrive here already affected.”39

As the Irish population in England continued to rise, fear of this blight, fear of the other, became more concrete. Early reports on the wretched levels of disease among the Irish escalated as the volume of immigrants increased in the industrial towns. Each year,

\footnotetext{
${ }^{34}$ J. Garrard, Leadership and Power in Victorian Industrial Towns 1830-80 (Manchester: Manchester University Press, 1983), 85. See also: D. Frazer, Power and Authority in the Victorian City (Oxford: Blackwell, 1979).

${ }^{35}$ Great Britain, Fourth Annual Report of the Registrar-General of Births, Deaths, and Marriages In England (London: William Clowes and Sons, 1842), 10.

36 "Review of John Revans: Evils of the State of Ireland,” Blackwood's Edinburgh Magazine 40:252 (October, 1836): 501.

${ }^{37}$ Dr. Baron Howard, Sanitary Inquiry:- England Local Reports on the Sanitary Condition of the Labouring Population of England, in Consequence of an Inquiry to be made by the Poor Law Commissioners, (London: William Clowes and Sons, 1842), 301.

${ }^{38}$ Great Britain, Fourth Annual Report of the Registrar-General of Births, Deaths, and Marriages In England, 206.

${ }^{39}$ Dr. Baron Howard, Sanitary Inquiry:- England Local Reports on the Sanitary Condition of the Labouring Population of England, in Consequence of an Inquiry to be made by the Poor Law Commissioners, 296.
} 
Parliament reviewed the effectiveness of the poor laws, and each year inspectors ranked the Irish neighborhoods as almost unlivable. By 1842, several years before the spike in famine immigration, the city of Liverpool already had one of the largest Irish communities in England. That year Parliament requested reports on the sanitary conditions of the laboring classes of England. Inspectors in Liverpool found 9500 cellars with no ventilation whatsoever with a total residence of almost 40,000 people. Just over 9000 resided in backhouses with most of the sides sealed off. ${ }^{40}$ These cellars, many below street level, were often damp with no ventilation and the "fluid matter of courtyard privies sometimes oozes through" and the filthy water collected on the dirt floors. ${ }^{41}$ By 1844, the year just before the first blight, the head of the Liverpool Infirmary, Dr. W.H. Duncan, declared Liverpool the "most unhealthy town in England" because of the disgusting conditions of its slums. ${ }^{42}$ By 1844 , twenty percent of the population across the city lived in cellars. ${ }^{43}$

Like Liverpool, Manchester was also home to large numbers of Irish and they too lived in dreadful conditions unfit for habitation. Dr. Baron Howard, sanitation inspector for the city, reported that "no description can convey anything like an accurate idea of the abominable state of these dens of filth, and wretchedness." Citing Little Ireland, the immigrant neighborhood, as the worst example in the city, he indicated that at least 200 houses had toilets that were in a "disgraceful state.” Huge numbers of the population lived in cellars with no beds and no ventilation. Drains were often "stopped up... with

\footnotetext{
${ }^{40}$ Great Britain, “Conditions in Liverpool,” Report to Her Majesty's Principal Secretary of State for the Home Department from the Poor Law Commissioners of the Labouring Population of Great Britain with Appendices (London: William Clowes and Sons, 1842), 441, 31.

${ }^{41}$ Ibid, 31.

${ }^{42}$ Dr. W.H. Duncan, First Report of the Commissioners For Inquiring into the State of Large Towns and Populous Districts (London: William Clowes and Sons, 1844), 13.

${ }^{43}$ Ibid, 22.
} 
clay" to prevent the water from flowing inside. ${ }^{44}$ His report to Parliament indicated that there were frequently six or eight beds in a single room "filled promiscuously with men, women, and children.” The floors were covered with the "filthy and ragged clothes" they had just discarded. ${ }^{45}$ The Irish frequently erected pigsties both in and around their dwellings, there were "open cesspools” in the streets, “excrementitious matter” about and the entire area was “offensive beyond description” with an utterly "reeking atmosphere."46

\section{The Financial Impact of the Irish Immigrants}

As the government sought solutions to the horrendous conditions of the urban ghettos, the price tag began to rise and the ever-present threat of increased taxes haunted the middle class. In 1842, a proposal for razing tenements and replacing them with newer cottages across Liverpool was put before the Secretary of State for Home Affairs. The proposal under consideration defined three different classes of housing. The lowest class, small with extremely limited space, would cost $£ 40$ per building with an estimated $£ 37,119$ needed for completion. The second class structure was slightly larger with a cost of $£ 65$ per building and an estimated $£ 46,050$ needed for construction. The final class of cottages, at $£ 92$ per building, would require $£ 26,322$ to complete. These cottages would then be sold or leased to the poor at extremely reasonable rates. Critical to the project, however, was the need for public taxes to subsidize not only the construction costs, but also the price differential between actual rent or purchase value and that which was going

\footnotetext{
${ }^{44}$ Great Britain, “Conditions In Manchester,” Report to Her Majesty’s Principal Secretary of State for the Home Department from the Poor Law Commissioners of the Labouring Population of Great Britain with Appendices (London: William Clowes and Sons, 1842), 39.

45 Ibid, 358-359.

${ }^{46}$ Ibid, 38-39.
} 
to be offered to the poor. ${ }^{47}$ Doctors offered another solution to halt the spread of disease by thoroughly cleaning the streets. The city inspectors of Manchester reported an estimated 40-60 thousand loads of refuse needed removed from the ghettos. Street cleaning needed to occur on a daily basis because of the unsanitary habits of the local populous with a total yearly cost of between $£ 20,000$ and $£ 30,000$. This expense would fall on the local taxpayers of the city. ${ }^{48}$

Not only were those unwilling or unable to work creating serious problems, but those who would work became a serious problem in the labor forces, particularly in the industrial north. The Irish were willing to work for lower wages, and thus provided competition for the English working-classes in the industrial centers. Like earlier generations, most of these new immigrants settled into low-skilled or semi-skilled employment. ${ }^{49}$ The average income in Ireland, according to English economist Robert Griffen, was less than one-seventeenth that of the average income of England. ${ }^{50}$ The low wages in the English cities were considered an improvement by the standards in Ireland, and these jobs provided an attractive alternative to starvation at home. By 1839, the number of workers registered in the larger towns and manufacturing districts had increased by as much as 120 percent from the figures in 1800. Manchester saw a 109

\footnotetext{
${ }^{47}$ Great Britain, Report to Her Majesty's Principal Secretary of State for the Home Department from the Poor Law Commissioners of the Labouring Population of Great Britain with Appendices (London: William Clowes and Sons, 1842), 400. This project was never fully implemented due to lack of funding. There were several very small scale attempts at improvement, but nothing to the original scope of the initial plans. ${ }^{48}$ Great Britain, "Conditions in Manchester," 53. Reports from all major cities reflected the same trends among the poor. They continually tossed refuse in the streets, refused to use bins, and allowed common toilet areas to become unusable. See Mr. Howell's report from London in Report to Her Majesty's Principal Secretary of State for the Home Department from the Poor Law Commissioners of the Labouring Population of Great Britain with Appendices, 46.

${ }^{49}$ Robert Miles, Racism and Migrant Labour (London: Routledge, 1982), 129.

${ }^{50}$ Robert Griffen, “The Economic Value of Ireland,” The Nineteenth Century: A Monthly Review, No. 109 (March, 1886): 334.
} 
percent increase, Liverpool increased by 100 percent and the proportion of laborers to farm workers in the Lancashire area was a disproportionate ten to one. ${ }^{51}$

Like the issue of uncleanliness, the battle over employment was not new either. In 1836, author John Revans argued that the "whole pressure of the population in the British islands on the means of subsistence comes from Ireland.” He argued that if England could "weed out of the great towns... all of the adult Irish who have settled there, even within the last twenty years, there would be full employment for all the natives.”52 Fraser's Magazine for Town and Country assailed the Irish a year later, charging that they were the "chief source of mendacity in London, Manchester, Leeds, and other large towns.” These immigrants, according to the magazine, “depress the English labourer, in competing with him for employment" and they exposed that same worker to their "halfcivilized habits” thus debasing his "manners and character.” The popular press repeated this same mantra again in 1850. Author Henry Grant, in his work Ireland's Hour argued that "hordes upon hordes of famishing Irish are flocking over to England,” and they were only succeeding "to lower a labour-market already too deeply depressed." 53 The themes of employment competition and the negative impact from Irish immigration was passed down from decade to decade as the actual number of Irish continued to increase across the country.

As the influx continued in the industrial regions, competition increased and the fear of job displacement became acute. Irish labor in the cotton industry of Manchester,

\footnotetext{
${ }^{51}$ Robert A. Slaney, Esq., State of the Poorer Classes in Great Towns. Substance of a speech in The House of Commons, February 4, 1840, on Moving for A Committee to Consider the Cause of Discontent (London: Longman and Co., 1840), 11-12.

52 "Review of John Revans: Evils in the State of Ireland,” Blackwood's Edinburgh Magazine 40:252 (October, 1836): 498.

${ }^{53}$ Henry Grant, Ireland's Hour (London: Thomas Hatchard, 1850), 3.
} 
for example, created a tighter labor market in the textile mills during the $1850 \mathrm{~s} .{ }^{54}$ The effects of immigration also created a tighter labor market in the railroad industry and weaving throughout England. ${ }^{55}$ Charles Wentworth Dilke argued that the Irish "pour in unceasingly" and will eventually "throng the cities," destroying the social and political structures for the "law-abiding Saxon." ${ }^{56}$ The Preston Guardian argued the Irish paupers arrived "half naked and half famished... in vast numbers" and had begun "spreading themselves throughout both the manufacturing and agricultural districts," thus “competing with our own population for employment.” Because the conditions of the Irishman was little better than a "Russian serf," he accepted "less wages for his labour" and thereby depressed the economic state of all workers. ${ }^{~} 57$ The Morning Chronicle in London stressed that day-laborers in the western regions were "more exposed to suffer than those of the east, from the competition of Irish immigrants." 58

Those Irish willing and able to work, and thus deserving of assistance, were enough of a threat to the livelihoods of the hard working English, but those unwilling or unable to work continued to add to the tax burdens. As the waves of paupers fled Ireland for greener pastures, the pauper rolls in England began to rise. In 1847, just a few short years after the first famine, Canon Abraham Hulme, an Anglican priest in Liverpool, took a survey of the Irish in his city. He questioned those Irish he considered settled, or permanent, residents. Of all the settled Irish in Liverpool, only 23 percent had regular

\footnotetext{
${ }^{54}$ N. Kirk, “Ethnicity, Class, and Popular Toryism, 1850-1870”, in Hosts, Immigrants and Minorities, ed. K. Dunn (New York: Folkstone, Dawson, Langholm, 1971), 85.

${ }^{55}$ J.H. Treble, “The Navvies,” Scottish Labour History Society Journal 5 (1973): 34-54.

${ }^{56}$ Charles Wentworth Dilke, Greater Britain: A Record of Travel in English-Speaking Countries, 1866 and 1867 (London: Macmillan and Co., 1868), 44.

57 "Condition of Ireland,” The Preston Guardian, 1791, December 24, 1846.

58 "Labour and the Poor: The Rural Districts,” The Morning Chronicle, 5039, January 19, 1850.
} 
work and 43 percent were paupers without any means of support. ${ }^{59}$ As a result, the tax burden on the English population rose accordingly. In 1837, the total expenditure for the poor under the Poor Laws of England amounted to £4,044,741. By 1845, the first year of the famine, that figure rose to $£ 5,039,703$. These expenditures were for the poor in England and Wales only and this money did not include the growing cost of the Poor Laws in Ireland itself. During this same period, the number of paupers registered in England and Wales rose by over 250,000 people, or one-tenth of the total population. ${ }^{60}$ In 1849, six percent of the population of England was registered on the pauper rolls and in 1851, that figure only fell by one percent. ${ }^{61}$ Liverpool reported a flood of relief requests from Irish paupers in 1846, issuing an average of 3,000 soup tickets and 2,000 rations of bread daily that year. Sir George Grey, the Liverpool Select Vestry to the Home Secretary, described the influx as “alarming.” According to Grey, Liverpool relieved 888 persons the week of December $10^{\text {th }}, 1845$ and during that same period in 1846, the number had escalated to 13,471 persons. ${ }^{62}$ Alfred Austin, an assistant Poor Law commissioner in Liverpool, reported even larger figures for January of 1847 . On the $4^{\text {th }}$ of that month, 3,189 requests were submitted and by the $18^{\text {th }}$ of that same month, the requests skyrocketed to 18,053 . By the $28^{\text {th }}$ of January the total number of requests had escalated to $24,297 .{ }^{63}$ In March of that year, the numbers spiked to $50,102 .{ }^{64}$ Visiting a

\footnotetext{
${ }^{59}$ Canon Abraham cited in Frank Neal, “A Criminal Profile: The Liverpool Irish,” Transactions of the Historic Society of Lancashire and Chesire, Volume 140 (1991): 197.

${ }^{60}$ Great Britain, The Poor Law Commission (London: G. Luxford, 1846), 9-11.

${ }^{61}$ Luke Owen Pike, History of Crime in England Illustrating the Changes of the Laws in the Progress of Civilization: Written from the Public Records and Other Contemporary Evidence: Volume II (London: Smith, Elder and Co., 1876), 421.

62 "Condition of Ireland," The Preston Guardian, 1791, December 24, 1846.

${ }^{63}$ Alfred Austin, "Letter," Destitute Irish (Liverpool). Copies of, or extracts from, any correspondences address to the Secretary of State for the Home Department, relative to the recent immigration of destitute Irish into Liverpool (London: S.M. Phillips, 1847), 5,9.
} 
friend in Liverpool, businessman Mr. W. Brown remarked that the "peasantry are coming over here in regiments" creating a "mass of human misery" across the city. ${ }^{65}$ London recorded a similar trend in its relief statistics. In 1839, the total requests for relief was a mere 356 people. That figure escalated to 33,655 in 1846 and jumped again to 41,743 requests in $1847 .{ }^{66}$ By 1855 , after a decade of famine in Ireland, the total number of paupers registered in England was 897,686 and a year later, that figure jumped to $917,084 .^{67}$

\section{Spreading Across England}

This “enormous pecuniary burden” added to the already negative image of the immigrant Irish. Demands for the "mitigation of the evil" resounded in the popular press. These immigrants were not moving on, but instead were becoming residents in the ports in which they arrived. Poor Law commissioner Mr. Loch Wosley reported that of all the immigrants who arrived in Liverpool in December of 1846, at least 15,000 of them stayed “at the expense of the community” as paupers. An “ocean of starving immigrants” was becoming a threat to English society. ${ }^{68}$ Town meetings were held to discuss some solution for "relieving the rate-payers from the enormous burdens imposed... [from] the great influx of Irish paupers.”69 In 1846, Sir George Grey was so disturbed by the rising tide of immigration that he issued instructions to the Liverpool ports to turn back any and

\footnotetext{
64 "Irish Immigration into Liverpool and Emigration from the Port," The Hull Packet and East Riding Times, 3248, April 23, 1847.

${ }^{65}$ W. Brown, “Letter,” Correspondences From July, 1846, to January, 1847, Relating to the Measures Adopted for the Relief of the Distress in Ireland. Board of Works Series (London: William Clowes and Sons, 1847), 343.

${ }^{66}$ Great Britain, Reports and Communications on Vagrancy (London: William Clowes and Sons, 1848 ), 74. ${ }^{67}$ Great Britain, Miscellaneous Statistics of the United Kingdom, 1857-58 (London: George Edward Eyre and William Spottiswoode, 1857), 38.

${ }^{68}$ Loch Wosley, Correspondences From July, 1846, to January, 1847, Relating to the Measures Adopted for the Relief of the Distress in Ireland. Board of Works Series (London: William Clowes and Sons, 1847), 436.

69 “Influx of Irish Paupers into Liverpool,” The Examiner, 2050, May 1847: 315.
} 
all ships carrying Irish to stop the influx. ${ }^{70}$ Those ships arriving into Liverpool were packed with as many as 300 deck passengers at a time, so many that it was necessary to herd them together with their luggage and cattle in order to carry the load. In order to increase their passenger capacity, some captains even filled the stables when they were empty to increase their profits. ${ }^{71}$ Reverend Augustus Campbell argued that unless a solution was found, "the Irish poor will continue to be better fed In (sic) England than in Ireland” and will "continue therefore to flock here."72

Assistant Poor Law Commissioner Alfred Austin reported that in Liverpool, “every street swarms with Irish beggars,” scenes reminiscent of travel diaries about Ireland's impoverished. ${ }^{73}$ The stipendiary magistrate for Liverpool, Mr. Rushton, stressed the need for immigration reform or "gaol accommodations” would be required for approximately “10,000 persons” violating the Vagrant Act. ${ }^{74}$ The popular press argued that the people of Liverpool have "always been willing to provide for their own poor," and never begrudged the English Poor Laws. However, they could not "see the invasion of the town by thousands without feeling the injustice of the burden entailed upon them.” The Economist argued that "to put food into the mouth of a poor man who cannot purchase it is to take it out of the mouth of another man,” and the English felt the Irish were taking far too much. ${ }^{75}$ To the public, the "Irish poor should be maintained by Irish

\footnotetext{
70 “Condition of Ireland,” The Preston Guardian, 1791, December 24, 1846.

${ }^{71}$ Great Britain, Irish Steamers. Captain Denham's Report on Passenger Accommodations in Steamers between Ireland and Liverpool (London: Steam Navigation Department Board of Trade, 1849), 4-5.

${ }^{72}$ Rev. Augustus Campbell, “Letter,” Destitute Irish (Liverpool). Copies of, or extracts from, any correspondences address to the Secretary of State for the Home Department, relative to the recent immigration of destitute Irish into Liverpool (London: S.M. Phillips, 1847), 11.

${ }^{73}$ Austin, "Letter," Destitute Irish (Liverpool), 7.

74 “Influx of Irish Paupers into Liverpool,” The Examiner, 2050, May 1847: 315.

75 “Charity as a Remedy in case of famine,” The Economist, Issue 118, November 29, 1845: 1193.
} 
lands and Irish property,” not England. ${ }^{76}$ English taxpayers, burdened by the ever increasing need to support the waves of immigrants, began to see their charity wane in the face of the Irish "habits of mendacity." ${ }^{77}$ Racial theorist Robert Knox raged against the influx of immigrants and argued that the Celtic race "must be forced from the soil... England's safety requires it." ${ }^{\text {"7 }}$ The Irish had become "dependent on the hardworking people" of England and it needed to stop. ${ }^{79}$

\section{Attempts and Failures to Stem the Tide}

Efforts to stem the tide, however, were limited at best and failed to reduce the overall numbers of immigrants. Urban centers quickly established or increased their residency requirements for poor relief and by the early 1830s, the large industrial centers such as Manchester had increased that requirement from ten to fifteen years to combat the influx of Irish. ${ }^{80}$ With the stiffer requirements, this left only four options available to the incoming poor. They could turn to private charity, ask for help from family and friends, ask for parochial relief, or turn to begging. The final option was often the first taken as any funds garnered from begging could be hidden from the Poor Law guardians when an individual did become eligible for relief. The Vagrancy Act, which made begging a crime, was supposed to curb this problem, but two problems immediately emerged as the number of immigrants continued to rise. First was the simple problem of space. There was not enough room in the jails to hold the number of beggars that would need arrested. Second was the logistical problem of care for prisoners once they were locked up. As

\footnotetext{
76 “Influx of Irish Paupers into Liverpool,” 315.

77 "Irish Immigration into Liverpool and Emigration from the Port,” The Hull Packet and East Riding Times, 3248, April 23, 1847.

${ }^{78}$ Robert Knox, The Races of Men: A Philosophical Inquiry into the Influence of Race over the Destinies of Nations, Second Edition (London: Henry Renshaw, 1862), 379.

79 “Influx of Irish Paupers into Liverpool,” 315.

${ }^{80}$ Great Britain, Report on the State of the Irish Poor in Great Britain, House of Commons, 40, (1836): 519-520.
} 
these were people without any means of support, jail provided a hot meal, a warm room, and a safe place to sleep for the night. This was a much more inviting option than the harsh urban streets. ${ }^{81}$

By the 1850s, requests for the removal of paupers, particularly the Irish, were coming from all over the country. As all funding for the Poor Laws came from local property taxes and not from a national tax base, the regions with the highest immigration were beginning to feel the financial strain. Chester, Glasgow, and Cardiff had all petitioned Parliament for assistance in getting rid of the influx of Irish paupers. Liverpool in particular set up a removal system in order to attempt to maintain some semblance of control over the crisis. The parochial authorities were "determined to free themselves from a burden which doesn’t belong to them,” a burden estimated at £30,000 with “neither end nor limit” as the Irish continued to come. ${ }^{82}$ Reverend Augustus Campbell testified before the Select Committee on Poor Removal in 1854 and he argued that the “enormous expenditure which was of a temporary character, has been succeeded by a permanent burden” on the people of the city. ${ }^{83}$ From the first of February to the thirtieth of April, 1848, 2,224 paupers were returned to Ireland for a variety of different reasons, but this paled in comparison to the numbers that continued to enter the ports. ${ }^{84}$ In June of 1846, pauper removal cost the city £106. By March of 1847, that figure rose to $£ 242$. Four months later, the expenditures rose to $£ 526$ and by December that figure had risen to

\footnotetext{
${ }^{81}$ Neal, Black '47, 145.

82 "Removal of Irish Paupers,” The Manchester Times and Gazette, 977, July 9, 1847 reprinted from The Liverpool Times, July 8, 1847.

${ }^{83}$ Rev. Augustus Campbell, "Report of the Select Committee on Poor Removal," Parliamentary Papers: Minutes of Evidence, 365-365.

${ }^{84}$ Great Britain, Irish Steamers. Captain Denham's Report on Passenger Accommodations in Steamers between Ireland and Liverpool (London: Steam Navigation Department Board of Trade, 1849), 14.
} 
£862. ${ }^{85}$ The city even considered extreme measures, such as those authorized by the lawsuit R. vs. Benett and Broughton in 1841. This case was a legal challenge against the removal of paupers and the state won. Cities could continue to separate families, including mothers and children, as long as the child was above the age of nurture. This meant that children as young as four and five years old could be removed to Ireland if the authorities saw fit. ${ }^{86}$ The Liverpool Mercury argued that the financial burden of the Irish, who simply continued to come unabated, needed to be shouldered not by the cities directly affected, but by all of England as this was becoming a national crisis. ${ }^{87}$

\section{Slum Conditions Continue}

These new immigrants into England, like those of prior decades, settled in the worst neighborhoods and continued to live in as wretched conditions as their countrymen before them. The Northern Star and National Trades' Journal ran a feature on the crisis in Manchester in 1847. The newspaper reported appalling stories of overcrowding in the Irish areas, such as Cayley-street. A "wretched class of people” was packed into the lodging-houses there. In one instance, there were five families with twenty-two people stuffed into two tiny rooms and the health inspectors, according to the article, found a dead person in the corner of one of the rooms amidst the families. ${ }^{88}$ The Irish in Liverpool were no different, living in dwellings "previously condemned and closed as

\footnotetext{
${ }^{85}$ Liverpool Mercury, January 7, 1848.

${ }^{86}$ Great Britain, Seventh Annual Report of the Poor Law Commissioners with Appendices (London: William Clowes and Sons, 1841), 32-33.

87 "Frightful Distress in Liverpool," Liverpool Mercury, January 15, 1847.

88 "The Famine and Destitution in Manchester," The Northern Star and National Trades’ Journal 506, July 3, 1847.
} 
unfit for human habitation.” ${ }^{89}$ These immigrants were, quite simply, "lazy besotted worthless tenants, wallowing in sloth and filth... from whom no good will come.”90

Prior to the famine, the public saw the pauper rolls escalate in the wake of epidemics because once the head of the household fell ill, he and his family turned to the Poor Laws for relief. ${ }^{91}$ This pattern continued on a much larger scale as the waves of famine immigrants hit English shores. In 1841, 32.1 percent of all deaths in England were contributed to zymotic or epidemic diseases and by 1851, after years of famine immigration, that figure rose to 40.7 percent of all deaths. ${ }^{92}$ Nationwide expenses on medical care for the poor rose in proportion to the immigration figures. Public expenditures on care, excluding all private and charitable facilities, were just over $£ 136,000$ in 1838 . The year just prior to the famine, those expenses had risen to $£ 166,257 .^{93}$

These new immigrants were becoming a serious threat to the industrial centers, but they were also an indirect threat to the middle classes as well. The other had invaded not only the working class neighborhoods with his filth, but he brought the very real threat of disease to the larger English population. According to health inspectors, the immigrants were the largest single focal point for epidemics, just as they had been years earlier. Newspapers reported that in spite of every attempt to clean the cities, mortality continued to increase because of the "influx of poor Irish... many of whom arrive in a

\footnotetext{
89 “Influx of Irish Paupers into Liverpool,” 315.

90 The Nation, September 15, 1849: 40.

${ }^{91}$ Dr. Baron Howard, Sanitary Inquiry:- England Local Reports on the Sanitary Condition of the Labouring Population of England, in Consequence of an Inquiry to be made by the Poor Law Commissioners (London: William Clowes and Sons, 1842), 303.

${ }^{92}$ Thom's Statistics of Great Britain and Ireland (Dublin: Alexander Thom and Sons, 1868), 83.

${ }^{93}$ Great Britain, Eleventh Annual Report of the Poor Law Commissioners with Appendices (London: William Clowes and Sons, 1845), 15.
} 
complete state of destitution." ${ }^{94}$ Out of every one thousand children in the city of Manchester, 570 died before their fifth birthday of a wide variety of diseases, including the dreaded fever associated with the Irish paupers. ${ }^{95}$ During an epidemic in 1838 in Liverpool, 32.73 percent of the fever cases reported to the North Dispensary were from the Irish while only 26.07 percent were among the English population. Across the city, the Irish accounted for 43.5 percent of all fever cases yet they represented a relatively small portion of the overall population. ${ }^{96}$ Whitechapel and Bethnal Green, both very poor districts in London heavily populated by the Irish, registered 4,640 fever cases in $1839 .{ }^{97}$ In 1840, Liverpool registered 5,597 deaths from this fever and the average age of death for males was fifteen years old. ${ }^{98}$ During this bout with fever, the area most heavily populated with Irish, Lace-street in Irishtown, and the most densely populated with only four square yards per person, was the source of one in eight of the cases reported to the health authorities with a fever rate of 87.22 percent of the total population of that area. ${ }^{99}$ That same year, one of the poorest neighborhoods in London with the largest population of Irish, reported 1,762 fever deaths with an average mortality age of twenty-two. ${ }^{100}$

\footnotetext{
94 "Health of Towns," The Bristol Mercury, 2980, May 1, 1847.

${ }^{95}$ Great Britain, Report to Her Majesty's Principal Secretary of State for the Home Department from the Poor Law Commissioners of the Labouring Population of Great Britain with Appendices (London: William Clowes and Sons, 1842), 179.

${ }^{96}$ Dr. W.H. Duncan, First Report of the Commissioners For Inquiring into the State of Large Towns and Populous Districts (London: William Clowes and Sons, 1844), 30.

${ }^{97}$ Robert A. Slaney, Esq., State of the Poorer Classes in Great Towns. Substance of a Speech in the House of Commons, February 4, 1840, on Moving for a Committee to Consider the Cause of Discontent (London: Longman and Co., 1840), 30.

${ }^{98}$ Great Britain, “Conditions in Liverpool,” Report to Her Majesty's Principal Secretary of State for the Home Department from the Poor Law Commissioners of the Labouring Population of Great Britain with Appendices (London: William Clowes and Sons, 1842), 159.

${ }_{99}$ Dr. W.H. Duncan, Sanitary Inquiry:- England Local Reports on the Sanitary Condition of the Labouring Population of England, in Consequence of an Inquiry to be made by the Poor Law Commissioners (London: William Clowes and Sons, 1842), 290 and Dr. W.H. Duncan, First Report of the Commissioners, 29.

${ }^{100}$ Great Britain, “Conditions in the Metropolis,” Report to Her Majesty's Principal Secretary of State for the Home Department from the Poor Law Commissioners of the Labouring Population of Great Britain with Appendices (London: William Clowes and Sons, 1842), 160.
} 
Manchester reported that one in four of the poor died of fever that year. ${ }^{101}$ These figures, all gathered before the waves of famine immigration, indicated an already growing problem in the urban slums; one that was only destined to get worse as the desperate sought relief in the urban centers of England in the mid-1840s.

In 1847, there was an outbreak of typhus in Liverpool that quickly escalated in an epidemic. Medicine during this period was still far from understanding the origins of diseases, and physiology prevailed over aetiology. Doctors produced lists of predisposing factors, such as dampness, poor air supply and poor sanitation, that caused typhus, thus directly linking the outbreak of the disease to the lower class neighborhoods, particularly the Irish towns. ${ }^{102}$ The initial outbreak was among the poor populations of the city and it was present on the steamers dropping Irish paupers into Liverpool at record rates. The Liverpool Mercury did a feature article on the health of its hometown, one of England's most populous cities. According to the newspaper, "in the streets occupied more particularly by Irish... mortality [from fever] have been trebled.” Just as they did in the 1830s, Irish immigrants continued to arrive "in a state of disease," causing the fever to make “rapid progress.” Just as the prior decade, the cause of the problem was “attributed to the large influx of Irish poor, who crowd together in the most unhealthy districts.” In January and February of that year there were 1230 cases of fever reported in the two areas dominated by the Irish that, according to the article, corresponded with a significantly large spike in the number of Irish immigrants into the Liverpool ports during

\footnotetext{
${ }^{101}$ Great Britain, “Conditions in Manchester," Report to Her Majesty's Principal Secretary of State for the Home Department from the Poor Law Commissioners of the Labouring Population of Great Britain with Appendices (London: William Clowes and Sons, 1842), 163.

${ }^{102}$ Neal, Black' '47, 124.
} 
the same period. ${ }^{103}$ Dr. W. H. Duncan, a health inspector for Liverpool, found larger numbers of fever cases among the "Irish in a state of destitution.” During his rounds in the month of January, 1847, he reported twenty-two cases in the Great George and Pittstreet area. Of those, fourteen were Irish from the overcrowded lodging-houses. Of the 90 patients in the fever house that month, 73 were Irish. Thirty of those 73 had been in the country less than three months and were thus carrying diseases into England. Of the five deaths on Lace-street in the first week in February of that year, three were Irish. ${ }^{104}$ The local Registrar reported that there were 1134 more deaths in 1847 than the previous year and he contributed this solely to the "many thousands of Irish paupers” who brought a “malignant fever, which is here very properly called the 'Irish Fever.",105 There were even reports of dead bodies being carried off the steamer ships from Ireland as well as large numbers of sick people on board, another clear indication the paupers were bringing the illnesses with them. ${ }^{106}$ Dr. Duncan warned that the "destitute Irish still flock into the town,” and he stressed that there "can be little doubt that” Liverpool was on the verge of the “most severe and desolating epidemic" of the city’s last ten years. ${ }^{107}$

The problem became so severe that emergency measures were implemented to deal with the growing number of sick and dying. In May of that year, the city allocated $£ 2100$ to build three sheds to house patients. The chapels and meeting halls of the

\footnotetext{
103 “The Health of the Town,” The Liverpool Mercury, 1869, February 26, 1847.

${ }^{104}$ Dr. W. H. Duncan, "Letter,” Destitute Irish (Liverpool). Copies of, or extracts from, any correspondences address to the Secretary of State for the Home Department, relative to the recent immigration of destitute Irish into Liverpool (London: S.M. Phillips, 1847), 139.

105 “Bills of Mortality,” Chamber's Edinburgh Journal 180, (June 12, 1847): 373 and “Immigration of Irish Poor into Liverpool,” The Morning Chronicle, 24671, November 16, 1848.

${ }^{106}$ Great Britain, Irish Steamers. Captain Denham's Report on Passenger Accommodations in Steamers between Ireland and Liverpool (London: Steam Navigation Department Board of Trade, 1849), 17.

${ }^{107}$ Dr. W. H. Duncan, “Letter,” 14.
} 
workhouses were commandeered as temporary hospitals as well. ${ }^{108}$ In May alone, there were 551 reported deaths from the fever, but the true figure was likely far greater as many deaths in the poorest neighborhoods often went unrecorded. ${ }^{109}$ Fear of the summer heat and the continued influx of paupers heightened the tension in the city and in June, the Liverpool Albion suggested using Hilbre Island as a quarantine center. The newspaper claimed that there were over 8000 people being treated for the fever and the Irish needed to be isolated to stop the epidemic. ${ }^{110}$ While the island was never occupied by fever victims, several ships were used as quarantine centers to isolate the sick. The Newcastle and The Akbar were both converted to temporary hospitals and the infected Irish were removed from the steamers as they docked and taken directly to the ship hospitals to keep them from entering the general population of the city. ${ }^{111}$ The Liverpool Journal reported that many of the immigrants entering the port had only been in the city for a few days before they died, thus adding funeral costs onto medical costs for the English taxpayer. ${ }^{112}$ The problem became so intense in the Irish neighborhoods that a newspaper headline read "A Skibbereen in Liverpool” in reference to the massive wave of death that swept through the tiny town in Ireland in the early years of the famine. ${ }^{113}$ The media demanded the Irish be sent back without ever being allowed to disembark as the English had "no right to sit still and let pestilence walk among us.”114

\footnotetext{
${ }^{108}$ Liverpool Courier, May 24, 1847.

${ }^{109}$ Neal, Black'47, 128.

${ }^{110}$ Liverpool Albion, June 26, 1847.

${ }^{111}$ Liverpool Standard, June 16, 1847.

${ }^{112}$ Liverpool Journal, February 6, 1847.

${ }^{113}$ Liverpool Journal, March 13, 1847.

${ }^{114}$ Liverpool Mercury, February 12, 1847.
} 


\section{Diseases Spread Across England with the Irish Immigrants}

Had the fever remained a Liverpool problem, it would have likely vanished into the city’s history as simply one more outbreak, but this time the disease moved beyond the city limits to the rest of England. As Liverpool was the largest entry point, the numbers of Irish swelled throughout the city. Health issues and housing became a twofold problem in the poor neighborhoods. In 1842, the city had passed numerous laws to improve the health standards of the ghettos. One of these laws involved clearing the cellars and by 1846, 3000 had been vacated. By 1847, however, this program lapsed as the city struggled to house the endless stream of immigrants from Ireland. ${ }^{115}$ Many began moving elsewhere to find employment and housing as both became scarce, particularly in light of the economic problems in Europe at the time. The Manchester Guardian reported that the Irish had established travel routes that began in Liverpool and spread like a web across England. The newspaper also indicated that the fever travelled these same routes. A popular route south was from Liverpool through Warrington to Sandbach, and the cases of fever in those areas increased as the Irish moved. The vagrants were now spreading disease “among the respectable families” of England as well as among their own. ${ }^{116}$ Manchester itself reported that the city was unable to slow the spread of fever “which prevails amongst the wretched Irish immigrants in the cellars and lowest lodginghouses.” In order to present readers with an accurate depiction of the crisis, The Northern Star and National Trades' Journal reported on the findings of the medical inspectors as they travelled the streets of Manchester. According to the newspaper, on the first Saturday in July, five persons were found ill at number 48 Hanover-street without ever

\footnotetext{
115 Manchester Guardian, July 7, 1847.

${ }^{116}$ Manchester Guardian, May 22, 1847.
} 
seeking medical attention. Eight persons were found ill in a cellar at number five Simpson-street and twenty-two people were found ill at 13 Cayley-street. If these figures represented one day in Manchester, the newspaper asked its readers to consider the longterm scope of the Irish fever throughout the city. ${ }^{117}$ Chamber's Edinburgh Journal issued a distressing message to its readers in 1847 concerning the immigrants. The magazine warned the public that "so many thousands of Irish are continually pouring in, and their habits are so disgustingly filthy, that little can be done as yet to stay the great mortality amongst them.”118 The Manchester Guardian summed up Little Ireland as a "seat of squalor" and a "nucleus of fevers and other fouls diseases." ${ }^{119}$ By the early 1850s, the average yearly mortality within the Manchester city limits was over 7,000 people a year among a population of just over 228,000. This was due, according to sanitation inspector William Royston, to the "density of population" because the "lowest section of society... herds together... [and] are the most filthy in their habits.”"120

As the Irish moved inland, so too did disease, poverty and the life of the ghetto. The town of Halifax, a center of England's woolen manufacture in West Yorkshire, began experiencing the pressure of immigration in 1847. The Halifax Guardian reported that the "lowest of the Irish... infest every corner" of Swallow Street bringing with them a “pestilential epidemic.” ${ }^{121}$ As their numbers increased, so too did the cases of typhus as the overcrowded lodging houses were filled with "half starved and diseased beings" as

\footnotetext{
117 “The Famine and Destitution in Manchester,” The Northern Star and National Trades' Journal 506, July 3, 1847.

118 “Bills of Mortality,” Chamber's Edinburgh Journal 180 (June 12, 1847): 373.

${ }^{119}$ Manchester Guardian, May 12, 1847.

${ }^{120}$ Great Britain, Variation of the death rate in England: being the substance of a paper read before the Committee of the Manchester and Salford Sanitary Society (Manchester: Cave \& Sever, 1860), 10-12.

${ }^{121}$ Halifax Guardian, April 10, 1847.
} 
the Irish poured into town. ${ }^{122}$ Families such as the McAndrew family, were found living in ditches dying of the fever. The family was found living in a drainage ditch on a farmer's property in July of 1847. The father and four children died in a hospital of fever, but most significantly the Guardian reported, the fever had spread to the farmer's family who had shown them kindness and charity. Thomas Constable, owner of the Manor House property in Otley Yorkshire had also opened his land to the Irish. He too experienced an outbreak of typhus on his property and was forced to remove the Irish vagrants and forbid squatting on his land. ${ }^{123}$

Another major urban center in the Yorkshire area, Leeds, experienced the same pattern of disease and poverty among the growing Irish community. Like Halifax, Leeds had developed into a major wool industry but flax, engineering, iron foundries and printing were also important to the economic base of the city. The Leeds Mercury reported the same refrain as the other industrial cities concerning the "deplorable” condition of the Irish arriving the city and, like the other regions, the city also experienced a significant increase in the number of fever cases being reported. ${ }^{124}$ Gouldens Buildings, Gouldens Square and Back York Street were havens of "wretchedness, filth and disease” as the Irish settled in the worst neighborhoods in town. ${ }^{125}$ The city attempted to make repairs and improvements to the worst of the slum houses throughout the late spring of 1847, but according to the press, "owing to their filthy habits and the large numbers of individuals who are crowded together” the money

\footnotetext{
${ }^{122}$ Halifax Guardian, April 24, 1847.

${ }^{123}$ Halifax Guardian, July 10, 1847.

${ }^{124}$ Leeds Mercury, May 1, 1847.

${ }^{125}$ Leeds Mercury, April 24, 1847.
} 
was wasted as it took very little time until the homes were "rendered wholly unfit to live in and become the nurseries of diseases” all over again. ${ }^{126}$

Other areas also reported the same story of disease, death and poverty. The Newcastle Journal stated the region was "overrun with Irishmen who are in a most miserable condition” and indicated that expenditures on the Poor Laws for the area had nearly doubled the usual rate due to this influx. ${ }^{127}$ As the largest of all the urban centers, London had reported a similar pattern of disease, epidemics, and deaths in the years prior to the famine. The death rate from smallpox in the slums, for example, rose from 1,235 in 1840 to 1,804 in 1844 , the year just before the first blight. ${ }^{128}$

These reports all depict horrific scenes of disease and death that had a powerful impact on the middle class of England. The conditions of poverty clashed with Victorian notions of hygiene, cleanliness, and propriety that were becoming more popular as the century progressed. Some of these reports, however, were not intended to create a negative image of the immigrants, but were designed to raise sympathy and awareness for their plight. The Northern Star and National Trades' Journal, for example, was run and edited by Feargus O’Connor, one of the prominent leaders of the Chartist Movement. The paper's aim mirrored that of the national Chartist goals toward the end of the 1840s. As the movement sought greater unity with the Irish nationalists, it was only logical to show that support by drawing attention to the plight of the Irish poor in the massive industrial centers, particularly in the north. These same reports, however, were also being published in more mainstream, popular publications, such as local newspapers, and the tone of

\footnotetext{
${ }^{126}$ Leeds Mercury, June 19, 1847.

${ }^{127}$ NewCastle Guardian, March 27, 1847.; NewCastle Guardian, May 1, 1847.

${ }^{128}$ Great Britain, Eleventh Annual Report of the Poor Law Commissioners with Appendices (London: William Clowes and Sons, 1845), 17.
} 
many of these articles was not sympathetic to the Irish people. In addition, The Northern Star and National Trades' Journal, as the print voice of Chartism, was swept up in the rising anti-Chartist sentiment. The sympathy the journalists hoped to elicit was drowned out in the larger popular media of the period. To the middle class ratepayer absorbing information from the popular press, England was now facing the full impact of the other as a harbinger of disease and poverty. This epidemic on the eve of the new decade set the stage for the racial prejudice toward the Irish in the 1850s and later decades.

\section{The Origins of the Irish as Subhuman}

As the popular media began to fill their pages with horror stories of diseased, wretched creatures from across the Irish Sea, a distinct air of superiority crept into the English psyche. These beings filling the slums were morally bankrupt, devoid of human essence, and were a bane to the working people of England. As early as 1842, Dr. Howard referenced the “depraved and blunted state” of the Irish paupers’ emotions as he inspected their filthy hovels. ${ }^{129}$ That same year, Mr. Randall Wood, sanitation inspector for Liverpool and Manchester argued that those two great cities were the source of the greatest overcrowding because of their growing immigration problem. Like Dr. Howard, he felt these people were depraved and immoral. During his inspections, he found "three beds" in two apartments containing "two unmarried females” in bed together. The females' room had no divisions and across from them he found a man and wife. A mother of fifty was found in bed with her twenty-five year old son. A mother and her grown daughters were "sleeping on a bed of chaff on the ground in one corner... and in the other in a single room. This depravity, according to Wood, led to an almost complete breakdown of moral decency and the women, "having lost her character," became

${ }^{129}$ Great Britain, “Conditions in Manchester,” 359. 
prostitutes and all “sense of decency was obliterated” among this debased community. ${ }^{130}$ An 1848 health inspection in London found that due to the overcrowded conditions of the Irish slums, it was "physically impossible to preserve the ordinary decencies of life.” The inspectors found a "picture... of human wretchedness" amongst the poverty. Life there was filled with "filth, and brutal degradation... which are a disgrace to a civilized country.”131 This overcrowding, according to the report, was directly related to the huge influx of Irish from the famines of 1846 and 1847 with two-fifths of the Church Lane population being native Irish. ${ }^{132}$ Even their conduct on the steamer ships included “scenes of debauchery” as there were no separate spaces for women and children. ${ }^{133}$ It was not surprising, therefore, that they naturally continued this behavior in the slums of the urban areas. According to the popular press, the poor of England were being "brought down both physically and morally to the Irish level” as they simply did not care about anything related to civilization or humanity. ${ }^{134}$ Irish paupers came to be seen as carriers of a moral plague that might contaminate even the most stolid English workers, engendering a "spirit of discontent” and making either a decline or a general collapse of English industry inevitable. As a result, England might "sink from her high estate to the level of those whose sorrows she has so long deplored.” 135 This fear led the normally level-headed economist George Poulett Scrope to exclaim that the continuation of the

\footnotetext{
${ }^{130}$ Great Britain, “Mr. Randall Wood’s Report,” Report to Her Majesty's Principal Secretary of State for the Home Department from the Poor Law Commissioners of the Labouring Population of Great Britain with Appendices (London: William Clowes and Sons, 1842), 124-126.

${ }^{131}$ Great Britain, Report of a Committee of the Council of the Statistical Society of London, consisting of Lieut.-Colonel W.H. Sykes, V.P.R.S., Dr. Guy, and F.G.P. Neison, Esq., to their dwellings in Church Lane, St. Giles’s (January 17, 1848), 17.

132 Ibid, 20.

133 Great Britain, Irish Steamers. Captain Denham's Report on Passenger Accommodations in Steamers between Ireland and Liverpool (London: Steam Navigation Department Board of Trade, 1849), 5.

${ }^{134}$ Influx of Irish Paupers into Liverpool,” The Examiner 2050, May 15, 1847.

135 Mrs. K.C. Maberly, The Present State of Ireland, and Its Remedy (London: James Ridgway, 1847), 12.
} 
process would "spread through Britain the gangrene of Irish poverty, Irish disaffection, and the deadly paralysis of industry that necessarily attends upon these elements of evil.”136 Even for Scrope, the Irish peasants were no longer objects of sympathy, but carriers of a moral disease. They "wastefully consum[e] whatever they obtain, whether by alms, by plunder, or from public charity.” These paupers, he argued, spread “misery, disease, and disaffection over the land," and this was a threat to the "public tranquility, the security of property, the permanency of our social institutions, and,” he argued, the very "safety and integrity of our empire."137

The English worker became the model of the civilized working class and the Irish his complete opposite. The Irishman became an untrustworthy, immoral character living off the backs of hardworking Englishmen. Even Reverend Edward Dill, an early advocate for the impoverished of Ireland, began to change his perspectives in the wake of the ongoing crises in both Ireland and England. "How then,” he argued, "shall we compare the lower classes” of both Ireland and England. His description of the Irish peasant in his “wretched hut” and the "happy English... in his cheerful cottage” painted a clearly oppositional picture of the two cultures. ${ }^{138}$ Mr. Richard Griffith, a landowner in Galway, described how the Irish were prone to insubordination and "illtreated and struck the overseer” of the relief work. Once the agitation was quelled, police found $£ 25$ in "silver and notes” in the pocket of the ringleader, this in spite of his claims of poverty. ${ }^{139}$ These aggressive savages could not be trusted in their own home country, yet they came to

\footnotetext{
${ }^{136}$ George Poulett Scrope, How to Make Ireland Self-Supporting; or, Irish Clearances, and Improvements of Waste Lands (London: James Ridgway, 1848), 28.

137 Ibid, 30.

${ }^{138}$ Reverend Edward Marcus Dill, The Mystery Solved: or Ireland's Miseries; The Grand Cause, and Cure (Edinburgh: Johnstone and Hunter, 1852), 11.

${ }^{139}$ Mr. Richard Griffith, “Letter," Correspondences From July, 1846, to January, 1847, Relating to the Measures Adopted for the Relief of the Distress in Ireland. Board of Works Series (London: William Clowes and Sons, 1847), 170.
} 
English shores demanding help. The press had told similar stories in the early 1840s when the Irish would come to England for work, earn a considerable sum of money, and then “apply to be sent home” under the English Poor Laws removal system. There was a case in Stepney Union whereby, according to officials, an Irishman and his family had been living in England for several years and he had worked as a corn porter. He fell ill and applied for relief aid to return to Ireland. Three days prior to his application, he reportedly withdrew $£ 10.30$ from the Whitechapel Savings Bank, his accumulated earnings and enough to pay for his entire family’s fare. Other reports indicated that it was routine to find money hidden on Irish laborers when they applied for relief at the workhouses and many made a frequent habit of "remitting their earnings through the post office” in order to help their families in Ireland while still applying for aid in England. ${ }^{140}$ Reverend Theobald Mathew argued that when the Irish congregated together, "they always remain the same... of the same Habits and Dispositions as at Home” and he stressed, “Dissipation and Rioting are perpetuated among them.”141 Their habits in Ireland, deception, aggression, and shiftiness, were simply transplanted to English shores at the expense of the English taxpayer.

\section{Fear of the Catholic Other}

This hostility directed at the Irish was fuelled by the fear of change from the outsider. The Irish, although technically a part of the United Kingdom ever since the Act of Union, were foreign to the people of England. They were disease-ridden vagrants moving across the nation, taking jobs, and most importantly, threatening English values

\footnotetext{
${ }^{140}$ Great Britain, Seventh Annual Report of the Poor Law Commissioners with Appendices (London: William Clowes and Sons, 1841), 33.

${ }^{141}$ Rev. Theobald Mathews, “Letter,” Correspondences From July, 1846, to January, 1847, Relating to the Measures Adopted for the Relief of the Distress in Ireland. Board of Works Series (London: William Clowes and Sons, 1847), 253.
} 
and the English way of life. On the surface, this threat was obvious in the degradation of their living conditions, their deplorable habits, and their invasion of the working class employment. There was a much darker, more insidious threat that these foreigners brought to English shores however. These people were Catholic. Anti-Catholic sentiments ran deep in English history, dating back to the split between Henry VIII and the Pope over his divorce issues. Periodic slaughters occurred and by the 1700s, Catholics had been marginalized throughout England by sheer physical destruction in earlier centuries and legal isolation in later ones. With the Act of Union, however, an entire Catholic nation was absorbed into the United Kingdom under the guise of equal status for its people. Yet the Irish could never be equal to the English because of the laws against Catholics that now applied to both nations after 1801. In 1828, O’Connell and others fought and won emancipation for Catholics, thus giving them access to the political process, but these gains were not significant enough to bring complete equality. As unhappy as the English may have been about this, the numbers, or lack thereof, prevented any powerful Catholic voice in government. This ensured the Protestant English way of life would not be affected by this superstitious lot.

The famine changed all that. Suddenly English shores were awash with not only destitute savages, but Catholic ones at that. These were people loyal to the Pope, not the Crown. This same pope interfered in international affairs as if he was a statesman instead of a religious leader and the priests were seen as constantly meddling into the public and private affairs on a local level. The religion was filled with medieval superstitions and idolatry as it refused to evolve and accept the modern world as defined by the Protestant Reformation. 
Hostility toward the Catholic Church intensified during the famine as accusations were made against priests and the Church, particularly in relation to the escalating violence. By the 1850s, the Irish other had invaded not only the large industrial cities, but they had established a foothold in smaller towns in both the north and south of England and that meant Catholicism was also invading England. The foundation of faith in the United Kingdom, Protestantism, was under threat from these foreigners. The decade began with Catholic controversy when Pope Gregory IX issued the papal bull Universalis Ecclesiae on 29 September of 1850 which, according to historian J. F. Maclear, was spurred partly by the vast numbers of Irish immigrants into England in the late 1840 s. ${ }^{142}$ The order reestablished the Roman Catholic Hierarchy in England, which had effectively vanished with the death of the last Marian bishop in the reign of Elizabeth I as England became a solidly Protestant nation. From 1688 to 1850, for example, a bishop was called a Vicar Apostolic and was given certain districts to oversee. The Vicar Apostolic of the London District, for example, acted in the same capacity as the traditional Catholic bishop, but with the different title. After the Catholic Relief Act of 1829, subtle changes began on an informal level. The Irish immigrants, for example, continued to use the old Catholic titles, even though they were not in effect for the Catholic religious leaders in England. ${ }^{143}$ With the papal bull, the changes were made official. Westminster became the metropolitan see and its occupant the practical Catholic equivalent of the archbishop of Canterbury. This new structure replaced the four Vicars Apostolic who had been

\footnotetext{
${ }^{142}$ J. F. Maclear, Church and State in the modern Age: A Documentary History (Oxford: Oxford University Press, 1995), 148.

${ }^{143}$ Ibid, 148.
} 
ministering to English Catholics since the seventeenth century with the proper Catholic hierarchy as defined by Rome. ${ }^{144}$

English Cardinal Nicholas Wiseman fanned the flames of controversy shortly after the papal bull was issued with his pastoral letter entitled "From The Flaminian Gate at Rome.” After the bull took effect, he was named the first Archbishop of Westminster and vehemently denounced his Protestant enemies. Even Dr. Robert Whitty, the Cardinal's Vicar-General was reportedly aghast at its inflated rhetoric and hesitated to publish it, but eventually relented. ${ }^{145}$ Wiseman posited that England had now returned to the Empire of the Catholic Church and the only valid authority for Catholics in the United Kingdom was the Vatican. ${ }^{146}$ He stated that the "greatest of blessings" had bestowed upon England by the "restoration of its true Catholic hierarchal government.” ${ }^{147}$ Catholic England, according to Wiseman, "has been restored to its orbit in the ecclesiastical firmament” as the "great work is now complete.”148 To Protestant England, his words no doubt stirred images of rebellion and bloodshed from centuries past. England had long ago subdued the Catholic threat inside her borders, but now the Irish immigrants were bringing their turbulent religious problems and superstitious faith to peaceful English towns across the country.

\footnotetext{
${ }^{144}$ John Alzog, Manual of Universal Church History: Volume 3 (London: The Robert Clarke Co., 1903), 735.

${ }^{145}$ William Samuel Lilly, Studies in Religion and Literature (London: Chapman \& Hall, ld., 1904), 202.

${ }^{146}$ J. A. Wylie, Rome and Civil Liberty (London: Kessinger Publishing, LLC, 1865), 32. See also: Vincent Alan McClelland and Michael Hodgetts, From Without the Flaminian Gate: 150 Years of Roman Catholicism in England and Wales 1850-2000 (New York: Darton Longman \& Todd, 1999); Richard J. Schiefen, Nicholas Wiseman and the Transformation of English Catholicism (New York: Patmos Press, 1984)

147 “The Recent Papal Bull,” The Gentleman’s Magazine: Volume 34 (London: W. Pickering, 1850): 624. (622-627)

${ }^{148}$ T. Binney, “Short Essays,” The Evangelical Magazine and Missionary Chronicle, Volume V, New Series (London: Hodder and Stoughton, 1873): 575.
} 
The anti-Catholic reaction to the Universalis Ecclesiae was swift. In 1851, the Ecclesiastical Titles Act was passed to ensure that the Catholic Church did not restore pre-Reformation dioceses with Catholic bishops. It prevented Catholic encroachment on territorial titles and jurisdictions, thus forcing the Church to erect new ones. Likewise, there could not be a Catholic archbishop of Canterbury. Instead, the archdiocese of Westminster was created with its own archbishop. In like manner, the Archbishop of Westminster was not declared Primate of All England, though he and his successors always saw themselves as successors to Canterbury's Catholic archbishops. ${ }^{149}$ In Parliament, Lord Monteagle argued that the papal bull was issued with a "claim of authority, as if it were over the whole of the Queen’s subjects” rather than just the Roman Catholic population and Cardinal Wiseman's pastoral letter had done little to alleviate that impression. These measures were therefore necessary to preserve the Protestant order in England. ${ }^{150}$ The bull, he argued, was an act of aggression entirely unauthorized by the State and inconsistent with common law in England. ${ }^{151}$ The Earl of Winchilsea stressed the importance of restricting the Catholic Church in the "true interest of the country" in order to "uphold those principles upon which the constitution was founded, and by which England had obtained her greatness and freedom. ${ }^{152}$

The Ecclesiastical Titles Act reigned in the Catholic Church on a political level, but it did little to subdue the tension among the general populous. The immigrants brought the rhetoric, rituals, and habits of Catholicism to the cities, towns, and

\footnotetext{
${ }^{149}$ Victor Shea and William Whitla, Essays and Reviews: The 1860 Text and its Readings (Virginia: University of Virginia Press, 2000), 336-337.

${ }^{150}$ Lord Monteagle quoted in, The Parliamentary Debates (Authorized Edition) Volume 118 (London: H. M. Stationery Office, 1851), 1892.

${ }^{151}$ Ibid, 1476.

152 The Earl of Winchilsea, The Parliamentary Debates, 1220.
} 
neighborhoods across England, thus threatening the social fabric of the nation. Catholic Emancipation gave them access to the political system and their Church kept them isolated from English values. As the number of Catholics increased, so too did the number of schools and churches. These people did not send their children to be educated in English beliefs. Catholic children were not taught the values of freedom, constitutionalism, and civil liberty. They were taught to obey the pope in all respects, and as Cardinal Wiseman indicated, that even included the monarchy and Parliament. Catholic children were raised to remain outsiders to the English way of life and that meant this growing body of Irish immigrants would not and could not assimilate into English society. What impact would these huge numbers of immigrants have on England's socio-political structure as these people utilized their right to vote?

Protestantism was, for the English, a beacon of civility and England had taken that journey from superstition and darkness into liberty and light. ${ }^{153}$ In 1848 , Thomas Carlyle wrote that the history of England, from Ethelbert to the Reformation, was the "history of a struggle, ending with the complete victory of the laity." He argued that the earliest anti-national and hierarchic spirit of the early peoples of England were "gradually absorbed by the national lay spirit in which the rights of the citizen, the husband, and the individual conscience reigned supreme.” The battle for the souls of humanity was to be "fought in every Christian country and the married layman and the celibate priest may make truce for a time” but they were, in reality, “foes in grain.”154

\footnotetext{
${ }^{153}$ Michael Herbert, The Wearing of the Green: A Political History of the Irish in Manchester (London: Irish in Britain Representation Group, 2001), 36.

${ }^{154}$ Thomas Carlyle, “Why Should We Fear the Romish Priests?” Fraser's Magazine, Volume 37 (London: J. Fraser, 1848): 469.
} 
The anti-Catholic sentiment expressed in Parliament was brewing into something far more hostile on the streets. The Manchester and Liverpool areas in particular were becoming a hotbed of anti-Catholic activity in the wake of the Pope's announcement as these cities contained the largest population of Irish immigrants, but denouncements from the pulpit, the press and the meeting halls occurred elsewhere as well. Less than two months after the papal bull was issued, there was an anti-Catholic rally at the Manchester Free Trade Hall. Manchester anti-Catholic cleric Reverend Hugh Stowell delivered a lecture on papal aggression at the Free Trade Hall on 16th January $1851 .{ }^{155}$ He had always preached a fervent brand of fundamentalist Protestantism, denouncing Dissenters, Tractarians and Popery from the pulpit and from public platforms. Liverpool Reverend Hugh McNeile held frequent marches through the streets of the city seeking legal action against the Roman Catholic Bishops for crimes against the principles and values of the nation. ${ }^{156}$ Both religious leaders were firebrands who vowed to drive Catholicism from the shores of England by any means necessary. ${ }^{157}$

Other areas were also simmering with tension between the two religious groups. In 1835, a national Protestant Organization had formed to campaign for the repeal of Catholic Emancipation and against Catholicism in general, and local groups, such as the one in Stockport, became very active in local politics. Tory politicians such as Stockport Alderman Claye were members of their local Association as were Anglican clergymen, such as Stockport Reverend Meridyth of St. Peter's church. Meridyth was an Irish

\footnotetext{
${ }^{155}$ Edward R. Norman, Anti-Catholicism in Victorian England (London: Allen \& Unwin, 1968), 33.

${ }^{156}$ Norman, Anti-Catholicism in Victorian England, 70. See also: Frank Neal, Sectarian Violence: The Liverpool Experience, 1819-1917: An Aspect of Anglo-Irish History (Manchester: Manchester University Press, 1988)

${ }^{157}$ Brian Lewis, The Middlemost and the Milltown: Bourgeois Culture and Politics in Early Industrial England (Stanford: Stanford University Press, 2001), 204-205.
} 
Protestant who spoke at anti-Catholic meetings across the region, sometimes in the company of the firebrand Stowell. ${ }^{158}$ In Birmingham, religious leaders such as I.C. Barrett of St. Mary’s, J.C. Miller of St. Martin’s, and G.S. Bull of St. Thomas’ all held anti-Catholic rallies in their parishes and often spoke at one another's meetings. Reverend Hugh McNeile was even invited down from Liverpool to speak. In Northampton, an organization called the Northampton Religious and Useful Knowledge Society brought speakers such as Hugh Stowell to fan the flames of anti-Catholicism. ${ }^{159}$

\section{Anti-Catholic Sentiment Turns Violent}

This was the rhetoric that fuelled the anger on the streets as the fear of Catholic influence spread and then finally exploded into violence. On 15 June, 1852, three weeks before the general election, Lord Derby’s Tory government in Stockport issued a proclamation which forbade Catholics to walk in procession through the streets with the symbols of their religion. This was an obvious play to simmering anti-Catholicism amongst the public in order to sway the upcoming elections. ${ }^{160}$ The proclamation was issued twelve days before the event, but the nineteenth annual Sunday School procession by Stockport’s Roman Catholics went ahead as scheduled. On Sunday 27 June, 1852, local priests Randolph Frith of St. Philip’s and St James' and Robert Foster of St Michael's led local schoolchildren and Irish laborers through the streets as planned. No banners or Catholic emblems were carried and even the priests wore ordinary dress, not canonical vestments. ${ }^{161}$ Although there was no trouble on the procession itself, the streets

\footnotetext{
${ }^{158}$ Tony Claydon and Ian McBride, Protestantism and National Identity: Britain and Ireland, c.1650c.1850 (Cambridge: Cambridge University Press, 1998), 294.

${ }^{159}$ Denis G. Paz, Popular Anti-Catholicism in Mid-Victorian England (Stanford: Stanford University Press, 1992), 127.

${ }^{160}$ Herbert, The Wearing of the Green, 36.

${ }^{161}$ Donald H. Akenson, An Irish H istory of Civilization (London: McGill-Queen's Press, 2005), 82.
} 
were littered with inflammatory placards from the Orange Order urging Protestants against electing a Papist Parliament and encouraging them to put a stop to Romish aggression in any way possible. ${ }^{162}$

The following afternoon, however, an effigy of a priest was paraded through the streets by members of the local Protestant Association and later that evening fighting between Irish and English laborers began in the Bishop Blaize public house on Hillgate Street, one of the town's main streets. As the violence escalated, both the Irish and the English retreated to gather reinforcements. A short street brawl ensued and there was scattered vandalism, including broken windows at St. Peter's Schoolroom, but by the time the local police arrived it had died down. ${ }^{163}$

It flared up again a short time later and the local newspaper, the Stockport Advertiser, reported that the English followed the Irish "into their dwellings" and they were "dragged from their hiding places and their beds" while their furnishing and personal belongings were thrown into the streets. ${ }^{164}$ The Stockport police, the mayor and magistrates arrived as the last of the rioting died down. Sixty men from the Fourth Regiment of Infantry were also present and the Riot Act was read aloud. The disturbances ceased on the main streets, but the crowd did not disperse. They instead moved on to the Catholic Churches. The Manchester Guardian reported that the Chapel at Edgeley was ransacked and gutted. The priest's house and vestries adjacent to the chapel were also heavily damaged. Furniture was piled into the street and set ablaze. The Irish portion of the mob retaliated and attacked the house of Alderman Graham, a well-

\footnotetext{
${ }^{162}$ Pauline Millward, “The Stockport Riots of 1852,” in The Irish in the Victorian City, eds. Roger Swift and Sheridan Gilley (London: Croom Helm, 1985), 298.

${ }^{163}$ Paz, Popular Anti-Catholicism, 255.

${ }^{164}$ Stockport Advertiser, July 2, 1852.
} 
known Protestant and ransacked the Protestant church of St. Peter's and its schools. Like the commotion on Hillgate Street, the police arrived on both scenes well after the damage had been done. Once again, the Riot Act was read and the crowd finally dispersed. ${ }^{165}$

By Tuesday evening, twenty-four Irish homes had been heavily vandalized, and one Irishman, laborer Michael Moran, was dead from a blow to the head. ${ }^{166}$ Fifty-one Irish had been injured and two Catholic chapels had been nearly destroyed. Graham’s house and one Protestant Church had also sustained damage. The Manchester Guardian reported that there were 113 people in custody that were being charged with the brawl. 111 of those prisoners were Irish and two were English. The Guardian reported that most of the Irish prisoners were bandaged and bruised. ${ }^{167}$ Over the next several weeks, several more Englishmen were arrested and eventually ten Englishmen and ten Irishmen were formally charged. Three of the Englishmen and all ten of the Irishmen were found guilty of the crime of riot. ${ }^{168}$

The Stockport Riot was a destructive outburst of public aggression, but the verbal assaults on the Irish Catholics did not abate as the decade wore on. These people were clearly outsiders; troublemakers bent on destroying the social fabric of English society. On the first of July, Parliament made a query as to the cause of the riot. At the time, MP Walpole reported that the town mayor indicated it was too soon to ascertain the specific

\footnotetext{
165 Manchester Guardian, July 3, 1852.

${ }^{166}$ Herbert, The Wearing of the Green, 224.

${ }^{167}$ Manchester Guardian, July 3, 1852; Joseph Haydn, Haydn's dictionary of dates relating to all ages and nations: for universal reference (London: E. Moxon and Co., 1866), 622.

${ }^{168}$ Henry Heginbotham, Stockport Ancient and Modern, Volume One (1882), 104-106. Heginbotham wrote a thorough history of the town, including a detailed account of the large-scale riot of 1852. For further analysis of the Stockport Riot and the role of anti-Catholic societies in shaping public opinion see: John Wolffe, The Protestant Crusade in Great Britain: 1829-1860 (Clarendon Press, 1991); Donald M. MacRaild, Faith, Fraternity, and Fighting: The Orange Order and Irish Migrants in Northern England, $c$. 1850-1920 (Liverpool: Liverpool University Press, 2005); Richard Brown, Church and State in Modern Britain, 1700-1850 (Psychology Press, 1991).
} 
details, but "the disturbance appears to have arisen out of a quarrel between the English and Irish,” which, according to the mayor was driven by "religious animosity” between the two groups. ${ }^{169}$ This animosity filled the popular press. The Stockport Riot alone was featured in nine editions of the Manchester Guardian throughout the month of July, three editions of the Manchester Courier, and was referenced in Parliamentary debates throughout 1852 and 1853 repeatedly. ${ }^{170}$ In 1851, The Leader published a story that, according to the paper, reflected the true conniving spirit of the Catholic priests.

Mathurin Carré, a French immigrant, died leaving the sum of $£ 7000$ to the local Catholic diocese. According to the newspaper, an investigation revealed this was not entirely the truth. James Holstock, a local priest in Somerstown, called on the dying man just hours before he passed away. Witnesses claimed the priest held a pen in the man's hand and helped him sign a transfer for the very large sum of money. Once the transaction was completed, the household staff reported that the priest departed and the man then died without Last Rites or Confession. The article outlined the legal proceedings against the priest for having “forced the old man to give up his money without consent." ${ }^{171}$ In 1852, The Dublin University Magazine published a lengthy article on Ireland analyzing the nation's continued failure to thrive as a viable nation. The magazine blamed the "spiritual slavery" of a country riddled with priests under "spiritual despotism.”172 The article accused the Irish of blind obedience to the Church without consideration of loyalty to the monarchy or the United Kingdom and this submission allowed the Irish to commit

\footnotetext{
${ }^{169} \mathrm{Mr}$. Walpole cited in “The Stockport Riots,” House of Commons Debate, Volume 122, (July 1, 1852): 1430.

${ }^{170}$ Millward, “The Stockport Riots of 1852,” 220.

171 "Protestantism and Popery," The Leader, 2.50, March 8, 1851: 218.

172 “Ireland-Its Garden and Its Grave,” The Dublin University Magazine, 40:237, (September, 1852): 369
} 
“revolting crimes” against England without care or concern. ${ }^{173}$ Until the Irish abandon their slavish devotion to the Pope and Catholicism, “ignorance and superstition will be sufficient to blight even the fairest of lands." ${ }^{174}$ The Examiner stressed that it was vital to resist the encroachment of Catholic values and ideals "in the interest of civilization.” Should pro-Catholic candidates show respectable numbers in any elections, they would “disorganize parties” throughout England and “continue to trouble the political waters.” ${ }^{175}$ In 1854, Reverend John Lomas announced that he would never serve under the "Monarch of the Seven Hills" and he emphasized the important role of Protestant missionaries not only in their zealous fight against heathen faiths, but also in the battle against Catholicism. ${ }^{176}$

\section{The Early Pseudo-Sciences}

By the end of the decade, the anti-Catholic fervor had evolved into a broader negativity. During the 1850s, the first of the pseudo-scientific racial theories emerged, Phrenology, that stressed the connection between the physical characteristics and intellectual characteristics of entire races of people. This theory would not have its greatest impact until the 1860s, but it had its beginning amidst a massive anti-Catholic and thus anti-Irish sentiment. These others were now not only religiously backward, but they were also inferior on a much larger scope as well, an idea that will find immense support in the later half of the nineteenth century.

As articles in the English popular press began to reflect this more broad negativity toward the increasing population of Irish immigrants, Victorian culture responded in

\footnotetext{
173 Ibid, 369.

${ }^{174}$ Ibid, 373.

175 "Ireland Again in Extremes,” The Examiner, 2320, July 17, 1852: 451.

${ }^{176}$ John Lomas cited in, “Religious Intelligence,” Wesleyan Methodist Magazine, 10 (August, 1854): 747, 751-752.
} 
kind. The Preston Guardian simply argued that the Irish flooding into the country “diminished wages," became beggars "in our streets and highways," and choked "up the houses and offices of the relieving-officers of our poor law unions." ${ }^{, 177}$ The Manchester Times and Gazette reported that the "wretched hordes who now cover our streets with the exhibition of their misery” were taking jobs from hard working English laborers and only served to "pull [them] down to their own wretched level." The newspaper declared that "our Celtic brethren are... rapidly lowering the standard of decent comfort" among the English laboring class. There was, the article stated, "such a gregariousness and innate clinging to filth, such an ignorance of tidiness among these people, that they deteriorate everything." ${ }^{\text {178 }}$ Victorian slang became laced with negative Irish references. To 'go to an Irish wedding' meant one was going to clean a cesspool. 'Weeping Irish’ referred to insincere, feigned sorrow and 'getting up one's Irish' indicated a flagrant display of anger and aggression. ${ }^{179}$ It was rhetoric of this nature that, when fuelled by the racial ideologies of the next decades, created the image of the simian savage as represented in the political cartoons of the 1870s and 1880s.

In an 1829 report on Irish vagrancy, an anonymous witness before the House of Commons predicted that the "evils likely to result to the labouring classes of England from the increasing corruption of the Pauper population of Ireland,” will be a bane future generations would bear if the problem was not addressed immediately. ${ }^{180}$ John Ramsay McCulloch argued that the Irish brought "pernicious consequences” to the people of

177 “Condition of Ireland,” The Preston Guardian 1791, December 24, 1846.

178 "Legal Provisions for the Poor,” The Manchester Times and Gazette 1847, March 19, 1847.

${ }^{179}$ L.P. Curtis, Anglo-Saxons and Celts: A Study of Anti-Irish Prejudice in Victorian England (Connecticut: University of Bridgeport, 1968), 52.

${ }^{180}$ Great Britain, Report from the Select Committee on the Laws Relating to Irish and Scotch Vagrants (July 7, 1829), 513. 
England as the "blood and character of the people" were a "contaminating influence" that threatened to degrade the English as the nation was "overrun by a pauper horde." ${ }^{181}$ To the average Englishman, this prophecy was not only true, but by the end of the 1850s, those evils had permeated the middle class as well. For a time, the Irishman was the subject of pity, and perhaps the negativity would not have intensified had he remained in his own country. Instead, because of the growing crisis, millions fled and became a threat to the social and economic order once they crossed the Irish Sea to England. Immigration was never supposed to be "bands of paupers of merely seeking to run from hunger in one land, into utter... desolation in another," but to the English public that is what indeed was occurring across their nation. ${ }^{182}$ The famine had left England with a diseased, Catholic blight on their hands, and like the potato blight of the famine itself, threatened to upend the entire social and political order of English society

\footnotetext{
${ }^{181}$ John Ramsay McCulloch, A Descriptive and Statistical Account of the British Empire: Volume I (London: Longman, Brown, Green, and Longmans, 1854), 395.

182 "Condition of Ireland," The Preston Guardian 1791, December 24, 1846.
} 


\section{Chapter Five}

\section{The Irish Other: A Convenient Truth}

Historian Kevin Kenny, in his work Ireland and the British Empire argues that the term colony traditionally conjured images of imperial possessions in far-flung exotic lands marked by extreme racial subjugation. The Irish, therefore, present a problematic thorn in this image as they lacked the required distance, but by the 1860s, the English popular press began casting them as a racially inferior, feminized group much like the distant, exotic peoples over which they ruled around the globe. ${ }^{1}$ Anger over Chartist violence meshed with frustration over the economic and social fallout from the famine and eventually hatred flared over the ever increasing problems the Irish brought to England as they fled their own country in droves. Had this situation remained static, perhaps the Irish would have eventually faded from public view as the crises subsided. By the 1860s, however, scientific racism, which had gained adherents in the intellectual communities, began to filter down to the public and added a new layer of meaning to the tragedy of the Irish. The hatred toward the Irish immigrants evolved from a purely emotional reaction into something far more intractable. The English now had reasons for their views based on Darwin and others scientists of the time. This scientific racism, as it has come to be known, became justification for the continued repression and growing malice toward the Irish people in the later nineteenth century. ${ }^{2}$

The tumultuous relationship between the Irish and the English that began under Henry II in the 1100s had always been punctuated by certain critical factors. First, Ireland

\footnotetext{
${ }^{1}$ Kevin Kenny, Ireland and the British Empire (England: Oxford University Press, 2004), 2.

${ }^{2}$ Benedict Anderson, Imagined Communities (New York: Verso Books, 2006), 150.
} 
was a separate geographical body from England and thus the people remained divided by the Irish Sea. Second, Ireland was a colonial holding and thus remained divided by England politically as well as physically. After the Act of Union, however, the second distinction was eradicated and as poverty and famine became the norm in the early decades of the 1800s, the first distinction began to vanish due to immigration. As the decades progressed, the turmoil of the Irish problem continued to plague England through their involvement in Chartism and radical politics. The Great Famine escalated immigration into England, bringing the two cultures in closer proximity as the Irish flooded urban areas. These immigrants brought disease, poverty, degradation, and social disorder to the English socio-political structure and by the 1860s the Irish infection had become too much. These immigrants were isolated from the larger whole as the other, racially distinct from the English and clearly inferior. Historian Ludmilla Jordanova, in her work Sexual Visions: Images of Gender in Science and Medicine between the Eighteenth and the Twentieth Centuries provides a useful, concise definition for the concept of the other. The other is an object, something to be "managed and possessed" as it is dangerous and threatening to the status quo. Yet at the same time, this dangerous entity, in its separateness and uniqueness, invites curiosity. Science, Jordanova posits, seeks to define, classify and "unveil" the mysteries of the other in order to protect the status quo. ${ }^{3}$ By the 1860s, all attempts to prevent the Irish other from infecting England's status quo had failed. Instead, Victorian society turned to science and the Irish became the hated foreigner inside English borders.

\footnotetext{
${ }^{3}$ Ludmilla Jordanova, Sexual Visions: Images of Gender in Science and Medicine between the Eighteenth and the Twentieth Centuries (Brighton: Harvester Wheatsheaf, 1989), 109-110.
} 


\section{The Origins of Race as a Classification}

Prior to the 1800s, the word 'race' was rarely used. Its only application was as a simple classification term, such as 'kind,' 'type,' or 'stock,' and the meaning was somewhat vague. ${ }^{4}$ During the mid-1800s however, new philosophies came to the forefront in European scientific theory. As early as the 1100s the English began expanding their empire, and over the centuries, they encountered a wider variety of peoples with diverse cultures, thus gradually developing attitudes and beliefs that reflected a new interpretation of human differences. ${ }^{5}$ The concept of race began to shift as ideologies emerged that added human perspectives to older definitions formally reserved for the animal kingdom. Race was so pervasive in this period that the conceptual framework cannot be traced to any single source, be it author, statesman, or social group. Evolving from a myriad of sources, the term eventually became a metalanguage in English discourse, shaping socio-political structures through its new application. These new dimensions tightened the parameters of a once vague term to include social meanings that were imposed on physical variations in order to structure society. The mental construct of the term race was now inextricably linked human identity, thus becoming a biological entity in order to fix external meanings to genetic differences, and these ideologies were impervious to reason, arguments or logic as they became encoded into the everyday life of Victorian England. ${ }^{6}$

\footnotetext{
${ }^{4}$ Audrey Smedley, “'Race' and the Construction of Human Identity,” American Anthropologist, New Series Vol. 100 No. 3 (September 1998): 694.

${ }^{5}$ Michael Banton, Racial Theories (Cambridge, Cambridge University Press, 1987), xi.

${ }^{6}$ Ibid, 693; Steve Martinot, The Rule of Racialization: Class, Identity, Governance (Philadelphia: Temple University Press, 2003), 131; Douglas Lorimer, "Race, science and culture: historical continuities and discontinuities, 1850-1914," in The Victorian and Race, ed. Shearer West (England: Scolar Press, 1996), 13.
} 
The middle class of England began to separate, divide, and classify groups of people in order to construct hierarchies. Differences in bodily characteristics became associated with social categories, thus transforming those differences into racial signifiers rather than simple descriptive terms. ${ }^{7}$ This social hierarchy could then be used to define not only an individual, but an entire nation or ethnic group. ${ }^{8}$ The English could now distinguish themselves from their barbaric neighbors; and thus preserve a national identity based on the superior Anglo-Saxon civilization. Using these racial hierarchies, the English could construct what Graham MacPhee and Prem Poddaer call the internal identity of the British Empire. The internal identity was local, distinctly English and rooted in Anglo-Saxon tradition. English was defined by not only by what it was, but by what it was not. The Celtic identity served as that racial foil. Britishness, according to Macphee and Poddaer, was the external, imperial identity applicable to both the core and the periphery of the British Empire. English, however, was the exclusive identity of the core. England, and Englishness, was the heart of the empire. ${ }^{9}$ Author and politician Charles Wentworth Dilke expressed the Victorian representation of this internal identity when he argued that "by Greater Britain we mean an enlargement of the English state... it carries across the seas not merely the English race, but the authority of the English government.” He stressed that the "English Empire in the main and broadly may be said to be English throughout. ${ }^{10}$ Long before postcolonial theory identified a distinct

\footnotetext{
${ }^{7}$ Ibid, 180 and Michel Foucault, The Order of Things: An archaeology of the Human Sciences (New York: Vintage Books, 1973), 135-136.

${ }^{8}$ Michael Banton, Racial Theories (Cambridge: Cambridge University Press, 1987), xvi.

9 "Introduction," Empire and After: Englishness in Postcolonial Perspective, eds. Graham MacPhee and Prem Poddaer (New York: Berghahn Books, 2007), 3.

${ }^{10}$ Charles Wentworth Dilke, Greater Britain: A Record of Travel in English-Speaking Countries during 1866 and 1867 Volume II (London: MacMillian and Co., 1868), 42, 47.
} 
difference between the concept of English and British, the English people considered

themselves a distinct race, unique from the others across the growing empire.

\section{The Pseudo-Sciences, The Anglo-Saxon and the Celt}

The term Saxon is an ancient ethnic identification applied to the people of

England from as early as the 400s and they were one of many groups found on the island. ${ }^{11}$ England's history is replete with invasions, from the Romans to the Saxons to the Normans, thus negating any argument for a racially pure English people. As

England's empire grew, however, contact with other cultures increased and the English began to seek ways to separate themselves from these lesser peoples. ${ }^{12}$ Their neighbors, both France and Ireland, provided the most immediate point of contrast. Both countries were Catholic and Celtic according to the beliefs of the period, while the English, with their ancient Saxon pedigree, represented the height of superiority throughout Europe. ${ }^{13}$

As English historians attempted to define modern history throughout the eighteenth and early nineteenth century, this ethnic division became an easy framework in which to set their arguments. In 1841, Thomas Arnold, a prominent professor of Modern History at Oxford University, argued that the modern history of Europe began when four dominant

\footnotetext{
${ }^{11}$ See Chapter One for a thorough discussion of the Annals of Ireland and the delineation between the native population of Ireland and the 'Saxon' foreigners from across the sea in Britain.

${ }^{12}$ For further analysis of the relationship between the metropole and the periphery see: Catherine Hall, Civilizing Subjects: Metropole and Colony in the English Imagination 1830-1867 (Chicago: University of Chicago Press, 2002); Anne McClintock, Imperial Leather: Race, Gender, and Sexuality in the Colonial Context (London: Routledge, 1995).

${ }^{13}$ H. MacDougall, Racial Myth in English History: Trojans, Teutons, and Anglo-Saxons (Canada: Harvest House, 1982), 89. During the 1860s, there were a number of publications highlighting the myth of the Anglo-Saxon. See: Charles Kingsley, Hereward the Wake: The Last of the English (London: Macmillan, 1866) for an analysis of the Saxon leader Hereward and his valiant fight against the Normans. Kingsley also published The Roman and The Teuton: A Series of Lectures that argued for the supremacy of the Saxon blood as the origins of Protestant masculinity in contrast to Roman decadence and weakness. John Earle, professor of Anglo-Saxon, published numerous texts through Clarendon Press in Oxford on the Anglo-Saxon heritage. In 1867, William Theed's statue of Queen Victoria and Prince Albert in AngloSaxon dress was erected in the Royal Mausoleum at Frogmore in honor of their ancient bloodline (fictitious as it might have been). For a greater analysis of the relationship between France and England see Linda Colley, Linda Colley, Britons: Forging the Nation, 1707-1837 (New Haven: Yale University Press, 1992).
} 
features of powerful nations began to control socio-political discourse. These four elements were race, language, institutions and religion. Race, according to Arnold, was the blood of a people and, along with the other three components, defined a nation and its history. ${ }^{14}$ Arnold stressed that of all the peoples of Europe, it was the Germanic peoples that had the most powerful impact on the development of the modern nations. ${ }^{15}$ It was, he argued, the fusion of the Roman with the Anglo-Saxon that led to the annihilation of the inferior Gaul in France and brought the civilizing light of liberty and Protestantism to northern Europe. ${ }^{16}$ The Anglo-Saxons were the vanguards of progress throughout the ages and although England's language was not German, the English blood and institutions were "German mostly decidedly." ${ }^{17}$ Without hesitation, he stated that "our English race is the German race” and it was this race that changed the face of Europe. ${ }^{18}$ Any modernity that existed across England's colonial realm was the result of AngloSaxon endeavors because the native populations were too limited in their abilities. The inferior races, such as the Celts of Europe and the aboriginal tribes in the colonies, had but two choices: submit to the domination of the superior Germanic peoples or face extinction. ${ }^{19}$ Arnold's analysis of modern history became the standard at Oxford and thus the framework for intellectual historical discourse across England. ${ }^{20}$ It was this AngloSaxon perception of England that filtered down to the middle class through the popular

\footnotetext{
${ }^{14}$ Thomas Arnold, Inaugural Lecture on the Study of Modern History (Oxford: Parker, 1842), 27-41.

${ }^{15}$ Ibid, 34-35.

${ }^{16}$ Ibid, 36-41.

${ }^{17}$ Ibid, 35.

${ }_{18}^{18}$ Ibid, 33-34.

${ }^{19}$ Ibid, 200-201.

${ }^{20}$ For further analysis of Arnold's impact on the education system of England see: United States. Office of Education, Report of the Federal Security Agency: Office of Education Volume I (United States Government Printing Office, 1900); Arthur Penrhyn Stanley, The Life of Thomas Arnold (New York: read Books, 2007); David Ian Allsobrook, Schools for the Shires: the reform of middle class education in midVictorian England (Manchester: Manchester University Press, 1988).
} 
press and by the 1860s helped provide the racial distinction between the English bloodline and the Celtic Irish bloodline.

The concept of Anglo-Saxon racial superiority was a gradual development, becoming more scientific in the nineteenth century with the development of Phrenology. This new science, developed by German physician Franz Joseph Gall in 1796, argued that human personality traits could be determined by examining the bumps and ridges of the head. Phrenologists believed that each portion of the brain served a unique function in determining personality and the cranial bones of each individual grew to accommodate these sections. Every skull would, therefore, have slightly different measurements that related to the size of each section in the brain. They also stressed that entire populations of people had similar measurements, and thus head size and shape could be used to determine characteristics common to particular races. Phrenologists also argued that these groups could be classified developmentally as well as physically. Physical characteristics, such as skull size or distance between the eyes, were leading indicators of the developmental capabilities of a people and, according to leading phrenologist George Combe, the size of the brain in general was the "measure of power" in each individual. ${ }^{21}$ Supporters argued that there was a "rough correspondence between ... grade of intelligence or civilization and the size of [the] brain.” Phrenologists believed that it could be taken for granted that "all the lowest races have foreheads villainously low" and that the civilized, more cultivated races "have, on the average, high, full, and deep foreheads."22 Savage races, round-headed, dark haired "prognathous types,” were closer

\footnotetext{
${ }^{21}$ George Combe, Lectures on Phrenology (New York: Samuel Colman, 1839), 24.

22 “The Human Face Divine,” New Quarterly Magazine, 2 (July, 1879): 170.
} 
to the animal, while the superior races were blond and of the "dolochocephalic type.”23 These savages, according to phrenologists, had no faculties higher than sensuality, cunning, covetousness, cruelty and pride. These categories and their related personality traits were the accepted science of the day. ${ }^{24}$ The very destiny of races, according to phrenologists, could be linked to their "physical structure in general, and the cerebral conformation in particular."25

Phrenology spread quickly in England in part to Gall's collaborator Johann Spurzheim, publisher Robert Chambers, and George Combe and by 1836 there were twenty-nine official Phrenological Societies registered in Great Britain. ${ }^{26}$ John Van Wyhe, a historian of science, argues that the Victorian Era, like the Renaissance, was an explosion of knowledge, learning and progress. The Industrial Revolution, according to Wyhe, is often the focus of the period in terms of innovation, but science also made rapid developments. The mass production of printed material brought this knowledge to the growing middle class who was eager to delve into the new developments of the day. As Chambers used his publishing connections to push Phrenology it spread among the popular culture in England. ${ }^{27}$

It was, however, only the first step in the development of the racial ideology of the 1800s. With the release of Darwin's groundbreaking work on evolution, Origin of the

\footnotetext{
${ }^{23}$ Nancy Stepan, The Idea of Race in Science: Great Britain 1800-1960 (Connecticut: Archon Books, 1982), 101.

${ }^{24}$ Owsei Temkin, "Gall and the Phrenological Movement," "On Second Thought" and Other Essays in the History of Medicine and Science (Baltimore: John Hopkins University Press, 2001), 302 and Curtis, Apes and Angels, 1-22.

25 "Ethnology and Phrenology,” London Review of Politics, Society, Literature, Art and Science 7:165 (August, 1863): 232.

${ }^{26}$ George Combe's work A System of Phrenology was so popular it went through four editions in England and was published across the continent and in the United States.

${ }^{27}$ John Van Wyhe, Phrenology and the Origins of Victorian Scientific Naturalism (London: Ashgate Publishing, Ltd., 2004), 1-2.
} 
Species in 1859, taxonomies of human hierarchies quickly evolved into scientific racism.

Scientists of the late 1800s argued that the "closest resemblances between men and monkeys should occur between the lower races of the former and the highest of the latter. ${ }^{28}$ Darwin argued that declining fertility rates among the lesser, savage races would lead to their likely extinction. These lower races, with their smaller brains, were unable to adapt and evolve when brought into contact with the higher, more civilized races and they would eventually die off naturally. ${ }^{29}$ Breeding 'good stock' to ensure the survival of the fittest thus became the moral imperative of the civilized classes, and all good citizens had, as Francis Galton argued, to "try to render our individual aims subordinate to those which lead to the improvement of the race” because from his perspective, race was "far more important than nurture" as it created superior individuals who then became the basis for superior nations. ${ }^{30}$ It was the responsibility of these superior men to "leave the greatest number of progeny" possible in order to continue to advance the "gifted families," thus creating the backbone of a powerful nation. ${ }^{31}$ The ultimate goal, after generations of controlled breeding, was the development of a “selected race” who would then dominate the inferior species on a global scale. ${ }^{32}$

\section{Race as an Imperial Tool}

The Anglo-Saxons of Europe were defined as the superior race, and it was in the best interest of the world to see their bloodlines dominate over the inferior. Scottish anatomist and lecturer, Robert Knox, one of the most influential advocates of racial

\footnotetext{
28 "Our Simean Cousins," Chamber's Journal of Popular Literature, Science and Arts, 12:621 (November, 1895): 751.

${ }^{29}$ Charles Darwin, The Descent of Man (London: D. Appleton and Co., 1871), 228.

${ }^{30}$ Francis Galton, “Hereditary Improvement,” Fraser’s Magazine, 7:37 (January, 1873): 120, 116.

${ }^{31}$ Francis Galton, "Measurement of Character," Fortnightly Review, 3:212 (August, 1884): 95 and Galton, "Hereditary Improvement," 125.

${ }^{32}$ Galton, "Hereditary Improvement," 127.
} 
determination, argued as early as 1850 that "race is everything: literature, science art - in a word civilization - depends on it." ${ }^{33}$ Knox sought to convince the public that the various European peoples were in reality, distinct races that were in perpetual conflict because of biologically determined human nature that defined national characteristics. Rejecting the concept of environmental influences on the individual, he argued that the unique qualities of each race explained the wide disparity in living conditions rather than adaptation to varying environments. ${ }^{34}$ Superior races developed superior socio-political and economic structures while the inferior failed to thrive and needed to be controlled. Failing that, the inferior could be eliminated. He published numerous books, pamphlets and articles on the subject and attracted a considerable following of students, many of whom then went on to become physicians and comparative anatomists and thus helped to shape scientific thought. One such student, James Hume, later co-founded the Anthropological Society of London in 1863 and publicly supported Knox’s views on race, character, and identity. Like Knox, historian and journalist Goldwin Smith also believed in the primary power of race. In a lecture before the Oxford Architectural and Historical Society’s Annual Meeting in 1861, he stressed that “of the physical influences which affect the character and destiny of nations, the most important seems to be that of race. ${ }^{35}$ Sir Charles Dilke, author and politician, also reflected upon the struggle of what he termed the 'dear' races against the inferior, and he predicted that "the dearer are on the whole, likely to destroy the cheaper peoples ... Saxondom will rise triumphantly from the

\footnotetext{
${ }^{33}$ Robert Knox, The Races of Men: A Fragment (London: Lea \& Blanchard, 1850), 7.

${ }^{34}$ Robert Knox, The Races of Men: A Philosophical Inquiry into the Influence of Rae over the Destinies of Nations, Second Edition (London: Henry Renshaw, 1862), 14.

${ }^{35}$ Goldwin Smith, Irish History and Irish Character (London: J.H. and Jas. Parker, 1862), 5.
} 
doubtful struggle.” He, like Galton, also argued that the "gradual extinction of the inferior races is not only a law of nature ... but a blessing to mankind.”36

If these inferior peoples were not eliminated, then the second course of action was subjugation and domination. The Anglo-Saxon, according to historian and Fraser's Magazine editor James Anthony Froude, lived near peoples “created infinitely unequal in ability and worthiness of character" and it was this lowliness that gave England the "natural right to govern" over them. The ignorant and inferior of the world, Froude argued, should be” compelled for their own advantage to obey a rule which rescues them from their natural weakness.”37 Galton argued that “constitutional stamina, strength, intelligence and moral qualities cling to a breed,” thus giving justification to the hierarchy of power that emerged from imperialist conquests. ${ }^{38}$ Britons came to believe that their contact with the savage races across the globe was actually beneficial to those races, raising the standards of the lower peoples and bringing advantages to underprivileged regions.

This ability to conquer barbarism, and spread the light of civilization, was, for the English, tied to their Anglo-Saxon roots. Using concepts drawn from Phrenology, the English clearly defined racial superiority as Anglo-Saxon blood. Noted phrenologist George Combe praised the Caucasian Anglo-Saxon above all other races. "The inhabitants of Europe, belonging to the Caucasian variety of mankind,” wrote Combe, "have manifested, in all ages, a strong tendency towards moral and intellectual improvement.” He argued that the Anglo-Saxon race in particular "has been richly

\footnotetext{
${ }^{36}$ Sir Charles Dilke, Great Britain: a record of travel in English-speaking countries during 1866 and 1867, Volume II (London: Macmillan, 1868), 405, 130.

${ }^{37}$ James Anthony Froude, The English in Ireland in the Eighteenth Century (London: Longmans, Green and Co., 1872), 2.

${ }^{38}$ Galton, "Hereditary Improvement," 117.
} 
endowed by nature with mental abilities,” while the Celt lagged far behind his Teutonic neighbor. ${ }^{39}$ Saxons were physically tall, "the strongest, as a race, on the face of the earth" and the "unspoiled Englishman” was considered the "healthiest, most energetic and enduring being” across the globe. ${ }^{40}$ The intellectual region of the Saxon brain was “massive,” and this gave the race a confidence, brilliance, and high self-esteem distinctly lacking in the lower of the species. ${ }^{41}$ These traits, according to racial theories of the day, put the Anglo-Saxon in a better position than any other race to "work out to the highest advantage all the capabilities of any country, wherever climate permits the exercise of his wonderful energies.”42 Historian, teacher, and social commentator Thomas Carlyle argued that it was the Saxon English that were "declared by Nature and Fact to be the worthier, and will become proprietors" on a global scale and this, he stressed, was "the law... for all lands in all countries."43

\section{Social Darwinism}

Social Darwinism extended the ideology rooted in the physical analysis of Phrenology. Stemming from the work of Francis Galton, Herbert Spencer, Thomas Malthus and others, this theory argued that like the animal kingdom, competition among

\footnotetext{
${ }^{39}$ George Combe, "Phrenological Remarks on the Relation between the Natural Talents and Disposition of Nations, and the Development of their Brains,” in Samuel G. Morton’s Crania Americana (Philadelphia, 1939), 271.

${ }^{40}$ Robert Knox, The Races of Men: A Philosophical Inquiry into the Influence of Race over the Destinies of Nations (London: Henry Renshaw, 1962), 50 and “Art. VIII.- The Social Sores of Britain,” North British Review 47:94 (October, 1867): 497.

${ }^{41}$ Richard Tuthill Massy, Analytical Ethnology: The Mixed Tribes of Great Britain and Ireland Examined, and the Political, Physical and Metaphysical Blunderings on the Celt and Saxon Exposed (London: H. Bailliere, 1855), 13.

${ }^{42}$ George Ellis, Irish Ethnology Socially and Politically Considered; Embracing a General Outline of the Celtic and Saxon Races; with Practical Inferences (London: Hamilton, Adams and Co., 1852), 24.

${ }^{43}$ Thomas Carlyle, “Occasional Discourse on the Negro Question,” Fraser's Magazine 40 (December, 1849): 674. Expanded and reprinted as a separate pamphlet titled, Occasional Discourse on the Nigger Question (London, 1853).
} 
all individuals, groups, nations, or ideas drives social evolution in human societies. ${ }^{44}$ Galton's work in particular applied the term Darwinism to a larger scope of development, thus creating a mechanism for social adaptation that was similar to Charles Darwin's theory of natural selection. According to the theory of natural selection among humans, if the Teuton was so physically superior, then it was reasonable to assume he should also be spiritually, socially, and culturally superior. Social Darwinists argued that facts did indeed bear out this simple line of logic. Protestantism and a democratic government founded in liberty were both brought to fruition by the Anglo-Saxon race. Arguing that Catholicism was "contrary to the inner genius of the Teutonic race, with its independence, its self-will, [and] its free will,” the Anglo-Saxon was destined to break the bondage of the Catholic Church. ${ }^{45}$ The Church of England was "wonderfully and mysteriously fitted for the souls of a free Norse-Saxon race," unlike the rigid structure of priestly control under Catholicism. ${ }^{46}$ As an enlightened people, the English offered “every possible conciliation” to the Catholic Church in Ireland, yet it sought “total and complete supremacy” as a dictatorship over not only its own people, but those in England. ${ }^{47}$ The Protestant faith, however, seeped in "individualism, willfulness, self reliance, [and] independence” gave England its foundation for greatness. ${ }^{48}$ The Saxons, as the "professors of the reformed religion,” had embraced the true faith of Protestantism, bringing prosperity and enlightenment to the British Isles and deposing of the tyranny of

\footnotetext{
${ }^{44}$ For further analysis of Social Darwinism see: Michael Hawkins, Social Darwinism in European and American Thought, 1860-1945 (Cambridge: Cambridge University Press, 1997).

${ }^{45}$ Isaac Taylor, The Origins of the Aryans: An Account of the Prehistoric Ethnology and Civilisation of Europe (Scribner and Welford, 1890), 94. The term Anglo-Saxon, Teuton, and Aryan were often used interchangeably during the 1800s.

${ }^{46}$ Charles Kingsley as quoted in Frederic Everett Faverty, Matthew Arnold, The Ethnologist (Evanston: Northwestern University, 1951), 108.

${ }^{47}$ Lord Elcho, “Committee,” House of Commons Debate, Vol. 191 (April 30, 1868): 1666.

${ }^{48}$ Taylor, The Origins of the Aryans, 247.
} 
popish domination. ${ }^{49}$ This attitude reflected a new racial dimension to the anti-

Catholicism from the prior decade. Now not only was the Catholic faith simply backward and seeped in ignorance, but it was now the mark of inferior races as well.

Just as they broke the chains of the priests, so too did the Anglo-Saxons spearhead the concept of freedom through democratic government. As the "only race that truly comprehends liberty,” the Anglo-Saxon defined liberty and respect for the rights of English men and women as fundamental to English society. ${ }^{50}$ The individualism and genetic drive for liberty that drove the papists from English shores were also responsible for the remarkable creation of constitutional monarchy. As a race of enlightened individuals, democratic by nature, the Anglo-Saxon could "preserve order and stability" better than other races, and this ability laid the foundation for democracy in Europe. ${ }^{51}$ These advancements were all racial characteristics of the "unspoiled Englishman” who was "the strongest, healthiest, most energetic and enduring being on the face of the earth." ${ }^{52}$ The Anglo-Saxon, according to Joseph Chamberlain and other patriotic Englishmen, had a “destiny” of global domination reserved exclusively for him because his stock was "proud, persistent, self-asserting and resolute" and was, by nature inherently superior. ${ }^{53}$

\footnotetext{
${ }^{49}$ George Ellis, Irish Ethnology Socially and Politically Considered: Embracing a General Outline of the Celtic and Saxon Races; with Practical Inferences (London: Hamilton, Adams and Co., 1852), 20 and R.B. O’Brian quoted in Luke Gibbons, "Race Against Time: Social Discourse and Irish History,” ed Catherine Hall (London: Routledge, 2000), 44-45.

${ }^{50}$ Knox, The Races of Men, 46; Geoffrey Elton, The English (Oxford: Blackwell, 1992), 235.

${ }^{51}$ Knox, The Races of Men, 46.

52 “Art. VIII. - The Social Sores of Britain,” North British Review, 47:94 (December, 1867): 497.

${ }^{53}$ Wolfgang Mock, "The Function of Race in Imperial Ideologies: The Example of Joseph Chamberlain," Nationalist and Racist Movements in Britain and Germany Before 1914, eds. Paul Kennedy and Anthony Nicholls (Oxford: St. Anthony's College Press, 1981), 195. The racial ideology of the Anglo-Saxon, as defined by Chamberlain, Carlyle and others, excluded any mention of the Normans, Romans, or Celts who had inhabited England at various points and were as integral to the culture, history and bloodlines of England as the Anglo-Saxon tribes of Germany.
} 


\section{The Celtic Other}

Based on the racial theories of the era, the Anglo-Saxon and the Celt were too distinct, too racially different to find common ground. Scientists of the time believed wholly in the superiority of the Anglo-Saxon, but they also needed to define the other by highlighting deficiencies and differences. Racial theory gave the English the scientific ground to categorize not only what was superior, but also what was inferior. Phrenology classified the Irish features as of "the most repulsive kind," and catalogued racial characteristics such as "projecting jaws, large open mouths, depressed noses, and bow legs;" all marks of a "low and barbarous condition." ${ }^{54}$ Thomas Carlyle argued that there were only a few types of physiognomies for the Irish face because they were "servants," and their faces reflected an "air of faculty misbred.” Some had the "bland big tiger face," while others reflected a more "angry and bewildered" expression, and both were marked by a significantly low intelligence. ${ }^{55}$ Concurring with Carlyle, English economist and travel writer Nassau William Senior observed the “unintelligent faces” of the Irish natives and expressed an intense dislike for a people "so ignorant, so prejudiced, and so illogical." ${ }^{56}$ In her travel diaries, English aristocrat Theresa Cornwallis Whitby West stated that the Irish "were not a handsome race" with "hair disheveled, feet bare and disgustingly dirty" and she found them overall to be "dark-eyed, elf-locked, and paleskinned ... rarely beautiful., ${ }^{57}$ These people displayed clear defects, and distinct marks of inferior breeding, thus serving as a physical foil to the superior beauty and structure of

\footnotetext{
${ }^{54}$ Robert Chambers, Vestiges of the Natural History of Creation 1844 (New York: Humanities Press, 1969), 280.

${ }^{55}$ Thomas Carlyle, Reminiscences of My Irish Journey in 1849 (New York: Harper and Brothers, 1882), $210,19-20$

${ }^{56}$ Nassau William Senior, Journals, Conversations and Essays Relating to Ireland: Volume Two (London: Longmans, Green and Co., 1868), 29, 167, 178.

${ }^{57}$ Theresa Cornwallis Whitby West, A Summer Visit to Ireland in 1846 (London: R. Bentley, 1847), 47, 5, 59.
} 
the Anglo-Saxon form. Poverty, it was believed, reduced the quality of the human stock, imbuing the lower classes with "bad constitutions and invalidism," and there was no lower than the Irish. ${ }^{58}$ The Derby Mercury reported that there were "scarcely any two nations under the sun whose representative individuals present such striking mental and physical contrasts as those of England and Ireland.”59

As the popularity of phrenology and polygenics faded in the 1860s, Darwinism rose in its place as a more scientific theory grounded in better research. The Social Darwinists could now attribute the physical defects of the Irish to a complex scientific theory. If Man did indeed evolve from apes, would it not stand to reason that some races were closer to the ape than others? Social Darwinism became the scientific framework to explain cultural differences, and the Irish, as an inferior race, were quickly classified “more like squalid apes than human beings.”60 Novelist Charles Kingsley described being “haunted by the human chimpanzees” he saw across Ireland during his travels. ${ }^{61}$

The symbolism of the ape beast was just one facet of Social Darwinism. Intellectual arguments, grounded in research and analysis, confirmed the hierarchical inferiority of the Irish. The East, according to scholars of the day, was less-developed on the Darwinian scale than the culture of the West. Eastern peoples were not as advanced and their languages, religions, and cultures were centuries behind the Western nations. There was, therefore, the natural assumption that the Irish must be “Asiatic in an European latitude and on an European soil.”62 This was the only reasonable explanation

\footnotetext{
${ }^{58}$ Francis Galton, “Hereditary Improvement,” Fraser’s Magazine 7:37 (January, 1873), 118.

59 The Derby Mercury (December 1, 1867).

60 J.A. Froude quoted in Anglo-Irish Relations, 1798-1922, Nick Pelling (London: Routledge, 2003$), 46$.

${ }^{61}$ Charles Kingsley, His Letters and Memories of his Life, ed. Francis E. Kingsley III (London: MacMillan, 1901), 17.

${ }^{62}$ Editorial, The Times, February 22, 1847.
} 
for the inherent conflict in these people, white yet so backward when compared to the Anglo-Saxon. ${ }^{63}$ The Irish people simply could not have any links to the Teuton, but instead bore a "stronger affinity to [the character] of the Bengalese or the Cingalese.”64 Their bloodlines, according to researcher Charles Hamilton Smith, came directly from the East, and the foundations of their pre-Christian language and religion had direct ties to the ancient civilizations of India and Persia. ${ }^{65}$ Theresa Cornwallis Whitby West, in her studies of the round towers dotting the Irish countryside, argued that they were of “Eastern and Pagan origin” closer in design to the Taj Mahal and Indian architecture than to anything in the West. ${ }^{66}$ By connecting the Irish to the East, the British were able to further distinguish the blood of the Celt from that of the Anglo-Saxon. The Teuton, born on Western European soil, was the peak of human evolution. In contrast, the Celt was clearly the opposite, the symbolic foil to this superior race as the bestial primitive from the East.

During the 1800s, the symbolic image of 'savage’ began to permeate Social Darwinism, expanding upon the more general concepts of inferior characteristics. The image of 'savagery' during this period was another facet of the theories explaining inherent human differences, and these ideological differences became embedded in English society and thought. The English began to view the Irish as a savage race, one more addition to the list of inferior characteristics of the other. Their clannish nature gave them a tendency toward "factions and open war," while their "vicious" nature prevented

\footnotetext{
${ }^{63}$ Editorial, The Times, February 22, 1847.

${ }^{64}$ Editorial, The Times, February 25, 1847.

${ }^{65}$ Charles Hamilton Smith, The Natural History of the Human Species (London: W.H. Allen and Co., 1848), 431.

${ }^{66}$ West, A Summer Visit to Ireland, 19-22.
} 
them from ever progressing toward any higher civilization. ${ }^{67}$ Popular articles described the Irish as a “desperate race” capable of seeking violent retribution, irrationality, and murder when it suited their ends. ${ }^{68}$ Satirical cartoonist Joseph Kenny Meadows depicted them as violent, bestial and diabolical in an 1843 drawing titled, The Irish Frankenstein. ${ }^{69}$ They managed their affairs more by "rage and fury than by reason.”70 These were a people to be feared, mistrusted, and ostracized, as they were clearly not capable of mingling with civilized English society. Author Edward Stillingfleet Cayley argued that the Irish were not "an Anglo-Saxon race” and therefore "English institutions" were not suited to the inferior Celtic species. ${ }^{71}$

The Anglo-Saxon was masculine, powerful, and Protestant. English boys were raised to be physically fit, and schools emphasized the masculine sports of swimming, riding, and shooting. ${ }^{72}$ The English education included "a fresh start in the training of the body" because it was argued that this was the only way to develop "many of the faculties of the mind."73 Victorian males came to believe that "prosperity comes to the homes where all the members are lively and active, and strong, fit to make their way in life.”74 Manly attributes, such as mental and physical health, vigor, cultural appreciation, family, moral excellence, hard work and religious convictions were not only encouraged, they were demanded. The Anglo-Saxon was the pinnacle of such a man. Thomas Carlyle posited that the modern Englishman was the epitome of culture with a sense of

\footnotetext{
${ }^{67}$ Smith, The Natural History of the Human Species, 435.

68 "Two Aspects of Ireland," Household Words conducted by Charles Dickens 4:80 (October, 1851): 28.

${ }^{69}$ Joseph Kenny Meadows, “The Irish Frankenstein,” Punch, November 4, 1843.

${ }^{70}$ P. Quin Keegan, “Irish Education: How Are We to Educate the Irish?” New Monthly, 121:724 (April, 1882): 349.

${ }^{71}$ Edward Stillingfleet Cayley, The European Revolutions of 1848, Volume III (London: Smith, Elder \& Co., 1856), 261.

72 “The English Boy of the Future,” Once A Week 7:164 (August, 1862), 204.

${ }^{73}$ Ibid, 203.

${ }^{74}$ Ibid, 205.
} 
spirituality and dedication to domestic and social duty like no other race on earth. ${ }^{75}$

Gentlemen manners were the "embodiment of unchangeable moral law” and the English male was one with a "readiness to brave hardship and suffering in a good cause.”76

Men such as explorer Richard Burton infused masculinity with this readiness for spirited adventurism and the colonial holdings became both a proving ground and a point of reference for the English male. In the colonial service, men could travel to exotic locales in order to tame the savage beast of both land and native. This savage native also served as an oppositional point of reference as the inferior of the species when set against the glory of the Anglo-Saxon. ${ }^{77}$ The popular press argued that forms of etiquette and social decorum "serve as a sort of freemasonry" and members of "good society... instantly know whether a stranger who happens to be presented to them is 'one of us' or not."78 Manliness thus provided a linguistic and conceptual framework for commending those to which the middle class gave its approval and disparaging to those they chose to exclude. Female traits, as well as their companionship, became unstimulating and hindered masculine improvement. ${ }^{79}$

In order to strengthen this internal image of Englishness, the popular press created an other to define themselves by what they were not. The Irish, as their closest neighbors and a seeming threat for centuries, became the natural target for this illusion of identity. In the twelfth century, Gerald of Wales described the Irish as barbarous murderers,

\footnotetext{
75 Thomas Carlyle, “Occasional Discourse on the Negro Question,” Fraser's Magazine (December 1849): 587.

76 “A Gentleman,” Illustrated Review: A Fortnightly Journal of Literature, Science and Art 1:3 (November, 1870): 99.

${ }^{77}$ John Tosh, Manliness and Masculinities in Nineteenth-Century Britain: Essays on Gender, Family and Empire (London: Pearson Longman, 2005), 7.

78 “Codes of Ceremonial,” London Society: An Illustrated Magazine of Light and Amusing Literature for the Hours of Relaxation 14:79 (July, 1868): 55.

79 Tosh, Manliness and Masculinities, 94, 92.
} 
thieves, and savages. His two works, The Topography of Ireland in 1187 and The Conquest of Ireland in 1189 established an image of the people of Ireland that continued for centuries. His works were still in publication in both Latin and English as late as the seventeenth century and his descriptive language was reinforced in later centuries in literature by such authors as Edmund Spencer, Sir Richard Musgrave, David Hume and Robert Carlyle. ${ }^{80}$ Gerald of Wales’ descriptions had, therefore, been resurrected as needed during troubling periods in the Anglo-Irish relationship and the popular media of the 1800s made use of them as well. By this time, the English had come to believe that their culture was "estranged from the Irish people” and centuries of conflict led to the image of the Irish savage straining at the borders of civilization, threatening to overrun civilized society. ${ }^{81}$ The Irish were white primitives, and the English focused their anger and frustration by defining them as a racialized population. Ireland was to be treated as an “enemy’s country,” wholly incompatible with the superiority of English civilization. ${ }^{82}$ This racial framework of 'savage' thus defined human differences and became deeply embedded in English thought and provided a foil against which they constructed their own identity as the pinnacle of civilized society. According to the popular press of the era, there was a considerable difference between the "character of the mass of Irishmen and that of the mass of Englishmen." ${ }^{83}$ What the English clearly were not was anything remotely identified as Celtic Catholic Irish.

\footnotetext{
${ }^{80}$ Kenny, Ireland and the British Empire, 6.

${ }^{81}$ English Historical Documents ed. W. D. Handock (New York: Oxford University Press, 1977), 311 and Smedley, "Race and the Construction of Human Identity," 694.

82 "Perraund on Ireland, Vol. I," Home and Foreign Review, 1 (October, 1862): 311.

${ }^{83}$ Goldwin Smith, Irish History and Irish Character (London: J.H. and Jas. Parker, 1862), 6.
} 


\section{Contradictions}

The process of creating the other was wrought with contradictions as the English continued to push the Irish farther from their concept of civilization and power. While defined as savage on one hand, they were also characterized as child-like, weak and feminine in nature, standing in stark contrast to the masculine superiority of the AngloSaxon. The English defined what was masculine in the Victorian male by what was feminine and child-like in the Irish male. According to Lord Rosse, for example, the Celt needed disarmed because that would be the equivalent of saying that a "child has a natural right to play with edged tools." ${ }^{84}$ Ethnologist Ernest Renan argued that the Celt was weak, troubled by an "inner world of dreams, illusions and fantasies essential to the feminine [character]" and like the delicate female, it was in the "very blood of the Celtic race to be peculiarly sensitive to verbal insult. ${ }^{85}$ Reverend Samuel Garratt contrasted the feminine "gracefulness of the Irish” to the "manliness of the English,” and Irish physical characteristics were labeled “effeminate." 86 The Celtic physique was one of “thinness and lightness," delicate in its construction. ${ }^{87}$ The London Quarterly Review argued that, when comparing the English and Irish, the English were clearly "the more masculine of the two” and the Irish more feminine, “even in their violence.”88 This feminine nature was the reverse image of the masculine Victorian man and thus the ultimate definition of the other within English society. ${ }^{89}$

\footnotetext{
${ }^{84}$ Lord Rosse, quoted in Senior, Journals, 31.

${ }^{85}$ Ernest Renan, quoted in Curtis, Anglo-Saxons and Celts, 40 and "Perraund on Ireland. Vol. I.," Home and Foreign Review 1 (October, 1862): 304.

${ }^{86}$ Rev. Samuel Garratt, "The Irish in London," in Motives for Mission: A Series of Six Lectures Delivered before the Church of England Young Men's Society, ed. Rev. Thomas Nolan, (London: Sampson, Low and Son, 1852), 217-218 and Massy, Analytical Ethnology, 12-19.

${ }^{87}$ Massy, Analytical Ethnology, 17.

88 “Art. III-1. The Irish People and The Irish Land,” London Quarterly Review 30:60 (July, 1868): 356.

${ }^{89}$ Tosh, 69.
} 
This dichotomy of gender was extended beyond the individual to encompass perspectives on nations, thus rendering the feminine nations impotent when compared to their masculine neighbors. During a tour of America, distinguished British aristocrat Lady Gregory heard a lecture on the nature of nations. In her diaries, she recounted the philosophical underpinnings of national character based on gender. The Celtic countries had a "soft, pleasing quality” much like a woman, with "no capacity for selfgovernment.” It was, according to Lady Gregory, the duty of the masculine nations, such as England, to "take the feminine nations in hand" and provide them with political structure. ${ }^{90}$ Women, and thus feminine nations, were to be "held by the strong hand" as they were “entirely passive.”" 91 And because women’s opinions did not matter because “they are never expected to talk sense,” it was understandable that these feminine nations were not in any position to counter the dominant masculine power. ${ }^{92}$ Renan argued that it was permissible to "assign sex to nations as to individuals" and it was "necessary to say without hesitation that the Celtic race... is an essentially feminine race."93 Ireland was, according to Victorian thinking, a passive vessel awaiting English control, and it stood in stark contrast to the masculine, self-possessed empire of Britain. It was this powerful intersection between the language of empire and that of manliness, according to historians Leonor Davidoff and Catherine Hall, that defined the struggle, duty, action, will, and character of powerful, dominate nations and added an additional facet to the

\footnotetext{
${ }^{90}$ Lady Gregory quoted in Curtis, Anglo-Saxons and Celts, 61.

${ }^{91}$ Maria G. Grey, “Men and Women,” Fortnightly Review, 29:174 (June, 1881): 778.

92 Mrs. Alfred Gatty, “The Old Folks from Home; or, A Holiday in Ireland in 1861,” Critic, 24:608 (March, 1862): 214.

${ }^{93}$ Ernest Renan, Oeuvres Completes II, 258 quoted in Malcolm Chapman The Gaelic Vision in Scottish Culture (London: Croom Helm, 1986), 85.
} 
Imperial social hierarchy that helped to reinforce the Irish as a colonized and thus inferior people. $^{94}$

\section{Catholicism as a mark of Inferiority}

A feminine nature was not the only weakness of the Irish nation. Just as the English defined themselves by their Protestant faith, they in turn defined the Irish other by its adherence to Catholicism as reflected in the continuing anti-Catholic rhetoric so prevalent in the 1850s. The popish faith was "illiberal" and "sinister" and the priests were seen as barriers to civilizing Ireland. ${ }^{95}$ Catholic leadership was wicked, greedy, cold, evil, implacable, sensuous, and the priests were more interested in worldly matters and scheming to advance themselves into positions of power than they were with spiritual matters. ${ }^{96}$ These same leaders in Ireland could not grasp the benefits that England brought to their land, and they "opposed ... to the utmost ... every improvement ... for they have no sympathy for comfort, or for cleanliness, or for prudence.”97 Their faith was a “matter of military drill,” and their spirituality was seeped in “carelessness;” so different from the reverence and dedication of the Protestant ministers of England. ${ }^{98}$ Filled with superstitions, the Irish clung to their faith and the English saw them as in habitants of an "incurably Catholic country" that was filled with “wild superstitions” and a "most primitive simplicity."99

\footnotetext{
${ }^{94}$ Leonor Davidoff and Catherine Hall, Family Fortunes, Revised Editions: Men and Women of the English Middle Class, Second Edition (London: Routledge, 2003), 193 and Paul Ward, Britishness Since 1870 (London: Routledge, 2004), 38.

95 “The Education Squabble in Ireland," London Review of Politics, Society, Literature, Art, and Science, 13:329 (October, 1866): 426.

${ }^{96}$ Lloyd's Weekly Miscellany, 2 (1850-1852): 1049; Lloyd's Entertaining Journal, 3 (July 7, 1845): 251; Family Herald, 1 (September 23, 1843): 317-318.

97 Senior, Journals, 83.

98 Carlyle, Reminiscences of My Irish Journey in 1849, 109.

${ }^{99}$ Goldwin Smith, Irish History and Irish Character, Second Edition (Oxford: J.H. and Jas Parker, 1862), 35 and "The Hopes of Ireland,” Rambler, Vol. II New Series Part VI (March, 1860): 282.
} 
Catholicism was such an anathema to English sensibilities that both the media and members of Parliament viciously attacked it well into the 1860s. After a series of riots on the docks, The Liverpool Mail argued that Catholicism had so "polluted [the] mental faculties” of the Irish dockworkers and that it had "debased [their] physical and moral habits” so far that was impossible to "ameliorate [their] condition as a social animal.” The Irish, according to the paper, didn't think like the English because they were “saturated with traditional falsehoods” from their priests. ${ }^{100}$ During debates on religious issues in Ireland, MP Horsman called the Catholic Church the "deadliest enemy to Protestantism that the most malignant enemy of Protestantism could devise.”101 The Catholic Church’s primary goal, according to MP Vance, was to create “a vast amount of mischief in the way of Papal aggression” that threatened English solidarity and prosperity. ${ }^{102}$ MP Horsman argued that "Popery has thriven” across Ireland, and like Vance, he believed that their mission "has been to engender crime and perpetuate ignorance.” This corrupted form of Christianity should be regarded as a "curse to the land it was meant to bless.” ${ }^{103}$ In a debate in the House of Lords, the Marquess of Westmeath declared that "there is an undying hatred” fuelled "by the Popish clergy towards England which nothing can extinguish.”104 Priests, according to Lord Dunsany, were disloyal to the Crown, and "had always been to keep the pot boiling” in encouraging violence and outrages toward England and its government. Their faith was little more than military

\footnotetext{
${ }^{100}$ The Liverpool Mail (July 19, 1851).

${ }^{101}$ MP Horsman, “Adjourned Debate,” House of Commons Debate, Vol. 190, (March 12, 1868): 1475.

${ }^{102}$ MP Vance, “Adjourned Debate,” 1509.

${ }^{103}$ MP Horsman, “Adjourned Debate," 1475 and Richard Tuthill Massy, Analytical Ethnology: The Mixed Tribes of Great Britain and Ireland Examined, and the Political, Physical and Metaphysical Blunderings on the Celt and Saxon Exposed (London: H. Bailliere, 1855), 156.

${ }^{104}$ Marquess of Westmeath, “(No. 18.) Second Reading,” House of Lords Debate, Vol. 190 (February 24, 1868): 1068.
} 
drill with no substance. ${ }^{105}$ Catholicism, historian James Anthony Froude argued, was "holding us back from better things," as it was inherently illiberal and sinister at its heart. ${ }^{106}$ Goldwin Smith argued that the entire institution was "an irregularity, an anomaly" and an "eye-sore to all ecclesiastics," particularly the Irish variety as it was "infected" by the wild native character of the people. ${ }^{107}$ The strength and power of the English middle class, the popular media argued, was its deeply ingrained anti-Catholic stance in opposition to the fanatical Irish. ${ }^{108}$

Under the Protestant banner came the ethics of self-government in a democracy, with freedom and liberty; all values that the Celt was incapable of either understanding or sustaining. Charles Hamilton Smith, in his work The Natural History of the Human Species, argued the Irish as a race were "deficient in sobriety of thought, and breadth of understanding," and were inherently unable to handle self-responsibility for their affairs. ${ }^{109}$ The Celt of France, according to historian Goldwin Smith, proved that although he was familiar with the concepts of political liberty, he "seems almost incapable of sustaining free institutions [and] reverts ... to despotism.”110 If the French could not adhere to the principles of liberty and democracy, then the Irish Celts were surely far too politically immature to ever successfully implement self-government and

\footnotetext{
${ }^{105}$ Lord Dunsany, “Observations. Motions for a Paper,” House of Lords Debate, 26 February 1866 Vol. 181 and Thomas Carlyle, Reminiscences of my Irish Journey in 1849, (New York: Harper and Brothers, 1882), 109.

106 James Anthony Froude, “The Philosophy of Catholicism,” Short Studies on Great Subjects, Third Edition (London: Longmans, Green and Co., 1868), 124 and "The Education Squabble in Ireland," London Review of Politics, Society, Literature, Art and Science 13:329 (October, 1866): 426.

${ }^{107}$ Smith, Irish History and Irish Character, 30, 35.

108 "Perround on Ireland. Vol. I," Home and Foreign Review 1 (October, 1862): 76; For secondary analysis of the anti-Catholic stance in England see: E.R. Norman, Anti-Catholicism in Victorian England (1968); D.G. Paz, Popular Anti-Catholicism in Mid-Victorian England (Stanford, California, 1992), D.G. Paz, "Anti-Catholicism, Anti-Irish stereotyping and anti-Celtic racism in mid-Victorian working-class periodicals,” Albion, Winter (1986).

${ }^{109}$ Smith, The Natural History of the Human Species, 433.

${ }^{110}$ Ibid, 18.
} 
self-control. ${ }^{111}$ Incapable of understanding the constitutionalism inherent in the English sensibility, they clung to their limited views of tyrannical clan leadership and were, therefore, "easily governed” by stronger forces. They displayed a lack of independence and no sense of law or liberty. ${ }^{112}$ The Irish were simply too primitive, locked into the despotic world of their faith and limited minds, to ever achieve political sentience. The Irish character, in contrast to the Anglo-Saxon, was so degenerate that it "renders her inferior to freedom" and the people of Ireland "were not and never would be ready to handle... basic English liberties."

\section{The Primitive Savage}

The violent nature of the Irish other was translated into another very real threat, the criminal. As early as 1849, criminal activity in Ireland was considered of a "character most hideous" with "murders the most savage” being committed on a regular basis. ${ }^{114}$ The Irish were seen as lawless, violent criminals pouring into English cities like the plagues of yesteryear. ${ }^{115}$ The Manchester Guardian described the "almost murderous spirit of violence that exists in the breast of some of the lower order of Irish" that drove crime rates up across the city. ${ }^{116}$ The Manchester Courier regularly reported incidences of violence in 'Irish Town,' such as the March riot in 1851. The report described the "entire neighborhood" apparently involved in the street brawl "fighting with pokers,

\footnotetext{
${ }^{111}$ Curtis, Anglo-Saxons and Celts, 12. Curtis argues that of all the Celtic races across Europe, the Irish were considered the most Celtic with the purest Celtic bloodlines, and therefore the lowest of all the Celts, 22.

${ }^{112}$ Goldwin Smith, Irish History and Irish Character (London: J.H. and Jas Parker, 1868), 18 and Knox, 57.

${ }^{113}$ Thomas Davis, “Letter,” The Nation, July 13, 1844: 173 and Lord John Manners, Notes of an Irish Tour (London: J. Ollivier, 1849), 51.

${ }^{114}$ George Lewis Smith, Ireland: Historical and Statistical (London: Whittaker \& Co., 1849), 54.

115 "Rev. Hayman and Irish Crime,” The Times, December 10, 1879: 12.

${ }^{116}$ Manchester Guardian, January 2, 1850: 3.
} 
sticks and axes, like incarnate fiends." ${ }^{117}$ A deputy constable in Manchester reported that "if a legal execution of any kind is to be made" in the Little Ireland district, or Angel Meadow, then the officer who "serves the process almost always appears to me for assistance to protect him” because of the abuse heaped upon the serving officer. A night watch superintendent added that in order to apprehend one Irishman in the Irish parts of town, it took "ten or twenty, or even more, watchmen.” He pointed out that the entire neighborhood "will turn out with weapons, even women, half-naked, carrying brickbats and stones for the men to throw." ${ }^{, 18}$ In 1868, Charles Dilke’s warning echoed those of previous generations when they pointed out that "a fierce and easily-roused people will throng the cities, while the law-abiding Saxons... will cease to rule it."119

By the mid-1860s, with 11,000 Irish immigrants in English prisons and "no doubt many of the remainder born of Irish parents," the fear of criminality seemed very real. Although the Irish represented less than one-fifth of the total population in London, for example, it was reported that they committed more than one-third of the criminal acts across the city. ${ }^{120}$ Barrister at law, Luke Owen Pike compared crime rates in the north of England with those of the south-west as well as with a comparison of the immigration rate. He found that 3224 people per every 10,000 were immigrants in the north-western regions that included Liverpool and Manchester. In this region, 115 persons were annually committed to prison per every 10,000. In the south-west, a region that included Cornwall and Devonshire, there were 1,103 immigrants for every 10,000 persons. Only 30 people per 10,000 were committed to prison in this region. According to his figures,

\footnotetext{
${ }^{117}$ Manchester Courier, March 29, 1851: 9.

${ }^{118}$ Report of the Constabulary Commission, 169, (1839): 87-88.

${ }^{119}$ Charles Wentworth Dilke, Greater Britain: A Record of Travel in English-Speaking Countries, 1866 and 1867 Volume I (London: MacMillan and Co., 1868), 44.

120 “Judicial Statistics,” Capital and Labour, 44, December 23, 1874: 1017.
} 
crime in the north-west was four times that of the south-western regions. He drew a straight line between the two set of statistics and argued that in areas with the "most immigration there is [the] most crime.” He believed that the Irish immigrant, 6.6 percent of the total population in the north-western counties, had a "stronger tendency than the native population to break the existing laws," as they represented 25.6 percent of the prison population. ${ }^{121}$ Social researcher and reform advocate, Henry Mayhew, in his work The Criminal Prisons of London and Scenes of Prison Life, indicated that 33 percent of all arrests for assault on police in Liverpool and Manchester between 1841 and 1871 were Irish. He referred to them as common thieves characterized by "mental imbecility and low cunning.”122 Edward Rushton, the stipendiary magistrate for Liverpool reported a 21 percent increase in the number of people brought before the borough magistrates from 1846 to 1848 . In 1846 , the total figures were 18,171 while in 1848 the figures rose to 22,036. Convicted felons increased by 98 percent from 3,889 in 1845 to 7714 in 1848 . In 1848, the total number of Irish males convicted of criminal activity was 37 percent and the total number of females was 46 percent while the total number of Irish in the entire population was only 23 percent. ${ }^{123}$ By 1861, 25 percent of the Lancashire region's prisoners were Irish-born. ${ }^{124}$ The Irish, according to Dilke, were “dangerous inhabitants

\footnotetext{
${ }^{121}$ Luke Owen Pike, History of Crime in England Illustrating the Changes of the Laws in the Progress of Civilisation: Written from the Public Records and other Contemporary Evidence Volume II (London: Smith, Elder and Co., 1876), 516-518.

${ }^{122}$ Henry Mayhew and J. Binney, The Criminal Prisons of London and Scenes of Prison Life (London: Cass, 1862), 111, 134.

${ }^{123}$ Edward Rushton cited in Frank Neal, "A Criminal Profile: The Liverpool Irish,” Transactions of the Historic Society of Lancashire and Chesire, Volume 140 (1991): 178.

${ }^{124}$ David Fitzpatrick, “A Peculiar Tramping People: The Irish in Britain 1801-70,” A New History of Ireland, ed. W.E. Vaughan, (London: Claredon Press, 1989), 628.
} 
for mighty cities,” bringing crime and degradation to the good citizens of England as this particular segment of the lower class became equated with the dangerous class. ${ }^{125}$

\section{The Fenian Brotherhood: Proof of the Violent Savage}

The image of the violent criminal was firmly solidified by the growing perception of Fenian activity in Ireland. The Fenian Brotherhood was an Irish republican organization founded in the United States in 1858 by John O’Mahony and Michael Doheny. It was a precursor to Clan na Gael, a sister organization to the Irish Republican Brotherhood. Members were commonly known as 'Fenians.' O’Mahony, who was a Celtic scholar, named his organization after the Fianna, the legendary band of Irish warriors led by Fionn mac Cumhaill. The Fenian Brotherhood traced it roots back to the United Irishmen and the Rebellion of 1798 against English control over Ireland. They also followed in the footsteps of the Young Ireland Movement, the youthful Irishmen who became frustrated with O’Connell's lack of progress in getting the Act of Union repealed. Through newspapers and propaganda, they set out to create a spirit of pride and an identity based on nationality rather than on social status or religion and it was this tradition that the Fenians sought to uphold. After numerous raids throughout Canada in order to raise funds, a raid was planned and executed for the liberation of Ireland. In 1866, The Fenian Rising, comprised of native Irish and Irish-Americans who landed in Cork, proved to be a disaster. It was poorly organized and had minimal public support.

The Times reported that those "persons who considered themselves subjects of the United

\footnotetext{
${ }^{125}$ Dilke, 45; For secondary analysis of the Irish criminal see: Roger Swift, "Crime and the Irish in nineteenth-century Britain” in eds. Swift \& Gilley Irish in Britain; Swift, "Heroes or villains? The Irish, crime and disorder in Victorian Britain" Albion, 29, 3 (1997). For local histories on this issue see: P. Mulkern "Irish immigrants and public disorder in Coventry, 1845-1975," Midland History, 21 (1996); M. McManus, "Folk devils and moral panics? Irish stereotyping in mid-Victorian Durham," Bulletin of the Durham County Local History Society, 53 (December, 1994); S.J. Davies, "Class and police in Manchester, 1829-80" in City, Class and Culture: Studies of the Social Policy and Cultural Production in Victorian Manchester eds. A.J. Kidd and K.W. Roberts (Manchester, 1985).
} 
States" arrived in Ireland and "regardless of all humanity... and without any respect to law and order” incited the local populous to violence against the Crown. Their sole purpose, the article posited was "open rebellion [for] a separation between the two different parts of Her Majesty’s dominion. ${ }^{126}$ Most of the Irish-American officers expected to be commanding an army against England, were instead imprisoned and sporadic disturbances around the country were easily suppressed by the police, army and local militias. This uprising only succeeded in solidifying the belief that the Irish had "for years been running almost indiscriminately against the law" and were becoming a social menace in both Ireland and England. ${ }^{127}$ The Times put its weight behind the growing support for "special legislation" to quell the "special outrages" and "dastardly crimes recently committed by persons calling themselves Fenians." ${ }^{128}$

In 1867, an office of the Irish faction, the Irish Republican Brotherhood, opened in Manchester, and openly opposed the older factions of the organization both in Ireland and America. All three organizations continued to exist throughout the later decades of the 1800 s as Home Rule became an issue. ${ }^{129}$ A critical component of all three factions was, however, the ease with which their members resorted to violence when necessary to achieve their goals. ${ }^{130}$

Although the violence was, for the most part, confined to Irish shores, there was an increasing fear that these ruffians and hooligans were going to bring their savageness

\footnotetext{
126 The Times, January 1, 1868; For a general history on the Fenian Movement see: R.V. Comerford, The Fenians in Context: Irish Politics and Society 1848-1882 (Dublin: Wolfhound Press, 1985).

127 The Times, January 30, 1866.

128 The Times, January 1, 1868.

${ }^{129}$ Owen McGee, The IRB: The Irish Republican Brotherhood from The Land League to Sinn Féin (Dublin: Four Courts Press, 2005).

${ }^{130}$ For a secondary analysis of the English faction of the Fenian movement see: P. Quinlivan and P. Rose, The Fenians in England, 1865-1872: a Sense of Insecurity (London: J. Calder, 1982); John Newsinger, Fenianism in mid-Victorian Britain (London: Pluto Press, 1994)
} 
to English shores. Shortly after the IRB opened their office in Manchester, there was a much publicized incident with the local police. According to The Times, the police were transporting Fenian prisoners and the van was attacked. Thirty or forty Irishmen assaulted the van, released the prisoners, and opened fire on the officers. Several policemen were shot and one innocent bystander was killed in the melee. ${ }^{131}$ In contrast to the outrage of the English news sources, poet T.D. Sullivan made martyrs of those involved in the raid with his poem The Smashing of the Van written in 1867 in which he describes the gallantry and heroism of the Irish fighting for the freedom of their compatriots. Fenianism was not simply a rebellion, but an "uprising of the Celt against the Saxon" and was part of an Irish "anti-Saxon crusade." ${ }^{132}$ This homegrown fear was intensified when only months after the prisoner breakout, Sergeant Francis Maguire of the $72^{\text {nd }}$ Highlanders, a regiment stationed in Manchester, was arrested and court martialed for promoting Fenianism within the ranks of his unit. He had apparently been communicating with members of local Fenian groups for some time prior to his arrest and he had been spotted in a Fenian funeral procession. Lower ranking soldiers reported his seditious talk and according to The Times, reported his activities to his commanding officer. During the investigation, it was discovered that he had given ammunition to several Fenians as well as received them as visitors in his barracks on several occasion. ${ }^{133}$ Although the article never directly mentioned the prisoner breakout, the story was still fresh in the mind of the public and the references to ammunition made the Fenian connection even more dangerous as the "dire disease” infiltrated even the military. ${ }^{134}$

\footnotetext{
${ }^{131}$ The Times, September 19, 1867.

132 The Times, September 25, 1865.

${ }^{133}$ The Times, December 24, 1867.

${ }^{134}$ Ibid.
} 
Another of the major events that sealed the fate of the Fenian image was the failed attempt to take Chester Castle. John Devoy, one of the militia, firmly stressed that the action was “only a demonstration,” loosely planned with very few weapons of any threat. ${ }^{135}$ In an interview with The Illustrated Times, Chief Constable for Chester G.L. Fenwick argued that the hard working people of Chester had donated countless funds over the years in theory to support to poor of Ireland, but in reality, the money was fuelling the "conspiracy” of "men of smart military bearing” and their sizable collection of arms, a very different point of view from that of the rebels involved. ${ }^{136}$ The suspension of the Habeas Corpus Act was not, according to MP Gathorne Hardy, "a coercive but a protective Act.” He argued that it was “coercive against brigands; but it is protective for honest men,” and necessary in light of the disturbances across the island. ${ }^{137}$

The Fenians were a "novel form of war” against England "by an enemy wholly unlike any former foe” ever encountered on the battlefield. ${ }^{138}$ This was not the enemy of distant shores in lands to be conquered by the might of the British Navy. These were citizens of the empire against the Crown; criminals who did not hesitate to "blow up a row of houses inhabited by people who had never injured them in any way,” and the public was outraged. ${ }^{139}$ This was, according to The Times, a kind of "chronic treason" that "stalks in the dark, springs mines under our feet, menaces and attacks our dockyard, our arsenals, and other public establishments.”140 This was, in essence, guerrilla style terrorism. The news media reported plots of arson, assassination, murder and robbery

\footnotetext{
135 John Devoy, Recollections of an Irish Rebel 1929, (New York: Chas. D. Young, 1929), 187-189.

${ }^{136}$ The Illustrated Times, February 16, 1867.

${ }^{137}$ Gathrone Hardy, “Adjourned Debate,” House of Commons Debate, Vol 190 (March 12, 1868): 1475.

138 "England and Her Fenian Enemy," The Dublin University Magazine: A Literary and Political Journal, Volume LXXI (January-June, 1868), 115.

${ }^{139}$ Ibid, 119.

${ }^{140}$ The Times, September 25, 1865.
} 
under the banner of Fenianism with, according to the media, "assurances of unlimited support from America." ${ }^{\not 41}$ English anger was directed at the United States because England believed many of the Irish immigrants were supporting the rebellion, particularly after so many Americans had been arrested in the aborted invasion of Ireland. The conspiracy was, The Times argued, "hatched and organized... among a section of the population who were Irish by nature and Americans by habit." ${ }^{142}$ America was a hotbed of conspiracy supporting the Fenian menace with the sole purpose of "humiliating and torturing England." ${ }^{, 43}$ Secret societies flourished in the United States, allowing Fenianism to take root and prosper. ${ }^{144}$ The Times even accused the American Congress of harboring "Fenian belligerents" bent on ravaging Ireland with "fire and sword." 145 England was being forced into "repelling a mortal attack" from this band of murdering nationalists and vile criminals. ${ }^{146}$

\section{The Drunk}

The two images of the Irish other, that of the violent criminal and the immoral degenerate, were united as alcoholism became synonymous with the Irish in English society. By the 1860s, Victorian society viewed moderation and self-control as essential facets of the proper gentleman and drunkenness was regarded as a "disgrace, not a thing to glory in." ${ }^{147}$ Drunk and disorderly conduct was considered a social menace and labeled a criminal offense. The Irishman loved his glass of whisky and alcohol became closely

\footnotetext{
141 "England and Her Fenian Enemy,” The Dublin University Magazine, 115; The Times September 25, 1865.

${ }^{142}$ The Times, January 30, 1866.

143 "England and Her Fenian Enemy," The Dublin University Magazine: A Literary and Political Journal, Volume LXXI (January-June, 1868), 116.

${ }^{144}$ The Times, January 30, 1866.

${ }^{145}$ The Times, March 20, 1866.

146 "England and Her Fenian Enemy," The Dublin University Magazine: A Literary and Political Journal, Volume LXXI (January-June, 1868), 120; The Times, January 30, 1866.

147 "Perround on Ireland. Vol I.," Home and Foreign Review, 1 (October 1862): 296.
} 
associated with Irish communities over the decades. ${ }^{148}$ As early as the 1840s, the English were warned against giving alms to Irish beggars because the pennies collected were merely to "supply his wants or minister to his appetites" for spirits. ${ }^{149}$ The city of Liverpool, famous for its masses of Irish, arrested an average of 17,000 persons a year for the offense. ${ }^{150}$ From 1845 through 1854, the city of Manchester arrested 1552 Irish for being ‘drunk and incapable,' and 2425 Irish being ‘drunk and creating a breach of the peace. ${ }^{151}$ The Irishman was "a creature of impulse" unable to resist the "satanic attractions of firewater." 152

\section{The Irish Other in Literature}

Even the literature of the times began to reflect this growing fear of the invasion of the immigrant. Like the fictitious portrayals of the violent Irish Chartist agitators, Emily Brönte’s novel Wuthering Heights features an outsider, an intruder invading the genteel English landscape and wreaking havoc through his presence. Literary scholar Terry Eagleton argues that Heathcliff, the dirty, ragged black-haired child who arrived speaking gibberish, represented the classic image of the Irish famine vagrant. He is described in the novel as a savage beast and a lunatic demon; both common descriptions of the Irish during this period. Although he tries to conform to English customs, rules, and manners, he never completely succeeds because he doesn't belong. His actions

\footnotetext{
${ }^{148}$ Smith, Irish History and Irish Character, 13.

${ }^{149}$ Great Britain, Seventh Annual Report of the Poor Law Commissioners with Appendices, (London: William Clowes and Sons, 1841), 48.

${ }^{150}$ Luke Owen Pike, History of Crime in England Illustrating the Changes of the Laws in the Progress of Civilisation: Written from the Public Records and other Contemporary Evidence Volume II (London: Smith, Elder and Co., 1876), 431.

${ }^{151}$ Mervyn Busteed, “The Irish in Nineteenth Century Manchester,” Irish Studies Review, 18 (Spring, 1997): 12.

${ }^{152}$ Ellis, Irish Ethnology, 64 and James Phillips Kay Shuttleworth, The Moral and Physical Condition of the Working Classes Employed in the Cotton Manufacture in Manchester (London: Frank Cass and Co. Ltd, Second Edition, 1970), 151.
} 
throughout the novel pose a threat to English society as he becomes a colonizer with the takeover of the Heights. Crawling from the urban slum, he usurps the landed English establishment in the countryside. This invasion threatens to redefine the very notion of Englishness among the landed gentry as Heathcliff introduces foreign ways into the community. He is a despot, ruling his estate with an iron fist and eventually falling into ruin. Brönte’s novel, Eagleton argues, represented a clear lesson to the English population that the 'other' brought chaos and destruction to England. Where the Chartist violence failed, Heathcliff succeeds because he has snuck in through the back door. In the end however, like the Chartists, he proved incapable of assimilating into civilized society and unable to govern as a proper Englishman. The lesson of the novel for Victorian England was simple - society must continue to marginalize the Irish to prevent such tragedies from becoming reality. England must be kept free from such contamination. ${ }^{153}$

\section{The Irish Other in Society}

This lesson was reinforced by the scientific rational of the time concerning the large numbers of Irish offspring and their potential threat to social order. Historian and journalist Goldwin Smith pointed out that "this miserable race of serfs multiplied in their recklessness and despair,” thus overpopulating their own county and they were repeating the pattern in the Irish ghettos of England. ${ }^{154}$ The Irish bred in record numbers and, according to the science of the day, the child "like the young of inferior animals, begins life with a tendency to act after the manner of its kindred." ${ }^{155}$ The instinct for either positive or negative behavior "descend from parent to offspring, generation after

\footnotetext{
${ }^{153}$ Terry Eagleton, Heathcliff and the Great Hunger (London: Verso, 1995).

${ }^{154}$ Smith, Irish History and Irish Character, 148.

${ }^{155}$ Pike, History of Crime, 496.
} 
generation" and "like beings act in like manner." ${ }^{156}$ Because these hereditary traits were "common to all or nearly all of the members of any animal group," the children of these savage, immoral creatures were destined to continue the Irish plague set upon the English public as science argued that "few or none diverge" from these patterns. ${ }^{157}$

The very real problems the Irish immigrants brought to England continued long past the end of the famine years, and these issues only served to reinforce the complex and increasingly negative views of the English public. In 1861, six years after the last of the blight devastated Ireland, there were 890,423 paupers on the rolls of England and Wales with a total cost to the taxpayers of £5,778,943. In 1866, a full decade after the famine, the pauper rolls stood at 958,824 persons with a total cost of $£ 6,959,840$. While these figures included both the Irish and English poor, that mattered little to the public. It was the perception of the Irish as degenerate paupers that had solidified in the public's mind over the decades and these figures served as solid evidence they were still draining the financial resources of hardworking Englishmen. Expenses in Ireland did nothing to dispel this image. In 1861, there were 50,683 paupers registered with a total cost of $£ 516,769$ and in 1866, like England those numbers increased. The total paupers registered that year were 68,650 with a total cost of $£ 676,776 .{ }^{158}$ With every decade that passed, the same "living skeletons" sucked the life out of the English in every possible capacity. ${ }^{159}$

By 1868, the attitudes in England reflected the anger, frustration and irritation toward the financial drain. In a Parliamentary committee, the MP for Haddingtonshire,

\footnotetext{
${ }^{156}$ Ibid, 505.

${ }^{157}$ Ibid, 506.

${ }^{158}$ Thom's Statistics of Great Britain and Ireland (Dublin: Alexander Thom and Sons, 1868), 6.

${ }^{159}$ MP Lanigan, "English Poor Law.-Removal of Irish Paupers.-Question.," House of Commons Debate, Vol 157 (March 16, 1860): 738.
} 
Lord Elcho, declared that "public money spent in Scotland is not one-half or one-fourth of what is spent in Ireland," and he argued that these expenses were nothing more than to "pacify Ireland" every time her people rose in turmoil. ${ }^{160}$ The Illustrated London News argued that the Irish carried "a feeling of bitter hatred" toward England yet the English "spend ten millions of money" in aid for the country "with as little real benefit as if the sum had been sunk into the sea." ${ }^{161}$ MP Horsman argued before Parliament that the "patriotism of the Irish is not the patriotism of the same classes in England and Scotland." He stressed that patriotism to the English meant love of country, and loyalty to the Government and the Crown. Irish patriotism, however "means love of Ireland and not love of England; it means too often love of Ireland and hatred of England and of its Government.” Ireland therefore, instead of being a source of strength and security to England in times of danger, was often "a source of weakness, and gloated over by our enemies as a vulnerable point." 162

These paupers continued to live in the disease-riddled, filthy conditions like those that came before them, and by the 1860s, there was no hope of ever changing the Irish patterns. In 1868, Goldwin Smith described the Irish of Manchester as "living in extreme indigence, and without the least attention to cleanliness" in the "worst quarters of the town" and these neighborhoods, just as Dr. Shuttleworth noted in the 1830s, were the source of the "great bulk of our fever patients." 163 The tide of misery that had "filled Ireland to the brim" had "overflowed into England," and according to Smith brought wave after wave of "pauperism and disease," thus compelling England to "pay attention

\footnotetext{
${ }^{160}$ Lord Elcho, “Committee,” House of Commons Debate, Vol 191 (April 30, 1868): 1643.

161 The Illustrated London News April 3, 1852.

162 MP Horsman, “Adjourned Debate,” House of Commons Debate, Vol 190 (March 12, 1868): 1475.

${ }^{163}$ Smith, Irish History and Irish Character, 314.
} 
to... the Irish people." ${ }^{164}$ London was no better than the north. Macmillan's Magazine brought its readers stories of a family with a dozen children "so verminous" that they had been forced into the cellar rooms by their landlord at the request of other tenants. By the 1860s, the popular press made no attempt to hide the "dislike and contempt" for the Irish with their endless sea of issues, problems, and degradation. ${ }^{165}$ According to the English, the Irish were simply not worthy of the freedom they sought so earnestly. ${ }^{166}$

\section{Nothing Ever Changes}

From the English perspective, nothing ever made a difference in Ireland or with the Irish people or their offspring. In an 1867 inquiry in Parliament on the state of Ireland, Chief Secretary for Ireland Lord Naas described the "considerable distress” from the famine-stricken regions in the west of Ireland. He noted that the local people were being forced to choose between feeding themselves or their cattle, and as a consequence, large numbers of cattle were left to starve. ${ }^{167}$ Stories of starvation, deprivation and death had saturated the popular press for over five decades and no amount of tax-payer relief, charity, or loans had ever made a difference. In an 1865 Parliamentary debate, Sheffield MP Roebuck argued that there was no reason for the continued problems in Ireland other than the Irish themselves. After Catholic Emancipation, the English government "has been endeavouring with all its earnestness and all its power to do justice to that country... as far as law is concerned then Ireland is well governed." It is the people who "indulge in this constant whining," with a litany of complaints against England and a resolute

\footnotetext{
${ }^{164}$ Ibid, 151.

165 “Anecdotes About the London Poor,” Macmillan's Magazine, 20:119 (September 1869): 400; “The Hopes of Ireland,” Rambler Volume II New Series Part VI (March 1860): 284.

${ }^{166}$ Edward Stillingfleet Cayley, The European Revolutions of 1848, Volume III (London: Smith, Elder \& Co., 1856), 242.

${ }^{167}$ Great Britain, “Question,” House of Commons Debate, Vol 187 (May 1867): 940.
} 
antipathy for self-improvement and the "misery of Ireland," according to Roebuck came clearly "from her own children." ${ }^{\text {"In }}$ In 1864, the Irish potato crop was 3,400,000 tons, and the total value of the cereal and potato crop for that year was $£ 20,000,000 .{ }^{169}$ In spite of the successful harvests in the post-famine decades, the misery across the island continued and the immigrants continued to enter England in an endless stream of poverty. During an 1868 Parliamentary debate, MP Vance argued that the Irish had a long-standing history of diverting blame for "Irish distress" from "its true source," the people themselves. Over the decades, he pointed out in his speech, they first blamed the Act of Union, then the Corn Laws, then the Incumbered Estates Act, without ever once addressing the local population's contributions to the crises. ${ }^{170}$ After £10,000,000 in government relief during the famine years, nothing had essentially changed. ${ }^{171}$ The Irish story seemed a never-ending narrative of suffering that they then heaped upon the hardworking people of England as they flooded English shores.

After years of conflict, poverty, and immigration, the Irish had become something detestable; something to be loathed and reviled, because the Irish never became less Irish and more English. ${ }^{172}$ According to Scottish surgeon, author, and racial theorist Robert Knox, the Celt was as "distinct from the Saxon as he was seven hundred years ago" and, as the "source of all evil," the entire race "must be forced from the soil ... England's safety depends on it." ${ }^{173}$ After a brief tour of Ireland, Queen Victoria argued that "these

\footnotetext{
${ }^{168}$ MP Roebuck, “Adjourned Debate Continued,” House of Common Debate, Vol 177 (February 27, 1865): 750 .

${ }^{169}$ Great Britain, “Adjourned Debate Resumed,” House of Commons Debate, Vol 177 (February 27, 1865): 816.

${ }^{170}$ MP Vance, “Adjourned Debate,” House of Commons Debate, Vol 190 (March 12, 1868): 1509.

${ }^{171}$ John Stuart Mills, “Adjourned Debate,” House of Commons Debate, 12 March 1868 Vol. 190: 1521.

${ }^{172}$ Historian Kevin Kenny argued that England's solution to the 'Irish problem' was that Ireland needed to become less Irish and more British, 3.

${ }^{173}$ Knox, The Races of Men, 69, 57, 379.
} 
Irish are really shocking, abominable people - not like any other civilized nation." ${ }^{\text {"174 }}$ Neither the government nor the people of Britain could reconcile themselves to the Irish nation. They were a race characterized by "pugnacity, licentiousness, [and a] lack of moral courage," leading Thomas Carlyle to ask, "What can you make of the wretched Irishman?” 175 Everywhere these people went, they brought moral decay, "spreading misery ... disaffection [and] endangering the pubic tranquility.” The Irish were “incurably idle, improvident, disorderly, and vicious, ever tempted to avenge upon his betters the misery which is his own fault." ${ }^{176}$ They were destroying the "security of property" and were seen as a threat to British social institutions, and thus undermined the very "safety and integrity of [the] empire."

In his 1710 work on the principles of human knowledge, Irish philosopher George Berkeley argued that people cannot truly know the world of objects, human beings instead know only their mental ideas of objects, and the external world thus rests on a collection of subjective ideas. ${ }^{178}$ The English, with their "long history of enmity with... the Irish” had generated a subjective, largely negative image of the Irish that, by the 1860s, had become institutionalized as a significant facet of the public consciousness in defining the Irish as the 'other.' The popular press, theorist Michel Foucault argues, created a body of knowledge and interpreted it for the middle class. That interpretation allowed Victorian society to exclude and isolate this immigrant community and create a

\footnotetext{
${ }^{174}$ Queen Victoria quoted in England and Ireland Since 1800, Patrick O’ Farrell (London: Oxford University Press, 1975), 49.

${ }^{175}$ Ellis, Irish Ethnology, 27-40 and Thomas Carlyle, The Works of Thomas Carlyle: 30 Volumes, Vol. XXIX (London: 1898), 137.

176 “Art. III.-1. The Irish People and the Irish Land,” London Quarterly Review 30:60 (July, 1868): 354.

${ }^{177}$ George Poulett Scrope, How To Make Ireland Self-Supporting; or, Irish Clearances, and Improvements of Waste Lands (London: James Ridgeway, 1848), 30.

${ }^{178}$ George Berkeley, A Treatise Concerning the Principles of Human Knowledge, translated annotations by Charles P. Krauth (Philadelphia: J.B. Lippincott, 1881), 27.
} 
negative stereotype that would only intensify throughout the later portion of the century as issues such as Home Rule and increased Irish violence threatened the security, stability and status quo of the Empire. ${ }^{179}$

${ }^{179}$ Smedley, 694. 


\section{Conclusion}

The change in attitudes that marked the period from 1820 through 1870 was not, it should be emphasized, unprecedented. English perceptions of the Irish have for centuries followed a pattern alternating between the pessimistic and the optimistic. Periods of several decades in which most English observers looked ahead to increasing cooperation and integration between the two countries were usually punctuated by shorter periods in which social or military crises in Ireland, such as those of 1641 and 1798, stirred feelings of bitterness and contempt. English hostility, while it lasted, involved the adoption of punitive, and the abandonment of reformist legislation, but generally softened in one or two decades unless another crisis occurred to renew it.

The fact that a change in public perceptions of Ireland took place between 1820 and 1870 does, however, run counter to the still commonly-accepted view that English perceptions of the Irish were uniformly hostile and even racist throughout the course of recorded history. More interesting and relevant is the degree to which the English view of the Irish was predicated upon, and shifted in connection with, English preoccupations in the areas of economic and moral philosophy, science, and politics. Popular views of religion, the economy, science, gender and class relations, imperial stability and defense, and imperial growth all had their impact on English attitudes toward the Irish.

The cautious optimism that generally marked the period before the famine, as outlined in Chapter One, was heavily influenced by the emerging doctrines of moral and economic liberalism. Attitudes toward Ireland in these years were partly defined in terms of recent theories about human nature and origins, and natural law both moral and economic. At the same time, Irish pressure for repeal of the Act of Union forced the 
English to define their own attitudes in reaction, by stressing the union as natural, and justifying it by both history and the future. Irish history showed what the country would descend to without enlightened, liberal English rule. Hope for Ireland's future rested wholly upon the unfettered exercise of English rule. The idea of the British family of nations, and more particularly of the English-Irish union as a paternal one, was advanced to demonstrate the impossibility of a separation.

Irish activity within England, however, began to have a considerable impact on the paternal perspectives toward the Celts. During the 1830s and 1840s, the rise of the radical working class movements began to shape socio-political discourse. The middle class, wary at best and frightened at worst, by these movements, developed an increasing negative attitude toward the associations and groups pushing for reform. The Chartists, as the most prominent, became a primary target. With a strong base in the northern industrial centers of England under the leadership of Irishman Feargus O'Conner, the Irish immigrant became intrinsically linked with the violent, negative image of the radical reformer. These attitudes, as examined in Chapter Two, were the beginning of an everincreasing rift between the Irish and the rest of English society.

Chapter Three examines the Great Famine and how events in Ireland continued to shape public perceptions in England. The starvation and devastation created a seemingly endless pit of charity, and the English simply grew tired of supporting their neighbors. Had charity weariness been the only issue, perhaps the frustration would have been limited and thus faded as the famine came to a close. But the ever-increasing violence, and the perceived threat to the English social order, was just too much for the middle 
class to bear. Their money and sympathy was directed at a people who hated them and wished nothing more than to commit violent treason against the Crown.

This growing frustration was fueled by the increasing numbers of Irish that flocked to English shores in the wake of the famine. Chapter Four explores the 1850s and the Irish population within England. They were paupers, Catholic and savage in the minds of the English middle class. Prominent writers such as Thomas Carlyle referred to them as a plague, a disease that was infecting the whole of England and they became an other within the social structure. As their numbers increased, this infection threatened to bring Popery back to the civilized shores of Protestant England. These people also brought a very real infection as they spread diseases such as typhus and cholera. By the 1850s, any paternal benevolence had succumbed to both the imagined and the real issues threatening the English social order.

Chapter Five explores the development of this anger aimed at the disease riddled Catholic pauper that intensified with the intellectual and social acceptance of scientific racism in the later part of the century. Throughout the 1850s, new ideologies and theories emerged among the intelligentsia, and by the 1860s, this science had filtered down to the middle classes through the popular press. Darwin's classifications and evolutionary theories gave rise to the argument that humans could also be sorted into hierarchies. Characteristics were intrinsic to races, immutable in the biological makeup. Savages remained such, and were incapable of evolving. The Irish other, with his primitive faith, violent nature, and limited intellectual capacity, was one of the savage races. Incapable of governing his own actions or his own country, he needed dominated and subdued by the imperial might of England on both an individual and national level. This ideology also 
gave the middle class the necessary rhetoric to justify Irish exclusion from the welfare state en masse. They were biologically predisposed to poverty and degradation and English charity was, therefore, useless. Why fund a people who will never improve?

The period from the 1820s through the 1860s presented the English with a rapidly

changing set of social, political and economic circumstances in both England and Ireland. Chartism fermented socio-political tension throughout England and threatened the stability of middle class comfort until it fell from favor in the late 1840s. In Ireland, the central event was of course the famine, which exposed the fallacy of liberal government and, in appearing to reverse the march of Irish moral and material progress, belied the Whig notion of Irish history as a steady progression toward prosperity and civilization under English tutelage. The social and economic dislocation consequent upon the famine, in combination with the 1848 Young Ireland rising and the Chartist Movement, added urgency to fears developing in England over financial crises and threats of revolution spreading from the continent. The Irish threat to England was given concrete form in the masses of Irish immigrants who fled their own country in search of relief and employment. The 1848 Chartist petition appeared to presage possible class conflict in England; and although fears of an outright social explosion had died down by the beginning of the 1850s, the threat of moral contamination of English workers by the Irish remained.

This apparent danger fueled both physical and conceptual separation of English and Irish. Conflict, and especially cooperation, of English and Irish workers had to be prevented. Assimilation was in this respect a patently inappropriate ideal to pursue. Assimilation in the form of the extension of English laws and liberties to Ireland was also 
inadvisable given the apparent necessity of harsh coercion measures there in order to prevent social unrest or revolution. The huge expenditures which the English believed they had made in 1846-1847 demonstrated the dangers of integration on another level, for the supposed unwillingness of the Irish to improve themselves, combined with their apparent ingratitude, made it seem that a continuation of liberal policies would entail endless expenditure for no clear return, at a time when England's economy seemed anything but stable. For most Englishmen spending too much in Ireland threatened not only to empty their own pockets, but also to enrage the English workers whom might be forced to share resources with the indolent Paddy.

Changes in scientific attitudes toward human nature did not at first drive, but were themselves driven by, events in Ireland and shifting political and economic priorities in that country. Irish unregeneracy as demonstrated by the events surrounding the famine lent racialists both physical 'proof' and, more importantly, an emotional edge to their theories. Anger at Irish ingratitude for, and unwillingness to make use of English relief funds was very widespread in the last years of the famine. Racialism provided an outlet for this anger at the same time as it conveniently shifted the blame for the Irish catastrophe from the English to the Irish themselves. It also proved its usefulness in providing a conceptual framework for the separation of English and Irish without weakening the dominant position of the former.

In the 1850s, though racialism no doubt proved convincing for some who studied the arguments of its theorists, it main function was to justify English attitudes toward the ever-growing number of Irish immigrants. Even as late as the 1860s the numbers remained high. In 1863 there were 117,000 recorded new Irish immigrants into England, 
while in 1864 it was 114,000 . These figures indicated a slight diminution, but in the later case the number was taken from a smaller population within Ireland itself, and the actual percentage of immigrants based on the total population of Ireland remained almost unaltered. ${ }^{1}$

Gender runs as a constant thread in English perceptions of Ireland throughout this period. This element of English discourse is traceable back to the beginnings of relations between the two countries. Several qualities of character generally associated with the Irish, particularly their simplicity, hospitality, vanity, emotionalism, and their love of music, poetry and folklore, were 'feminine' or childlike traits that had been ascribed to them by the English since the twelfth century. In the seventeenth century one English writer went so far as to compare Irish geography with the female anatomy. ${ }^{2}$

Here again what had changed in the first half of the nineteenth century was not the fundamentals of English thought, but its form, which in taking on the trappings of liberal theory found it necessary to embody its gendered conception of the Irish in a rhetoric of marriage. The weakening of liberalism in the aftermath of the Famine did not of course remove the gendered conception of Irish nature, but instead changed its form. The femininity of Irish nature was used not to justify complimentarily and assimilation, but to emphasize and reinforce differences in power and social freedom between the two peoples.

Irish subservience to England was an element of fundamental continuity in English thought between 1820 and 1870, as indeed it had been for several centuries

\footnotetext{
${ }^{1}$ Lord Dunkellin, “Adjourned Debate Resumed,” House of Commons Debate, Vol 177 (February 27, 1865):756.

${ }^{2}$ John P. Harrington, The English Traveller in Ireland: Accounts of the Irish through Five Centuries (Dublin: Wolfhound Press, 1991), 15.
} 
before. In the early 1830s and 1840s, subservience was defined in terms usually of wife to husband, but also of student to teacher or patient to doctor. Ruling Ireland carried with it a moral duty to improve, instruct, or 'cure' the country so as to cement the bond of its union with Britain. In the 1850s, Ireland's role was increasingly seen as little more than to willingly serve. It would be untrue to say that the ruler had no moral duties. These duties had changed however, being limited to ruling Ireland in fairness and justice, having no element of moral or economic uplift aside from the mission to evangelize. Even the moral mission of evangelization, however, was never advanced as a means of raising the level of the Irish to near-equality, but as a way to make them happy where they were.

A strong element of continuity therefore underlay all of the changes that appeared on the surface of English perceptions of the Irish from 1820 to 1870. Whether the dominant note in English moods was of optimism or pessimism, Ireland always remained at best a junior partner in the union inhabited by people fundamentally different from the English. At no time in this period did the English public come to terms with the possibility that the Irish might be capable not only of cooperating with or imitating the English, but also of emulating, becoming independent from, and even outstripping the English in civilization, wealth and power. The rise of racialism was in this respect only what Edward Said has called a "codification of differences" that were already assumed to exist. $^{3}$

By the end of the 1860s, racial theory was deeply ingrained in the socio-political constructs of the British Empire. The scientific hierarchies of Man gave imperialism a sound and logical framework. The long and troubled history between England and

\footnotetext{
${ }^{3}$ Edward Said, Culture and Imperialism (New York: Vintage, 1994), 130.
} 
Ireland seemed to culminate in the ongoing crises of the period that extended in the later decades of the 1800s as well. As late as 1895, popular sentiment flared against perceived damage the Irish had wrought upon England over the decades. Father Morris, an English Catholic, stressed the impact the "steady flow of Irish" from the "famine of 1845" had on the Catholic community in England, and it was, in his opinion, entirely negative. He believed that almost "every priest has to regret for many of his flock" that the Irish had ever come to England. Father Morris insisted that alcohol had "despoiled them of their good qualities, and made them neglect their religion" as they filled the "slums of English towns" and lived "crowded together in wretched rooms."

By the late 1860s, the English popular press had woven a distinctly negative narrative around the Irish people, particularly those in England. This narrative created and defined a reality about the Irish, a reality based partially on fact, partially on perception, and partially on the pseudo-sciences of the time. In developing this system of reference, the press invented a collection of images that shaped this identity for the Irish and implanted it firmly into the collective thoughts of middle class England. The media defined the Irish other and the middle class accepted that negative definition for a complex set of reasons. ${ }^{5}$ The Famine had taxed the goodwill of England and the rising violence only added to the frustration and weariness. As the Irish flooded the northern ports, they brought the problems of the other onto English soil. They were a tainted, backward people and the middle class simply had had enough of it after five decades. To the English, it was convenient to believe that the ills of Ireland and its people stemmed

\footnotetext{
${ }^{4}$ F.W. Farrar, "The Asserted Growth of Roman Catholicism in England,” Fortnightly Review 58:346 (October, 1895): 559.

${ }^{5}$ Steve Martinot, The Rule of Racialization: Class, Identity, and Governance (Philadelphia: Temple University Press, 2003), 184-185.
} 
from "their own weakness, their own prejudices, their own narrow views, [and] their own hostility to each other. ${ }^{\prime 6}$ As the metalanguage of race redefined the social hierarchies into scientific hierarchies in the latter half of the nineteenth century, the Irish were to become the racially inferior subclass of the British Isles.

A critical question to this discussion is why the English middle class felt that this negative image of the Irish was so imperative. Why did it become so pervasive by the end of the century? Why did it continue even when many in England seemed to support Home Rule in the 1880s? Why did it continue when England was faced with an even more racially different other in Africa? Perhaps these immigrants were becoming a troubling financial burden that a charity-conscious middle class wanted to simply eliminate.

Positioning the Irish in this manner gave the English middle class the moral justification they needed to control their charitable purse strings far tighter. The tax burden from the heavy flow of immigration was increasing steadily, particularly in the industrial centers of the north. As the years passed, the moderate and supportive voices, such as Mill, Foster, and Tuke, became less important to the middle class as they interpreted the vast quantity of information put before them. There had to be a way to ease the growing financial burden of the poor without seeming uncharitable. By defining a large portion of those poor as degenerate, subhuman creatures unable to be helped, they could then be stricken from the poor rolls without guilt.

In his article, "The Role of Guilt in the Formation of Modern Society: England 1350-1800," John Carroll argues that as England evolved, guilt increasingly became a

\footnotetext{
${ }^{6}$ MP Roebuck, “Adjourned Debate Continued,” House of Common Debate, Vol 177 (February 27, 1865): 750.
} 
tool of both self-government and social government. In the stages of guilt formation, the Victorian Era was defined by "civilized guilt” infused with an older "parricidal guilt" similar to that of the late 1600 s. $^{7}$ Civilized guilt, Carroll posits, is characterized by a greater secularity, with conduct becoming more temperately controlled. Institutions, such as government, become more rationally bureaucratic. Art and culture is "lighter, more ephemeral, and interested in manners and style." ${ }^{8}$ Personal hygiene and refining domestic practices become common. The body and its functions become private. Spitting and eating with fingers, for example, become socially unacceptable. Order and discipline is the socio-political norm. The energies of the middle class are directed not exclusively at religion, but also into commerce and the betterment of everyday living. ${ }^{9}$

This "civilized guilt" was not, however, the only form of guilt in the Victorian Era. In the late 1700s, the social norms relaxed considerably, particularly in relation to sex. Adultery, mistresses, contraception, and prostitutes were not merely tolerated Carroll argues, but they became the norm among the upper classes. Carroll points out that premarital pregnancies increased radically during the late seventeenth century and illegitimacy rose from roughly two percent to six percent between 1720 and $1780 .{ }^{10}$ In response to this growing decadence of the upper classes, the middle class of England returned to a more conservative lifestyle that included an older form of guilt known as "parricidal guilt” that was common from approximately 1600 through 1660 in the Puritans. Parricidal guilt is typified by the predominance of harsh religious beliefs. God is punitive, distant, and all-powerful, thus making Man sinfully low and worthless.

\footnotetext{
${ }^{7}$ John Carroll, "The Role of Guilt in the Formation of Modern Society: England 1350-1800,” The British Journal of Sociology, Vol. 32, No. 4 (December: 1981): 461.

${ }^{8}$ Ibid, 480.

${ }^{9}$ Ibid, 480 .

${ }^{10}$ Ibid, 479-480.
} 
Religion is then mirrored in a strongly patriarchal family. ${ }^{11}$ John Tosh's work on masculinity in the Victorian period emphasizing the dominant role of the patriarch in the domestic circle reinforces Carroll's conclusions. The Victorians harkened back to the more strict values of earlier English society while retaining the primary characteristics of “civilized guilt” as well.

It is critical to understand the role of guilt in Victorian society in order to understand how powerful it was as a motivating socio-political factor. The Victorians believed in temperance, rationality and commerce. At the same time, they valued strict social order and narrow values. Morality, defined through character, was critical to the Victorian period. Propriety, manners, and custom governed their daily lives. Charity was a part of this proper conduct. Peter Shapley argues that for the middle class Victorian, involvement with local charities, meant associating with "notions of care, benevolence and Christian duty.” This involvement created the image of an altruistic and morally upstanding member of the community. The press, Shapley posits, elevated charitable leaders to near-veneration, thus creating a critical element to the discourse of charity in this period. Charity was a vital means of acquiring or reinforcing symbolic social positions. These were individuals who displayed immense moral worth and value to the community. ${ }^{12}$ Charity was, therefore, deeply connected to the Victorian sense of selfworth, public worth, and guilt. Discontinuing charity was unthinkable, but the Irish were pushing the middle class beyond their charitable limits. How were they to solve this moral and financial dilemma? The answer was to use the pseudo-sciences and negative press to create a subhuman creature biologically unworthy of charity.

\footnotetext{
${ }^{11}$ Ibid, 473.

${ }^{12}$ Peter Shapley, “Charity, Status and Leadership: Charitable Image and the Manchester Man,” Journal of Social History, Vol. 32, No. 1 (Autumn, 1998): 157.
} 


\section{A Convenient Truth Fulfilled?}

This use of pseudo-science as a tool to create the other was extremely convenient for the English middle class ratepayer. It is a reasonable assumption that some, if not many, of the middle class did not believe the hateful rhetoric in its entirety. Historians, such as Gilley and Swift, have argued their racism was more a general dislike and quite different from the steaming rants of Thomas Carlyle. Dissenting opinions appeared in the popular press and there was not a national consensus of hate as L.P. Curtis has argued. Depicting the Irish so negatively did, however, serve a very concrete economic purpose. As the welfare state evolved in the early and mid-1800s, the role of government charity became central to a democratic society based on liberty and freedom. This sort of state could not revert to Thomas Carlyle's image of a feudal society as he argued in his essay "The Negro Question."13 The state could also not continue to support the ever-increasing numbers of immigrants from across the Irish Sea. As they brought disease, poverty and crime to English shores, the middle class needed a way to remove the tax burden these people were creating without seeming callous. In prior decades, this conundrum had no answer. By the 1860s, however, science provided that answer.

This manipulation of government and public opinion is called, according to French theorist Michel Foucault, governmentality. The concept of governmentality essentially develops a new understanding of power. Foucault defines power not only in terms of the hierarchical, top-down power of the state, but also the forms of social control in disciplinary institutions, such as schools, hospitals, or psychiatric institutions. Power, he posits, can manifest itself by producing knowledge and certain discourses that are then internalized by individuals. Once internalized, this knowledge guides the behavior of

\footnotetext{
${ }^{13}$ Thomas Carlyle, “The Negro Question,” Fraser's Magazine for Town and Country, (London, 1849).
} 
populations. This leads to more efficient forms of social control, as knowledge enables individuals to govern themselves. This social control has both positive and negative aspects as it can be used to increase participation in a democratic society. Conversely, it can be used to exclude groups or individuals that stand outside of the way the larger body has internalized and interpreted specific knowledge. While Foucault acknowledges that governmentality is applicable throughout history, he stresses that it is best applied to modern, liberal democracies. It is in this setting, with a strong public sector involved in the political process, where the interchange of knowledge, power and internalization occurs. $^{14}$

Using Foucault's theory of governmentality, Mitchell Dean positions the discourse and practices of governing the destitute, an idea central in the formation of a liberal capitalist society, directly within the economic, political and social history of nation, particularly Victorian England. Pauperism, according to Dean, is not an abstract concept, but a reality that governments and a larger population must address. Dean’s analysis challenges the liberal government's stance as a purely economic self-regulating system, but it also contradicts the Marxist view that moral regulation is an unimportant facet in purely economic class relations. Dean accomplishes this complex argument through his analysis of the liberal state's role in constituting subjectivities. The state essentially creates a discourse on a subject in order to manipulate and control opinion on that subject.

In his work The Constitution of Poverty, Dean shows that gender, family, and sexual relations in Victorian England were not outside economics or determined by

\footnotetext{
${ }^{14}$ Michel Foucault, “Governmentality,” in The Foucault Effect: Studies in Governmentality, trans. Rosi Braidotti and revised by Colin Gordon, eds. Graham Burchell, Colin Gordon and Peter Miller, (Chicago: University of Chicago Press, 1991), 87-104.
} 
economics, but were instead necessary factors in liberal economic and social policy. Malthus' catastrophic model, for instance, rested on the ideal of the Victorian male breadwinner. Men were assumed to make all reproductive as well as economic decisions and women were assumed to derive their status from that of men. This assumption of a particular moral code was then carried over into the 1834 Poor Law revisions in England. Single women without children, for example, were totally ignored, while widows with children were stuffed into the category of 'non-able-bodied' regardless of their health. In contrast, mothers of illegitimate children, whatever their health, were treated as "sturdy Beggars” and offered only the workhouse as an option for relief. ${ }^{15}$

Dean develops the Foucaultian view that the economic structure characterized by the binary relationship between wage labor and pauperism is in reality a mode of moral regulation just as much as it is a new type of distribution system or a new mode of production. A liberal government is not indifferent to the non-economic features of working class and middle class life. This form of government actually requires and constructs a certain gender and household organization through specific moral and sexual practices. He argues that in the Victorian Era, this was encapsulated in the word 'character.' That single word captures all the substantive psychological and ethical codes of the time.

Rather than laissez-faire, liberalism is instead a new mode of regulating life. The liberal distinction between mere poverty and pauperism became, in reality, a moral distinction. In England, distinct classifications divided the needy as either moral and able to be helped or vicious and degenerate. They were defined, in essence, by their character.

\footnotetext{
${ }^{15}$ Mitchell Dean, The Constitution of Poverty: Towards a genealogy of liberal governance, (London: Routledge, 1991), 161, 169.
} 
In doing so, the English middle class could effectively cleanse their moral souls of those paupers labeled degenerate in order to concentrate their efforts on those capable of saving. By assigning the Irish poverty to biology and characterizing them as degenerates, they could be stricken from the pauper rolls. This served multiple ends. First, it simply saved the ratepayers a great deal of money. Second, it defined a growing, problematic group as the other and maintained the Victorian sense of charity without actually helping those most needy. Thirdly, it separated the growing Irish population within England from the larger English identity and helped preserve what Graham MacPhee and Prem Poddaer identified as that internal sense of Englishness within the larger imperial sense of Britishness.

This study examines the origins of the hostile view of the Irish, but it raises numerous questions about the later decades of the century. Were middle class aims achieved, thus reducing the pauper rolls? If so, how did the middle class benefit? If those aims were not achieved, is this perhaps a possible source of the increased hostility as reflected in the popular media? What role did Home Rule and the threat to the Empire play? Further research into the socio-political changes during the last decades of the century is needed. What is clear, however, is the ever-increasing complexity in AngloIrish relations contained an undercurrent of hostility throughout the Victorian Era as the English middle class responded to the numerous crises of the period. 


\section{Bibliography}

\section{Primary Sources}

\section{Government Publications}

Great Britain, Census of Great Britain, 1851. Population Tables. I. Numbers of the Inhabitants, in the years 1801, 1811, 1821, 1831, 1841, and 1851: Volume I. London: William Clowes and Sons, 1852.

Great Britain, Correspondence From July, 1846, to January, 1847, Relating to the Measures adopted for the Relief of the Distress in Ireland. Board of Works Series. London, William Clowes and Sons, 1847.

Great Britain, Destitute Irish (Liverpool). Copies of, or extracts from, any correspondences address to the Secretary of State for the Home Department, relative to the recent immigration of destitute Irish into Liverpool. London: S.M. Phillips, 1847.

Great Britain, First Report of the Commissioners For Inquiring into the State of Large Towns and Populous Districts. London: William Clowes and Sons, 1844.

Great Britain, First report of Evidence from The Select Committee on the State of the Poor in Ireland. Minutes of Evidence: 24 March-14 May, 589: II. June 30, 1830.

Great Britain, Fourth Annual Report of the Registrar-General of Births, Deaths, and Marriages In England. London: William Clowes and Sons, 1842.

Great Britain, Eleventh Annual Report of the Poor Law Commissioners with Appendices. London: William Clowes and Sons, 1845.

Great Britain, House of Commons Debates, 1847 - 1868.

Great Britain, House of Lords Debates, 1866 - 1868.

Great Britain, Irish Steamers. Captain Denham's Report on Passenger Accommodations in Steamers between Ireland and Liverpool. London: Steam Navigation Department Board of Trade, 1849.

Great Britain, Miscellaneous Statistics of the United Kingdom, 1857-58. London: George Edward Eyre and William Spottiswoode, 1857.

Great Britain, The Parliamentary Debates (Authorized Edition) Volume 118. London: H. M. Stationery Office, 1851.

Great Britain, Parliamentary Papers, 1835 - 1842. 
Great Britain, The Poor Law Commission. London: G. Luxford, 1846.

Great Britain, Report of a Committee of the Council of the Statistical Society of London, consisting of Lieut.-Colonel W.H. Sykes, V.P.R.S., Dr. Guy, and F.G.P. Neison, Esq., to their dwellings in Church Lane, St. Giles's. 1848.

Great Britain, Report of the Constabulary Commission, 18 S. London, 1839.

Great Britain, Report to Her Majesty's Principal Secretary of State for the Home Department from the Poor Law Commissioners of the Labouring Population of Great Britain with Appendices. London: William Clowes and Sons, 1842.

Great Britain, Report from the Select Committee on the Laws Relating to Irish and Scotch Vagrants. 1829.

Great Britain, Report on the State of the Irish Poor in Great Britain. London: G. Luxford, 1836.

Great Britain, Reports and Communications on Vagrancy. London: William Clowes and Sons, 1848.

Great Britain, Sanitary Inquiry:- England Local Reports on the Sanitary Condition of the Labouring Population of England, in Consequence of an Inquiry to be made by the Poor Law Commissioners. London: William Clowes and Sons, 1842.

Great Britain, Seventh Annual Report of the Poor Law Commissioners with Appendices. London: William Clowes and Sons, 1841.

Great Britain, State of the Poorer Classes in Great Towns. Substance of a speech in The House of Commons, February 4, 1840, on Moving for A Committee to Consider the Cause of Discontent. London: Longman and Co., 1840.

Great Britain, Third Report of the Commissioners for Inquiring into the Condition of the Poorer Classes in Ireland. London: G. Luxford, 1836.

Great Britain, Variation of the death rate in England: being the substance of a paper read before the Committee of the Manchester and Salford Sanitary Society. Manchester: Cave \& Sever, 1860.

\section{Newspapers, Magazines and Pamphlets}

The Aberdeen Journal, 1847.

Black Dwarf, 1822 - 1824. 
Blackwood's Edinburgh Magazine, 1836 - 1848.

The Bristol Mercury, 1847.

British and Foreign Review, 1840.

Capital and Labour, 1874.

Cause of the People, 1848.

Chamber's Edinburgh Journal, 1847.

Chamber's Journal of Popular Literature, Science and Arts, 1895.

Critic, 1862.

The Derby Mercury, 1867.

The Dublin Evening Mail, 1827.

Dublin University Magazine, 1847 - 1868.

Eclectic Review, 1842.

The Economist, 1843 - 1847.

Edinburgh Monthly Review, 1819.

The English Patriot and Irish Repealer, 1848.

The Examiner, 1839 - 1852.

Family Herald, 1843.

Fortnightly Review, 1884 - 1895.

Fraser's Magazine for Town and Country, 1840 - 1873.

The Gentleman’s Magazine: Volume 34, 1850.

The Glasgow Courier, 1827.

Halifax Guardian, 1847.

Home and Foreign Review, 1862, 
Household Words conducted by Charles Dickens, 1851.

The Hull Packet and East Riding Times, 1847.

Illustrated London News, 1847 - 1852.

Illustrated Review: A Fortnightly Journal of Literature, Science and Art, 1870.

The Illustrated Times, 1867.

The Leader, 1851.

Leeds Mercury, 1847.

Liverpool Albion, 1847.

Liverpool Courier, 1847.

Liverpool Journal, 1847.

The Liverpool Mail, 1851.

The Liverpool Mercury, 1847 - 1848.

Liverpool Standard, 1847.

Lloyd's Entertaining Journal, 1845.

Lloyd's Weekly Miscellany, 1850-1852.

London Examiner, 1839 - 1840.

London Quarterly Review, 1868.

London Review of Politics, Society, Literature, Art and Science, 1863 - 1866.

London Society: An Illustrated Magazine of Light and Amusing Literature for the Hours of Relaxation, 1868.

Macmillan’s Magazine, 1869.

Manchester Courier, 1851.

Manchester Guardian, 1847 - 1852.

The Manchester Times and Gazette, 1847. 
Methodist Magazine, 1813.

The Morning Chronicle, 1830 - 1850.

Nation, 1845 - 1849.

New Monthly, 1882.

New Quarterly Magazine, 1879.

NewCastle Guardian, 1847.

The Nineteenth Century: A Monthly Review, 1886.

North British Review, 1867.

Northern Star, 1837 - 1848.

The Northern Star and National Trades’ Journal, 1847.

Once A Week, 1862.

Owen, Robert and John Brindley. What is Socialism?: and what would be its practical effects on society (Home Colonization Society, 1841).

The Pall Mall Gazette, 1883.

The Preston Guardian, 1846.

People’s Press, 1848.

Punch, $1843-1848$.

Rambler Volume II New Series, 1860.

The Six Points of the People's Charter. Taken from a broadsheet published in 1838. Accessed July 122010 http://web.bham.ac.uk/1848/document/peoplech.htm.

Stockport Advertiser, 1852.

The Times, 1848 - 1879.

United Irishman, 1848.

Universal Magazine, 1802 - 1807. 
Weekly Dispatch, 1848.

Wesleyan Methodist Magazine, 1854.

Westminster Review, 1849.

Stokes, Whitley. "The Irish Abridgement of the Expugnatio Hibernica." English Historical Review XX (1905): 77-115.

\section{Books and Journals}

Adams, William Edwin. Memoirs of a Social Atom. London: Hutchinson \& Co, 1903.

Alzog, John. Manual of Universal Church History: Volume 3. London: The Robert Clarke Co., 1903.

The Annual Register, or a view of the History and Politics of the year 1848. London: F \& J Rivington, 1849.

Arnold, Thomas. Inaugural Lecture on the Study of Modern History. Oxford: Parker, 1842.

Berkeley, George. A Treatise Concerning the Principles of Human Knowledge, translated annotations by Charles P. Krauth. Philadelphia: J.B. Lippincott, 1881.

Binney, T. "Short Essays.” The Evangelical Magazine and Missionary Chronicle, Volume V, New Series. London: Hodder and Stoughton, 1873.

Boase, Frederic. Modern English Biography. London: Netherton and Worth, 1897.

Carlyle, Thomas. Chartism, Second Edition. London: James Fraser, 1840.

Carlyle, Thomas. Reminiscences of My Irish Journey in 1849. New York: Harper and Brothers, 1882.

Carlyle, Thomas. The Works of Thomas Carlyle: 30 Volumes. Vol. XXIX. London: 1898.

Cayley, Edward Stillingfleet. The European Revolutions of 1848, Volume III. London: Smith, Elder \& Co., 1856.

Chambers, Robert. Vestiges of the Natural History of Creation 1844. New York: Humanities Press, 1969. 
Cobden, Richard. Speeches on Question of Public Policy, Volume III. London: MacMillan, 1870.

Collier, W.F. History of the British Empire. London: T. Nelson and Sons, 1859.

Combe, George. Lectures on Phrenology. New York: Samuel Colman, 1839.

Cooper, Thomas. Wise Saws and Modern Instances: Volume II. London: Jeremiah How, 1845.

Darwin, Charles. The Descent of Man. London: D. Appleton and Co., 1871.

Devoy, John. Recollections of an Irish Rebel 1929. New York: Chas. D. Young, 1929.

Dilke, Charles Wentworth. Greater Britain: A Record of Travel in English-Speaking Countries, 1866 and 1867. London: Macmillan and Co., 1868.

Dill, Edward Marcus. The Mystery Solved: or Ireland's Miseries; The Grand Cause, and the Cure. Edinburgh: Johnstone and Hunter, 1852.

Disraeli, Benjamin. Sybil. New York: Oxford University Press, 1981.

Doheny, Michael. The Felon's Track. Dublin, M.H. Gill and Son, 1920.

Dufferin and the Hon. G.F. Boyle. Narrative of a Journey from Oxford to Skibbereen during the year of the Irish Famine. Oxford: John Henry Parker, 1847.

Engels, Frederic. The Conditions of the Working Class in England. Oxford: Basil Blackwell, 1958.

Ellis, George. Irish Ethnology Socially and Politically Considered: Embracing a General Outline of the Celtic and Saxon Races; with Practical Inferences. London: Hamilton, Adams and Co., 1852.

Fairy Legends and Traditions in the South of Ireland. London: John Murray, 1828.

Father Mathew: A Biography. London: Spottiswoode and Co., 1865.

The Female Instructor. London: H. Fisher, Son, and P. Jackson, 1836.

Froude, James Anthony. The English in Ireland in the Eighteenth Century. London: Longmans, Green and Co., 1872.

Gammage, Robert George. The History of the Chartist Movement, 1837-1854. Newcastle-on-Tyne: Browne \& Browne, 1894. 
Grant, Henry. Ireland's Hour. London: Thomas Hatchard, 1850.

Greville, Charles. The Greville Memoirs: Volume II. New York, D. Appelton, 1885.

Haydn, Joseph. Haydn's dictionary of dates relating to all ages and nations: for universal reference. London: E. Moxon and Co., 1866.

Heginbotham, Henry. Stockport Ancient and Modern, Volume One. 1882.

Inglis, Henry D. A View of the State of pauperism in Ireland; Its Evils and Its Remedies. London: J. Ridgway and Sons, 1836.

Kent, Clement Boulton Roylance. The English Radicals: A Historical Sketch. London: Longmans, Green and Co., 1899.

King, W.H. Account of the Fisheries in 1822 on the Western Coast of Ireland. Dublin, 1823.

Kingsley, Charles. His Letters and Memories of his Life, ed. Francis E. Kingsley III. London: MacMillan, 1901.

Knox, Robert. The Races of Men: A Fragment. London: Lea \& Blanchard, 1850.

Knox, Robert. The Races of Men: A Philosophical Inquiry into the Influence of Race over the Destinies of Nations, Second Edition. London: Henry Renshaw, 1862.

The Later Correspondence of George III: Volume I, ed. Arthur Aspinall. Cambridge: Cambridge University Press, 1962.

Legends, Tales and Stories from Ireland. Dublin: John Cumming, 1837.

Life and Letters of Sir James Graham, 1792-1861, Volume II, ed. C.S. Parker. London, 1907.

Lilly, William Samuel. Studies in Religion and Literature. London: Chapman \& Hall, ld., 1904.

Lovett, William. Life and Struggles of William Lovett in his pursuit of bread, knowledge and freedom. London: Trbner Publishing, 1876.

Kames, Sketches of the History of Man, Volume Two. Edinburgh, 1788.

Maberly, K.C. The Present State of Ireland, and Its Remedy. London: James Ridgway, 1847. 
Manners, John. Notes of an Irish Tour. London: J. Ollivier, 1849.

Massy, Richard Tuthill. Analytical Ethnology: The Mixed Tribes of Great Britain and Ireland Examined, and the Political, Physical and Metaphysical Blunderings on the Celt and Saxon Exposed. London: H. Bailliere, 1855.

Maxwell, William Hamilton. History of the Irish Rebellion in 1788. London: Baily Brothers, 1845.

Mayhew, Henry and John Binny. The Criminal Prisons of London and Scenes of Prison Life. London: griffin, Bohn and Company, 1862.

McCulloch, John Ramsay. A Descriptive and Statistical Account of the British Empire: Volume I. London: Longman, Brown, Green, and Longmans, 1854.

Mill, John Stuart. Collected Works of John Stuart Mill. Canada: University of Toronto Press, 1986.

"Minister of the Gospel." The True Source and End of Ireland's Destitution; together with an Appeal, to British Christians, on Behalf of Ireland. London: John Snow, 1849.

Mitchel, John. The Crusade of the Period. London: Lynch, Cole \& Meehan, 1873.

Mitchel, John. Jail Journal: or five years in British prisons. New York: Office of the Citizen, 1854.

Mitchel, John. The Last Conquest of Ireland (perhaps). Glasgow: Cameron \& Ferguson, 1876).

The Moderate Cavalier; or the Soldiers Description of Ireland, A Book fitt for all Protestants Houses in Ireland. Cork, 1675.

The Monthly Review From May to August Inclusive, Volume II. London: G. Henderson, 1836.

Morton, Samuel G. Crania Americana. Philadelphia, 1939.

Motives for Mission: A Series of Six Lectures Delivered before the Church of England Young Men's Society, ed. Rev. Thomas Nolan. London: Sampson, Low and Son, 1852.

Newman, John Henry. The Idea of A University, Reprint. London: Longman's, Green and Co. 1891. 
Nicholson, Asenath. Annals from the Famine in Ireland In 1847, 1848, and 1849. New York: E. French, 1851.

Nicholson, Asenath. Ireland's Welcome to the Stranger. Or An Excursion through Ireland in 1844, 1845, for the Purpose of Personally Investigating the Conditions of the Poor. New York: Baker and Scriber, 1847.

O’ Connell, Daniel. Ireland and O’Connell. England: Tait, 1835.

Osbourne, S. Godolphin. Gleanings in the West of Ireland. London: 1850.

Owen, Robert. The Life of Robert Owen: Volume I. England: Wilson, 1858.

Owen Robert and John Brindley, What is Socialism?: and what would be its practical effects on society. Home Colonization Society, 1841.

Pike, Luke Owen. History of Crime in England Illustrating the Changes of the Laws in the Progress of Civilisation: Written from the Public Records and Other Contemporary Evidence Volume II. London: Smith, Elder, and Co. 1876.

The People's Press and Monthly Historical Newspaper, ed. William Shirrefs. Vol. II. London: James Watson, 1848.

Scrope, George Poulett. How To Make Ireland Self-Supporting; or, Irish Clearances, and Improvements of Waste Lands. London: James Ridgeway, 1848.

Senior, Nassau William. Journals, Conversations and Essays Relating to Ireland: Volume Two. London: Longmans, Green and Co., 1868.

Short Studies on Great Subjects, Third Edition. London: Longmans, Green and Co., 1868.

Shuttleworth, James Phillips Kay. The Moral and Physical Condition of the Working Classes Employed in the Cotton Manufacture in Manchester, Second edition. London: Frank Cass and Co. Ltd., 1970.

Smith, Charles Hamilton. The Natural History of the Human Species. London: W.H. Allen and Co., 1848.

Smith, George Lewis. Ireland: Historical and Statistical. London: Whittaker \& Co., 1849.

Smith, Goldwin. Irish History and Irish Character. London: J.H. and Jas. Parker, 1862.

Ó Súileabháin, Amhlaoimh. The Diary of Humphrey O’Sullivan. Dublin: Irish Texts Society Simpkin, Marshall, 1936. 
Taylor, Isaac. The Origins of the Aryans: An Account of the Prehistoric Ethnology and Civilisation of Europe. Scribner and Welford, 1890.

Thom's Irish Almanac and Official Directory of the United Kingdom. Dublin: Alexander Thom and Sons, 1857.

Thom's Statistics of Great Britain and Ireland. Dublin: Alexander Thorn, 1868.

Tighe, William. Statistical Survey of County Kilkenny. Dublin, 1802.

Trevelyan, Charles. The Irish Crisis. London: Longman, Brown, Green and Longmans, 1848.

Tuke, James. A Visit To Connaught in the Autumn of 1847: A Letter addressed to the Central Relief Committee of the Society of Friends, Dublin, Second Edition. London: C. Gilpin, 1848.

Wakefield, Edward. An Account of Ireland, Statistical and Political: Volume I. London: Longman, Hurst, Reese, Orme, and Brown, 1812.

Walsh, John. On Reform of Parliament; and on Ireland. London: James Ridgway, 1831.

Webb, Beatrice and Sidney. History of Trade Unionism. London: Longman, Green and Co, 1894.

West, Theresa Cornwallis I. Whitby. A Summer Visit to Ireland in 1846. London: R. Bentley, 1847.

Wylie, J.A. Rome and Civil Liberty. London: Kessinger Publishing, LLC, 1865.

\section{Other Select Sources}

The Annals of Ulster, trans. Mac Airt \& Mac Niocaill, T100001A. The Corpus of Electronic Texts, 2000.

Curtis, E. and R.B. McDowell. Irish Historical Documents. London: Methuen, 1943.

English Historical Documents ed. W. D. Handock. New York: Oxford University Press, 1977. 


\section{Secondary Sources}

\section{Articles and Conference Publications}

Busteed, Mervyn. “The Irish in Nineteenth Century Manchester.” Irish Studies Review, 18 (Spring, 1997): 8-31.

Busteed, Mervyn and R.I Hodgson. "Irish Migrant Responses to Urban Life in Early Nineteenth-Century Manchester.” The Geographical Journal, Vol. 162, No. 2 (July: 1996): 137-153.

Carroll, John. "The Role of Guilt in the Formation of Modern Society: England 1350 1800.” The British Journal of Sociology, Vol. 32, No. 4 (December: 1981): 459 503.

Clapham, J.H. "Irish Immigration into Great Britain in the Nineteenth Century.” Bulletin of the International Committee of Historical Sciences, 20 Vol. 5 (July 1933): 496505.

Donnelly Jr, James S. “The Construction of the Memory of the Famine in Ireland and the Irish Diaspora, 1850-1900.” Éire-Ireland, 31 (Spring/ Summer 1996): 26-61.

Edge, Sarah Jane. "Photographic History and the Visual Appearance of an Irish Nationalist Discourse 1840-1870.” Victorian Literature and Culture, Vol. 32, No. 1 (2004): 17-39.

Gibbons, Luke. “Race against Time: Racial Discourse and Irish History.” Oxford Literary Review13 (1991): 95-117.

Goodway, David. “Chartism in London.” Bulletin for the Society for the Study of Labour History 20 (1970).

Gray, Peter. "British Public Opinion and the Great Irish Famine 1845-49.” Comhdhail an Chroaibhin: conference proceedings, ed. B. O'Conaire (Ireland: Irish Academic Press, 1995): 56-74.

Jones, W.R. "England Against the Celtic Fringe: a study in cultural stereotypes.” Journal of World History, 13 (1971): 155-171.

Kinealy, Christine. "Beyond Revisionism: Reassessing the Great Irish Famine.” History Ireland, 3/4 (Winter, 1995): 28-34.

Kenny, Kenny. "Diaspora and Comparison: The Global Irish as a Case Study.” The Journal of American History, Vol. 90, No. 1 (June, 2003): 134-162. 
Lindert, Peter H. and Jeffrey G. Williamson, “English Workers’ Living Standards During the Industrial Revolution: A New Look.” Economic History Review, 36 (February, 1983): 1-25.

Martin, Amy. “Blood Transfusions: Constructions of Irish Racial Difference, the English Working Class, and Revolutionary Possibility in the Work of Carlyle and Engels.” Victorian Literature and Culture, Vol. 32, No. 1 (2004): 83-102.

Maehl, W. H. "The dynamics of violence in Chartism: a case study in northeastern England.” Albion, vii (1975), 101-119.

Moore, D.C. “The Corn Laws and High Farming,” Economic History Review, Second Series, XVIII (1965): 544-561.

Neal, Frank. “A Criminal Profile: The Liverpool Irish” Transactions of the Historic Society of Lancashire and Chesire, Volume 140, (1991): 165-181.

Ní Ghabhann, Gillian. “A Critical Examination of A Selection of Travel Writing Produced During the Great Famine.” Chronicon, (1997): 1-57.

Ó Tuathaigh, M.A.G. “The Irish in Nineteenth-Century Britain: Problems of Integration.” Transactions of the Royal Historical Society, $5^{\text {th }}$ Series 31 (1981): 146-161.

Prothero, Iorworth. “Chartism in London,” Past and Present, 44 (August, 1969): 76-105.

Reader, John. “The Fungus That Conquered Europe.” New York Times. March 17, 2008.

Sivanandan, Ambalavaner. “Challenging Racism: Strategies for the 80s.” Race and Class 25, No. 2 (Autumn 1983): 1-11.

Shapley, Peter. "Charity, Status and Leadership: Charitable Image and the Manchester Man.” Journal of Social History, Vol. 32, No. 1 (Autumn, 1998): 157-177.

Smedley, Audrey. “'Race’ and the Construction of Human Identity,” American Anthropologist, New Series Vol. 100 No. 3 (September 1998): 686-701.

Soss, Joe and Sanford F. Schram, “A Public Transformed? Welfare Reform as Policy Feedback.” The American Political Science Review, Vol. 101, No. 1 (February, 2007): 111-127.

Steele, E.D. “The Irish Presence in the North of England, 1850-1914,” Northern History, 12 (1976): 219-231.

Swift, Roger. "Heroes or Villains? The Irish, Crime, and Disorder in Victorian England," Albion: A Quarterly Journal Concerned with British Studies, Vol. 29 No. 3 (Autumn, 1997): 395-417. 
Thompson, Dorothy. "Chartism as a historical subject," Bulletin of the Society for the Study of Labour History, xx (1970).

Treble, J.H. “The Navvies,” Scottish Labour History Society Journal 5 (1973): 34-54.

Watt, J.A. “Negotiations between Edward II and John XXII Concerning Ireland.” Irish Historical Studies, No. 37, X (March 1956): 1-20.

Wilkinson, D. "How did they pass the union? Secret Service expenditures in Ireland 1799-1804,” History 82 (1997), 245-259.

Williamson, Jeffrey. "The Impact of the Irish on British Labor Markets During the Industrial Revolution,” The Journal of Economic History, Vol. 46, No. 3, (September, 1986): 693-720.

\section{Books}

Acts of Union: The Causes, Contexts and Consequences of the Act of Union, ed. Dáire Keogh and Kevin Whelan. Dublin: Four Courts Press, 2001.

Akenson, Donald H. An Irish History of Civilization. London: McGill-Queen's Press, 2005.

Anderson, Benedict. Imagined Communities. New York: Verso Books, 2006.

Anglo-Saxonism and the Construction of Social Identity. eds. Allen Frantzen and John Niles. Florida: University Press of Florida, 1997.

Balmford, Ramsden. Some Social and Political Pioneers of the Nineteenth Century. London: G. Allen, 1900.

Banton, Michael. Racial Theories. Cambridge: Cambridge University Press, 1987.

Bartlett, Thomas. The Fall and Rise of the Irish Nation: The Catholic Question 1690 1830. London: Dill and MacMillan, 1992.

Becoming National: A Reader, ed. Geoff Eley and Ronald Grigor Suny. Oxford: Oxford University Press, 1996.

Being Poor In Modern Europe: Historical Perspectives 1800-1940. ed. Inga Brandes. London: Peter Lang, 2006.

Bourke, Austin. The Visitation of God? The Potato and the Great Irish Famine. Dublin, Lilliput Press, 1993. 
Brake, Laurel and Marysa Demoor, Dictionary of Nineteenth Century Journalism in Great Britain and Ireland. Belgium: Academia Press, 2009.

The Cambridge Economic History of Europe: Volume VII: The Industrial Economies: Capital, Labour, and Enterprise, ed. P. Mathias and M.M. Postan. Cambridge: Cambridge University Press, 1978.

Canny Nicholas. Making Ireland British, 1580-1650. (Oxford: Oxford University Press, 2003).

Chapman, Malcolm. The Gaelic Vision in Scottish Culture. London: Croom Helm, 1986.

Chase, Malcolm. Chartism: A New History. England: Manchester University Press, 2007.

Claydon, Tony and Ian McBride. Protestantism and National Identity: Britain and Ireland, c.1650-c.1850. Cambridge: Cambridge University Press, 1998.

Clayton, Joseph. Robert Owen: Pioneer Of Social Reform. England: A. C. Fifield, 1908.

Cole, G.D.H. A Short History of The British Working Class Movement, 1789-1947. London: Routledge, 2001.

Colley, Linda. Britons: Forging the Nation, 1707-1837. New Haven: Yale University Press, 1992.

Concepts of National Identity in the Middle Ages, ed. Simon Forde, Lesley Johnson, and Alan Murray. Leeds: Leeds Texts and Monographs, 1995.

Constructions of Race, Place and Nation. ed. P. Jackson and J. Penrose. London: UCL Press, 1993.

Crowley, Tony. The Politics of Language in Ireland 1366-1922: A Sourcebook. London: Routledge, 2000.

Curtis, Edmund. A History of Ireland from Earliest Times to 1922. New York: Routledge, 2002.

Curtis, L. Perry. Anglo-Saxons and Celts: A Study of Anti-Irish Prejudice in Victorian England. Connecticut: University of Bridgeport, 1968.

Curtis, L. Perry. Apes and Angels: Irishman in Victorian Caricature. London: David and Charles, LPC, 1971.

Daly, Mary. The Famine in Ireland. Dublin: Dundalgan Press, 1986. 
Davidoff, Leonor and Catherine Hall. Family Fortunes, Revised Editions: Men and Women of the English Middle Class, Second Edition. London: Routledge, 2003.

Davis, Richard P. The Young Ireland Movement. Dublin: Gill and Macmillan, 1988.

Dean, Mitchell. The Constitution of Poverty: Towards a genealogy of liberal governance. London: Routledge, 1991.

Donnachie, Ian L. and George Hewitt, Historic New Lanark: The Dale and Owen Industrial Community Since 1785. Scotland: Edinburgh University Press, 1993.

Duffy, Peter. The Killing of Major Denis Mahon: a mystery of Old Ireland. New York: HarpersCollins, 2007.

Dunlop, Robert. Daniel O'Connell and the Revival of National Life in Ireland. England: G.P. Putnam, 1900.

Eagleton, Terry. Heathcliff and the Great Hunger. London: Verso, 1995.

Ellis, Steven G. Tudor Ireland: crown, community, and the conflict of cultures, 1470 1603. London: Longman, 1985.

Elton, Geoffrey. The English. Oxford: Blackwell, 1992.

Empire and After: Englishness in Postcolonial Perspective, ed. Graham MacPhee and Prem Poddaer. New York: Berghahn Books, 2007.

Eppley, Daniel. Defending Royal Supremacy and Discerning God's Will in Tudor England. England: Ashgate Publishing Limited, 2007.

Epstein, James. The Lion of Freedom: Feargus O'Connor and the Chartist Movement, 1832-1842. London: Croom Helm, 1982.

Erikson, Thomas Hylland. Ethnicity and Nationalism: Anthropological Perspectives,. London: Pluto Press, 1993.

Faverty, Frederic Everett. Matthew Arnold, The Ethnologist. Evanston: Northwestern University, 1951.

Finn, Margot. After Chartism: Class and Nation in English Radical Politics 1848-1874. Cambridge: Cambridge University Press, 2004.

Fitzpatrick, David. Oceans of Consolation: Personal Accounts of Migration to Australia. Australia: Melbourne University Press, 1995.

Foster, R.F. Modern Ireland (1600-1972). New York: Penguin Books, 1989. 
Foster, R.F. The Oxford Illustrated History of Ireland. Oxford: Oxford University Press, 1989.

The Foucault Effect: Studies in Governmentality. eds. Graham Burchell, Colin Gordon and Peter Miller. Chicago: University of Chicago Press, 1991.

Foucault, Michel. The Order of Things: An archaeology of the Human Sciences. New York: Vintage Books, 1973.

Frazer, D. Power and Authority in the Victorian City. Oxford: Blackwell, 1979.

Gallman, Matthew J. Receiving Erin's Children: Philadelphia, Liverpool, and the Irish Famine, 1845-1855. Chapel Hill: University of North Carolina Press, 2000.

Garrard, J. Leadership and Power in Victorian Industrial Towns 1830-80. Manchester: Manchester University Press, 1983.

Goodway, David. London Chartism, 1838-1848. New York: Cambridge University Press, 1982.

The Great Irish Famine, ed. Cathal Póirtéir. Dublin: Mercier Press, 1995.

The Great Famine: Studies in Irish History 1845-52, ed. Robert Dudley Edwards. London: Brown and Nolan, 1957.

Hall, Catherine. Civilizing Subjects: Metropole and Colony in the English Imagination 1830-1867. Chicago: University of Chicago Press, 2002.

Harrington, John. The English Traveller in Ireland: Accounts of the Irish through Five Centuries. Dublin: Wolfhound Press, 1991.

Harris, Bernard. The origins of the British welfare state: society, state, and social welfare in England and Wales, 1800-1945. London: Palgrave Macmillan, 2004.

Herbert, Michael. The Wearing of the Green: A Political History of the Irish in Manchester. London: Irish in Britain Representation Group, 2001.

Hibbert, Christopher. Queen Victoria: A Personal History. New York: De Capo Press, 2001.

Hickman Mary J. and Bronwen Walter. Discrimination and the Irish Community in Britain: A Report of Research Undertaken for the Commission for Racial Equality. London, 1997. 
Hilton, Boyd. The Age Of Atonement: The Influence of Evangelicalism on Social and Economic Thought, 1795-1865. New York: Claredon Press, 1988.

Hilton, Boyd. A Mad, Bad and Dangerous People? England, 1783-1846. Oxford: Claredon Press, 2006.

An Historical Geography of Ireland, ed. B.J. Graham and L.J. Proudfoot. London: Academic Press, 1993.

Harrison, John. Robert Owen and the Owenites In Britain and America. New York: Taylor \& Francis, 2009.

Hobsbawn, Eric. Nations and Nationalism Since 1780: Programme, Myth and Reality. Cambridge: Cambridge University Press, 1992.

Hosts, Immigrants and Minorities, ed. K. Dunn. New York: Folkstone, Dawson, Langholm, 1971.

Hovell, Mark. The Chartist Movement. Manchester: University Press, 1918.

The Hungry Stream: Essays on Emigration and Famine, ed. E. Margaret Crawford. Belfast: Queen’s University Belfast, 1997.

Hutchinson, Edward Prince. Immigrants and Their Children. New York: Wiley, 1956.

The Irish in the Victorian City, ed. Roger Swift and Sheridan Gilley. London: Croom Helm, 1985.

Irish Migration in Britain 1815-1914: A Documentary History, ed. Roger Swift. Cork: Cork University Press, 2002.

Jackson, P. and J. Penrose. Constructions of Race, Place and Nation. London: UCL Press, 1993.

Jackson, T.A. Ireland Her Own: An Outline History of the Irish Struggle for National Freedom and Independence. England: Cobbett Press, 1946.

Jordanova, Ludmilla. Sexual Visions: Images of Gender in Science and Medicine between the Eighteenth and the Twentieth Centuries. Brighton: Harvester Wheatsheaf, 1989.

Joyce, Patrick. Work, Society and Politics: the culture of the factory in later Victorian England. New Jersey: Rutgers University Press, 1980.

Kanter, Douglas. The Making of British Unionism, 1740-1848: Politics, Government and the Anglo-Irish Constitutional Relationship. Dublin: Four Courts Press, 2009. 
Kee, Robert. The Green Flag. London: Weidenfeld and Nicholson, 1972.

Kennedy, Dane. The Highly Civilized Man: Richard Burton and the Victorian World. Cambridge: Harvard University Press, 2005.

Kennedy, R.E. The Irish Emigration, Marriage and Fertility. London: University of California Press, 1973.

Kenny, Kenny. Ireland and the British Empire. England: Oxford University Press, 2004.

Kinealy, Christine. A Death-Dealing Famine: The Great Hunger in Ireland. London: Pluto Press, 1997.

Kinsella, Anna. County Wexford in the Famine Years 1845-1849. Ireland: Duffry Press, 1995.

Koepsell, Paul and Jay W. Pscheidt, 1994 Pacific Northwest Plant Disease Control Handbook. Corvallis: Oregon State University Press, 1994.

Lebow, Richard. White Britain and Black Ireland: the influence of stereotypes on colonial policy. New York: Institute for the Study of Human Issues, 1976.

Lewis, Brian. The Middlemost and the Milltown: Bourgeois Culture and Politics in Early Industrial England. Stanford: Stanford University Press, 2001.

Lightman, Bernard. Victorian Popularizers of Science: Designing Nature for New Audiences. Chicago: University of Chicago Press, 2007.

Lowe, William J. The Irish in Mid-Victorian Lancashire: the shaping of a working class community. New York: P. Lang, 1989.

Mac Atasney, Gerald. This Dreadful Visitation: The Famine in Lurgan/ Portadown. Belfast: Beyond the Pale, 1997.

MacDougall, H. Racial Myth in English History: Trojans, Teutons, and Anglo-Saxons. Canada: Harvest House, 1982.

MacIntyre, Angus. The Liberator: Daniel O'Connell and the Irish Party, 1830-1847. London: H. Hamilton, 1965.

Maclear, J.F. Church and State in the modern Age: A Documentary History. Oxford: Oxford University Press, 1995.

Mansergh, Nicholas. The Irish Question. London: George Allen and Unwin, 1965. 
Martinot, Steve. The Rule of Racialization: Class, Identity, Governance. Philadelphia: Temple University Press, 2003.

McClintock, Anne. Imperial Leather: Race, Gender, and Sexuality in the Colonial Context. London: Routledge, 1995.

McGee, Owen. The IRB: The Irish Republican Brotherhood from The Land League to Sinn Féin. Dublin: Four Courts Press, 2005.

Miles, Robert. Racism and Migrant Labour. London: Routledge, 1982.

Miller, Kerby A. Emigrants and Exiles: Ireland and the Irish Exodus to North America. Oxford: Oxford University Press, 1988.

Mokyr, Joel. Why Ireland Starved: A Quantitative and Analytical History of the Irish Economy, 1800-1850. London: George Allen and Unwin, 1983.

Muldoon, James. Identity on the Medieval Irish Frontier: Degenerate Englishmen, Wild Irishmen, Middle Nation. Florida: University of Florida Press, 2003.

Multi-Racist Britain, eds. Philip Cohen and Harwant S. Bains. London: Basingstoke, 1988.

Mytum, Harold. The Origins of Early Christian Ireland. London: Routledge, 1991.

Nationalist and Racist Movements in Britain and Germany Before 1914, eds. Paul Kennedy and Anthony Nicholls. Oxford: St. Anthony’s College Press, 1981.

Neal, Frank. Black '47 and the Famine Irish. New York: St. Martin’s Press, 1998.

A New History of Ireland, ed. W.E. Vaughan. 1989.

Nolan, Kevin. The Politics of Repeal: A Study in the Relations between Great Britain and Ireland, 1841-1850. London: Routledge, 1965.

Norman, Edward R. Anti-Catholicism in Victorian England. London: Allen \& Unwin, 1968.

O’ Brien, G. An Economic History of Ireland from the Union to the Famine. London, 1921.

O’ Farrell, Patrick. England and Ireland since 1800. London: Oxford University Press, 1975.

Ó Gráda, Cormac. Black '47 and Beyond: The Great Irish Famine in History, Economy and Memory. New Jersey: Princeton University Press, 2000. 
Ó Gráda, Cormac. Ireland Before and After the Famine: Explorations in Economic History, 1800-1925, Second Edition. England: Manchester University Press, 1993.

O’ Neill, Kevin. Family and Farm in Pre-Famine Ireland: The Parish of Killashandra. Wisconsin: University of Wisconsin Press, 2003.

O’Rourke, Canon John. A History of the Irish Famine of 1847, reprint. London: Bibliolife, 2008.

O’Sullivan, Patrick. The Irish World Wide: History, Heritage, Identity: Volume 6 The Meaning of the Famine. London: Leicester University Press, 1997.

"On Second Thought" and Other Essays in the History of Medicine and Science. Baltimore: John Hopkins University Press, 2001.

Paz, Denis G. Popular Anti-Catholicism in Mid-Victorian England (Stanford: Stanford University Press, 1992).

Peat, F. David. From Certainty to Uncertainty: The Story of Science and Ideas in the Twentieth Century. New York: Joseph Henry Press, 2002.

Pelling, Nick. Anglo-Irish Relations, 1798-1922. London: Routledge, 2003.

Read, David. Feargus O'Connor: Irishman and Chartist. London: Arnold, 1961.

Redford, Arthur. Labour Migration in England, 1800-1850. England: Manchester University Press, 1976.

Royle, Edward. Chartism. London: Longman, 1996.

Said, Edward. Culture and Imperialism. New York: Vintage, 1994.

Scally, Robert James. The End of the Hidden Ireland: Rebellion, Famine, and Emigration. Oxford: Oxford University Press, 1996.

Schonhardt-Bailey, C. From the Corn Laws to Free Trade: interests, ideas, and institutions in historical perspective. Cambridge: The MIT Press, 2006.

Shea, Victor and William Whitla, Essays and Reviews: The 1860 Text and its Readings. Virginia: University of Virginia Press, 2000.

Sloan, Robert. William Smith O'Brien and the Young Ireland Rebellion of 1848. Dublin: Four Courts Press, 2000. 
Smith, Anthony. Ethnic Origins of Nations. London: Wiley-Blackwell, 2009.

Stepan, Nancy. The Idea of Race in Science: Great Britain, 1800-1960. Connecticut: Archon Books, 1982.

Studies in Medieval and Renaissance History, IV, ed. J.A.S. Evans and R.W. Unger. Canada: University of British Columbia, 1983.

Swift, Roger. Irish Migrants in Britain, 1815-1914: A documentary history. Cork: Cork University Press, 2002.

Taylor, Barbara. Eve and the New Jerusalem. Socialism and Feminism in the Nineteenth Century. Harvard: Harvard University Press, 1993.

Thompson, E.P. The Making of the English Working Class. New York: Vintage, 1963.

Tóibín, Colm. The Irish Famine. London: Profile Books, 1999.

Tosh, John. Manliness and Masculinities in Nineteenth-Century Britain: Essays on Gender, Family and Empire. London: Pearson Longman, 2005.

Van Wyhe, John. Phrenology and the Origins of Victorian Scientific Naturalism. London: Ashgate Publishing, Ltd., 2004.

The Victorian and Race, ed. Shearer West. England: Scolar Press, 1996.

War and Society, ed. Michael R.D. Foot. New York: Barnes and Nobles Books, 1973.

Ward, Paul. Britishness Since 1870. London: Routledge, 2004.

Webber, Nick. The Evolution of Norman Identity, 911-1154. London: Boydell Press, 2005.

Williams, W. H. A. 'Twas only an Irishman's dream: the image of Ireland and the Irish in American popular song lyrics, 1800-1920. Illinois: University of Illinois Press, 1996.

Woodham-Smith, Cecil. The Great Hunger, 1845-9.London: Hamish Hamilton, 1962.

Woodward, E. L. The Age of Reform, 1815-1870. Oxford: Clarendon Press, 1962.

\section{John H. \\ Virginia University Libraries,
ou=Acquisitions Department,

